\title{
A SOUTHERN APPALACHIAN READER
}

\author{
Edited by \\ Nellie McNeil \\ छ \\ Joyce Squibb
}


A Southern Appalachian Reader 
This page intentionally left blank 


\section{A Southern Appalachian Reader}

Edited by Nellie McNeil and Joyce Squibb

Associate Editor: Rita Quillen

Appalachian Consortium Press, Boone, North Carolina 28608 


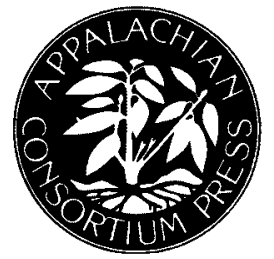

The Appalachian Consortium was a non-profit educational organization composed of institutions and agencies located in Southern Appalachia. From 1973 to 2004, its members published pioneering works in Appalachian studies documenting the history and cultural heritage of the region. The Appalachian Consortium Press was the first publisher devoted solely to the region and many of the works it published remain seminal in the field to this day.

With funding from the Andrew W. Mellon Foundation and the National Endowment for the Humanities through the Humanities Open Book Program, Appalachian State University has published new paperback and open access digital editions of works from the Appalachian Consortium Press.

www.collections.library.appstate.edu/appconsortiumbooks

This work is licensed under a Creative Commons BY-NC-ND license. To view a copy of the license, visit http://creativecommons.org/licenses.

Original copyright $(\mathcal{C} 1988$ by the Appalachian Consortium Press.

ISBN (pbk.: alk. Paper): 978-1-4696-4210-9

ISBN (ebook): 978-1-4696-4212-3

Distributed by the University of North Carolina Press

www.uncpress.org 


\section{Appalachian Consortium Press}

Boone, North Carolina

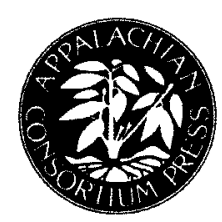

The Appalachian Consortium is a non-profit educational organization comprised of institutions and agencies located in the Southern Highlands. Founded in 1971, the initial objectives were to perpetuate, preserve, and promote the heritage of Southern Appalachia. Today the scope and diversity of the Consortium's objectives and activities have extended far beyond those upon which it was founded. Yet today it remains committed to one guiding principle-an improved quality of life for the people of the Southern Highlands.

Members of the Consortium are volunteers who plan and execute projects which primarily serve 156 mountain counties in seven states. They serve on eight standing committees (administration, editorial board, folklife, museum, regional collections, regional cooperation and development, regional education, and regional health services) which meet at various member locations throughout the service region. The administrative office of the Appalachian Consortium may be reached at (828) 262-2064 or (888) 557-8163.

Objectives of the Appalachian Consortium are:

*Preserving the cultural heritage of Southern Appalachia

*Protecting the mountain environment

*Publishing manuscripts about the region

*Improving educational opportunities for area students and teachers

*Conducting scientific, social, and economic research

*Promoting a positive image of Appalachia

*Encouraging regional cooperation

The members of the Appalachian Consortium are:

*Appalachian State University

*Blue Ridge Parkway

*East Tennessee State University

*Mission Children's Hospital

*Lees-McRae College

*Lincoln Memorial University

* Mars Hill College

*North Carolina Division of Archives and History

*Southern Highlands Craft Guild

*Department of Museum Program \& Studies-Tusculum College

*The University of Virginia's College at Wise

*U.S. Forest Service

*Warren Wilson College

*Western Carolina University 
This page intentionally left blank 
To Jack Higgs, our revered literature professor at East Tennessee State University, goes credit for this anthology. The contagion he, Tom Burton, and professors like them, created in their courses by introducing us to Appalachian literature caused us to design classes of our own. Then when we complained about the lack of a suitable text, Dr. Higgs responded, "Write one." His continued encouragement carried us to publication.

The Center for Appalachian Studies and Services and its director, Richard Blaustein, made publication possible.

We thank our editors, Rita Quillen and Mayrelee Newman, and our copy editor, Dale Winship.

We also thank Roberta Herrin, chair of the Appalachian Consortium publications committee, its members, and Jane Shook, Assistant Director for the Press, for their helpful support.

We thank Cindy Francisco who provided clerical assistance and Linda Fanslow and the late Clara Bennett who aided us in our research.

We send special thanks to Don Squibb, Joyce's husband, for going out for pizza. 
This page intentionally left blank 


\section{Table Of Contents}

Illustrations $\&$ Photos $\ldots \ldots \ldots \ldots \ldots \ldots \ldots \ldots \ldots \ldots \ldots \ldots, \ldots \ldots$

Introduction ..................................

Horace Kephart, Who Are the Mountaineers? . .......... xix

\section{THE PAST}

\section{CHAPTER 1}

Oral Tradition...3

Ballad of Claude Allen...$\ldots \ldots \ldots \ldots \ldots \ldots \ldots \ldots \ldots$

Richard Chase, Cat'n Mouse ......................8

Alice Marriott, Tsali of the Cherokees ................. 16

Cratis Williams, Dialect and Speech $\ldots \ldots \ldots \ldots \ldots \ldots \ldots \ldots .26$

Jean Ritchie, From Singing Family of the Cumberlands .......... 35

Carter Family Song, Single Girl, Married Girl ............. 55

Ballad of John Henry $\ldots \ldots \ldots \ldots \ldots \ldots \ldots \ldots \ldots \ldots . \ldots \ldots$

George Washington Harris, Old Skissism's Middle Boy . . . . . . 59

Composition Topics ............................66

Activities ..................................66 
x Table of Contents

\section{CHAPTER 2}

Local Color and Realistic Tradition ... 69

Mary Noailles Murfree, The Star in the Valley ...........71

John Fox, Jr., From A Cumberland Vendetta ............... 94

Anne Armstrong, From This Day and Time .............. 120

Mildred Haun, From The Hawk's Done Gone ............ 136

James Still, From River of Earth . . . . . . . . . . . . . . 155

Jesse Stuart, From Daughter of the Legend .............. 162

Composition Topics .............................. 174

Activities .................................. 174

\section{CHAPTER 3}

Contemporary Authors Search for a Usable Past . . 175

Thomas Wolfe, The Brother ....................... 176

James R. Stokely, Molly Mooneyham ................. 189

James Agee, From A Death in the Family ................ 194

Lee Smith, Saint Paul ......................... 209

Lou Crabtree, Homer-Snake . .................... 226

Eliot Wigginton, Ginseng from Foxfire $3 \ldots \ldots \ldots \ldots \ldots .236$

Bernard Stallard, The Writing Spider ................ 245

Ed Cabbell, Appalachia: An Old Man's Dream Deferred . . ... 247

Jim Wayne Miller, Beginning, Ending . ............... 252

Jeff Daniel Marion, Ebbing \& Flowing Spring . . . . . . . . . 254

Fred Chappell, My Grandmother Washes Her Vessels . . . . . . 257

Marilou Awiakta, Where Mountain and Atom Meet ........ 262

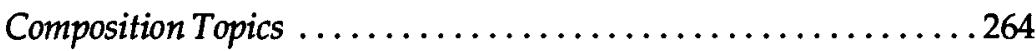

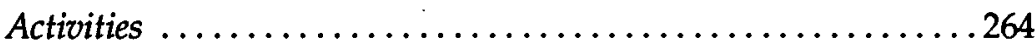




\section{THE PRESENT}

\section{CHAPTER 4}

How America Came to the Mountains . . 269

Alan Cheuse, Tripping the Lights Fantastic ............ 271

Victor Depta, TVA ......................... 277

Marilou Awiakta, Genesis . . . . . . . . . . . . . . . . . . . . 279

John Ehle, From The Road ....................283

Myles Horton, Building Democracy in the Mountains ....... 298

Composition Topics ..............................310

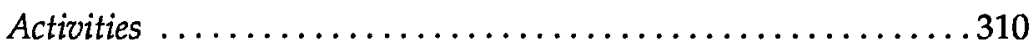

\section{CHAPTER 5}

Moving Mountains: The Struggle of the Coal Industry...313

Don West, Harlan Portraits . . . . . . . . . . . . . . . . 315

Nine Pound Hammer . . . . . . . . . . . . . . . . . . . 318

Harry Caudill, The Mountain, the Miner, and the Lord . ......320

Ron Short, From South of the Mountain ................ 337

George Ella Lyon, Stripped . ...................... 347

Lee Howard, The Last Unmined Vein ................. 349

Edwin Hoffman, Strippers, No! . . . . . . . . . . . . . . . . 352

Richard Hague, In the Woods Beyond the Coalfields ........375

Composition Topics ............................. 378

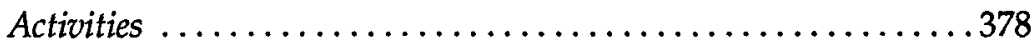


xii Table of Contents

\section{CHAPTER 6}

The Change Hits Home . . . 379

Jesse Stuart, Split Cherry Tree $\ldots \ldots \ldots \ldots \ldots \ldots \ldots \ldots \ldots . \ldots . \ldots 1$

Fred Chappell, Firewater . . . . . . . . . . . . . . . . . . . 397

Wilma Dykeman, From Return the Innocent Earth ..........402 Jim Wayne Miller,

The Brier Losing Touch With His Traditions .............418

Katherine Stripling Byer, Wide Open, These Gates .........421

Composition Topics ............................423

Activities ................................423

\section{CHAPTER 7}

Appalachian Emigration . . .425

Robert Morgan, Bean Money $\ldots \ldots \ldots \ldots \ldots \ldots \ldots \ldots \ldots 427$

Bobbie Ann Mason, Nancy Culpepper ................431

Jim Wayne Miller, Turn Your Radio On ..................449

Borden Deal, Antaeus $\ldots \ldots \ldots \ldots \ldots \ldots \ldots \ldots \ldots \ldots \ldots . \ldots 452$

Jo Carson, My Brother Estes . . .................... 465

Gurney Norman, A Correspondence ..................468

Robert Penn Warren, Sitting on Farm Lawn

on Sunday Afternoon ..........................476

Lisa Alther, From Kinflicks ......................479

Composition Topics .............................485

Activities ...................................485 
TABLE OF CONTENTS Xiii

\section{CHAPTER 8}

The Sense of Place in Appalachian Writing . . 487

Wendell Berry, The Strangers ...................... 489

Herman Hascal Giles, Man of the Land ............... 492

Judy Odom, The Killing Jar ...................... 500

Rita Quillen, The Good Life $. . . \ldots \ldots \ldots \ldots \ldots \ldots . \ldots . \ldots 14$

James Still, Heritage .......................... 517

Composition Topics ............................... 519

Activities ...................................... 519

Acknowledgments ............................5523

Suggested Bibliography .........................527 
This page intentionally left blank 


\section{Illustrations $\mathcal{E}$ Photos}

Cover illustration by Kenneth Murray

1. Courtesy of Archives of Appalachia, East Tennessee State University

2. Illustration by Sharon Squibb

3. Courtesy of Archives of Appalachia, East Tennessee State Univesity

4. Illustration by Harrison Cady, courtesy of Art and Architecture Gallery, University of Tennessee

5. Photograph by Joe Clark

6. Courtesy of Tennessee Eastman Company

7. Photograph by Eddie Le Sueur

8. Photograph by Eddie Le Sueur

9. Courtesy of Archives of Appalachia, East Tennessee State University

10. Photograph by Chris Jones

11. Photograph by Chris Jones 
This page intentionally left blank 


\section{Introduction}

Over the past decade, the study of Appalachian literature has blossomed with workshops, conferences, and summer institutes for teachers cropping up throughout the region. Many educators in Appalachia seem eager to introduce their students to the literary heritage of Appalachia. One problem, however, has prevented teachers from instituting full-fledged Appalachian literature courses, particularly at the high school level. The problem has been lack of a textbook. We hope $A$ Southern Appalachian Reader will fill that void.

This book is divided into two sections. Section I focuses on the past and moves from the oral tradition of ballads and storytelling to "local color" and modern realism that focused national attention on Appalachia. Pieces by contemporary writers like Lee Smith and Jim Wayne Miller are included and show the strong tendency to cast a backward glance, to reminisce.

Section II deals with the present and shows the impact regional institutions such as the Tennessee Valley Authority, the Appalachian Regional Commission and the Highlander Research Center have had on Appalachia. Chapter Seven explores the phenomenon of Appalachian emigration: the flight of mountain people to large urban areas in search of a better life. Finally, this collection ends on the road home. A strong sense of belonging to a place, to its land and its people, is the focus of the last selections. All of Section II challenges 
students to think about the result of rapid change in the life of the individual and on regional culture as a whole.

For most students, this will serve as a comprehensive introduction to the Appalachian region's history and literature. We have included as many writers as possible to give some overview of the richness of the region's past. Most of all, this textbook is intended to help students value the region's heritage and traditions. This appreciation will help students, whether they are native Appalachians or not, to gain a deeper understanding of themselves and the forces that shape regional life.

The study of literature often makes people think about themselves. Regional literature, particularly, makes a person even more conscious of behavior, beliefs, and other life patterns. As the poet and scholar Dr. Jim Wayne Miller says:

We should be concerned with teaching the history and culture of our different regions not for the past's sake, but for the sake of the present and future.... Such view counters the rootless uniformity of popular culture with the realization of rooted diversity.

Each student should finish this book with increased knowledge and understanding not only of the literature, but also of himself and his family. By including discussion questions, composition topics, suggestions for out-of-class activities, and lists of additional materials, we hope to inspire students toward self-knowledge. As a person comes to value himself, he or she values others-another aim of this book.

The Appalachian region is broad and rapidly changing. The startling demands of the future will be met more effectively by those with a strong sense of history and a sense of responsibility to the land and its people. We hope $A$ Southern Appalachian Reader will be a starting point for deeper study and will encourage the student's lifelong interest in and concern for one of America's most fascinating regions. 
HORACE KEPHART $\quad x i x$

HORACE KEPHART (1862-1931)

Horace Kephart came from Pennsylvania to the Southern Appalachian Mountains in 1904. He was an avid naturalist who played an important role in the founding of the Great Smoky Mountain National Park and the Appalachian Trail.

His published works include: Camping and Woodcraft, Camping, The Camper's Manual, and Our Southern Highlanders.

During the more than sixty years since Our Southern Highlanders was published, it has been recognized as one of the most important studies of Appalachians. Few other books on this subject are more widely known or cited. It is the source for the following selection.

Who Are The Mountaineers?

The Southern Appalachian Mountains happen to be parceled out among eight different States, and for that reason they are seldom considered as a geographical unit. In the same way their inhabitants are thought of as Kentucky mountaineers or Carolina mountaineers, and so on, but not often as a body of Appalachian mountaineers. And yet these inhabitants are as distinct an ethnographic group as the mountains themselves are a geographic group.

The mountaineers are homogeneous so far as speech and 
manners and experiences and ideals can make them. In the aggregate they are nearly twice as numerous and cover twice as much territory as any one of the States among which they have been distributed; but in each of these States they occupy only the backyard, and generally take back seats in the councils of the commonwealth. They have been fenced off from each other by political boundaries and have no such coherence among themselves as would come from common leadership or a sense of common origin and mutual dependence.

And they are people without annals. Back of their grandfathers they have neither screed nor hearsay. "Borned in the kentry and ain't never been out $o^{\prime}$ ' hit" is all that most of them can say for themselves. Here and there one will assert, "My foreparents war principally Scotch," or "Us Bumgyarners [Baumgartners] was Dutch," but such traditions of a far-back foreign origin are uncommon.

Who are these southern mountaineers? Whence came they? What is the secret of their belatedness and isolation?...

The first frontiersmen of the Appalachians were those Swiss and Palatine Germans who began flocking into Pennsylvania about 1682 . They settled westward of the Quakers in the fertile limestone belts at the foot of the Blue Ridge and the Alleghanies. Here they formed the Quakers' buffer against the Indians, and, for some time, theirs were the westernmost settlements of British subjects in America. These Germans were of the Reformed or Lutheran faith. They were strongly democratic in a social sense, and detested slavery. They were model farmers and many of them were skilled workmen at trades.

Shortly after the tide of German immigration set into Pennsylvania, another and quite different class of foreigners began to arrive in this province, attracted hither by the same lodestones that drew the Germans, namely, democratic institutions and religious liberty. These newcomers were the ScotchIrish, or Ulstermen of Ireland.

When James I., in 1607, confiscated the estates of the native Irish in six counties of Ulster, he planted them with Scotch and 
English Presbyterians. These outsiders came to be known as Scotch-Irish, because they were chiefly of Scotch blood and had settled in Ireland. The native Irish, to whom they were alien both by blood and by religion, detested them as usurpers, and fought them many a bloody battle.

In time, as their leases in Ulster began to expire, the ScotchIrish themselves came in conflict with the Crown, by whom they were persecuted and evicted. Then the Ulstermen began immigrating in large numbers to Pennsylvania. As Froude says, "In the two years that followed the Antrim evictions, thirty thousand Protestants left Ulster for a land where there was no legal robbery, and where those who sowed the seed could reap the harvest."

So it was that these people became, in their turn, our westernmost frontiersmen, taking up land just outside the German settlements. Immediately they began to clash with the Indians, and there followed a long series of border wars, waged with extreme ferocity, in which sometimes it is hard to say which side was most to blame. One thing, however, is certain: if any race was ordained to exterminate the Indians that race was the Scotch-Irish.

They were a brave but hot-headed folk, as might be expected of a people who for a century had been planted amid hostile Hibernians. Justin Winsor describes them as having "all that excitable character which goes with a keen-minded adherence to original sin, total depravity, predestination, and election," and as seeing "no use in an Indian but to be a target for their bullets." They were quick-witted as well as quicktempered, rather visionary, imperious and aggressive.

Being by tradition and habit a border people, the ScotchIrish pushed to the extreme western fringe of settlement amid the Alleghanies....

West of the Susquehanna, however, the land was so rocky and poor that even the Scotch shied at it, and so when eastern Pennsylvania became crowded, the overflow of settlers passed not westward but southwestward, along the Cumberland Valley, into Western Maryland, and then into the Shenandoah and 
those other long, narrow, parallel valleys of western Virginia. This western region still lay unoccupied and scarcely known by the Virginians themselves. Its fertile lands were discovered by Pennsylvania Dutchmen. The first house in western Virginia was erected by one of them, Joist Hite, and he established a colony of his people near the future site of Winchester. A majority of those who settled in the eastern part of the Shenandoah Valley were Pennsylvania Dutch, while the Scotch-Irish, following in their train, pushed a little to the west of them and occupied more exposed positions. There were representatives of other races along the border: English, Irish, French Huguenots, and so on; but everywhere the Scotch-Irish and Germans predominated.

And the southwestward movement, once started, never stopped. So there went on a gradual but sure progress of northern peoples across the Potomac, up theStaunton, the Dan, the Yadkin, until the western piedmont and foot-hill region of Carolina was similarly settled, chiefly by Pennsylvanians.

The archivist of North Carolina, the late William L. Saunders, Secretary of State, said in one of his historical sketches that "to Lancaster and York counties, in Pennsylvania, North Carolina owes more of her population than to any other known part of the world." He called attention to the interesting fact that when the North Carolina boys of Scotch-Irish and Pennsylvania Dutch descent followed Lee into Pennsylvania in the Gettysburg campaign, they were returning to the homes of their ancestors, by precisely the same route that those ancestors had taken in going south.

Among those who made the long trek from Pennsylvania southward in the eighteenth century, were Daniel Boone and the ancestors of David Crockett, Samuel Houston, John C. Calhoun, "Stonewall" Jackson, and Abraham Lincoln. Boone and the Lincolns, although English themselves, had been neighbors in Berks County, one of the most German parts of all eastern Pennsylvania.

So the western piedmont and the mountains were settled neither by Cavaliers nor by poor whites, but by a radically dis- 
tinct and even antagonistic people who are appropriately called the Roundheads of the South. These Roundheads had little or nothing to do with slavery, detested the state church, loathed tithes, and distrusted all authority save that of conspicuous merit and natural justice. The first characteristic that these pioneers developed was an intense individualism. The strong and even violent independence that made them forsake all the comforts of civilization and prefer the wild freedom of the border was fanned at times into turbulence and riot; but it blazed forth at a happy time for this country when our liberties were imperilled.

Daniel Boone first appears in history when, from his new home on the Yadkin, he crossed the Blue Ridge and the Unakas into that part of western Carolina which is now eastern Tennessee. He was exploring the Watauga region as early as 1760 . Both British and French Indian traders and soldiers had been in this region before him, but had left few marks of their wanderings. In 1761 a party of hunters from Pennsylvania and contiguous counties of Virginia, piloted by Boone, began to use this region as a hunting-ground, on account of the great abundance of game. From them, and especially from Boone, the fame of its attractions spread to the settlements on the eastern slope of the mountains, and in the winter of 1768-69 the first permanent occupation of eastern Tennessee was made by a few families from North Carolina.

About this time there broke out in Carolina a struggle between the independent settlers of the piedmont and the rich trading and official class of the coast. The former rose in bodies under the name of Regulators and a battle followed in which they were defeated. To escape from the persecution of the aristocracy, many of the Regulators and their friends crossed the Appalachian Mountains and built their cabins in the Watauga region. Here, in 1772, there was established by these "rebels" the first republic in America, based upon a written constitution "the first ever adopted by a community of American-born freemen." Of these pioneers in "The Winning of the West," Theodore Roosevelt says: "As in western Virginia the first set- 
tlers came, for the most part, from Pennsylvania, so, in turn, in what was then western North Carolina, and is now eastern Tennessee, the first settlers came mainly from Virginia, and indeed, in great part, from this same Pennsylvania stock."

Boone first visited Kentucky, on a hunting trip, in 1769. Six years later he began to colonize it, in flat defiance of the British government, and in the face of a menacing proclamation from the royal governor of North Carolina. On the Kentucky River, three days after the battle of Lexington, the flag of the new colony of Transylvania was run up on his fort at Boonesborough. It was not until the following August that these "rebels of Kentuck" heard of the signing of the Declaration of Independence, and celebrated it with shrill warwhoops around a bonfire in the center of their stockade.

Such was the stuff of which the Appalachian frontiersmen were made. They were the first Americans to cut loose entirely from the seaboard and fall back upon their own resources. They were the first to establish governments of their own, in defiance of king and aristocracy. Says John Fiske:

Jefferson is often called the father of modern American democracy; in a certain sense the Shenandoah Valley and adjacent Appalachian regions may be called its cradle. In that rude frontier society, life assumed many new aspects, old customs were forgotten, old distinctions abolished, social equality acquired even more importance than unchecked individualism. The notions, sometimes crude and noxious, sometimes just and wholesome, which characterized Jeffersonian democracy, flourished greatly on the frontier and have thence been propagated eastward through the older communities, affecting their legislation and their politics more or less according to frequency of contact and intercourse. Massachusetts, relatively remote and relatively ancient, has been perhaps least affected by this group of ideas, but all parts of the United States have felt its influence powerfully. This phase of democracy, which is destined to continue so long as frontier life retains any importance, can nowhere be so well studied in its beginnings as among the 
Presbyterian population of the Appalachian region in the 18 th century.

During the Revolution, the Appalachian frontier was held by a double line of the men whom we have been considering: one line east of the mountains, and the other west of them. The mountain region itself remained almost uninhabited by whites, because the pioneers who crossed it were seeking better hunting grounds and farmsteads than the mountains afforded. It was not until the buffalo and elk and beaver had been driven out of Tennessee and Kentucky, and those rolling savannahs were being fenced and tilled, that much attention was given to the mountains proper. Then small companies of hunters and trappers from both east and west began to move into the highlands and settle there.

These explorers, pushing outward from the cross-mountain trails in every direction, found many interesting things that had been overlooked in the scurry of migration westward. They discovered fair river valleys and rich coves, adapted to tillage, which soon attracted settlers of a better class; and so, gradually, the mountain solitudes began to echo with the ring of axes and the lowing of herds. By 1830 about a million permanent settlers occupied the southern Appalachians. Naturally, most of them came from adjoining regions-from the foot of the Blue Ridge on one side and from the foot of the Unakas or of the Cumberlands on the other, and hence they were chiefly of the same frontier stock that we have been describing. No colonies of farmers from a distance ever have been imported into the mountains, down to our own day.

Deterioration of the mountain people began as soon as population began to press upon the limits of subsistence. At first, naturally, the best people among the mountaineers were attracted to the best lands. But the number and extent of such valleys was narrowly limited. The United States topographers report that in Appalachia, as a whole, the mountain slopes oc- 
cupy 90 percent of the total area, and that 85 percent of the land has a steeper slope than one foot in five. So, as the years passed, a larger and larger proportion of the highlanders was forced back along the creek branches and up along the steep hillsides to "scrabble" for a living.

It will be asked, Why did not this overplus do as other crowded Americans did: move west?

First, because they were so immured in the mountains, so utterly cut off from communication with the outer world, that they did not know anything about the opportunities offered new settlers in far-away lands. Moving "west" to them would have meant merely going a few days' wagon-travel down into the lowlands of Kentucky or Tennessee, which already were thickly settled by a people of very different social class. Here they could not hope to be anything but tenants or menials, ruled over by proprietors or bosses-and they would die rather than endure such treatment. As for the new lands of the farther West, there was scarce a peasant in Ireland or in Scandinavia but knew more about them than did the southern mountaineers.

Second, because they were passionately attached to their homes and kindred, to their own old-fashioned ways. The mountaineer shrinks from lowland society as he does from the water and the climate of such regions. He is never at ease until back with his home-folks, foot-loose and free.

Third, because there was nothing in his environment to arouse ambition. The hard, hopeless life of the mountain farm, sustained only by a meager and ill-cooked diet, begat laziness and shiftless unconcern.

Finally, the poverty of the hillside farmers and branchwater people was so extreme that they could not gather funds to emigrate with. There were no industries to which a man might turn and earn ready money, no markets in which he could sell a surplus from the farm.

So, while the transmontane settlers grew rapidly in wealth and culture, their kinsfolk back in the mountains either stood still or retrograded, and the contrast was due not nearly so 
much to any difference of capacity as to a law of Nature that dooms an isolated and impoverished people to deterioration.

So the southern highlanders languished in isolation, sunk in a Rip Van Winkle sleep, until aroused by the thunder-crash of the Civil War. Let John Fox tell the extraordinary result of that awakening.-

The American mountaineer was discovered, I say, at the beginning of the war, when the Confederate leaders were counting on the presumption that Mason and Dixon's Line was the dividing line between the North and South, and formed, therefore, the plan of marching an army from Wheeling, in West Virginia, to some point on the Lakes, and thus dissevering the North at one blow.

The plan seemed so feasible that it is said to have materially aided the sale of Confederate bonds in England. But when Captain Garnett, a West Point graduate, started to carry it out, he got no farther than Harper's Ferry. When he struck the mountains, he struck enemies who shot at his men from ambush, cut down bridges before him, carried the news of his march to the Federals, and Garnett himself fell with a bullet from a mountaineer's squirrel rifle at Harper's Ferry.

Then the South began to realize what a long, lean, powerful arm of the Union it was that the southern mountaineer stretched through its very vitals; for that arm helped hold Kentucky in the Union by giving preponderance to the Union sympathizers in the Blue-grass; it kept the east Tennesseans loyal to the man; it made West Virginia, as the phrase goes, 'secede from secession'; it drew out a horde of one hundred thousand volunteers, when Lincoln called for troops, depleting Jackson County, Kentucky, for instance, of every male under sixty years of age and over fifteen; and it raised a hostile barrier between the armies of the coast and the armies of the Mississippi. The North has never realized, perhaps, what it owes for its victory to this non-slaveholding southern mountaineer.

It may be added that no other part of our country suffered 
longer or more severely from the aftermath of war. Throughout that struggle the mountain region was a nest for bushwhackers and bandits that preyed upon the aged and defenseless who were left at home, and thus there was left an evil legacy of neighborhood wrongs and private grudges. Most of the mountain counties had incurred the bitter hostility of their own States by standing loyal to the Union. After Appomattox they were cast back into a worse isolation than they had ever known.

Left, then, to their own devices, unchecked by any stronger arm, inflamed by a multitude of personal wrongs, habituated to the shedding of human blood, contemptuous of State laws that did not reach them, enraged by Federal acts that impugned, as they thought, an inalienable right of man, it was inevitable that this fiery and vindictive race should fall speedily into warring among themselves. Old scores were now to be wiped out in a reign of terror. The open combat of bannered war was turned into the secret ferocity of family feuds.

But the mountaineers of today are faced with a mighty change. The feud epoch has ceased throughout the greater part of Appalachia. A new era dawns. Everywhere the highways of civilization are pushing into remote mountain fastnesses. Vast enterprises are being installed. The timber and the minerals are being garnered. The mighty waterpower that has been running to waste since these mountains rose from the primal sea is now about to be harnessed in the service of man. Along with this economic revolution will come, inevitably, good schools, newspapers, a finer and more liberal social life. The highlander, at last, is to be caught up in the current of human progress.

\section{Who Are the Mountaineers?}

1. Who were the first frontiersmen to settle in Appalachia? Where did they settle? 
2. Who were the Scotch-Irish? What was their reason for coming to America?

3. What qualities did the Scotch-Irish possess that made them successful settlers in Appalachia? 
xxx Who Are The Mountaineers?

Illustration No. 1

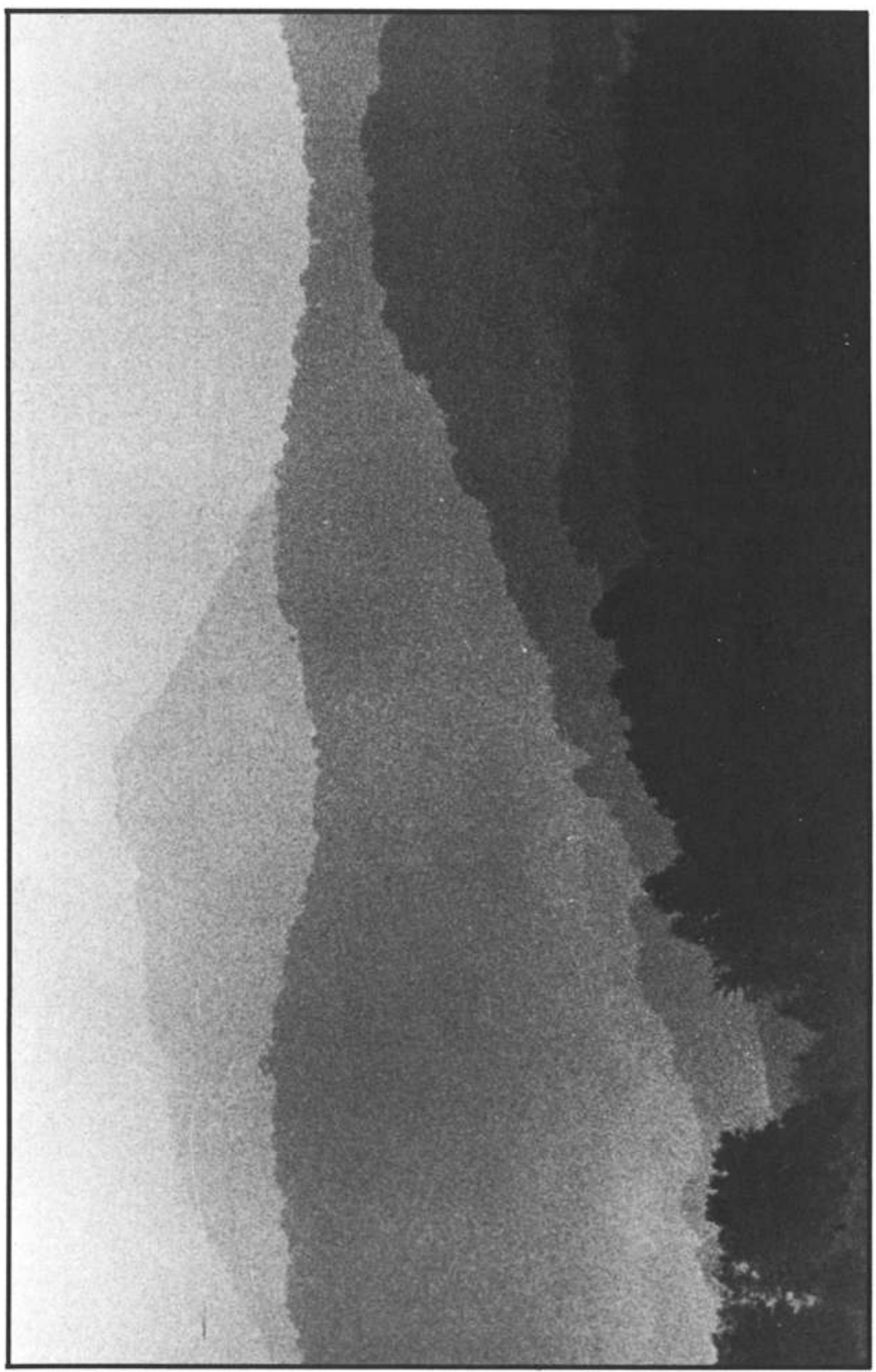


This page intentionally left blank 
PART I

The Past 
This page intentionally left blank 


\section{CHAPTER 1 \\ Oral Tradition}

Appalachian literature is founded on oral tradition. Ballads and storytelling came to these mountains with the first settlers, were passed down from generation to generation, and today are more popular than ever.

Ballads, one of the earliest forms of poetry, date back to the Middle Ages. A ballad is simply a story in song. The ballad draws from many sources: legend and folklore, local and national history, and from the singer's own community. Although some ballads are humorous, most tend to be tragic and tell stories of war, destruction, lost love, or supernatural occurrences. "The Ballad of Claude Allen" depicts a tragedy of everyday life.

Although many folklorists had collected ballads, A.P. Carter of Southwest Virginia was the first to record them commercially. This "hillbilly" music, as it is often called has become the foundation of the country music industry. Like music, story telling has a rich literary tradition in the mountains of Appalachia. The practice of passing down family stories is apparent in the selection by Jean Ritchie. Sut 
Lovingoods's Yarns by George Washington Harris come from the oral tradition and are highly crafted pieces of fiction. 


\section{BALLAD OF CLAUDE ALLEN}

This ballad tells the story of the execution of Claude Allen and his father Floyd in Hillsville, Virginia, in 1913. Claude was attending the trial of his father, who had been charged for assaulting a deputy and sentenced to a year in prison.

When Floyd's lawyer rose to ask for a retrial, the judge consented. At that time Claude went up to speak to his father. Within minutes many people, including Claude, Floyd, and his brotherSidna, began firing their guns. It was not clear who had fired the first shot. The sheriff, prosecuting attorney, and judge were all killed.

Both Floyd and Claude were tried and sentenced to die in the electric chair. Before the execution, Claude was presented a gold medal by the women of Virginia inscribed: "For bravery in defending his father."

Note: This tune is that of the song commonly known as "Wayfaring Stranger."

High up on yonder's lovely mountain

Claude Allen lays beneath the clay;

No more we hear his words of mercy

Or see his face till Judgment Day. 

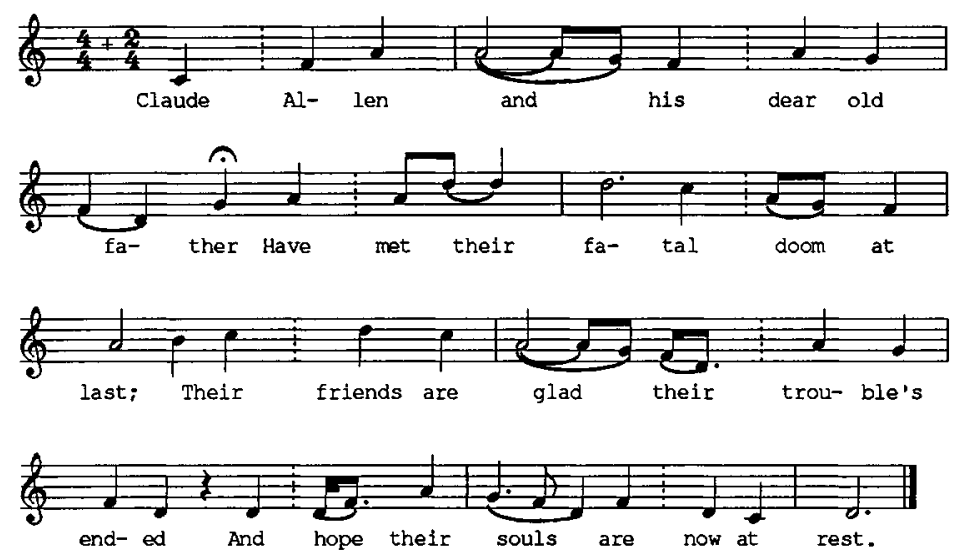

1. Claude Allen and his dear old father Have met their fatal doom at last; Their friends are glad their trouble's ended And hope their souls are now at rest.

2. Poor Claude was young and very handsome And still had hopes until the end That he might in some way or other Escape his death at the Richmond's pen.

3. But the governor, being so hard-hearted, Not caring what his friends might say, He finally took his sweet life from him; In the cold ground his body lay.

4. Claude's mother's tears were gently flowing, All for the one she loved so dear. It seemed no one could tell her troubles; It seemed no one could tell but her. 
5. Poor Claude, he had a pretty sweetheart; She mourns the loss of the one she loved. She hopes to meet beyond the river, A fair young face in heaven above.

6. Now, all young men, from this take warning; Be careful how you go astray, Or you might be like poor Claude Allen And have this awful debt to pay.

\section{The Ballad of Claude Allen}

1. As you read this ballad, with whom do you sympathize? How do the words of the song influence your feelings?

2. Find a clue in the song that shows how the people of Virginia felt about the execution of Claude and Floyd. 
RICHARD CHASE (1904-1988)

Born in North Alabama near Huntsville, Richard Chase received his B.A. from Antioch College in 1929. He lectured on folklore and told tales in schools, colleges, and universities throughout the United States. He founded an Appalachian craft industry and conducted folk art workshops.

He edited a number of collections of folk songs and folk tales for publication. Among these are the "Jack Tales" for which he is best known. These tales, many of which probably came from northwestern Europe, have been handed down orally from generation to generation, and have undergone many variations over the years.

This story may remind readers of other tales about witches and haunted houses.

\section{Cat'n Mouse}

One time the boys' daddy decided he'd give'em a hundred dollars a-piece and let 'em go out by themselves to see what would they do with it. Told 'em to be gone one year and then to come back so he could see which one of 'em made the best out of his money.

Well, the three of 'em set out together down the big road. Then Will says, "Now, when we come to where the road forks 
three ways, we'll separate. There ain't no use in us goin' all together."

So when they came to a crossroad, they stopped and talked awhile, and directly Will called Tom off to one side and they went to whisperin', then they both came over to Jack and throwed him down and took every cent of his money, divided it, and left Jack a-layin' there. Will took one side-road and Tom took the other'n. Jack got his senses back pretty soon and set there a little while tryin' to study what to do. Then he decided he'd go on and see what luck he might have, so he walked out in the middle of the crossroads and throwed his hat up in the air. Whichever road it landed in, he was goin' to go that way. Well, his hat landed in the road straight ahead, so he took it and on he went.

Hit was an old road, not traveled much, and pretty soon Jack landed 'way out in a lonesome wilder-ness of a place. Went on, went on; the road pretty nearly covered up with grass and briars, and directly he came to a fine-lookin' white house out there. Jack could see signs of somebody livin' there and he had to have some place to stay the night. He hated to holler 'cause he was so ragged and dirty, but he 'lowed there wasn't nothin' like tryin', so he hollered hello and waited awhile. Nobody came out, so he went to the door and pulled the doorbell. The door opened and a big cat came out. Jack didn't know what to think of that. The cat sat there looking at him and there didn't no person come to the door, so Jack hollered again, "Who keeps the house?"

"Cat 'n mouse," says the cat.

"Law me!" says Jack. "I've done got to a country where cats can talk."

"Yes," the cat told him, "there's an old witch out here. She got all my family but me and my sister. She witched her into a cat, then to a mouse, and me into a cat. She'll try to witch me into a mouse tonight."

Then Jack looked and saw a mouse creep out one side the door, says, "Well, is there anything I can do to keep the old witch from botherin' ye?" 
"Probably might be," says the cat. "You can help me, but my sister, she'll stay a mouse. There can't be nothin' done for ye, once she gets you into a mouse. You stay here by the door tonight and kill any kind of big varmints you see and it'll keep the witch off."

Well, Jack got him a big club and got before the door, and when it got plumb thick dark all sorts of bears and painters and big wild animals came up the steps and Jack'uld knock'em and beat 'em with his club, kept on fightin' all night. Next mornin' that cat came out and it was a little bigger, looked a little bit like a girl.

"Now tonight," she says, "the old witch'll send middle-size varmints. You see can you keep them off, too."

Jack picked around that day and got what berries and such he could find to eat, cut him a middle-size club and when it commenced gettin'dark he got by the door again. Then all kinds of pizen snakes and wildcats and weasels and boomers and ground hogs came and tried to get in. Jack hit at 'em with his club and knocked 'em off the porch and kept on a-givin' it to 'em till daylight. Then the door opened and that girl came out. She was pretty near the right size that time, but she still had some signs of a cat's claws and whiskers and ears.

She says to Jack, "You done fine last night, Jack. Now tonight she'll send all sorts of little varmints. You'll have a time of it, I expect."

So Jack eat a few blackberries and huckleberries that day and whittled him out some paddles and swatters and took up his stand by the door when night came; and all sorts of pizen scorpions and insects and spiders and hornets and big ants came up and tried to cross the door sill, but Jack went to work with his swatters and his paddles and it was a sight in the world how he went after 'em. He thought there'd be a pile of dead things there when it got daylight, but when it got light enough for him to see, there wasn't a thing there on the porch.

Then the door opened and there stood the prettiest girl you ever looked at.

"You did real well, Jack," she says. "You come on in the 
house now and I'll fix ye somethin' to eat."

She baked Jack some cornbread and fixed him some coffee, and while he was eatin', she says to him, "Now, you won't have nothin' to contend with tonight but the old witch herself. You got shet of all the plagues she had. Now, when she comes in you be sure and not let her do anything in the world for ye. I'll hide, and you and the old witch can go to it. You remember now, if you let her do one thing for ye, she'll witch us both into cats."

So that night that girl went and hid somewhere, and Jack he found him a needle and some thread, pulled up 'fore the fire and went to patchin' his old raggedy coat. It wasn't long till a little ugly wrinkled-up woman came hobblin' in the door, looked like she was about a hundred years old. Her nose and her chin was so long they hung down a-wobblin'. She got a chair and pulled up close to Jack, says, "Howdy do, Jack."

"Howdy do, ma'm."

"Let me do that for ye, Jack. It looks awkward seein' a man try to patch."

"No," says Jack, "I'll do my own patchin'."

The old witch looked sort of out-done, but Jack kept right on, and directly he got up to fix him a little supper. Got some meal and a pan and started mixin' bread."

"Let me do that for ye, Jack. I never did like to see a man try to make bread."

"No," says Jack, "I can fix bread all right."

Then he went to the fire, raked him out some coals and set the skillet over 'em. Then he cut some meat and started it to fryin'.

"Let me'tend the meat for ye, Jack. I never saw anything so awkward as a man tryin' to cook."

"No, thank you, ma'm," says Jack, "I don't want you messin' with my meat. I'll tend it myself."

Well, when Jack turned around to get his bread that old witch got hold of the knife and went to turn Jack's meat over. There was an old flesh fork a-hangin' there, big old fork they used to cook meat on. Jack grabbed that up and ran at the old 
woman with it, hooked her and rammed her right on in the fire. He held her down between the backlog and the forestick and such a crackin' and a poppin' and a fryin'and a singein' you never heard. Jack kept her there until she burnt up.

Then there stood that girl just a-laughin', says, "You sure got her then, Jack. There'll be no more witchery done around here."

So she fixed Jack a nice supper and the next mornin' when they went out that place was just full of fine livestock-chickens and hogs and sheep and cattle and horses-and the road was cleared out and the crops all standin' in the fields.

That girl says to Jack, "Ever'thing here belongs to you now, Jack, for killin' that witch."

"You too?" says Jack.

"Well," she says, "yes; if you say so."

"I'll sure say so," says Jack; "you're the main part of the property."

So they went and got two fine horses and hitched 'em up to the surrey, and went to the store and got Jack a new suit of clothes and then found 'em a preacher and got married. Jack he went to work about the place tendin' to his crops and his livestock, and that young woman she cooked and did the washin' and the milkin' and churnin' and all; and then Jack got to studyin' how the year was about up. So he told the girl about how he and Will and Tom had started out, and said they'd better fix up pretty soon to go back to see his daddy.

So they got ready and pulled out with the team and buggy one mornin'. Jack had got his old clothes and throwed 'em in under the seat. That girl had a pet fox and they took it along too.

They came in sight of Jack's house and he said to her, "You wait here a minute. I want to see what all's done happened while I been gone, see if Will and Tom got back yet."

Then he put on his raggedy old clothes, put that fox under his arm and went on to the house.

His father saw him comin' and came out to the gate, says, "Hello, Jack. Glad to see ye. You look like you must not 'a had 
any luck; I see you got the same suit of clothes."

"Will and Tom come?" Jack asked him.

"Yes, they got in early this mornin'. They got new clothes and both of them married nice-lookin' women. You wait here, Jack, and let me go get you one of my suits of clothes so you'll have somethin' better to wear when you come in."

"No," Jack told him, "I'll just go ahead like I am."

So he went into the house, and when Will and Tom saw him in his same ragged overhalls and coat, they com-menced laughin' and makin' fun of him; and their wives they slipped around and pinned dishrags to his coat-tails. Jack didn't pay no mind. He talked to his daddy and his mother awhile. Ever' now and then he'd squeeze down on that fox and it 'uld say,

"Gold enough

But none for you."

Will and Tom they couldn't understand that. Then directly Jack went on back where he'd left his wife. He got his good new suit of clothes on again and then him and his wife drove the surrey on down to the gate. Hitched the horse and Jack took the pet fox under his arm.

Will looked out and saw'em, says, "Who's that?"

Tom came and looked. "Ain't nobody we know. It's rich folks. What you reckon they want?"

Their wives, they came and peeked around the door. And about that time Jack's mother looked out the window, and says, "That's Jack."

"No!" says Will. "Why, that can't be Jack."

"Yes, it is, too," says Tom. "It is Jack, and look what a pretty fine-dressed woman he's got."

"Law me!" says Will's wife, "hit'll not do for her to see the way I am." And she ran and hid under the bed.

Then Tom gave his wife a shove, says, "You run hide somewhere quick. Don't let her see you in that old cotton dress." And she jumped off the porch and crawled in under the house.

Jack brought his wife on in and made her known to his daddy and his mother, and Will and Tom just stood around.

Fin'ly Jack's wife said to 'em, "I thought Jack told me you 
boys was married. Where's your wives at?"

"Mine's under the bed," says Will. "She can come out if she wants to."

She crawled out from under the bed, had feathers and dust in her hair. Then Jack's woman asked if the other'n was home, and Tom's wife she scrambled out from under the floor with her hair full of trash and dirt all over her. Jack's wife spoke nice to 'em, and they all talked awhile. Jack squeezed down on that fox directly and it said,

"Gold enough

But none for you.

And by that time Will and Tom knowed what it meant.

Well, Jack took his daddy and his mother back with him and his wife, and they was all independent rich. Will and Tom never did do much good. And Jack and his wife and his folks they lived happy.

\section{Cat'n Mouse}

1. What happenings in this story remind you of tales you've read or heard before?

2. What advice did the cat give Jack before he met the witch? Did Jack follow the advice? What was the result?

3. The uncommon events in fairy tales often satisfy our own dreams and desires. Is this true in the story "Cat n' Mouse"? Explain.

4. According to Cratis Williams, mountain dialect often contains words with the final $g$ left off, as in goin', workin', and doin'. Find words in the story which fit this pattern. 
Illustration No. 2

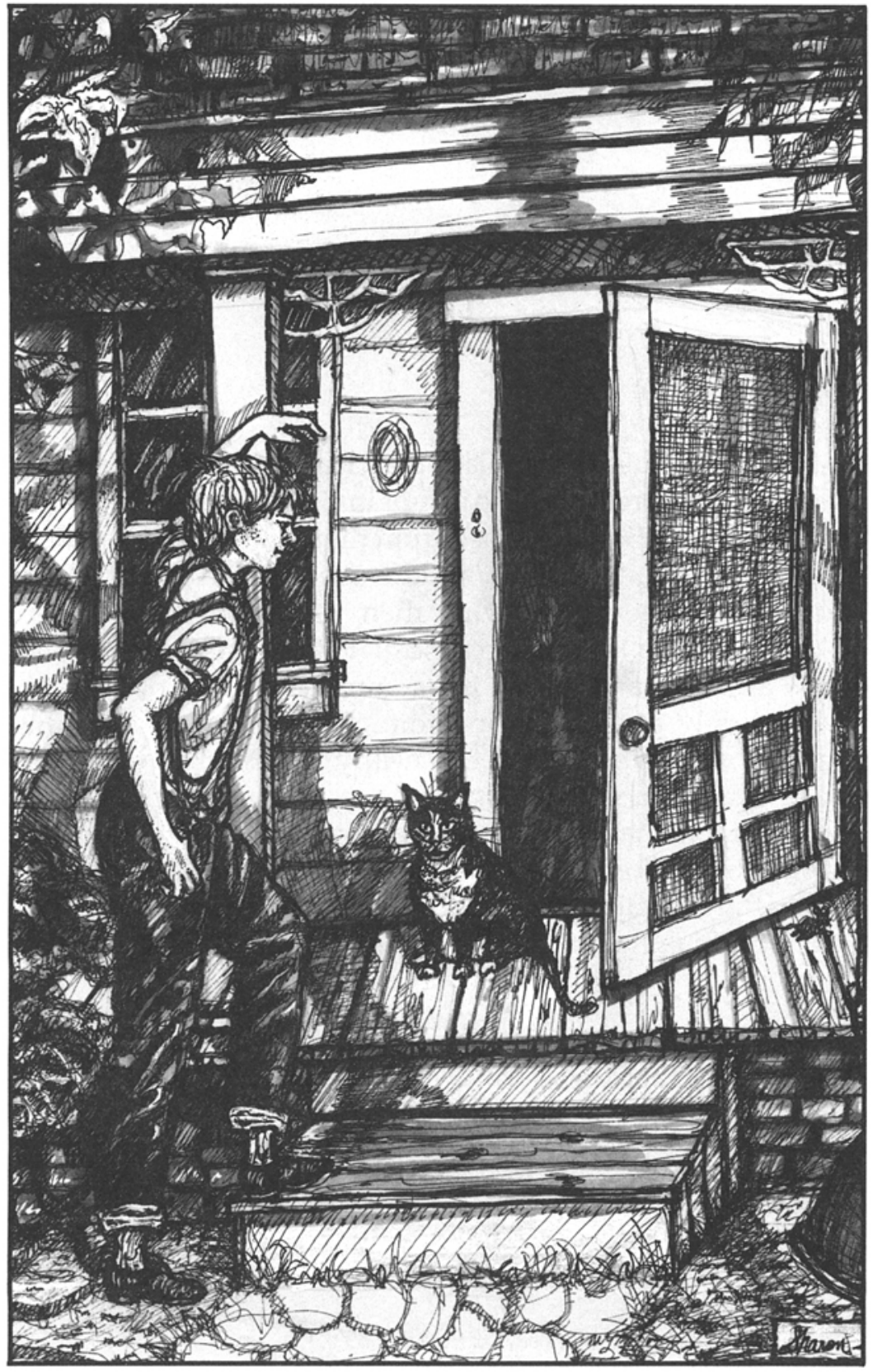


TSALI ( ? -1840)

Not all the Cherokee Indians marched the infamous Trail of Tears, the forced relocation to camps in Oklahoma that left 3,000 Cherokee dead. Some escaped from the soldiers and hid in the Great Smoky Mountains. A middle-aged Indian named Tsali, also called Charley by the white men, was one of them.

According to legend, because of Tsali's resistance, he was finally executed and buried in an unmarked grave along with all his family except for one son. The soldiers spared his youngest son, who joined the nearly 1,000 other Cherokee refugees in the mountains.

This legend has been preserved. Tsali's remaining son told his daughter, Norah Roper, who then told the story of her grandfather's refusal to abandon his homeland to Alice Marriott. Her book American Indian Mythology includes the story.

\section{Tsali of the Cherokees}

In the time when their troubles began ${ }^{1}$, the ordinary Cherokees did not at first understand that anything was really wrong. They knew that their tribal chiefs traveled back and forth to the white man's place called Washington more often

${ }^{1}$ In the time when their troubles began, in the 1830's. 
than they used to do. They knew that when the chiefs came back from that place there were quarrels in the tribal council.

Up in the hills and the back country, where Ani Keetoowahthe true Cherokees-lived, word of the changes came more slowly than the changes themselves came to the valley Cherokees. Many of the hill people never left their farm lands, and those who did went only to the nearest trading post and back. Few travelers ever came into the uplands, where the mists of the Smokies shut out the encroaching world.

So, when the news came that some of the chiefs of the Cherokees had touched the pen, and put their names or their marks on a paper, and agreed by doing so that this was no longer Cherokee country, the Ani Keetoowah could not believe what they heard. Surely, they said to each other, this news must be false. No Cherokee-not even a mixed-blood-would sign away his own and his people's lands. But that was what the chiefs had done.

Then the word came that the chiefs were even more divided among themselves, and that not all of them had touched the pen. Some were not willing to move away to the new lands across the Mississippi, and settle in the hills around Fort Gibson, Oklahoma.

"Perhaps we should hang on," the Ani Keetoowah said to one another. "Perhaps we will not have to go away after all." They waited and hoped, although they knew in their hearts that hope is the cruelest curse on mankind.

One of the leaders of the Ani Keetoowah was Tsali. The white men had trouble pronouncing his name, so they called him "Charley," or "Dutch." Tsali was a full-blood, and so were his wife and their family. They were of the oldest Keetoowah Cherokee blood, and would never have let themselves be shamed by having half-breed relatives.

Tsali and his four sons worked two hillsides and the valley between them, in the southern part of the hill country. Tsali and his wife and their youngest son lived in a log house at the head of the hollow. The others had their own homes, spread out along the hillsides. They grew corn and beans, a few 
English peas, squashes and pumpkins, tobacco and cotton, and even a little sugar cane and indigo. Tsali's wife kept chickens in a fenced run away from the house.

The women gathered wild hemp and spun it; they spun the cotton, and the wool from their sheep. Then they wove the thread into cloth, and sometimes in winter when their few cattle and the sheep had been cared for and the chickens fed and there was not much else to do, the men helped at the looms which they had built themselves. The women did all the cutting and the making of garments for the whole family.

Tsali and his family were not worldly rich, in the way that the chiefs and some of the Cherokees of the valley towns were rich. They had hardly seen white man's metal money in their lives. But Tsali's people never lacked for food, or good clothing, or safe shelter.

The missionaries seldom came into the uplands then. Tsali took his sons and their wives, and his own wife, to the great dance ground where the seven Keetoowah villages gathered each month at the time of the full moon. There they danced their prayers in time to the beating of the women's terrapin-shell ${ }^{2}$ leg rattles, around and around the mound of packed white ashes on top of which bloomed the eternal fire that was the life of all the Cherokees.

The occasional missionaries fussed over the children. They gave them white men's names, so that by Tsali's time everyone had an Indian name and an English one. The Cherokees listened to the missionaries politely, for the missionaries were great gossips, and the Cherokees heard their news and ignored the rest of their words.

"You will have to go soon," said one white preacher to Tsali. "There's no hope this time. The lands have all been sold and the Georgia troopers are moving in. You'll have to go west."

"We'll never leave," Tsali answered. "This is our land and we belong to it. Who could take it from us-who would want it? It's hard even for us to farm here, and we're used to hill

2 terrapin shell, turtle shell 
farming. The white men wouldn't want to come here-they'll want the lands in the valleys, if the lowland people will give them up.

They want these hills more than any other land," the missionary said. He sounded almost threatening. "Don't you see, you poor ignorant Indian? They are finding gold-gold, man, gold-downstream in the lower Keetoowah country. That means that the source of the gold is in the headwaters of the rivers that flow from here down into the valleys. I've seen gold dust in those streams myself."

"Gold?" asked Tsali. "You mean this yellow stuff?" And he took a buckskin pouch out of the pouch that hung from his sash, and opened it. At the sight of the yellow dust the pouch contained the missionary seemed to go a little crazy.

"That's it!" he cried. "Where did you get it? How did you find it? You'll be rich if you can get more."

"We find it in the rivers, as you said," Tsali replied. "We gather what we need to take to the trader. I have this now because I'm going down to the valley in a few days, to get my wife some ribbons to trim her new dress."

"Show me where you got it," the missionary begged. "We can all be rich. I'll protect you from the other white men, if you'll make me your partner."

"No, I think I'd better not," said Tsali thoughtfully. "My sons are my partners, as I was my father's. We do not need another partner, and as long as we have our old squirrel guns, we do not need to be protected. Thank you, but you can go on. We are better off as we are."

The missionary coaxed and threatened, but Tsali stood firm. In the end, the white man went away without any gold except a pinch that Tsali gave him, because the missionary seemed to value the yellow dust even more than the trader did.

Then it was time to go to the trading post. When Tsali came in the store, the trader said to him, "Well, Chief, glad to see you. I hear you're a rich man these days."

"I've always been a rich man," Tsali answered. "I have my family and we all have our good health. We have land to farm, 
houses to live in, food on our tables, and enough clothes. Most of all, we have the love in our hearts for each other and our friends. Indeed, you are right. We are very rich."

"That's one way of looking at it," said the trader, "but it isn't what I was thinking about. From what I hear, there's gold on your land, you've got a gold mine." man."

"A gold man?" repeated Tsali. "I never heard of a gold

"No!" shouted the trader. "A gold mine, I said. A place where you can go and pick up gold."

"Oh, that!" Tsali exclaimed. "Yes, we have some places like that on our land. Here's some of the yellow dust we find there."

And he opened the pouch to show the trader. The trader had seen pinches of Tsali's gold dust before, and taken it in trade without saying much about it. Now he went as crazy as the missionary. "Don't tell anybody else about this, Charley," he whispered, leaning over the counter."We'll just keep it to ourselves. I'll help you work it out, and I'll keep the white men away. We'll all be rich."

"Thank you," said Tsali, "but I don't believe I want to be rich that way. I just want enough of this stuff to trade you for ribbons and sugar."

"Oh, all right," answered the trader sulkily, "have it your way. But don't blame me if you are sorry afterwards."

"I won't blame anybody," said Tsali, and bought his ribbon.

A month later, when the Georgia militia came riding up in the valley to Tsali's house, the missionary and the trader were with them. The men all stopped in front of the house, and Tsali's wife came out into the dogtrot, the open-ended passage that divided the two halves of the house and made a cool breezeway where the family sat in warm weather. She spoke to the men.

"Won't you come in and sit down?"

"Where's the old man?" the militia captain asked.

"Why, he's working out in the fields," said Amanda. "Sit down and have a cool drink of water while I send the boy for him." 
"Send the boy quickly," the captain ordered. "We'll wait in our saddles and not trouble to get down."

"All right, if you'd rather not," Amanda said. "Do you mind telling me why you're here?"

"We're here to put you off this place," said the captain. "Haven't you heard? This isn't Cherokee land any more; the chiefs signed it over to the government and now it's open for settlement. One or the other of these two gentlemen will probably claim it."

"They can't do that!" Amanda protested. "It's our landnobody else's. The chiefs had no right to sign it away. My husband's father worked this place, and his father before him. This is our home. This is where we belong."

"No more," said the captain. "You belong in the removal camps down by the river, with the rest of the Indians. They're going to start shipping the Cherokees west tomorrow morning."

Amanda sat down on the bench in the dogtrot, with her legs trembling under her. "All of us?" she asked.

"Every one of you." said.

"Let me call my son and send him for his daddy," Amanda

"Hurry up!"

Amanda went into the house, calling to the boy, who was just fourteen and had been standing, listening, behind the door. She gave him his father's old squirrel gun, and he sneaked his own blowgun and darts and slid out the back of the house. Amanda went back to the dogtrot and sat and waited. She sat there and waited, while the missionary, the trader, and the captain quarreled about which of their wives should cook in her kitchen. She let them quarrel and hoped her men were all right.

Tsali and his older sons were working the overhill corn field, when the boy came panting up, and told them what had happened.

"Is your mother all right?" Tsali asked.

"She was when I left," the boy answered.

"We'll hide in the woods till they're gone," Tsali told his 
older sons. "If they find us, they'll have to kill us to put us off this land."

"What about the women?" the oldest son asked.

"They'll be all right," Tsali answered. "Your mother's a quick-thinking woman; she'll take care of them. If we can hide in the caves by the river till dark, we'll go back then and get them."

They slipped away into the woods, downhill to the river, taking the boy with them, although he offered to go back and tell the white men he couldn't find his father.

All afternoon Amanda waited. Her daughters-in-law saw the strange men and horses in front of the big house and came to join her. At dusk, the captain gave up and ordered his men to make camp in the front yard. "We'll wait here until the men came back," he said.

With the white men camped all around the house, the women went into the kitchen and barred all the doors. It was a long time before the campfires made from the fence pickets ceased to blaze and began to smolder. It was a longer time until the women heard it-a scratch on the back door, so soft and so light that it would have embarrassed a mouse. Amanda slid back the bar, and Tsali and his sons slipped into the darkened room. There was just enough moonlight for them to make out each other's shapes.

"We came to get you," Tsali said. "Come quickly. Leave everything except your knives. Don't wait a minute."

Amanda and her daughters-in-law always wore their knives at their belts, so they were ready. One at a time, Tsali last, the whole family crept out of their home and escaped into the woods.

In the morning, when the white men stretched and scratched and woke, the Ani Keetoowah were gone.

It was spring, and the weather was warm, but the rain fell and soaked the Cherokees. They had brought no food, and they dared not fire a gun. One of the daughters-in-law was pregnant, and her time was close. Amanda was stiff and crippled with rheumatism. They gathered wild greens, for it was too 
early for berries or plums, and the men and boy trapped small animals and birds in string snares the women made by pulling out their hair and twisting it.

Day by day, for four weeks, the starving family listened to white men beating through the woods. The Cherokees were tired and cold and hungry, but they were silent. They even began to hope that in time the white men would go away and the Indians would be safe.

It was not to be. One trooper brought his dog, and the dog caught the human scent. So the dog, with his man behind him, came sniffing into the cave and Tsali and his family were caught before the men could pick up their loaded guns.

The militiaman shouted, and other white men came thudding through the woods. They tied the Cherokee men's hands behind them and bound them all together along a rope. The militiamen pushed Tsali and his sons through the woods. The women followed, weeping.

At last they were back at their own house, but they would not have recognized it. The troopers had plundered the garden, and trampled the plants they didn't eat. The door from the kitchen into the dogtrot hung askew, and the door to the main room had been wrenched off its hinges. Clothes and bedding lay in filthy piles around the yard. What the militiamen could not use, they ruined.

"Oh, my garden!" cried Amanda, and when she saw the scattered feathers, "Oh, my little hens!"

"What are you going to do with us?" Tsali demanded.

"Take you down to the river. The last boat is loading today. There's still time to get you on it and out of here."

"I-will-not-go," Tsali said quietly. "You-nor younor you- nobody can make me go."

"Our orders are to take all the Cherokees. If any resist, shoot them."

"Shoot me, then!" cried Tsali. The captain raised his rifle.

"Stop!" Amanda screamed. She stepped over beside her husband. "If you shoot, shoot us both," she ordered. "Our lives have been one life since we were no older than our boy here. I 
don't want to go on living without my husband. And I cannot leave our home any more than he can. Shoot us both."

The four sons stepped forward. "We will die with our parents," the oldest one said. "Take our wives to the boat, if that is the only place they can be safe, but we stay here." He turned to his wife and the other young women.

"That is my order as your husband," Tsali's son said. "You must go away to the west, and make new lives for yourselves while you are still young enough to do so." The wives sobbed, and held out their arms, but the husbands turned their backs on the women. "We will stay with our parents," all the young men said.

The young boy, too, stood with his brothers, beside his father. "Let this boy go," Tsali said to the white men. "He is so young. A man grows, and plants his seed, and his seed goes on. This is my seed. I planted it. My older sons and I have had our chances. They will leave children, and their names will never be forgotten. But this boy is too young. His seed has not ripened for planting yet. Let him go to care for his sisters on the way to the west."

"Very well," said the captain. "He can't do much harm if he does live." He turned to the two militiamen. "Take the boy and the young women away," he ordered. "Keep them going till they come to the boats, and load them on board."

The young women and the boy, stunned and silenced, were driven down the road before they could say good-by, nor would the troopers let them look back. Behind them, as they started on the long main road, they heard the sound of the shots. 


\section{Tsali}

1. In what ways do the values of Tsali differ from those of the men who want his land?

2. Does Tsali fit your concept of a hero? Explain.

3. The conflict between the white man and the Indian is an age-old one. What are some of the basic causes of this conflict as illustrated in the story of Tsali?

4. The word seed is used symbolically at the end of this story. Discuss its meaning.

5. Is there evil in this story? Is there good? Are they presented implicitly or explicitly? 


\section{CRATIS WILLIAMS (1911-1985)}

Cratis Williams was a noted folklorist. He grew up in Big Sandy Valley in Kentucky.

Williams attended Cumberland College in Williamsburg, Kentucky. He received his bachelor's and master's degrees from the University of Kentucky and his doctorate from New York University. He taught at Appalachian State University where he became dean of the graduate school and where in 1974 he served as Acting Chancellor.

His writings include scholarly works on the Southern mountaineer and Appalachian speech.

The following was taken from a presentation he was invited to make describing the many characteristics of the dialect of the Southern Appalachian region.

\section{Dialect and Speech}

Begin, began, begun, for the mountaineer is begin, begin, begin or once in a while begin, begun, begun. This is a fairly easy thing to remember: the mountaineer has a prejudice against any past tense in which the middle vowel in standard English has become an $a$. Also, he does not bother his head in any way with fine distinctions in the use of such verbs as sit, set; lie, lay; rise, raise. Do you recall how your English teachers beat your heads 
just trying to help you get those things straight and made you so self-conscious that you had to put on the brakes while you figured out whether to say "sit" or "set"? The mountaineer doesn't have that trouble; he is very economical. He says "set" every time. He never says "sit," a putting-on-the-dog kind of word. He wouldn't say "sat" at all. It's "set" every time. To him, "lie" means to bear false witness, and except for that, he uses "lay" every time. The sun will "rise," and one can have a "risin," a bealing or a boil, on him. In other instances, one uses a form of "raise," as "He raised up." Perhaps that's enough about verbs, except that once in a while one will be astonished to hear a strange verb form that he has never heard before, like "skunt" for "skinned" or "juked" for "ducked."

Here is a line from a song: "He beat his breast and away he swom." An old woman might say she "shot" the door, but more often one would hear "shet." The mountain person also says "tuck" for "took" and "shuck" for "shook," as "He tuck it outside and shuck it." However, in mountain speech most double "o's" are pure.

You can find vittles in a dictionary. It's a perfectly good word, and the mountaineer pronounces it correctly. It means food and is spelled victuals and pronounced vittles, the only pronunciation allowed for it. There's nothing wrong with the mountaineer's use of fetch, also a perfectly good word.

And poke, of course, Chaucer used. Everybody knows the expression "pig in a poke," though most people that use it don't really know what it means. Poke is a Middle English word which means bag.

If one has a polysyllabic word for a name, then, in the hill country he might have it reduced to one syllable or two. "Ebenezer" might become "Eb" or "Ebby"; "Cassandra" might be shortened to "Cassie"; or "Martelia" might become "Teal."

In the word sergeant we still preserve the old fashioned pronunciation of that $e$ before the $r$. We still say "sargent." The old fashioned mountaineer, when he got around to using the word eternal, said etarnal. In time he dropped the first syllable and said 'tarnal. Tarnation has to do with damnation, and is a 
mild curse word. It would be used only in a polite situation, for when the mountaineer is in the right situation and wants to curse he has a magnificent vocabulary. He knows how to put things together. Scurillity, obscenity, and oaths he can weave together in an almost poetic discharge. But he has to be in just the right mood and in a real rage to do that. In polite society he'd use such words as tarnation or tarnacious.

Double negatives are used for emphasis, as Shakespeare $\mathrm{did}$, and the Bible does. Therefore, the more you want to make a thing positive the more negatives you use. That's the way the mountaineers do it. That's the way it should have remained. The English teachers became bothered by negatives and started applying mathematics. They began talking about one negative's cancelling out another. "She don't never mean to do nothing, nohow, no time, no way about it." Now can one be more positive? I believe there are six negatives in a row in that sentence.

I've already referred to the mountaineer's fondness for the Middle English preposition a-. He's fond of prepositions generally and the more of them he can put into a sentence the more accurately he believes he is saying what he means. Prepositional clusters in mountain speech are magnificent. They are handled so skillfully that they sometimes sound like one word. Unless you are really listening you don't notice them. You have heard fur to (for to). "Fur to make a rabbit pie, you've got first fur to catch a rabbit."

Once, when I was a little boy, my mother was making pies one Saturday morning. I wanted one of those pies but she told me, "No, these pies are for company." I waited until she was busy in the kitchen, which joined the dining room. She had set the pies on the window ledge in the dining room to cool before putting them in the safe, a kind of cupboard, kept in the corner, which had metal doors and sides with perforations in the metal for ventilation. But the holes were so small that insects couldn't get in. We had no refrigeration then. We had a big dining room table with an ornately flowered oil cloth cover that came almost to the floor all the way around. When I found my mother preoc- 
cupied in the kitchen, I stole one of those pies and crept far back under the table to eat it. I was doing quite well with it when I heard my mother walk across the floor. All I could see were her shoes. She walked over to the window ledge. There was this very dramatic silence. I was holding my breath. My mother was not making a sound. In a moment, she lifted the corner of that tablecloth slowly, and peeked under it. With her face upside down, she said, "You come on up out from back down in under there, or I'll wear every bit of hide from off'n your back." Let me repeat exactly what she said. "You come on up out from back down in under there. I'll wear every bit of hide from off from up on your back." One couldn't be more precise than that. But a long time ago we were told that we don't need all of those prepositions. You have to listen for them. They almost come out as one word.

I want now to tell the beginning of a folktale, "The Fox and the Bumblebee."

One'st they's a fox'at 'lowed one mornin' he'd walk down to the mouth of the creek to the store. He had to have him a quarterlampal, an' a plug o' chawin backer, and he 'lowed by gonnies he might buy 'im a can of sammons if the price uz right. And whilst he uz a-sankerin along, a-thankin about first one thang and then t'other, he seed one of these here big yaller stripedy bellied bummel bees a-smoulin over a flare blossom 'at uz a-growin on a mornin glory vine on one of the postes thar by the side of the big road. So's'n he snuck up right easy like and rech out and snabbed him and popped him into a poke he had with'm, and then went on. Ditn't git stung nary time. D'reckly, he come to this here house 'at as a-standin acrosst the branch. He walked right down ferninst the door and hollerd "hello." A womern come and stuck her head out and said, "What'd you have, mister?" The fox says, "How about me a-leavin this here poke here whilst I go on down to the mouth of the creek to the store? I've got to git me a quart of lampal and a plug of chawin backer and I 'lowed by gonnies might buy me a can of sammons if the price is right." The womern said, "Why, come right in, if you can git in. I been aaimin to reddin up this here old place fer mighten nigh a 
week, but a body can't never git around to a-doin nothin, don't 'pear like. Jist putt it down yan side of the farplace, if you can find room fer it."

Well, the fox he walked over and putt the poke down. Then, he looked at the womern right straight like, and says to her, says, "Now, don't you be a-openin that there poke whilst I'm gone." And then he went on.

Well, agin he's out $o^{\prime}$ sight and sound of the house, the womern says, "Now, I jist wonder what's in that there poke? Aye gonnies, I'll see." So's'n she walked over and picked up the poke, ontied the strang, onwropped it, flipped the poke open, and the bee, $o$ ' course flew out, but her old rooster 'at jist happent to be a-standin there tuck out atter it. But, the dang thang got away. She tied the strang back, jist like it was, best she could ricollect, putt the poke back down, hooved it up a little in the middle so's'n hit'd look like hit hatn't been teched, and went on about her work. Atter a while the fox comes back. He walks over and picks up the poke, onties the strang, onwrops it, but the bummel bee $o^{\prime}$ course is gone. He says, "Whur's my bummel bee?"

The womern says, "Why, I jist ontied the strang and opened the poke, and the bummel bee flew out. My old rooster jist happent to be a-standin there tuck out atter it, but the dang thang got away. "Then," says the fox, "the rooster is mine." So's'n he ketched the rooster and popped him into the poke and then he went on.

You know the story, I suppose. It is one of those aroundand-around stories. The fox goes from one house to another, repeating the same kind of deal.

It's incorrect in America to add a $t$ as in onest, but old fashioned Americans do. Onest and twicet are not restricted to the mountains. One hears them in the Midwest also. Aye in "aye gonnies" means yes. Gonnies, a mild oath, might have something to do with what belongs to God, but is perhaps a dialectical pronunciation of "guineas," which were British gold pieces. I used to hear my father say that. The mountaineer will 
also say "by Jacks," which might mean "by Jackson" for Andrew Jackson, a great hero of the mountain folk, who still swear by him. According to records, many mountaineers continued to vote for Andrew Jackson for President for a generation after he died because they refused to vote for anybody else.

"By gollies" may perhaps mean "by God," but I don't know. The go suggests God. Gollies might mean "God's laws." I've forgotten what gollies means, if I have ever known. "Gosh" means "God's wash," God's bath water, I believe.

Outsiders say we'uns. I have never heard the mountaineers use the terms we'uns, you'uns, and his'un, and I've listened carefully. The outsider coming to the mountains will hear you'uns and our' $n$, and he'll go back home absolutely convinced that he heard them say we'uns, too, but I don't believe I have ever heard one say it. I always insist that they don't say it, but sometimes people will say to me, "Oh, you just haven't been listening. I know some who say it." I ask them to listen for it again and the next time they hear it to write it down and send me a note about it. I've received no notes. I believe people just think they have heard it.

The syllabicated plural, as in ghostes and postes, was common in Middle English. One finds it in Chaucer's works. Third person present tense verbs are also syllabicated sometimes, as in "He boastes too much," or "She roastes chicken over a open far."

The speech I was using in the story, incidentally, is the finest speech that a semi-literate or illiterate grandmother might use in telling her little grandson a story. That speech as delivered is spoken by perhaps not more than one million of the eight or nine million Appalachians still living in Appalachia. But everybody of Appalachian origin will have, unless they have worked very hard to improve their speech, some of the characteristics of the speech in the story I have told you. And that's to put the speech in the story in perspective so you won't think all mountain folks speak that way.

Younguns, right out of Anglosaxon, means children. It's an Anglosaxon word that means "young ones." But it's not quite 
the same as "we'uns" and "you'uns." Let's assume that "we'uns" is sometimes heard. I've never heard it used but let's assume it is. What does it mean? It means "we ones." Is there anything grammatically wrong with that? No. It's just for emphasis. "You'uns," exactly the same, means "you ones." "Your'n" means "your own." It's an idiomatic use. "Their'n," meaning "their own," is another.

"You all" is not typical mountain speech. It's an interloper, an intruder, from outside. It's the kind of thing that self-conscious Southerners will drawl in order to call attention to themselves as Southerners, for Southerners are proud of their speech. Mountaineers are ashamed of theirs.

"Sallet" is used for salad throughout the mountains but I believe it is heard elsewhere in the country, too. You probably hear it more often here. In the mountains it doesn't mean the same as salad. One might hear a mountain person talk about the salad and the sallet. He has two different things in mind. Sallet is greens he gathers in the garden and cooks.

I remember my greatgrandfather, who died when I was 21. He used very old fashioned English, and as far as I know he was completely illiterate, but he would say "s' $I$ " and "s'e" and "sas' $I$," and "sas'e," meaning "says I" and "says he." He died at the age of 93. His speech went away back almost to the time of Daniel Boone, who would have used these expressions, too.

Mountain folk use weak forms of some verbs that remain strong verbs in standard English. Seed is one of them. They will say see, seed, seed, or seen. They have retained the Anglosaxon concept of the verb learn. In Anglosaxon, learn meant "to learn" or "to teach" either. So to the man who lives in the hills, "to teach" means simply to hold a school. He says teached instead of taught, but learn has to do with the act of learning. A mountaineer might say of a teacher, "We don't want him back in this community no more. He teached the poorest school I can remember. He didn't learn the younguns a thing."

The mountain people have simply retained the old speech because they have been isolated. They have retained what appears to have been general among the Scotch-Irish at the time 
of the American Revolution.

Some of these Scotch-Irish moved to other places and they carried their speech with them. One could go into the Ozarks, for example, and hear the same kind of speech we have here. One could go into Southern Indiana, where communities have retained their Scotch-Irish descendants, and hear the same kind of speech, or Ohio, or Illinois, or Missouri, even upstate New York. Wherever they went they carried their speech with them.

"Again" is used as an adverbial conjunctive. That's the way it was in Middle English times. We had a man at Appalachian State University who worked for us a long time, a fine professor who used that all the time and never was aware that it was a mountain usage. One could hardly tell that he had a mountain origin, really. But he retained this and was not aware of it. It's interesting, too, that the mountain person seems to think again is two words, that gain is a noun and the object of the preposition $a$. He thinks this is a noun, I suspect, although he doesn't use the word as a noun. He'll say, "Well, he done it, and I said something to him, and then he done it again. I didn't want no trouble with him, but then he done it another gain, and I let him have it right between the eyes." He will say, "He done it again, and again, and then another gain." While I was in Kentucky last weekend I heard that. The mountaineer senses again as an adverbial conjunction, but it has long since ceased to be used as that in standard English.

Did you notice in the story of the bumblebee that the teller of the story wanted to explain the obvious to you? "The bummel bee, of course, was gone." This reflects the literal mind of the mountaineer. With all of his good qualities, he is also literal minded. The Bible means just exactly what it says, not one word more. The mountain preacher must preach exactly from that Bible. If he has an argument to make, he marshals his arguments by quoting chapter and verse. Anything he says away from the Bible is thought of as "not Godly." He retains literal notions of politics, too. Politically, he tends to be just what his pappy was and he doesn't want to change. General- 


\section{Oral Tradition}

ly, he has not learned how to be abstract. Since he works from facts only, he seems unable to engage in abstractions. He doesn't understand courts of law that deal with civil issues. In fact, he doesn't trust the courts at all. He thinks the courts are instruments that provide for the manipulation of his affairs by his enemies. Typically, he would rather solve his own problems.

\section{Dialect and Speech}

1. How is the mountaineer economical with verbs?

2. Suggest examples of polysyllabic names that are shortened in the way Ebenezer and Cassandra are.

3. What was the original purpose of double negatives? 


\section{JEAN RITCHIE (1922- )}

Jean Ritchie was born the fourteenth child in a family of singers and storytellers in Viper, Kentucky.

After graduating from the University of Kentucky with a degree in social work, she went to New York to work in the Henry Street Settlement School. There she sang her way into the hearts of the settlement residents and met folklorists Alan Lomax and Burl Ives, who gave her opportunities to perform and record. These opportunities lead to her worldwide fame as a dulcimer player.

In 1952 she received a Fulbright Scholarship to study folklore in the British Isles. She was one of the seven to make up the original board of directors of the Newport Folk Festival. Since the publication of her book Singing Family of the Cumberlands in 1955, she has continued to write, perform, and record.

In this excerpt from that book, she writes about her parents' meeting and marriage and the influence of singing and storytelling in the Ritchie family.

\section{From Singing Family of the Cumberlands}

Oftentimes we would pester Dad to tell us about how he had met up with Mom, and how they had courted and so on. Children are so curious about such things. But he would never 
want to talk about that to us, and always told us to hush-it wasn't none of our business. He wouldn't get mad when we asked him, but just acted like it shamed him, and he would look sideways at Mom and give a little dry laugh and go out and study the weather.

It was the evening of their golden wedding anniversary that we finally got all the facts out of Mom and Dad. A soft June evening. The whole community had been in and out of our place that day, paying honor to them. We had cooked for weeks to be able to accommodate everybody with chicken and dumplings with all the trimmings, and it sure had been a big day. All the people brought presents, too. Dad had several gold tie-clasps and watch-chains, Mom had golden haircombs, earrings, and all kinds of jewelry, and there were stacks of gold-trimmed trays, dishes, flower vases, and knickknacks, all over the place. Best of all her presents Mom loved the one she got from Dad-a gold wedding band. After all these years!

'I reckon that settles it. I'm really married,' she said.

Finally toward evening everybody went home, and we were resting ourselves with hot tea around the table. Dad had gone off to take a nap after the hard day. The ring must have given Mom nerve, for after a while she went off into their room and came back with a letter.

'I want all you children to see your Pa's letter,' she smiled. 'It's his first one he ever wrote to me. Handle it careful, it's old and crackly. Hard to read, too, yellow and fady, but you can tell what a pretty hand to write he was then. See how even the strokes of it, and the lovely curlicues! He was allus the best scribe in the countryside about, anybody will tell you that.'

Miss Abigail Hall

Dwarf, Kentucky, June the 23, 93

Viper, Ky.

Unknown Friend,

A friend of yours, Miss Sallie Hall, says that you said you wanted some pretty boy to write to you. I guess you was just 
joking if you said that to Sallie, but nevertheless I take the liberty of addressing you, asking you to pardon me for my boldness.

You need not think I am good looking by me writing, for I am not.

Some of the boys has told me you are a nice pretty girl and of course I would love to see you, for I think we could be friends, don't you?

I will give you a brief description of myself so you may judge what I look like.

I am a young man 23 years of age, height $5 \mathrm{ft} .10 \mathrm{in}$. weight $150 \#$, fair complexion, black eyes, light hair and stooped shouldered.

If you axcept me as a correspondent I Think we could have some real good fun writing to each other, and very likely our correspondence would lead to something more serious.

There is nothing that gives me more pleasure than receiving nice letters from the girls except being honored with the company of the writer.

I have several correspondents who are strangers to me but we are interested in each others letters and if you answer this favorable I think I can interest you next time. If you should care to see my picture I will send you one with pleasure if you will send me yours. (After I send mine).

Waiting anxiously for a favorable reply,

I remain Your Unknown Friend,
Balis Ritchie
Dwarf, Ky.

Dad came stomping to complain that he couldn't sleep for the noise we were making, and, of course, he saw what it was we were all exclaiming over.

'Abbie, what you a-doing?' He looked sheepish. But we wouldn't hush, and we asked them all manner of questions. Pretty soon they got to having such a good time recollecting that they well forgot we were there in the room.

Mom began musing out loud. 'This'ns the very first love 
letter I ever got, and then next week he come to see me. Lordie, Balis, do you remember when's the first time you laid eyes on me? It's a pure wonder you would have me after that, but I didn't take to you much neither that first sight we had of one another!

'Pap and all of us were in the field above the house one day in July. It was nigh dinnertime, and we'uz a working hard to get our round hoed out when here come Betton, my baby sister, just a-cutting through the stalks. She couldn't get good breath, she had run so fast. Pap grabbed at her, scared to death. He thought Mam was sick or something.

"There's a stranger home," she was just grinning and jumping up and down and acting so feisty. "He's the properest thing. Says he's a schoolteacher. From over in Knott he comes."

"Well what's he wanting here?" Pap wondered. Pap was a good man. He looked off toward the house and fanned himself with his old flop hat. At last he struck his hoe into the ground and started off down the hill. "Dinnertime anyway. Guess maybe I ought to be seeing what he needs of us."

'Betton hollered, "Hunh, he ain't a-wanting to see you. He's come to spark Abbie. He says, 'Does Miss Abigail Hall live here?" She was a-mocking his voice. "And when I said yes, he lit right down off'n his hoss and come in, said howdy to Mammy Sally, said he guessed he'd wait till Abigail got in home." Betton, she tore out through the corn, and I threw the hoe after her.

"Hush you scamp. You don't have to holler so loud and act so crazy. Wait'll I catch up with you, little feisty-britches!"

'Boys, I hated to go in home worse'n I ever hated to do anything. I was the messiest, dirtiest, poorest-looking critter you ever did see. Barefooted, old brown calico dress all tore and faded, old, black, dirty man's hat with holes in it big enough to throw a cat through. Sweat a-streaming down to my toes, and cornfield dust all over me. And the other girls and Philip 'uz all a-teasing the life out of me cler down the hill, having them a big time. Then to cap it all Mammy Sally run out into the side 
yard and commenced blowing the living daylights out of the old dinner-horn. Musta blowed it ten or fifteen times fore she run out of breath. Any other time we'd a-thought the house was afire or something, but today I knew it was just her way of teasing me, too.

'Well, I got down to the back gate, and I couldn't stand the thoughts of saying howdy to him and me looking thataway, so I slipped around the backside of the house. Thinks I, I'll just slip in the back room and change my clothes, put on some shoes, and make Betton bring me the washpan back there. Sailed around the corner of the house, and there he was adrying his hands on the towel, and a-grinning like he knew I'd come thataway. Mammy Sally had set him up in the back room to wash and get ready for dinner. Boys, I wisht then I could sink plum through the earth. I wheeled and tuck back around the house. I was so hot and sunburnt and mad that I couldn't see straight. I thought I never would get over it, him a-catching me like that, and him so proper. Istomped into the kitchen, and I just felt like laying them all out east and west.

'Mam whispered, "Well, lassie, wait till you see what a proper man has come to see you!"

'I was about to bust out crying then, and I hollered, "I've done and seen him! Mary-Ann or Rhodie can have him for all I care too. I think he's the ugliest thing I ever saw in my life and I'm not going to pay any attention to him."

'So I just washed my face and hands and that's all. Come to the table barefooted and in my ragged dress. Couldn't think of a solitary thing to say to that feller. He kept looking at me and grinning, and I kept on looking at the vittles on my plate. Mammy Sally and Pap and t'others seemed like they had a good time talking to him and listening to him tell, but I couldn't open my mouth to save me. It's a pure wonder he ever looked at me again.

'He came back to see me though. Kept right on till we got so we could talk to one another, and somewhere in during that year we got to talking about marrying. So, we'uz promised. I was sixteen and him twenty-three. That winter he had to study 
for his teaching certificate, and couldn't come over much, and then, too, it was a long trip through the mountains from Knott County in the winter weather. In wintertime at home we generally had school for a few months, and I went steady that year. He seemed so much smarter than me!

'I was in what you'd call about the sixth or seventh grade nowadays, somewhere along there. But it was a hard matter to keep my mind on book learning, so it didn't make much difference to me what grade I was in. I'd set with my eyes on the snowy hills and dream about my wedding day. What it would be like, how long off and how close up it seemed, and what kind of cloth Pap would bring me for my dress. To this day I can't work sums and fractions because my mind just wasn't on the lessons that year. 'Pears like I wanted to study and learn, but I couldn't somehow, to do any good.

'About the only thing I did learn that whole winter was, I remember, one day some of us girls were a-walking together at recess and Mary Jane Combs got to singing at a little song. Foolish little thing, but I got struck on the words and that evening I walked home with her and made her sing it over until I learnt it. After that I sung it around the house so much that Mammy Sally threatened to whup me if I didn't hush. It was "Somebody.""

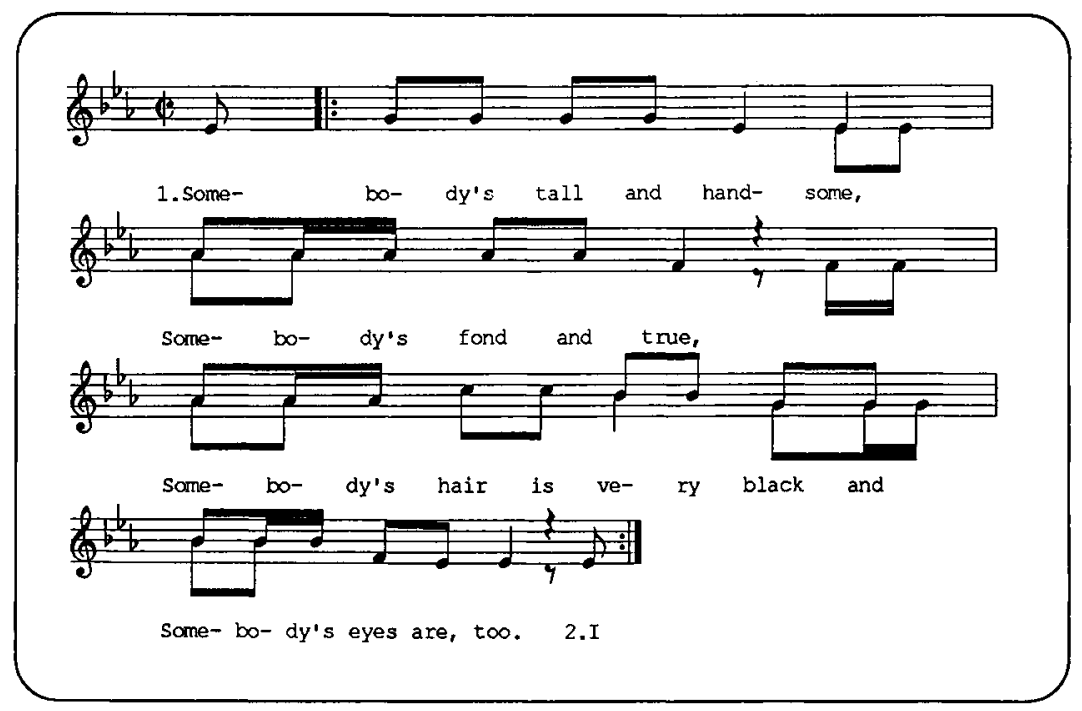


Somebody's tall and handsome,

Somebody's fond and true,

Somebody's hair is very black and

Somebody's eyes are, too.

I love somebody fondly,

I love somebody true,

I love somebody with all of my heart

And somebody loves me too.

Somebody came to see me,

Somebody came last night;

Somebody ask me to be his bride

Of course I said all right.

I am somebody's darling,

I am somebody's pride,

And the day is not far distance

When I'll be somebody's bride.

Somebody's tall and handsome,

Somebody's fond and true,

Somebody's hair is very dark,

Somebody's eyes are, too.

'That's pretty. I remember it well, mighty well,' said Dad. 'Seems like I heard it, "Somebody's eyes are blue," though.' Dad has brown eyes.

Mom looked flustered at that, and dropped her eyes to her lap. You could hardly hear what she said when she spoke. She was all smiling. 'It is supposed to be thataway. But I changed it a little,' she said. We all stayed quiet and by and by she remembered some more.

'On the day we got married I rose up before day and crossed over the river down yonder at the shoal to where the rhododendron was blooming there at the foot of the mountain. Seems like it always did grow the tallest and bloom the biggest whitest blossoms right there. I had got a notion to carry flowers 
at my wedding, and I had been spying on the rhododendron for several days. I gathered my arms full of them and waded back over and started to getting ready. I had to iron my dress, taking care not to scorch it, it was so white. Dad got the goods at the store. It was thin white goods with little ribs in it-now I forget what we called it-and I made the dress myself, in the pattern they made dresses then, with long puff sleeves and a high neck and full gathered skirt.

'The morning passed away so quick, and before I knew it Balis was there, and we were standing up together in the yard, getting married. Uncle Ira Combs married us-I asked for him special. Dad had on a new suit, and I thought I was sure getting a pretty man. They combed my hair and fastened it with combs, and carrying the flowers made me feel pretty and fine.

'The old custom is to stay the first night at her father's house, have a party and the wedding breakfast and so on, then to go the next day to his father's house, for the infare. I remember we got up early that first morning of our married life, and we saddled the horses before the rooster crowed and were on the way to Clear Creek before the sun rose. That's thirty mile easy. See if you catch folks today setting out to ride thirty mile one day's trip on a nag! Only way we had though, and it was a high good day we had for going. The sun was shining and it was right warm and windy. My traveling dress was black sateen with white collar and cuffs, and I wore that and rode side-saddle. That was a funny time that trip. Doe Ritchie they call him now, Sam his name is, he took a notion to go along with us to the infare, and he's allus a right jokey kind of feller. Going across the Duane Mountain he got to showing off what a good rider he was, turned himself around right backards on the old mare and went whooping and hollering, making that nag just gallop along. Come to a bunch of cattle lying in the road, and he says, "Watch me ride right through them cows and not touch a one!" He rode in amongst them, but he couldn't see so well, him setting backards, and as he was twisting around trying to keep the mare from stepping on a cow, a little black yearling raised up right quick just as the horse went 
over it. Hit the horse in the belly and she reared and Sam went flying off on his head. Didn't have a thing to catch onto, the way he was sitting. Swear we liked to have died laughing at him, soon as we found out he wasn't hurt much.

'Well, we pulled in about dinnertime, and they's all waiting for us. I reckon all of Clear Creek was there to see us ride in, and to take our infare with us. The dinner was sitting on the table ready. Chicken and dumplings and turkey and dressing, fresh-killed pork, squirrel, cakes and pies and garden truck. We all sat down to eat and we didn't get up from that table until near dark, and then as I recollect it we wound up with dancing and gaming and singing all night till clear daybreak. Wasn't that a time!'

Dad broke out laughing with his own memories. 'We'd not been married but a day or two when they took a notion to shivaree us. Lordie mercy, seemed like they'uz a hundred people come in on us, but we got to naming them after that and it was just ten or fifteen boys and girls around on the Creek. But they were a-meaning business and I guess they'd shore have rid me on a rail, hadn't been for Mam getting so vexed and getting ahead of them.

'We were staying at my Mam's then, Granny Katty's, until we could move out to ourselves. Abbie and Katty had just finished washing the supper dishes. We had been somewheres that day, and had a right late supper. Katty was complaining because it was so dark and she had to burn up so much coaloil to light our supper and their kitchen work afterwards. As I recall, it was one of the black dark nights when you couldn't see hand fore your face, no moon, and clouds kivering the stars up solid. I sot on the porch awhile until I heard them come out of the kitchen and I got up to go in where they were at, and when my eyes hit that light I commenced batting my eyelids, couldn't see a mortal thing. Little old oil lamp didn't give off much light, you know, but that thick night had really settled in my eyes and even that much light fixed me up so I couldn't see for a minute.

'Whilst I was blinking in the doorway there, the women- 
folks got awful still and Abbie said, "Katty, do you hear something?"

"Why yes, I do hear like people whispering and giggling. I thought it was Balis a-humming to himself but yander he stands on the doorsill."

'Bout that time a man's voice hollered out, loud as a thunderclap, "All right, Balis, come on out now you and Abbie! We come to get you!"

'Didn't take Mam no time to get it sized up. "Them scalawags. They' re a-coming in now for to shivaree you young uns. Confound their hides! You'd think they'd be dacent enough to wait a week, anyways. Run, Abbie, you and Balis, you-all can slip out the front way and run off down in the bottom there and hide. I'll tell them rascals you'uns went to Hindman this morning early. Hurry!"

'She pushed the both of us out into the night and shot the door soft, and me and Abbie here lit out down through the bottom, a-stumbling and a-falling along in gyarden truck. By that time my eyes had give it up; I might just as well been stone blind. Abbie, too. We couldn't see a natural blessed thing, but we finally barked our shins on a log I knew to be close to the road. Behind that log, betwixt it and the palings, was a sort of a sink place with bresh and trees growing round it. We hid in thar and boys, that was a master hiding place. Not too fur away from the house but that we could hear them talk, and with the lamp shining out the doors we could see them all wandering around, all in a puzzlement as to where we had got to. One said he knew we were thar, said he heard Abbie talking to Katty in the kitchen. Katty said he was just teched in the head, hearing booger voices. Her dry, deep voice sounded out plain as day.

"Sarch about, sarch about, if you won't take my word for it!" she'd say, and she sounded mad. She let out to give them a piece of her mind then, and all the time me and Abbie was killing ourselves laughing out there in the dark.

"O, now Katty, all we was aiming to do was to catch them home and get you to let us run some sets. Call them out now. 
Do, Katty. Tell them we won't bother them, just run a set or two, play Boston and Charlie around a little and then go home. What do you say now?"

'Ef'n you so much as offer to lay a hand on them young uns, I'll make you wish you hadn't. Long as you agree to be civil, though, I reckon you're welcome to stay and pop your heels together some. But only for as long as you stay civil."

"They all give their solemn promise not to do any thing mean to us, and she stepped out on the porch and hollered us out. They all just whooped and hollered when we come in, and they giggled and joshed us around, made sly remarks to one another for a while. Katty and Abbie flew around setting out candles and lamps and carrying the chairs out into the kitchen. We scrooched the beds back against the wall and in no time atall we were all a-stepping Charlie. Folks passing by in the road heard that good music, and they'd come by in to see why there was dancing at Katty Ritchie's and they not told about it. The ones that came in after the play got sot in its numbers stood around the wall and watched and holp us clap and sing the words.

Charlie's neat, and Charlie's sweet

And Charlie he's a dandy,

Charlie he's the very lad

That stole my striped candy.

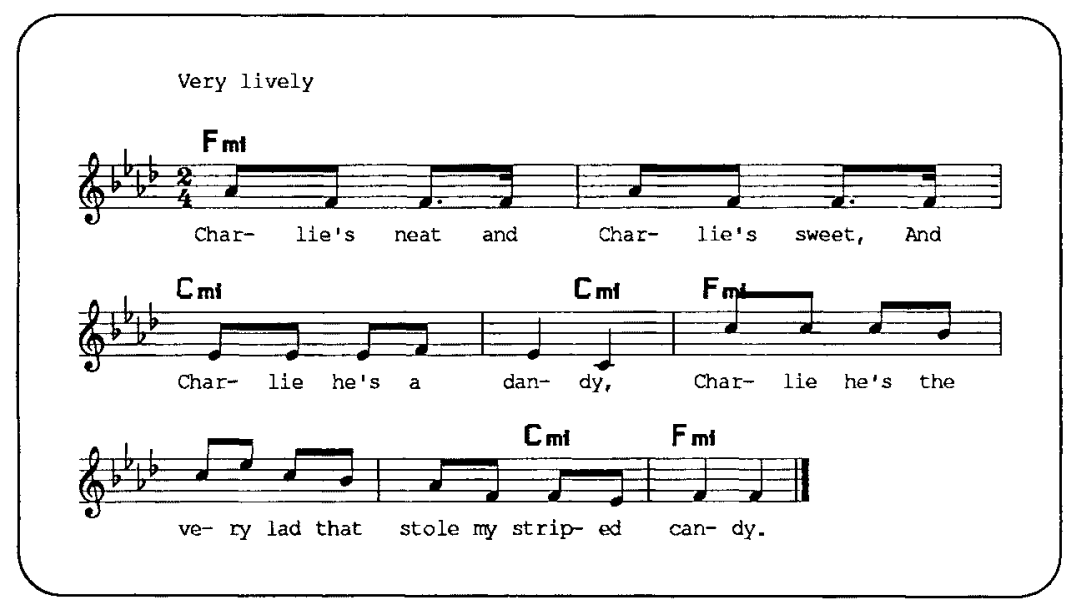


Over the river to feed my sheep And over the river, Charlie, Over the river to feed my sheep And to measure up by barley.

My pretty little pink, I once did think

I never could do without you, Since I lost all hopes of you I care very little about you.

Over the river to feed my sheep And over the river Charlie, Over the river to feed my sheep And to measure up my barley.

Don't want your wheat, don't want your cheat, And neither do I want your barley, But I'll take a little of the best you got To bake a cake for Charlie.

Over the river to feed my sheep And over the river, Charlie, Over the river to feed my sheep And to measure up my barley.

'Well,'peared like the longer we gamed, the more folks we gyarnered in. And Granny Katty, she begun to get into the sperrit of things-she allus did love merriment - and she fotch out her gingerbread stackcake that she had baked for Sunday. After I begged her awhile, she even let us drink a little bit of the elderberry wine that I had holpen her make, and she got to feeling better and better. Now, if there was anything your Granny Katty was hard against, it was making a fool out of yourself over likker, so she was keeping a lookout wherever a knot of boys gathered up to see that no corn was circulating. Once when she was passing by the only window in the housethey didn't have may windows to speak of back then, just a little hole about a foot square, face high in the hall betwixt the 
front room and the kitchen-well she passed by and she thought she heard some chaps talking out thar, so she peeped out, and sure enough, there in under the pear tree was four or five of them speaking lowly among themselves. Granny knew by the way they acted that they were up to something, so she strained her ears and she heard them a-making it up to "git Balis out and fix him up proper." Meaning to ride me on a rail, and Lord knows what else.

'Granny Katty she just sailed in to the kitchen fireplace, and grabbed her up a shovel full of firecoals, run to that window, reared back, and let them red-hot cinders fly right at the middle of that knot of boys. She was a-letting fly with her tongue, too, and wasn't nobody alive could do that better' $n$ her.

"YOU low-down villifying varmints! Ain't got the sense you'uz born with! Git from here and don't go showing your face-and-eyes on my place another time this night, any one of you! Scannle and shame!"

'Boys, them fellers never knew what hit them. They yipped and bellered and lit out in all directions, knocking the firecoals out of their hair. Thar were fellers a-leaping the palings all around the house thar for a few minutes.

'Then Granny and the rest of us had the best laugh about it. They all got the p'int that Katty meant no foolery, though. She made it plain that she had something worse to do to the next bunch that got to sneaking out under pear trees and scheming meanness. Then someone yelled:

'O, the Devil take the pear tree! Les all go to Boston! Circle up!"

'That was the last of the shivareeing that night. Abbie and me they made be the head couple, and there were so many people scrouged into the circle that it got midnight on us fore we finished up with Boston.

Good-bye girls I'm goin to Boston, Good-bye girls I'm goin to Boston, Good-bye girls I'm goin to Boston, Ear-lye in the morning. 


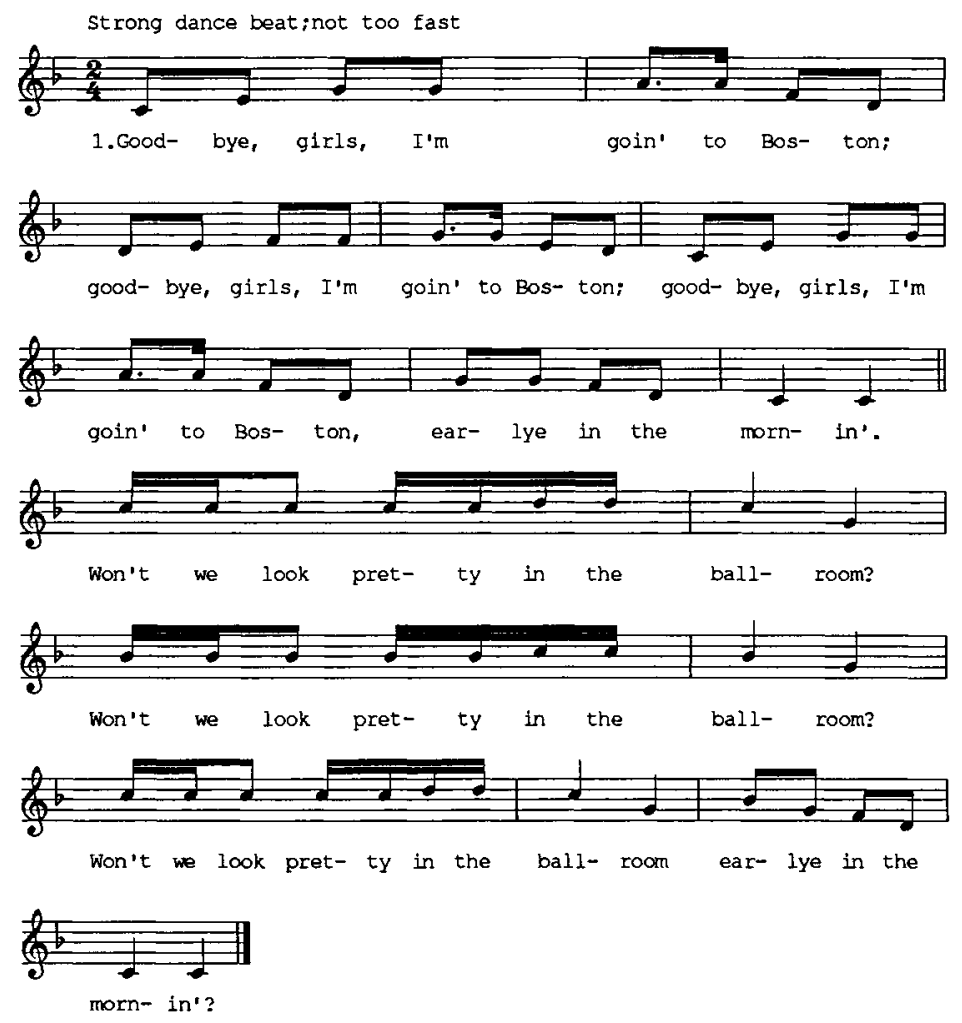

Saddle up girls and les go with them, Saddle up girls and les go with them, Saddle up girls and les go with them, Ear-lye in the morning.

Out of the way, you'll get run over, Out of the way, you'll get run over, Out of the way, you'll get run over, Ear-lye in the morning.

Rights and lefts will make it better, 
Rights and lefts will make it better, Rights and lefts will make it better, Ear-lye in the morning

Won't we look pretty in the ballroom? Won't we look pretty in the ballroom? Won't we look pretty in the ballroom Ear-lye in the morning?

Johnnie, Johnnie, goin to tell your Pappy, Johnnie, Johnnie, goin to tell your Pappy, Johnnie, Johnnie, goin to tell your Pappy Ear-lye in the morning.

Won't we look pretty in the ballroom? Won't we look pretty in the ballroom? Won't we look pretty in the ballroom Ear-lye in the morning?

'I well remember one song was sung that night. You know how at plays they'll all drap down on the floor when they're given out with games, and begin to sing, one after another? Well, when they asked John S. Combs to sing, he sung one that had for a long time been a favorite of mine, and I learnt it all from him, after that. Fore he started his song, he said he aimed to sing a pretty love song, since he reckoned that would be most to mine and Abbie's liking right now. That made everybody laugh and all the girls turn rosy in the face. You know what song it is I'm talking about; that one that starts out, "I've been a foreign lander, full seven long years or more."

I've been a foreign lander, full seven long years and more; Among the bold commanaers, where the thundering cannons roar.

I've conquered all my enemies, both all on land and sea;

It is my dearest duel, your beauty has conquered me. 

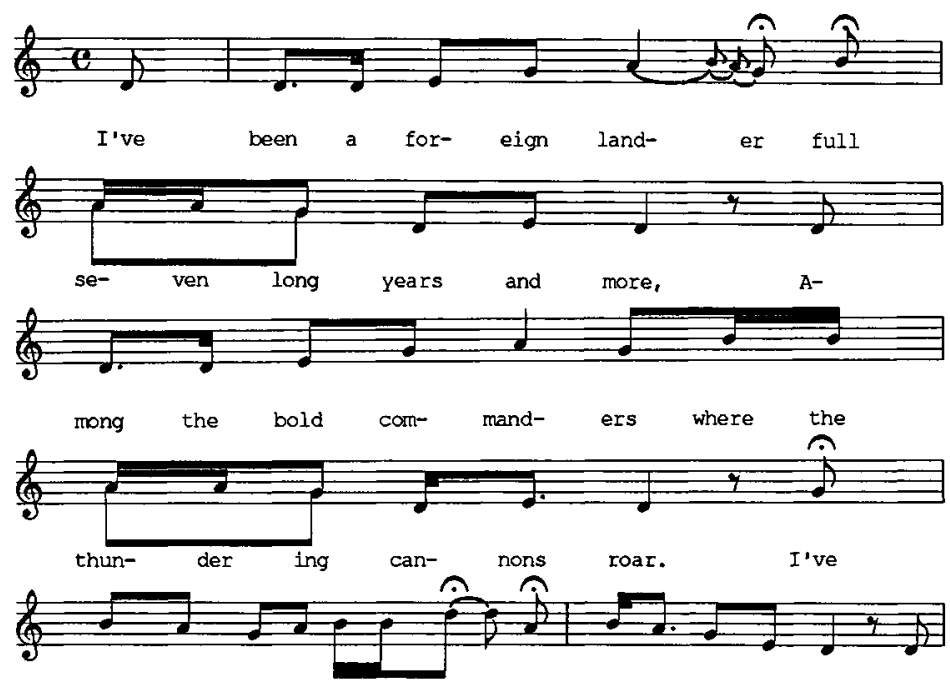

con- quered all Imy e- ne- mies, both all on land and sea, it

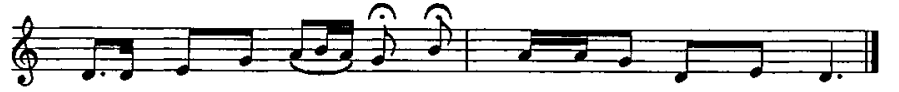

is IIy dear- est du- el, your beau- ty has con- quered me.

If I should build a ship my love, without the wood of tree, That ship would burst asunder if I prove false to thee. If ever I prove false my love, the elements will turn, The fire will freeze to ice, my love, the sea will rage and burn.

Don't you remember Queen Ellen, all in her flowery reign, As she walked out of her paradise, to cleanse the golden chain?

Her beauty and behavior, none with her could compare, But you my dearest darling, are more divinely fair.

I wish I was a turtledove, just fluttering from my nest; I'd sing so clear in the morning, with the dew all on my breast; 
So sweetly would be the music, so doleful and sad the tune, I'd sing so clear in the morning in the beautiful month of June.

I wish I was ten thousand mile, all on some lonesome shore, Or among the rocky mountains, where the wild beasts howl and roar.

The lark, the lilly owl, the eagle, and the little swallow too, I would give them all, my dearest love, if I was married to you.

'Lordie, now ain't it quare how things will come back to you so plain like that! I hain't thought of that shivaree night in many a long year now, and still and all it's like it just now happened. Fifty year ago, fifty year, little doney-gal. What do you think of that?

'Thirteen out of fourteen young uns all raised up grown, all good girls and boys, all turned out like we hoped they would, and better, only none of the girls growed to be as pretty as their $\mathrm{ma}$, and I guess I'm better-looking than any of the boys!

'I recollect now even to the end of that there party. Granny Katty said one more song, or game, whichever we would choose. Well, you know a game can allus outlast a song, don't matter how many verses a song has. We'uz all feeling lovey anyhow after all the sweet singing, so we played a kissing game, and Granny she j'ined in. Fact of the matter I believe she was the one that led off "Maria."

I wonder where Maria's gone,

I wonder where Maria's gone,

I wonder where Maria's gone,

Ear-lye in the morning.

Guess she's gone where I can't go,

Guess she's gone where I can't go,

Guess she's gone where I can't go,

Ear-lye in the morning. 
52 Oral Tradition

Yonder she comes and howdy-do!

Yonder she comes and howdy-do!

Yonder she comes and howdy-do!

Take a sweet kiss and pass on through!

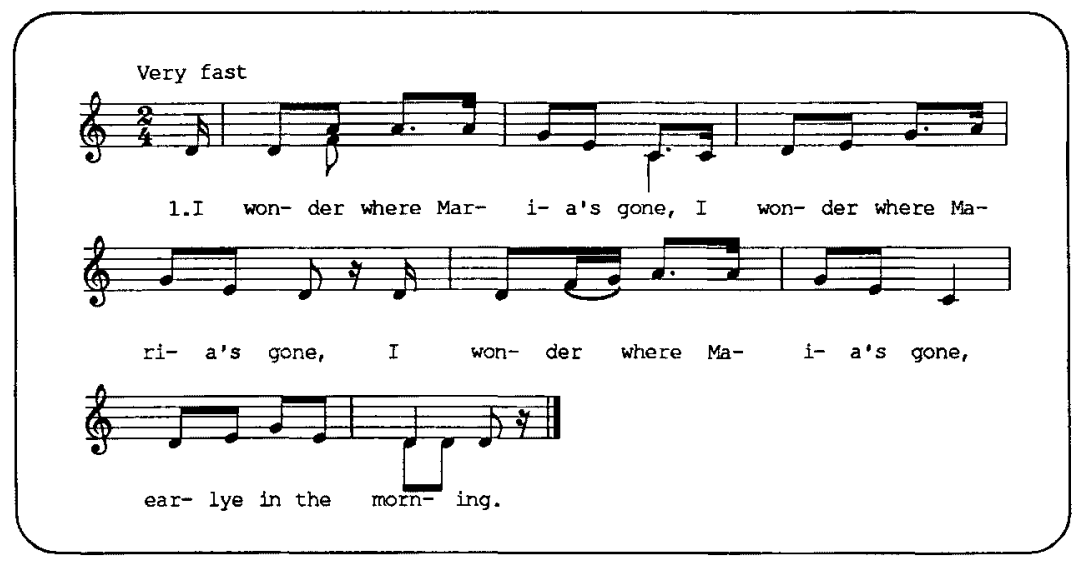

'Then they finally all left out, and Katty flaxed about like the Devil was atter her, blowing out lights east and west to save waste. Did you think that night - thirteen young uns raised up grown! Reckon we done our share for this old world, Abbie. Reckon we ought to be thankful to the good Lord that we're still alive after fifty years to tell the tale!' 


\section{Singing Family of the Cumberlands}

1. What was the occasion that prompted the children to find out about Mom and Dad's courtship?

2. Describe Abbie's first meeting with Balis.

3. When Abbie and Balis were married, they were given an infare and a shivaree. An infare is a wedding supper, and a shivaree is a mock serenade with kettles, pots, and horns. What marriage customs do we have today that may have evolved from these two customs?

4. According to Cratis Williams' essay on mountain speech in Chapter 1, mountaineers have their own dialect just as New Englanders, Southerners, and many others have. Find dialectical expressions in this story which vary from standard English. 


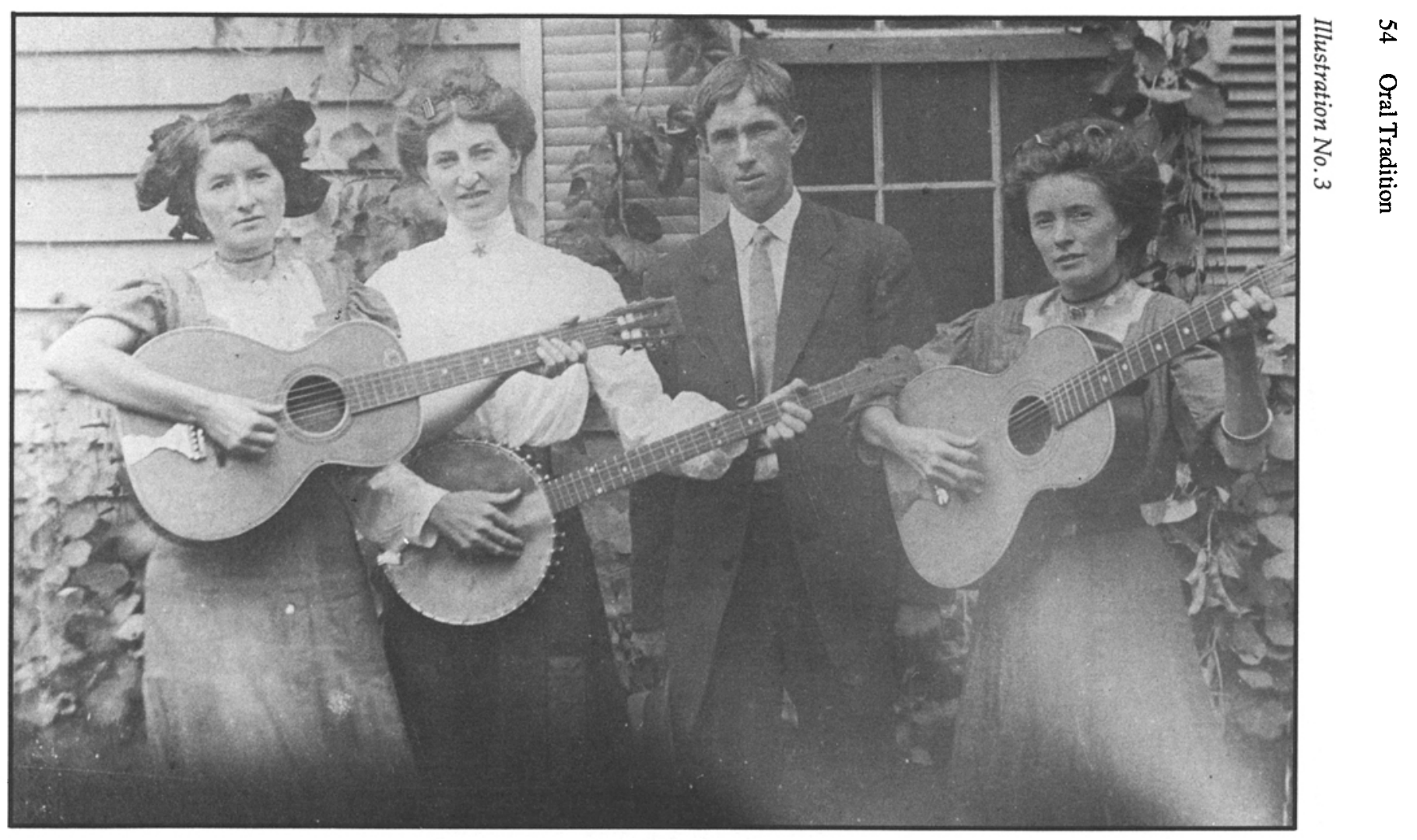




\section{THE CARTER FAMILY}

In July of 1927 the Carter Family of Maces Springs, Virginia-A.P., his wife Sara, and her cousin Maybelle, who was married to A.P.'s brother-journeyed to Bristol on the Tennessee-Virginia line to meet Ralph Peer, Victor Records' country music scout.

Here are Sara's words about that day. "We made three records. 'Single Girl, Married Girl' tipped it off."

\section{Single Girl, Married Girl}

Single girl, single girl, she's going dressed so fine, Oh, she's going dressed so fine;

Married girl, married girl, she wears just any kind. Oh, she wears just any kind.

Single girl, single girl, she goes to the store and buys, $\mathrm{Oh}$, she goes to the store and buys;

Married girl, married girl, she rocks the cradle and cries, $\mathrm{Oh}$, she rocks the cradle and cries.

Single girl, single girl, she's going where she please; Oh, she's going where she please; 
Married girl, married girl, baby on her knee, $\mathrm{Oh}$, baby on her knee.

\section{Single Girl, Married Girl}

1. Do you agree with the message of this song? Explain.

2. Could the song apply to boys as well as girls? Why or why not?

3. What advantages do married girls have that the song fails to point out? 


\section{JOHN HENRY}

This is one of the most popular American folk songs. It tells of the legendary steel-driving man who died with a hammer in his hand.

John Henry went upon the mountain

His hammer was striking fire.

But the mountain was too tall, John Henry was too small So he laid down his hammer and he died, Lord, Lord, Laid down his hammer and he died.

John Henry went into the tunnel Had his captain by his side.

The last words that John Henry said:

Bring me a cool drink of water 'fore I die, Lord, Lord, Cool drink of water 'fore I die.

John Henry had a little woman And her name was Polly Ann John Henry took sick and he had to go to bed Polly drove steel like a man, Lord, Lord, Polly drove steel like a man. 
Talk about John Henry as much as you please Say and do all that you can.

There never was born in the United States

Never such a steel-driving man, Lord, Lord,

Never such a steel-driving man, Lord, Lord,

John Henry told his captain:

I want to go to bed.

Lord, fix me a pallet, I want to lay down, Got a mighty roaring in my head, Lord, Lord, Mighty roaring in my head.

They took John Henry to the graveyard And they buried him under the sand.

Now every locomotive comes a-roaring by

Says: Yonder lies a steel-driving man, Lord, Lord, Yonder lies a steel-driving man.

\section{"John Henry"}

1. John Henry is referred to as a steel-driving man. What does this mean?

2. What was John Henry's job? When he went upon the mountain, what did he do with his hammer?

3. What does this song say about dedication? Is this the main idea of the song? Be able to defend your answer with proof from the song. 


\section{GEORGE WASHINGTON HARRIS (1814-1869)}

Born in Pennsylvania, George Washington Harris moved to Knoxville, Tennessee, at the age of five. After limited schooling, he was apprenticed to a jeweler. Then he became captain of the first regularly-scheduled steamboat out of Knoxville while he also advertised himself as "a craftsman in the metals generally." Later he became a railroad conductor.

In 1867, Harris published his Sut Lovingood's Yarns, narrated by an unpolished but good-natured Tennessee mountaineer. Comic, sometimes bawdy, and full of dialect, these yarns spring from a tradition in mountain storytelling, "the big lie," an exaggeration designed to make the listener laugh. But Harris was more than a comedy writer. His stories poke fun at society's most respected institutions-marriage, the church, and the government. Sut Lovingood is not above exposing human nature's dark or weak side with his antics. By making us laugh at ourselves and our society, Harris attempts to instruct as well as entertain. "Old Skissim's Middle Boy," which follows, is about a devilish trick Sut played when he was a young boy.

\section{Old Skissim's Middle Boy}

When I war a littil over half grown, hed sprouted my tail feathers, an' wer beginnin tu crow, thar wer a livin in the neigh- 
borhood a dredful fat, mean, lazy boy, 'bout my age. He wer the middil son ove a ole lark, name Skissim. He tinkered ontu ole clocks, an' spinin wheels, et lye hominy, an' exhortid at meetin fur a livin, while this middil boy ove hisen, did the sleepin fur the hole famurly. He cud beat a hog an' a hungry dorg eatin, $\mathrm{an}^{\prime}$ then beat his eatin wif his sleepin, es bad es his eatin beat the eatin ove a rat, arter bein shut in a church, ur a snake in a jug wif no mouf tu hit. They waked him tu eat, an' then hed tu wake him agin tu make him quit eatin; waked him tu go tu the spring, an' waked him tu start back agin; waked him tu say his prayers, an' waked him tu stop sayin 'em. In fac they wer allers a-wakin him, an' he wer allers a-goin tu sleep agin. Ole Skissim waked 'im wif a waggin whip, an' a buckshot in the cracker, what he toted apupus. His mam waked him wif the tea-kittil an' scaldin warter. Bof the buck-shot cracker $a^{\prime}$ ' the warter los tar vartu et las, an' they jis' gin him over tu onaindin sleepin, an' onmitigated hardness ove hed. Charley Dickins's son, the fat boy, mout been es ni kin tu him es a secund cuzzin, ef his mam wer a pow' ful wakeful 'oman.

I hedn't foun' out then, sartinly, that I wer a natr'1 born durnd fool. I sorter suspishioned hit, but still hed hopes. So I wer fool enuf tu think I wer smart enuff tu break him frum snoozin all the time, so I lay wake ove nites fur a week, fixin the way tu du hit; an' that minds me tu tell yu what I thinks ove plannin an' studdyin: hit am ginerly no count. All pends, et las' on what yu dus an' how yu kerries yursef at the moment ove ackshun. Sarcumstances turn about pow'ful fas', an' all yu kin du is tu think jis' es fas es they kin turn, an' jis' es they turn, an' ef yu du this, I'm durned ef yu don't git out sumhow. Long studyin am like preparin a supply ove warter intu a wum hole barril, tu put out fire: when the fire dus cum, durn'd ef yu don't hev tu hustil roun pow'ful fas', an' git more warter, fur thar's nun in the barril. But es I wer a-tellin yu, I studied out at las' a plan what I thort wud wake the devil; an' I sot in tu kerrin hit out.

The ole man Skissim an' his wife went tu a nite meetin, and tuck the ballance ove his ur rather her brats-a feller shu'd allers 
be pow'ful keerful in speakin on that pint. I'se allers hearn that hit tuck a mons' us wise brat to know hits daddy, an' I thinks hit takes a wiser daddy tu know his own brats. Dad never wud speak sartin bout eny ove our famerly but me, an' he counted fur that by sayin I wer by a long shot tu cussed a fool tu belong tu enybody else, so I am a Lovingood. My long laigs sumtimes sorter bothers me, but then mam tuck a pow'ful skeer et a sanhill crane a-sittin on a peel'd well-pole, an she out-run her shadder thuty yards in cumin half a mile. I speck I owes my laigs an' speed tu that sarcumstance an' not tu eny fraud on mam's part.

Well, they went tu nite meetin an' lef him in the kitchin fas' asleep, belevin tu fine him right thar when they cum back: but they wer mistaken'd that pop, fur when they cum they foun the widest awake boy ever born'd in that ur eny uther house, ur outen doors either, an' es tu bein rite thar he warn't by a durn'd site; he wer here, thar, an' every whar, et the same time, an' ef he hed any apertite fur vittils jis' then, he didn't hang out his sign, that I cud see.

They lef him sittin ontu a split-bottom cheer, plum asleep all over, even tu his ole hat. I tuck about thuty foot ove clothes line, an' tied him tu the cheer by his neck, body, an' arms, levin his laigs loose. He looked sorter like the Lion in the spellinbook, when the rat wer a-cuttin a fish net off ove him. That wern't a skeer'd rat, wer he? I hed him safe now tu practize on, an' I sot in tu duin hit, sorter this way: I painted his face the culler ove a nigger coalburner, scept a white ring roun his eyes; an' frum the corners ove his mouf, sorter downards, slouchwise, I lef a white strip. Hit make his mouf look sorter like ontu a hoss track an' ni ontu es big. He wer a fine picter tu study, ef your mind wer fond ove skeery things. He look't savidge es a sot steel trap, baited wif asnick, an wer jis' fit fur tresun, straterjim, an' tu spile things. Tu this day, when I dreams ove the devil, dad, Passun Bullin, an' uther orful oppressive things, that infunel boy, es he look't that nite, am durnd intermitly mix't wif the hole ove em. I speck he's dead 'is the reason ove hit.

I screw'd ontu each ove his years a par ove iron hanvices, 
what his dad squeezed ole clocks, an' crac't warnuts wif, an' they hung down like over-grow'd year-rings; I tied a gridiron tu wun ankil, an' a par ove fire-tongs tu tuther; I pour'd a bottil ove groun red-pepper down his back, onder his shut; I turn'd loose a pint ove June-bugs, what I kotch apupus, into his buzzum, an' buttoned em up; I tied a baskit full ove fire crakers tu the cheer back, tu his har, an' tu his wrists; I button'd up a big grey-whisker'd aggravated ole rat, tied wif a string intu the slack ove his britches; tuther aind ove the string wer fas' ontu his gallus button, an the rat, like all the res' ove that tribe, imejuntly sot in cuttin his way out; but owin tu his parvarse nater ur the darkness ove the place, he sot in tu cuttin the wrong way; he wer a workin towards the back-bone, an' furder frum the britches, every cut. I learnt this fac' frum the cheer risin frum the flure, an' fallin agin jis' tu rise imejuntly a littil higher, an' sum souns, a mixtry ove snort, snore, grunt, an' groan, which he wer beginin tu isoo tolabil fas, an' gettin louder every bounce ove the cheer, an' becumin more like ontu a howl every pop. In the beginin ove his oneasines he dream'd ove wagin whip, nex' he dream'd ove a tea-kittil es big es a still, an lots ove bilin warter, an' nex he drempt ove bof ove 'em; an' now he wer a dreamin that the tea-kittil wer a steam ingine, a drivin the waggin whip, an' a cottin gin wif red hot saws fifteen hundred licks a minit, an' that he wer in the cottin hopper.

I now thot hit ni ontu the proper time tu tetch the crackers, so es tu hev everything bar hits shar in the kontemplated cummin waknin. An' I did hit. The fust handful ur so gwine off help'd, wif the industry ove that energetic ole rat, the sarchin ove the red pepper, an' the permiskus scratchin roun ove the bugs, tu begin tu wake him sorter gradually, a littil faster nor light bread rises, an' a littil slower then a yeathquake wakes weazels. A few hundred more gwine off, still hevin the rat, pepper, an' insex tu back em, got him wide enuf awake tu bleve that he wer threatened wif sum orful pussonal calamerty, what wanted pow'ful quick work on his part tu dodge. He wer awake now all over, even tu his durnd ole hat, an' he show'd hit in es meny ways es a cat dus, lock'd up in a empty room wif 
a strange an' interprisin big dorg.

He grabbed the fire shovil, an' bounc'd half bent (the cheer kep him frum straitin up) all over that kitchen, a strikin overhanded, onder-handed, up-handed, down-handed, an' lefhanded, at every 'spishus shadder he seed. He fit by the light ove ten million sparks; he wer es active as a smut-mercheen in full blast, an' every grain ove wheat a spark. An' he wer a hollerin everything anybody ever did holler in dredful tribulashun ove spirit, even tu, "Now I lay me down tu sleep," an' "Gloree."

When I'se in trubbil, skeer, ur tormint, I dus but wun thing, $a^{\prime}$ ' that's onresistabil, onekeled, an' durn'd fas' runnin, an' I jis' keeps at hit till I gits cumfort. Now his big idear onder nise an' varigated hurtin wer tu fite, an' keep on a-fitin, ontil peace ove mine cum. I never seed sich keryins on in all my born'd days. He made more fuss, hit more licks at more things, wer in more places, an' in more shapes, in a shorter time, then eny mortal auctioneer cud tell ef he hed es meny tungs es a baskit full ove buckils. Every now an' then he'd gin his head a vishus, vigrus shake, an' the han-vices wud hit him fore an' arter, till his skull rattiled like ontu a ole gourd.

The ole Skissim an' his tribe cum home frum meetin, an' hearin the onyeathly riot, thort sumbody hed opened a dorggery in thar kitchen an' that a neighborhood fite were gwine on, an' every feller's dorg along. They rushed in tu drive out the crowd, an' capter the whisky, an' a durnder more misfortinit mistake never wer make by a man, 'oman, an' a string ove fifteen brats, since ole Bill Shivers went fur a runnin threshin-meesheen tu smash hit, thinkin hit wer a big musickbox.

The ole hoss hisse'f imejuntly cum in contack wif a holesum knockdown, what calm'd him intu sumthin mons'us like sleep, fur about a minit. Now a heap ove things ken happen in a minit, purtickerly ef thar's sumbody who hes sot his hole soul tu the bisiness ove makin em happen. Hit wer so in that kitchen. Agin the ole feller cum tu, the ole 'oman wer knocked hed fust intu the meal-barril, whar she wer breathin more meal nur air, an' she wer snortin hit up over the aidges ove the barril like hit wer 
a fountin playin corn meal. The ol'est gal wer sturn fus' in a soap-kittil, an' she wor a-makin suds outen sum ove hit. The nex' wun wer laingthwise belly down in the pot corner. The biggest boy wer whar the back-log orter been, ontu his all fours a-scratchin up all the embers an' ashes, a-tryin tu cum out frum thar. Anuther cub, in a jackid wif a wun inch tail, wer knocked plum thru the tin intu the safe amung the cold vitils an' things. A littil gal, doll baby an' all, wer on the top shelf ove cup-board, amung the delf, a-screamin like a little steam whistil.

The neighbors wer a-getherin in roun the nise an' rumpus, an' not a durn'd wun hed the least idear ove what wer wrong, sceptin ove me. I onderstood hit all, durn'd fool es I is. Tu 'scape frum bein 'spishioned, I sot in tu cuttin the cheer loose es I got chances, an' a-keepin outen the range ove that flyin fire shovil, fur hit wer still spreadin hurtin an' mischief on a perpetul moshun plan. Everybody hit totch fell, an' everything hit cum agin got grief. The tin buckits look'd likedrunk men's hats. Pails hed lef' thar hoops, an' the delf war was in scrimpshuns. When he got divorced from the cheer, I tho't he'd sorter simmer down. But no sir! He got wus, an' did his work faster an' better; he wer as crazy as a bed-bug, an' as savidge as a maddorg.

I seed a-cummin, a ole widder, what wer a pow'ful pius turn'd pusson, in the same church wif ole Skissim, an' she wer the news-kerrier gineral ove the neighborhood. Folks sed that they hed a religus feelin fur each uther, what led tu meny lovefeas, wif nobody at em but tharsefs, an' wer bof doin mouns'ous well, considerin the thorn in the flesh. Sez she-

"Oh, my soul! Du tell me what hes happened! Oh lordy massy!" sed I, "hits a-happenin yet!" a-lookin orful solemn in the moonshine. Sez I, "I'll tell yu, es I knows yu won't speak ove it; fur ef hit gits out, hit mout make the pepil sorter think hard ove Mister Skissim. He cum home frum meetin plum crazy, talkin about the seventh cumandment, an' he's sot intu murderin hes folks wif a crowbar. He hes dun got his wife an' six ove the brats: thar a-lyin in thar es cold es krout; an' he's hot 
arter the rest ove em; sez he's in a hurry tu git thru, es he hes yu tu kill an' salt down afore day. Now I know by that he's turn'd durned fool."

She never sed a word, but put out fur Squir Haley's, an' swore her life agin ole Skissim, an' tuck out a warrint fur him a-chargin murder, arson, blasfemy, fleabottomry an' rape. Hit skeer'd ole Skissim ontil he run away.

By the time I got dun inlitenin the widder, that ar onquinchable boy hed the kitchen all tu hissef. Everybody wer feard tu go ni the door. Now yu cudent guess in ten year what he then went an' did. He jis' made a piller outen the cheer, an' sot intu sleepin agin. Ef ever I'se call'd on tu stop his sleepin eny more agin, I'll try a muskit an' sixteen buckshot, at jis' about ten steps.

\section{Old Skissim's Middle Boy}

1. The author uses many details and comparisons in describing Skissim's lazy boy. Find examples of his most vivid description.

2. What words of wisdom does Sut offer regarding the advantage of thinking fast?

3. Describe the trick Sut played on the lazy boy. Was he able to cure him of his laziness?

4. What did Sut tell the pious widow that resulted in her taking out a warrant for old Skissim's arrest?

5. Define dialect and discuss its importance to the humor in Harris' writing. 


\section{COMPOSITION TOPICS}

1. You will notice that a ballad is a story told in verse that is usually meant to be sung. Write a ballad about a modern hero, a sudden disaster, or a recent crime.

2. Three selections in this chapter "Tsali of the Cherokees," "Cat'n Mouse," and "The Ballad of Claude Allen" were told in story or song before they were written. Talk to your parents, grandparents, and neighbors about an interesting event that they have heard about or experienced. Turn this into a story.

\section{ACTIVITIES}

Compile a family scrapbook.

Throughout this study of Southern Appalachian literature as you complete the activities, you will be creating your own book. When you finish the study, you will have written your own story. Many of you will have Appalachian stories . But because of America's great cultural diversity, many of your stories will reflect different ethnic origins. Regardless of your individual heritage, you will be proud of your book.

Begin with a family tree. (See sample family tree on page 68.) Here you have a picture of your ancestors, those people who have helped make you what you are today. They will be the characters in your book.

Write a character sketch of your parents, grandparents, and great-grandparents whom you have known. Names and dates hardly tell the story of the real people that they are. As you interview each, you will likely hear some stories about events in each person's life. Make these stories a part of the character sketch. It's all right to get help from family members. Write 
about the following items with as much detail as you can find:

1. Physical description

2. Personality

3. Ethnic origin

4. Date and place of birth

5. Address and description of the house where this person grew up

6. Name and description of the community where this person grew up

7. Education

8. Church affiliation

9. Jobs

10. Political party

11. What this person enjoys doing

12. Health-mental and physical

13. Major accomplishments-what the person is proud of in his life

14. Valuable advice for getting along in life

Now illustrate each character sketch with a photograph of the person. Also find old photographs of each person at a younger age and include them. 


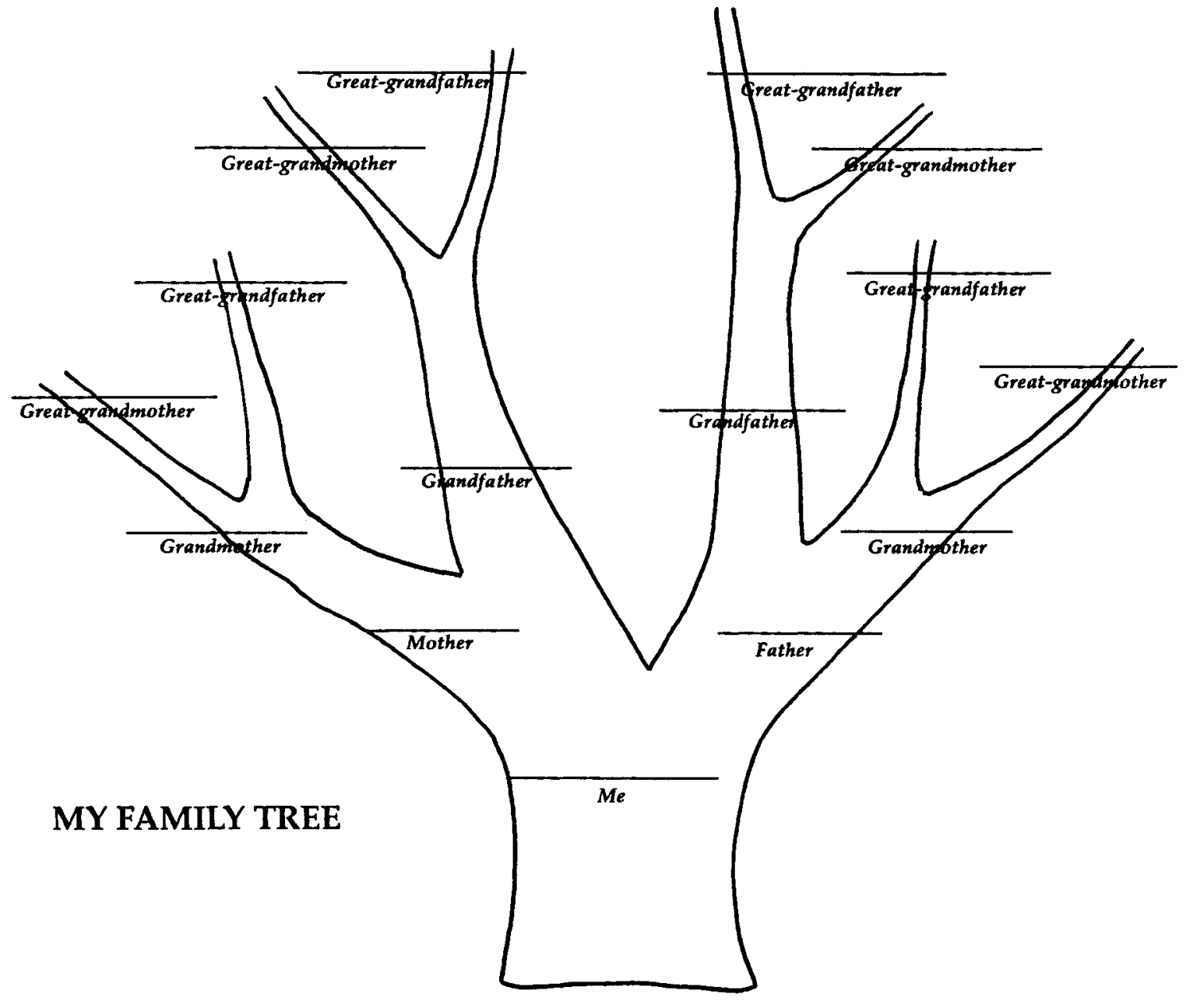




\section{CHAPTER 2}

\section{Local Color $\mathcal{E}$ the Realistic Tradition}

"Local color" means that the writer uses specific details about a locale--the native speech, dress, customs, music, and religious practices-in his works. No other group of writers has had a more profound influence on Appalachian literature than the original "local color" authors Mary Noailles Murfree and John Fox, Jr. As several scholars point out, these early writers have influenced the literature of the region right up to the present day. Most importantly, their stories shaped an image of Appalachia for the rest of America.

In The Southern Mountaineer in Fact and Fiction, Cratis Williams says that the publication in 1884 of Mary Noailles Murfree's book In the Tennessee Mountains "marks the time at which the Southern mountain people had become recognized as a people possessing their own idiosyncrasies, and not to be confused with other southern types."

Henry Shapiro carries this idea even further in his bookAppalachia on Our Mind. He points out that the local color writers have had a long-range effect on the image of Appalachia. People like Murfree and Fox published their works 
in the new, nationally circulated magazines The Atlantic Monthly, Harper's and Lippincott's. The Civil War also heightened awareness of regional differences. The war correspondents at the front served as the first local colorists. During the last three decades of the nineteenth century, the American public developed a taste for reading about the unusual, the exotic. Appalachia seemed unusual and exotic. Shapiro maintains that the early local color writers created the idea of Appalachia by presenting a consistent picture of it as a backward place inhabited by strange people. In other words, Appalachia was different from the rest of America.

Murfree and Fox use this idea of the "otherness" of Appalachia in several works. For example, "The Star in the Valley," the selection in this chapter by Murfree, focuses on an outsider's perceptions of the region and on the clash in values that this outsider brings to a remote mountain community.

Three writers in this section-Haun, Armstrong, and Still-produced works in the Realistic tradition in American literature. This tradition grew out of local color. The realists, wishing to record life as it is, refrain from philosophical interpretations of their stories. Free of romantic prettiness, realistic writing emphasizes truthful treatment of the place, the people, and the events in a story and lets us see life cut to the bone. The characters in these stories by Haun, Armstrong, and Still reveal themselves to the reader and give insight into their feelings, motives, and personalities. Because they differ from the sometimes superficial and theatrical characters created by the local colorists, they present a less romantic stereotype. 


\section{MARY NOAILLES MURFREE (1850-1922)}

Mary Noailles Murfree, born into an aristocratic family in Middle Tennessee, came to know mountain people and their ways from spending summers visiting Beersheba resort in the Cumberland Mountains. Because it seemed improper for a young lady of her social standing to write stories, she first published her work, including the piece here from the collection In the Tennessee Mountains, under the pseudonym Charles Egbert Craddock.

She was educated at the Nashville Female Academy and the Chegary Institute in Philadelphia. The University of the South awarded her a honorary Doctor of Letters in 1922.

In this story, Reginald Chevis visits a mountain community and meets a poor, uneducated girl, Celia Shaw. She intervenes in a feud and prevents bloodshed. Her heroism and high principles earn her the respect and admiration of Chevis, but only disdain from her own people.

\section{The Star in the Valley}

He first saw it in the twilight of a clear October evening. As the earliest planet sprang into the sky, an answering gleam shone red amid the glooms in the valley. A star too it seemed. And later, when the myriads of the fairer, whiter lights of a 
moonless night were all athrob in the great concave vault bending to the hills, there was something very impressive in that solitary star of earth, changeless and motionless beneath the ever-changing skies.

Chevis never tired of looking at it. Somehow it broke the spell that draws all eyes heavenward on starry nights. He often strolled with his cigar at dusk down to the verge of the crag, and sat for hours gazing at it and vaguely speculating about it. That spark seemed to have kindled all the soul and imagination within him, although he knew well enough its prosaic source, for he had once questioned the gawky mountaineer whose services he had secured as guide through the forest solitudes during this hunting expedition.

"That thar spark in the valley?" Hi Bates had replied, removing the pipe from his lips and emitting a cloud of strong tobacco smoke. "'Tain't nuthin' but the light of Jerry Shaw's house, 'bout haffen mile from the foot of the mounting. Ye pass that thar house when ye goes on the Christel road, what leads down the mounting off the Back-bone. That's Jerry Shaw's house,-that's what it is. He's a blacksmith, an' he kin shoe a horse toler'ble well when he ain't drunk, ez he mos'ly is."

"Perhaps that is the light from the forge," suggested Chevis.

"That thar forge ain't run more' $n$ half the day, let 'lone o' nights. I hev never hearn tell on Jerry Shaw a-workin' $o^{\prime}$ nights,-nor in the daytime nuther, ef he kin get shet of it. No sech no 'count critter 'twixt hyar an' the Settlemint."

So spake Chevis's astronomer. Seeing the star even through the prosaic lens of stern reality did not detract from its poetic aspect. Chevis never failed to watch for it. The first faint glinting in the azure evening sky sent his eyes to that red reflection suddenly aglow in the valley; even when the mists rose above it and hid it from him, he gazed at the spot where it had disappeared, feeling a calm satisfaction to know that it was still shining beneath the cloud curtain. He encouraged himself in this bit of sentimentality. These unique eventide effects seemed a fitting sequel to the picturesque day, passed in hunting deer, with horn and hounds, through the gorgeous autumnal forest; 
or perchance in the more exciting sport in some rocky gorge with a bear at bay and the frenzied pack around him; or in the idyllic pleasures of birdshooting with a thoroughly-trained dog; and coming back in the crimson sunset to a well-appointed tent and a smoking supper of venison or wild turkey,-the trophies of his skill. The vague dreaminess of his cigar and the charm of that bright bit of color in the night-shrouded valley added a sort of romantic zest to that keen susceptibility of impressions which Reginald Chevis considered eminently characteristic of a highly wrought mind and nature.

He said nothing of his fancies, however, to his fellow sportsman, Ned Varney, nor to the mountaineer. Infinite as was the difference between these two in mind and cultivation, his observation of both had convinced him that they were alike incapable of appreciating and comprehending his delicate and dainty musings. Varney was essentially a man of this world; his mental and moral conclusions had been adopted in a calm, mercantile spirit, as giving the best return for the outlay, and the market was not liable to fluctuations. And the mountaineer could go no further than the prosaic fact of the light in Jerry Shaw's house. Thus Reginald Chevis was wont to sit in contemplative silence on the crag until his cigar was burnt out, and afterward to lie awake deep in the night, listening to the majestic lyric welling up from the thousand nocturnal voices of these mountain wilds.

During the day, in place of the red light a gauzy little curl of smoke was barely visible, the only sign or suggestion of human habitation to be seen from the crag in all the many miles of long, narrow valley and parallel tiers of ranges. Sometimes Chevis and Varney caught sight of it from lower down on the mountain side, whence was faintly distinguishable the little log-house and certain vague lines marking a rectangular inclosure; near at hand, too, the forge, silent and smokeless. But it did not immediately occur to either of them to theorize concerning its inmates and their lives in this lonely place; for a time, not even to the speculative Chevis. As to Varney, he gave his whole mind to the matter in hand,-his gun, his dog, his 
game,-and his note-book was as systematic and as romantic as the ledger at home.

It might be accounted an event in the history of that log-hut when Reginald Chevis, after riding past it eighty yards or so, chanced one day to meet a country girl walking toward the house. She did not look up, and he caught only an indistinct glimpse of her face. She spoke to him, however, as she went by, which is the invariable custom with the inhabitants of the sequestered nooks among the encompassing mountains, whether meeting stranger or acquaintance. He lifted his hat in return, with that punctilious courtesy which he made a point of according to persons of low degree. In another moment she had passed down the narrow sandy road, overhung with gigantic trees, and, at a deft, even pace, hardly slackened as she traversed the great log extending across the rushing stream, she made her way up the opposite hill, and disappeared gradually over its brow.

The expression of her face, half-seen though it was, had attracted his attention. He rode slowly along, meditating. "Did she go into Shaw's house, just around the curve of the road?" he wondered. "Is she Shaw's daughter, or some visiting neighbor?"

That night he looked with a new interest at the red star, set like a jewel in the floating mists of the valley.

"Do you know," he asked of Hi Bates, when the three men were seated, after supper, around the camp-fire, which sent lurid tongues of flame and a thousand bright sparks leaping high in the darkness, and illumined the vistas of the woods on every side, save where the sudden crag jutted over the valley,"Do you know whether Jerry Shaw has a daughter,-a young girl?"

"Ye-es," drawled Hi Bates, disparagingly, "he hev."

A pause ensued. The star in the valley was blotted from sight; the rising mists had crept to the verge of the crag; nay, in the undergrowth fringing the mountain's brink, there were softly clinging white wreaths.

"Is she pretty?" asked Chevis. 
"Waal, no she ain't," said Hi Bates, decisively. "She's a pore, no 'count critter." Then he added, as if he were afraid of being misapprehended, "Not ez thar is any harm in the gal, ye onderstand. She's a mighty good, soft-spoken, quiet sort o' gal, but she's a pore, white-faced, slim little critter. She looks like she hain't got no sort'n grit in her. She makes me think o' one them slim little slips $o^{\prime}$ willow every time nor I sees her. She hain't got long ter live, I reckon," he concluded, dismally.

Reginald Chevis asked him no more questions about Jerry Shaw's daughter.

Not long afterward, when Chevis was hunting through the deep woods about the base of the mountain near the Christel road, his horse happened to cast a shoe. He congratulated himself upon his proximity to the forge, for there was a possibility that the blacksmith might be at work; according to the account which Hi Bates had given of Jerry Shaw's habits, there were half a dozen chances against it. But the shop was at no great distance and he set out to find his way back to the Christel road, guided by sundry well-known landmarks on the mountain side: certain great crags hanging above the tree-tops, showing in grander sublimity through the thinning foliage, or beetling bare and grim; a dismantled and deserted hovel, the red-berried vines twining amongst the rotting logs; the full flow of a tumultuous stream making its last leap down a precipice eighty feet high, with yeasty, maddening waves below and a rainbowcrowned crystal sheet above. And here again the curves of the woodland road. As the sound of the falling water grew softer and softer in the distance, till it was hardly more than a drowsy murmur, the faint vibrations of a far-off anvil rang upon the air. Welcome indeed to Chevis, for however enticing might be the long rambles through the redolent October woods with dog and gun, he had no mind to tramp up the mountain to his tent, five miles distant, leading the resisting horse all the way. The afternoon was so clear and so still that the metallic sound penetrated far through the quiet forest. At every curve of the road he expected to see the log-cabin with its rail fence, and beyond the low-hanging chestnut-tree, half its branches resting 
upon the roof of the little shanty of a blacksmith's shop. After many windings a sharp turn brought him full upon the humble dwelling, with its background of primeval woods and the purpling splendors of the western hills. The chickens were going to roost in a stunted cedar-tree just without the door; an incredibly old man, feeble and bent sat dozing in the lingering sunshine on the porch; a girl, with a pail on her head, was crossing the road and going down a declivity toward a spring which bubbled up in a cleft of the gigantic rocks that were piled one above another, rising to a great height. A mingled breath of cool, dripping water, sweet-scented fern, and pungent mint greeted him as he passed it. He did not see the girl's face, for she had left the road before he went by, but he recognized the slight figure, with that graceful poise acquired by the prosaic habit of carrying weights upon the head, and its lithe, swaying beauty reminded him of the mountaineer's comparison,- a slip of willow.

And now, under the chestnut-tree, in anxious converse with Jerry Shaw, who came out hammer in hand from the anvil, concerning the shoe to be put on Strathspey's left fore-foot, and the problematic damage sustained since the accident. Chevis's own theory occupied some minutes in expounding, and so absorbed his attention that he did not observe, until the horse was fairly under the blacksmith's hands, that, despite Jerry Shaw's unaccustomed industry, this was by no means a red-letter day in his habitual dissipation. He trembled for Strathspey, but it was too late now to interfere. Jerry Shaw was in that stage of drunkenness which is greatly accented by an elaborate affectation of sobriety. His desire that Chevis should consider him perfectly sober was abundantly manifest in his rigidly steady gait, the preternatural gravity in his bloodshot eyes, his sparingness of speech, and the earnestness with which he enunciated the acquiescent formulae which had constituted his share of the conversation. Now and then, controlling his faculties by a great effort, he looked hard at Chevis to discover what doubts might be expressed in his face concerning the genuineness of this staid deportment; and Chevis presently found it best to af- 
fect too. Believing that the blacksmith's histrionic attempts in the role of sober artisan were occupying his attention more than the paring of Strathspey's hoof, which he held between his knees on his leather apron, while the horse danced an animated measure on the other three feet, Chevis assumed an appearance of indifference, and strolled away into the shop. He looked about him, carelessly, at the horseshoes hanging on a rod in the rude aperture that served as a window, at the wagon-tires, the plowshares, the glowing fire of the forge. The air within was unpleasantly close, and he soon found himself again in the door-way.

"Can I get some water here?" he asked, as Jerry Shaw reentered, and began hammering vigorously at the shoe destined for Strathspey.

The resonant music ceased for a moment. The solemn, drunken eyes were slowly turned upon the visitor, and the elaborate affectation of sobriety was again obtrusively apparent in the blacksmith's manner. He rolled up more closely the bluechecked homespun sleeve from his corded hammer-arm, twitched nervously at the single suspender that supported his copper-colored jeans trousers, readjusted his leather apron hanging about his neck, and, casting upon Chevis another glance, replete with a challenging gravity, fell to work upon the anvil, every heavy and well-directed blow telling with the precision of machinery.

The question had hardly been heard before forgotten. At the next interval, when he was going out to fit the horse, Chevis repeated his request.

"Water, did ye say?" asked Jerry Shaw, looking at him with narrowing eyelids, as if to shut out all other contemplation that he might grapple with this problem. "Thar's no fraish water hyar, but ye kin go yander ter the house an ax fur some; or," he added, shading his eyes from the sunlight with his broad, blackened hand, and looking at the huge wall of stone beyond the road, "ye kin go down yander ter the spring, an' ax that thar gal fur a drink."

Chevis took his way, in the last rays of sunshine, across the 
road and down the declivity in the direction indicated by the blacksmith. A cool gray shadow fell upon him from the heights of the great rocks, as he neared them; the narrow path leading from the road grew dank and moist, and presently his feet were sunk in the still green and odorous water-loving weeds, the clumps of fern, and the pungent mint. He did not notice the soft verdure; he did not even see the beautiful vines that hung from earth-filled niches among the rocks, and lent to their forbidding aspect something of a smiling grace; their picturesque grouping, where they had fallen apart to show this sparkling fountain of bright up-springing water, was all lost upon his artistic perceptions. His eyes were fixed on the girl standing beside the spring, her pail filled, but waiting, with a calm, expectant look on her face, as she saw him approaching.

No creature could have been more coarsely habited: a green cotton dress, faded to the faintest hue; rough shoes, just visible beneath her skirts; a dappled gray and brown calico sun-bonnet, thrown aside on a moss-grown boulder near at hand. But it seemed as if the wild nature about her had been generous to this being toward whom life and fortune had played the niggard. There were opaline lights in her dreamy eyes which one sees nowhere save in sunset clouds that brood above dark hills; the golden sunbeams, all faded from the landscape, had left a perpetual reflection in her bronze hair; there was a subtle affinity between her and other pliant, swaying, graceful young things, waving in the mountain breezes, fed by the rain and dew. She was hardly more human to Chevis than certain lissome little woodland flowers, the very name of which he did not know, pure white, star-shaped, with a faint green line threading though each of the five delicate petals; he had seen them embellishing the banks of lonely pools, or growing in dank, marshy places in the middle of the unfrequented road, where perhaps it had been mended in a primitive way with a few rotting rails.

"May I trouble you to give me some water?" asked Chevis, prosaically enough. She neither smiled nor replied. She took the gourd from the pail, dipped it into the lucent 
depths of the spring, handed it to him, and stood awaiting its return when he should have finished. The cool, delicious water was drained, and he gave the gourd back. "I am much obliged," he said.

"Ye're welcome," she replied, in a slow, singing monotone. Had the autumn winds taught her voice that melancholy cadence?

Chevis would have liked to hear her speak again, but the gulf between his station and hers-so undreamed of by her (for the differences of caste are absolutely unknown to the independent mountaineers), so patent to him - could be bridged by few ideas. They had so little in common that for a moment he could think of nothing to say. His cogitation suggested only the inquiry, "Do you live here?" indicating the little house on the other side of the road.

"Yes," she chanted in the same monotone, "I lives hyar." She turned to lift the brimming pail. Chevis spoke again: "Do you always stay at home? Do you never go anywhere?"

Her eyes rested upon him, with a slight surprise looking out from among their changing lights. "No," she said, after a pause; "I hev no call to go nowhar ez I knows on."

She placed the pail on her head, took the dappled sun-bonnet in her hand, and went along the path with the assured, steady gait and the graceful backward poise of the figure that precluded the possibility of spilling a drop from the vessel.

He had been touched in a romantic way by the sweet beauty of this little woodland flower. It seemed hard that so perfect a thing of its kind should be wasted here, unseen by more appreciative eyes than those of bird, or rabbit, or the equally uncultured human beings about her; and it gave him a baffling sense of the mysterious injustice of life to reflect upon the difference in her lot and that of others of her age in higher spheres. He went thoughtfully through the closing shadows to the shop, mounted the re-shod Strathspey, and rode along the rugged ascent of the mountain, gravely pondering on worldly inequalities.

He saw her often afterward, although he spoke to her again 
but once. He sometimes stopped as he came and went on the Christel road, and sat chatting with the old man, her grandfather, on the porch, sunshiny days, or lounged in the barn-like door of Jerry Shaw's shop talking to the half-drunken blacksmith. He piqued himself on the readiness with which he became interested in these people, entered into their thoughts and feelings, obtained a comprehensive idea of the machinery of life in this wilderness,-more complicated than one could readily believe, looking upon the changeless face of the wide, unpopulated expanse of mountain ranges stretching so far beneath that infinite sky. They appealed to him from the basis of their common humanity, he thought, and the pleasure of watching the development of the common human attributes in this peculiar and primitive state of society never palled upon him. He regarded with contempt Varney's frivolous displeasure and annoyance because of Hi Bates's utter insensibility to the difference in their social position, and the necessity of either acquiescing in the supposititious equality or dispensing with the invaluable services of the proud and independent mountaineer; because of the patois of the untutored people, to hear which, Varney was wont to declare, set his teeth on edge; because of their narrow prejudices, their mental poverty, their idle shiftlessness, their uncouth dress and appearance. Chevis flattered himself that he entertained a broader view. He had not even a subacute idea that he looked upon these people and their inner life only as picturesque bits of the mental and moral landscape; that it was an aesthetic and theoretical pleasure their contemplation afforded him; that he was as far as ever from the basis of common humanity.

Sometimes while he talked to the old man on the sunlit forch, the "slip o' willow" sat in the door-way, listening too, but never speaking. Sometimes he would find her with her father at the forge, her fair, ethereal face illumined with an alien and fluctuating brilliancy, shining and fading as the breath of the fire rose and fell. He came to remember that face so well that in a sorry sketch-book where nothing else was finished, there were several laborious pages lighted up with a faint reflection 
of its beauty. But he was as much interested perhaps, though less poetically, in that massive figure, the idle blacksmith. He looked at it all from an ideal point of view. The star in the valley was only a brilliant, set in the night landscape, and suggested a unique and pleasing experience.

How should he imagine what luminous and wistful eyes were turned upward to where another star burned,- - the light of his campfire on the crag; what pathetic, beautiful eyes had learned to watch and wait for that red gleam high on the mountain's brow,-hardly below the stars in heaven it seemed! How could he dream of the strange, vague, unreasoning trouble with which his idle comings and goings had clouded that young life, a trouble as strange, as vague, as vast, as the limitless sky above her.

She understood him as little. As she sat in the open doorway, with the flare of the fire behind her, and gazed at the red light shining on the crag, she had no idea of the heights of worldly differences that divided them, more insurmountable than precipices and flying chutes of mountain torrents, and chasms and fissures of the wild ravine: she knew nothing of the life he had left, and of its rigorous artificialities and gradations of wealth and estimation. And with a heart full of pitiable unrealities she looked up at the glittering simulacrum of a star on the crag, while he gazed down on the ideal star in the valley.

The weeks had worn deep into November. Chevis and Varney were thinking of going home; indeed, they talked of breaking camp day after to-morrow, and saying a long adieu to wood and mountain and stream. They had had an abundance of good sport and a surfeit of roughing it. They would go back to town and town avocations invigorated by their holiday, and taking with them a fresh and exhilarating recollection of the forest life left so far behind.

It was near dusk, on a dull, cold evening, when Chevis dismounted before the door of the blacksmith's little log-cabin. The chestnut-tree hung desolate and bare on the eaves of the forge; the stream rushed by in swift gray whirlpools under a 
sullen gray sky; the gigantic wall of broken rocks loomed gloomy and sinister on the opposite side of the road,--not so much as a withered leaf of all their vines clung to their rugged surfaces. The mountains had changed color: the nearest ranges were black with the myriads of the grim black branches of denuded forest; far away they stretched in parallel lines, rising tier above tier, and showing numberless gradations of a dreary, neutral tint, which grew ever fainter in the distance, till merged in the uniform tone of the sombre sky.

Indoors it was certainly more cheerful. A hickory fire dispensed alike warmth and light. The musical whir of a spinningwheel added its unique charm. From the rafters depended numberless strings of bright red pepper-pods and ears of popcorn; hanks of woolen and cotton yarn; bunches of medicinal herbs; brown gourds and little bags of seeds. On rude shelves against the wall were ranged cooking utensils, drinking vessels, etc., all distinguished by that scrupulous cleanliness which is a marked feature of the poor hovels of these mountaineers, and in striking contrast to the poor hovels of lowlanders. The rushbottomed chairs, drawn in a semicircle before the rough, ill-adjusted stones which did duty as hearth, were occupied by several men, who seemed to be making the blacksmith a prolonged visit; various members of the family were humbly seated on sundry inverted domestic articles, such as wash-tubs, and splint-baskets made of white oak. There was circulating among Jerry Shaw's friends a flat bottle, facetiously denominated "tickler," readily emptied, but as readily replenished from a keg in the corner. Like the widow's cruse of oil, that keg was miraculously never empty. The fact of a still near by in the wild ravine might suggest a reason for its perennial flow. It was a good strong article of apple-brandy, and its effects were beginning to be distinctly visible.

Truly the ethereal woodland flower seemed strangely incongruous with these brutal and uncouth conditions of her life, as she stood at a little distance from this group, spinning at her wheel. Chevis felt a sudden sharp pain of pity for her when he glanced toward her; the next instant he had forgotten it in his 
interest in her work. It was altogether at variance with the ideas which he had hitherto entertained concerning that humble handicraft. There came across him a vague recollection from his city life that the peasant girls of art galleries and of the lyric stage were wont to sit at the wheel. "But perhaps they were spinning flax," he reflected. This spinning was a matter of walking back and forth with smooth, measured steps and graceful, undulatory motion; a matter, too, of much pretty gesticulation, - the thread in one hand, the other regulating the whirl of the wheel. He thought he had never seen attitudes so charming.

Jerry Shaw hastened to abdicate and offer one of the rushbottomed chairs with the eager hospitality characteristic of these mountaineers, - a hospitality that meets a stranger on the threshold of every hut, presses upon him, ungrudgingly, its best, and follows him on his departure with protestations of regret out to the rickety fence. Chevis was more or less known to all of the visitors, and after a little, under the sense of familiarity and the impetus of the apple-brandy, the talk flowed on as freely as before his entrance. It was wilder and more antagonistic to his principles and prejudices than anything he had hitherto heard among these people, and he looked on and listened, interested in this new development of a phase of life which he had thought he had sounded from its lowest note to the top of its compass. He was glad to remain; the scene had impressed his cultivated perceptions as an interior by Teniers might have done, and the vehemence and lawlessness of the conversation and the threats of violence had little reality for him; if he thought about the subject under discussion at all, it was with a reassuring conviction that before the plans could be carried out the already intoxicated mountaineers would be helplessly drunk. Nevertheless, he glanced ever and anon at the young girl, loath that she should hear it, lest its virulent, angry bitterness should startle her. She was evidently listening, too, but her fair face was as calm and untroubled as one of the pure white faces of those flower-stars of his early stay in the mountains. 
"Them Peels ought n't ter be let live!" exclaimed Elijah Burr, a gigantic fellow, arrayed in brown jeans, with the accompaniments of knife, powder-horn, etc., usual with the hunters of the range; his gun stood, with those of the other guests, against the wall in a corner of the room. "They ought n't ter be let live, an' I'd top all three of 'em fur the skin an' horns of a deer."

"That thar is a true word," assented Jerry Shaw. "They oughter be run down an' kilt,-all three o' them Peels."

Chevis could not forbear a question. Always on the alert to add to his stock of knowledge of men and minds, always analyzing his own inner life and the inner life of those about him, he said, turning to his intoxicated host, "Who are the Peels, Mr. Shaw,-if I may ask?"

"Who air the Peels?" repeated Jerry Shaw, making a point of seizing the question. "They air the meanest men in these hyar mountings. Ye might hunt from Copperhead Ridge ter Clinch River, an' the whole spread o' the valley, an' never hear tell o' no sech no 'count critters."

"They ought n't ter be let live!" again urged Elijah Burr. "No man ez treats his wife like that dad-burned scoundrel Ike Peel do oughter be let live. That thar woman is my sister an' Jerry Shaw's cousin,- -an' I shot him down in his own door year afore las'. I shot him ter kill; but somehow 'nother I war that shaky, $a^{\prime}$ the cussed gun hung fire a-fust, an' that thar pore wife o' his'n screamed an' hollered so, that I never done nuthin' arter all but lay him up for four month an' better for that thar pore critter ter nuss. He'll see a mighty differ nex' time I gits my chance. An' 't ain't fur off," he added threateningly.

"Wouldn't it be better to persuade her to leave him?" suggested Chavis pacifically, without, however, any wild idea of playing peacemaker between fire and tow.

Burr growled a fierce oath, and then was silent.

A slow fellow on the opposite side of the fireplace explained: "Thar's whar all the trouble kem from. She wouldn't leave him, fur all he treated her awful. She said ez how he were mighty good to her when he warn't drunk. So 'Lijah shot him."

This way of cutting the Gordian knot of domestic difficul- 
ties might prove efficacious but for the shakiness induced by the thrill of fraternal sentiment, the infusion of apple-brandy, the protest of the bone of contention, and the hanging fire of the treacherous gun. Elijah Burr could remember no other failure of aim for twenty years.

"He won't git shet of me that easy again!" Burr declared, with another pull at the flat tickler. "But ef it hed n't hev been fur what happened last week, I mought hev let him off fur awhile," he continued, evidently actuated by some curiously distorted sense of duty in the premises. "I oughter hev kilt him afore. But now the cussed critter is a gone coon. Dadburn the whole tribe!"

Chevis was desirous of knowing what had happened last week. He did not, however, feel justified in asking more questions. But apple-brandy is a potent tongue-loosener, and the unwonted communicativeness of the stolid and silent mountaineers attested its strength in this regard. Jerry Shaw, without inquiry, enlightened him.

"Ye see," he said, turning to Chevis, "'Lijah he thought ez how ef he could git that fool woman ter come to his house, he could shoot Ike fur his meanness 'thout botherin' of her, an' things would all git easy agin. Waal, he went thar one day when all them Peels, the whole lay-out, war gone down ter the Settlemint ter hear the rider preach, an' he jes' run away with two of the brats,-the littlest ones, ye onderstand,-a-thinkin' he mought tole her off from Ike that thar way. We hearn ez how the pore critter war nigh on ter distracted 'bout 'em, but Ike never let her come arter 'em. Leastways, she never kem. Las' week Ike kem fur 'em hisself,-him an' them two cussed brothers o' his'n. All 'Lijah's folks war out'n the way; him an' his boys war off a-huntin', an' his wife hed gone down ter the spring, a haffen mile an' better, a-washin' clothes; nobody war ter the house 'ceptin' them two chillen' o' Ike's. An' Ike an' his brothers jes' tuk the chillen away, an' set fire ter the house; an' time 'Lijah's wife got thar, 't war nuthin' but a pile o' ashes. So we've determinated ter go up yander ter Laurel Notch, twenty mile along the ridge of the mounting, ter-night, an' wipe out 
them Peels,-'kase they air a-goin' ter move away. That thar wife o' Ike's, what made all the trouble, hev fretted an' fretted at Ike till he hev determinated ter break up an' wagon across the range ter Kaintucky, whar his uncle lives in the hills thar. Ike hev gin his cornsent to go jes' ter pleasure her, 'kase she air mos' crazed ter git Ike away war 'Lijah can't kill him. Ike's brothers is a-goin', too. I hearn ez how they'll make a start at noon ter-morrer."

"They'll never start ter Kaintucky ter-morrer," said Burr grimly. "They'll git off, afore that, fur hell, stiddier Kaintucky. I hev been a-tryin' ter make out ter shoot that thar man ever sence that gal war married ter him, seven year ago,- - seven year an' better. But what with her a-foolin' round, an' a-talkin', an' a-goin' on like she war distracted-she run right 'twixt him an' the muzzle of my gun wunst, or I would hev hed him that time fur sure-an' somehow 'nother that critter makes me so shaky with her ways of goin' on that I feel like I hain't got good sense, an' can't git no good aim at nuthin'. Nex' time, though, thar'll be a differ. She ain't a-goin' ter Kaintucky along of him ter be beat fur nuthin' when he's drunk."

It was a pitiable picture presented to Chevis's open-eyed imagination,- - this woman standing for years between the two men she loved: holding back her brother from his vengeance of her wrongs by that subtle influence that shook his aim; and going into exile with her brute of a husband when that influence had waned and failed, and her wrongs were supplemented by deep and irreparable injuries to her brother. And the curious moral attitude of the man: the strong fraternal feeling that alternately nerved and weakened his revengeful hand.

"We air goin' thar 'bout two o'clock ternight," said Jerry Shaw, "and wipe out all three o' them Peels,-Ike an' his two brothers."

"They oughtn't ter be let live," reiterated Elijah Burr, moodily. Did he speak to his faintly stirring conscience, or to a woeful premonition of his sister's grief?

"They'll all three be stiff an' stark afore daybreak," resumed Jerry Shaw. "We air all kin ter 'Lijah, an' we air goin' ter holp 
him top off them Peels. Thar's ten of us an' three o' them, an' we won't hev no trouble 'bout it. An' we'll bring that pore critter, Ike's wife, an' her chillen hyar ter stay. She's welcome ter live along of us till 'Lijah kin fix some sort'n place fur her an' the little chillen. Thar won't be no trouble a-gittin rid of the men folks, ez thar is ten of us an' three o' them, an' we air goin' ter take 'em in the night."

There was a protest from an unexpected quarter. The whir of the spinning-wheel was abruptly silenced. "I don't see no sense," said Celia Shaw, her singing monotone vibrating in the sudden lull,--"I don't see no sense in shootin' folks down like they were nuthin' better nor bear, nor deer, nor suthin' wild. I don't see no sense in it. An' I never did see none."

There was an astonished pause.

"Shet up, Cely! Shet up!" exclaimed Jerry Shaw, in mingled anger and surprise. "Them folks ain't no better nor bear, nor sech. The hain't got no right ter live,- them Peels."

"No, that they hain't!" said Burr.

"They is powerful no' count critters, I know," replied the little woodland flower, the firelight bright in her opaline eyes and on the flakes of burnished gold gleaming in the dark masses of her hair. "They is always a-hangin' round the still an' a-gittin' drunk; but I don't see no sense in a-huntin' 'em down an' akillin' 'em off. 'Pears ter me like they air better nor the dumb ones. I don't see no sense in shootin' 'em."

"Shet up, Cely! Shet up!" reiterated Shaw.

Celia said no more. Reginald Chevis was pleased with this indication of her sensibility; the other women-her mother and grandmother-had heard the whole recital with the utmost indifference, as they sat by the fire monotonously carding cotton. She was beyond her station in sentiment, he thought. However, he was disposed to recant this favorable estimate of her higher nature when, twice afterward, she stopped her work, and, filling the bottle from the keg, pressed it upon her father, despite her unfavorable criticism of the hangers-on of stills. Nay, she insisted. "Drink some more," she said. "Ye hain't got half enough yit." Had the girl no pity for the already drunken crea- 
ture? She seemed systematically trying to make him even more helpless than he was.

He had fallen into a deep sleep before Chevis left the house, and the bottle was circulating among the other men with a rapidity that boded little harm to the unconscious Ike Peel and his brothers at Laurel Notch, twenty miles away. As Chevis mounted Strathspey he saw the horses of Jerry Shaw's friends standing partly within and partly without the blacksmith's shop. They would stand there all night, he thought. It was darker when he commenced the ascent of the mountain than he had anticipated. And what was this driving against his face,rain? No, it was snow. He had not started a moment too soon. But Strathspey, by reason of frequent travel, knew every foot of the way, and perhaps there would only be a flurry. And so he went on steadily up and up the wild, winding road among the great, bare, black trees and the grim heights and chasms. The snow fell fast, $\rightarrow$ so fast and so silently, before he was half-way to the summit he had lost the vague companionship of the sound of his horse's hoofs, now muffled in the thick carpet so suddenly flung upon the ground. Still the snow fell, and when he had reached the montain's brow the ground was deeply covered, and the whole aspect of the scene was strange. But though obscured by the fast-flying flakes, he knew that down in the bosom of the white valley there glittered still that changeless star.

"Still spinning, I suppose," he said to himself, as he looked toward it and thought of the interior of the log-cabin below. And then he turned into the tent to enjoy his cigar, his aesthetic reveries, and a bottle of wine.

But the wheel was no longer awhirl. Both music and the musician were gone. Toiling along the snow-filled mountain ways; struggling with the fierce gusts of wind as they buffeted and hindered her, and fluttered derisively among her thin, worn, old garments; shivering as the driving flakes came full into the pale, calm face, and fell in heavier and heavier wreaths upon the dappled calico sun-bonnet; threading her way through unfrequented woodland paths, that she might shorten 
the distance; now deftly on the verge of a precipice, whence a false step of those coarse, rough shoes would fling her into unimaginable abysses below; now on the sides of steep ravines, falling sometimes with the treacherous, sliding snow, but never faltering; tearing her hands on the shrubs and vines she clutched to help her forward, and bruised and bleeding, but still going on; trembling more than with the cold, but never turning back, when a sudden noise in the terrible loneliness of the sheeted woods suggested the close proximity of a wild beast, or perhaps, to her ignorant, superstitious mind, a supernatural presence,- thus she journeyed on her errand of deliverance.

Her fluttering breath came and went in quick gasps; her failing limbs wearily dragged through the deep drifts; the cruel winds untiringly lashed her; the snow soaked through the faded green cotton dress to the chilled white skin,-it seemed even to the dull blood coursing feebly through her freezing veins. But she had small thought for herself during those long, slow hours of endurance and painful effort. Her pale lips moved now and then with muttered speculations: how the time went by; whether they had discovered her absence at home; and whether the fleeter horsemen were even now ploughing their way through the longer, winding mountain road. Her only hope was to outstrip their speed. Her prayerthis untaught being! - she had no prayer, except perhaps her life, the life she was so ready to imperil. She had no high, cultivated sensibilities to sustain her. There was no instinct stirring within her that might have nerved her to save her father's, or her brother's, or a benefactor's life. She held the creatures that she would have died to warn in low estimation, and spoke of them with reprobation and contempt. She had known no religious training, holding up forever the sublimest ideal. The measureless mountain wilds were not more infinite to her than that great mystery. Perhaps, without any philosophy, she stood upon the basis of a common humanity.

When the silent horsemen, sobered by the chill night air and the cold snow, made their cautious approach to the little porch of Ike Peel's log-hut at Laurel Notch, there was a thrill of dis- 
mayed surprise among them to discover the door standing half open, the house empty of its scanty furniture and goods, its owners fled, and the very dogs disappeared; only, on the rough stones before the dying fire, Celia Shaw, falling asleep and waking by fitful starts.

"Jerry Shaw swore ez how he would hev shot that thar gal o' his'n,- that thar Cely," Hi Bates said to Chevis and Varney the next day, when he recounted the incident, "only he didn't think she hed her right mind; a-walkin' through this hyar deep snow full fifteen mile,-it's fifteen mile by the short cut ter Laurel Notch, - ter git Ike Peel's folks off 'fore 'Lijah an' her dad could come up an' settle Ike an' his brothers. Leastways, 'Lijah an' the $t^{\prime}$ others, fur Jerry hed got so drunk he could n't go; he war dead asleep till ter-day, when they kem back a-fotchin' the gal with 'em. That thar Cely Shaw never did look ter me like she hed good sense, no how. Always looked like she war queer an' teched in the head."

There was a furtive gleam of speculation on the dull face of the mountaineer when his two listeners broke into enthusiastic commendation of the girl's high heroism and courage. The man of ledgers swore that he had never heard of anything so fine, and that he himself would walk through fifteen miles of snow and midnight wilderness for the honor of shaking hands with her. There was that keen thrill about their hearts sometimes felt in crowded theatres, responsive to the cleverly simulated heroism of the boards; or in listening to a poet's mid-air song; or in looking upon some grand and ennobling phase of life translated on a great painter's canvas.

$\mathrm{Hi}$ Bates thought that perhaps they too were a little "teched in the head."

There had fallen upon Chevis a sense of deep humiliation. Celia Shaw had heard no more of the momentous conversation than he; a wide contrast was suggested. He began to have a glimmering perception that despite all his culture, his sensibility, his yearnings toward humanity, he was not so high a thing in the scale of being; that he had placed a false estimate upon himself. He had looked down on her with a mingled pity 
for her dense ignorance, her coarse surroundings, her low station, and a dilettante's delight in picturesque effects, and with no recognition of the moral splendors of that star in the valley. A realization, too, was upon him that fine feelings are of most avail as the motive power of fine deeds.

He and his friend went down together to the little log-cabin. There had been only jeers and taunts and reproaches for Celia Shaw from her own people. These she had expected, and she had stolidly borne them. But she listened to the fine speeches of the city-bred men with a vague wonderment on her flowerlike face,-whiter than ever to-day.

"It was a splendid-a noble thing to do," said Varney, warmly.

"I shall never forget it," said Chevis, "it will always be like a sermon to me."

There was something more that Reginald Chevis never forgot: the look on her face as he turned and left her forever; for he was on his way back to his former life, so far removed from her and all her ideas and imaginings. He pondered long upon that look in her inscrutable eyes,-was it suffering, some keen pang of despair?-as he rode down and down the valley, all unconscious of the heart-break he left behind him. He thought of it often afterward; he never penetrated its mystery.

He heard of her only once again. On the eve of a famous day, when visiting the outposts of a gallant corps, Reginald Chevis happened to recognize in one of the pickets the gawky mountaineer who had been his guide through those autumnal woods so far away. Hi Bates was afterward sought out and honored with an interview in the general's tent; for the accidental encounter had evoked many pleasant reminiscences in Chevis's mind, and among other questions he wished to ask was what had become of Jerry Shaw's daughter.

"She's dead,-long ago," answered Hi Bates. "She died afore the winter war over the year ez ye war a-huntin' thar. She never hed good sense ter my way o' thinkin', nohow, an' one night she run away, an' walked 'bout fifteen mile through a big snow-storm. Some say it settled on her chist. Anyhow, she jes' 
sorter fell away like afterward, an' never held up her head good no more. She always war a slim little critter, $\mathrm{an}^{\prime}$ looked like she war teched in the head."

There are many things that suffer unheeded in those mountains: the birds that freeze on the trees; the wounded deer that leaves its cruel kind to die alone; the despairing, flying fox with its pursuing train of savage dogs and men. And the jutting crag whence had shone the camp-fire she had so often watchedher star, set forever-looked far over the valley beneath, where in one of those sad little rural graveyards she had been laid so long ago.

But Reginald Chevis has never forgotten her. Whenever he sees the earliest star spring into the evening sky, he remembers the answering red gleam of that star in the valley. 


\section{The Star in the Valley}

1. What was the star in the valley which Reginald Chevis saw? Does the word star take on new meaning as the story progresses?

2. What is Jerry Shaw's relationship to the Peels? How does he feel about them? What plans does he make to upset Celia?

3. When Chevis learns of Celia Shaw's death, he feels a sense of humiliation. What has he come to realize about himself and about the girl?

4. Find the following words in the story. Write the sentence containing each work. Guess its meaning from the context. Look it up in the dictionary to see if your definition is correct. Write a sentence of your own using each word.
acquiescent
aperture
affinity
cogitation
ethereal
eminent
idyllic
inscrutable
opaline
prosaic 
JOHN FOX, JR. (1862-1919)

John Fox, Jr., born a Kentuckian, later lived in Big Stone Gap, Virginia. He graduated from Harvard University and became a writer and lecturer. After President Theodore Roosevelt attended one of his presentations, he invited Fox to the White House to read stories and sing mountain songs.

He is best known for his novels The Little Shepherd of Kingdom Come and The Trail of the Lonesome Pine. These novels and other works depict the lives of mountaineers in southwest Virginia, Tennessee, Kentucky, and West Virginia. While recounting the bitter feud between the Stetsons and the Lewallens in this excerpt from $A$ Cumberland Vendetta, he also reflects the universal theme of brotherly love.

\section{From A Cumberland Vendetta}

Just where young Stetson stood, the mountains racing along each bank of the Cumberland had sent out against each other, by mutual impulse, two great spurs. At the river's brink they stopped sheer, with crests uplifted, as though some hand at the last moment had hurled them apart, and had led the water through the breach to keep them at peace. To-day the crags look seamed by thwarted passion; and, sullen with firs, they made symbols of the human hate about the base of each. 
When the feud began, no one knew. Even the original cause was forgotten. Both families had come as friends from Virginia long ago, and had lived as enemies nearly half a century. There was hostility before the war, but, until then, little bloodshed. Through the hatred of change characteristic of the mountaineer the world over, the Lewallens were for the Union. The Stetsons owned a few slaves, and they fought for them. Peace found both still neighbors and worse foes. The war armed them, and brought back an ancestral contempt for human life; it left them a heritage of lawlessness that for mutual protection made necessary the very means used by their feudal forefathers; personal hatred supplanted its dead issues, and with them the war went on. The Stetsons had a good strain of Anglo-Saxon blood, and owned valley-lands; the Lewallens kept store, and made "moonshine"; so kindred and debtors and kindred and tenants were arrayed with one or the other leader, and gradually the retainers of both settled on one or the other side of the river. In time of hostility the Cumberland came to be the boundary between life and death for the dwellers on each shore. It was feudalism born again.

Above one of the spurs each family had its home: the Stetsons, under the seared face of Thunderstruck Knob; the Lewallens, just beneath the wooded rim of Wolf's Head. The eaves and chimney of each cabin were faintly visible from the porch of the other. The first light touched the house of the Stetsons; the last, the Lewallen cabin. So there were times when the one could not turn to the sunrise nor the other to the sunset but with a curse in his heart; for his eyes must fall on the home of his enemy.

For years there had been peace. The death of Rome Stetson's father from ambush, and the fight in the court-house square, had forced it. After that fight only four were left-old Jasper Lewallen, and young Jasper, the boy Rome, and his uncle, Rufe Stetson. Then Rufe fled to the West, and the Stetsons were helpless. For three years no word was heard of him, but the hatred burned in the heart of Rome's mother, and was traced deep in her grim old face while she patiently waited the 
day of retribution. It smouldered, too, in the hearts of the women of both clans who had lost husbands or sons or lovers; and the friends and kin of each had little to do with one another, and met and passed with watchful eyes. Indeed, it would take so little to turn peace to war that the wonder was that peace had lived so long. Now trouble was at hand. RufeStetson had come back at last, a few months since, and had quietly opened store at the county-seat, Hazlan-a little town five miles up the river, where Troubled Fork runs seething into the Cumberland-a point of neutrality for the factions, and consequently a battleground. Old Jasper's store was at the other end of the town, and the old man had never been known to brook competition. He had driven three men from Hazlan during the last term of peace for this offence, and everybody knew that the fourth must leave or fight. Already Rufe Stetson had been warned not to appear outside his door after dusk. Once or twice his wife had seen skulking shadows under the trees across the road, and a tremor of anticipation ran along both banks of the Cumberland....

All were smoking and silent. Several spoke from the shadows as Rome stepped on the porch, and Rufe Stetson faced him a moment in the doorway, and laughed. "Seem kinder s'prised?" he said, with a searching look. "Wasn't lookin' for me? I reckon I'll s' prise sev'ral ef I hev goodluck."

The subtlety of this sent a chuckle of appreciation through the porch, but Rome passed in without answer.

Isom lay on his bed within the circle of light, and his face in the brilliant glow was white, and his eyes shone feverishly. "Rome," he said, excitedly, "Uncle Rufe's hyeh, 'n' they laywayed him, ' $n$ ' - " He paused abruptly. His mother came in, and at her call the mountaineers trooped through the covered porch, and sat down to supper in the kitchen. They ate hastily and in silence, the mother attending their wants, and Rome helping her. The meal finished, they drew their chairs 
about the fire. Pipes were lighted, and Rufe Stetson rose and closed the door.

"Thar's no use harryin' the boy," he said; "I reckon he'll be too puny to take a hand."

The mother stopped clearing the table, and sat on the rock hearth close to the fire, her withered lips shut tight about a lighted pipe, and her sunken eyes glowing like the coal of fire in its black bowl. Now and then she would stretch her knotted hands nervously into the flames or knit them about her knees, looking closely at the heavy faces about her, which had lightened a little with expectancy. Rufe Stetson stood before the blaze, his hands clasped behind him, and his huge figure bent in reflection. At intervals he would look with half-shut eyes at Rome, who sat with troubled face outside the firelight. Across the knees of Steve Marcum, the best marksman in the mountains, lay the barrel of a new Winchester. Old Sam Day, Rufe's father-in-law and counsellor to the Stetsons for a score of years, sat as if asleep on the opposite side of the fireplace from the old mother, with his big square head pressed down between his misshapen shoulders.

"The time hev come, Rome." Rufe spoke between the puffs of his pipe, and Rome's heart quickened, for every eye was upon him. "Thar's goin' to be trouble now. I hear as how young Jasper hev been talkin' purty tall about ye-'lowin' as how ye air afeard o' him."

Rome felt his mother's burning look. He did not turn towards her nor Rufe, but his face grew sullen, and his voice was low and harsh. "I reckon he'll find out about that when the time comes," he said, quietly-too quietly, for the old mother stirred uneasily, and significant glances went from eye to eye. Rufe did not look up from the floor. He had been told about Rome's peculiar conduct, and, while the reason for it was beyond guessing, he knew the temper of the boy and how to kindle it. He had thrust a thorn in a tender spot, and he let it rankle. How sorely it did rankle he little knew. The voice of the woman across the river was still in Rome's ears. Nothing cuts the mountaineer to the quick like the name of coward. It 
stung him like the lash of an oxwhip then; it smarted all the way across the river and up the mountain. Young Jasper had been charging him broadcast with cowardice, and Jasper's people no doubt believed it. Perhaps his own did-his uncle, his mother. The bare chance of such a humiliation set up an inward rage. He wondered how he could ever have been such a fool as to think of peace. The woman's gossip had swept kindly impulses from his heart with a fresh tide of bitterness, and, helpless now against its current, he sullenly gave way, and let his passions loose to drift with it.

"Whar d' ye git the guns, Rufe?" Steve was testing the action of the Winchester with a kindling look, as the click of the locks struck softly through the silence.

"Jackson; 'way up in Breathitt, at the end of the new road."

"No wonder $y^{\prime} u^{\prime}$ ve been gone so long."

"I had to wait thar fer the guns, ' $n$ ' I had to travel atter dark comin' back, ' $n$ ' lay out' $n$ the bresh by day. Hit's full eighty mile up thar."

"Air ye shore nobody seed ye?"

The question was from a Marcum, who had come in late, and several laughed. Rufe threw back his dusty coat, which was ripped through the lapel by a bullet.

"They seed me well 'nough fer that," he said, grimly, and then he looked towards Rome, who thought of old Jasper, and gave back a gleam of fierce sympathy. There were several nods of approval along with the laugh that followed. It was a surprise-so little consideration of an escape so narrow-from Rufe; for, as old Gabe said, Rufe was big and good-natured, and was not thought fit for leadership. But there was a change in him when he came back from the West. He was quieter; he laughed less. No one spoke of the difference; it was too vague; but every one felt it, and it had an effect. His flight had made many uneasy, but his return, for that reason, brought a stancher fealty from these; and this was evident now. All eyes were upon him, and all tongues, even old Sam's waited now for his to speak.

"Whut we've got to do, we've got to do mighty quick," he 
began, at last. "Things air changin'. I seed it over thar in Breathitt. The soldiers ' $n$ ' that scar-faced Jellico preacher hev broke up the fightin' over thar, ' $n$ ' if we don't watch out, they'll be a-doin' it hyeh, when we start our leetle frolic. We hain't got no time to fool. Old Jas knows this as well as me, ' $n$ ' thar's goin' to be mighty leetle chance for 'em to layway ' $n$ ' pick us off from the bresh. Thar's goin' to be fa'r fightin' fer once, thank the Lord. They bushwhacked us durin' the war, ' $n$ ' they've laywayed us ' $n$ ' shot us to pieces ever sence; but now, of God A'mighty's willin', the thing's a-goin' to be settled one way or t'other at last, I reckon."

He stopped a moment to think. The men's breathing could be heard, so quiet was the room, and Rufe went on telling in detail, slowly, as if to himself, the wrongs the Lewallens had done his people. When he came to old Jasper his voice was low, and his manner was quieter than ever.

"Now old Jas have got to the p'int whar he says as how nobody in the county kin undersell him ' $n$ ' stay hyeh. Old Jas druv Bond Vickers out'n the mount'ins fer tryin' hit. He druv Jess Hale away; ' $n$ ' them two air our kin."

The big mountaineer turned then, and knocked the ashes from his pipe. His eyes grew a little brighter, and his nostrils spread, but with a sweep of his arm he added, still quietly:

"Y' all know whut he's done."

The gesture lighted memories of personal wrongs in every breast; he had tossed a firebrand among fagots, and an angry light began to burn from the eyes that watched him.

"Ye know, too, that he thinks he has played the same game with me; but ye don't know, I reckon, that he had ole Jim Stover ' $n$ ' that mis'able Eli Crump a-hidin' in the bushes to shoot me"-again he grasped the torn lapel; "that a body warned me to git away from Hazlan; ' $n$ ' the night I left home they come thar to kill me, ' $n$ ' s'arched the house, ' $n$ ' skeered Mollie ' $n$ 'the leetle gal 'most to death."

The mountaineer's self-control was lost suddenly in a furious oath. The men did know, but in fresh anger they leaned forward in their chairs, and twisted about with smothered cur- 
ses. The old woman had stopped smoking, and was rocking her body to and fro. Her lips were drawn in upon her toothless gums, and her pipe was clinched against her sunken breast. The head of the old mountaineer was lifted, and his eyes were open and shining fiercely.

"I hear as how he says I'm gone fer good. Well, I have been kinder easy-goin', hatin' to fight, but sence the day I seed Rome's dad thar dead in his blood, I hev had jes one thing I wanted to do. Thar wasn't no use stayin' hyeh; I seed that. Rome thar was too leetle, and they was too many fer me. I knowed it was easier to git a new start out West, ' $n$ ' when I come back to the mount'ins, hit was to do jes-whut-I'mgoing - to-do-now." He wheeled suddenly upon Rome, with one huge hand lifted. Under it the old woman's voice rose in a sudden wail:

"Yes; ' $n$ ' I want to see it done befoh I die. I hain't hyeh fer long, but I hain't goin' to leave as long as ole Jas is hyeh, ' $n$ ' I want ye all to know it. Ole Jas hev got to go fust. You hear me, Rome? I'm a-talkin' to you, boy; I'm a-talkin' to you. Hit's yo time now!"

The frenzied chant raised Rome from his chair. Rufe himself took up the spirit of it, and his voice was above all caution.

"Yes, Rome! They killed him, boy. They sneaked on him, ' $n$ ' shot him to pieces from the bushes. Yes; hit's yo' time now! Look hyeh, boys!" He reached above the fireplace and took down an old rifle- his brother's-which the old mother had suffered no one to touch. He held it before the fire, pointing to two crosses made near the flash-pan. "Thar's one fer ole Jim Lewallen! Thar's one fer ole Jas! He got Jim, but ole Jas got him, 'n' thar's his cross thar yit! Whar's yo' gun, Rome? Shame on ye, boy!"

The wild-eyed old woman was before him. She had divined Rufe's purpose, and was already at his side, with Rome's Winchester in one hand and a clasp-knife in the other. Every man was on his feet; the door was open, and the boy Isom was at the threshold, his eyes blazing from his white face. Rome had strode forward. 
"Yes, boy; now's the time, right hyeh before us all!"

The mother had the knife outstretched. Rome took it, and the scratch of the point on the hard steel went twice through the stillness-"one more fer the young un;" the voice was the old mother's - then twice again.

The moon was sinking when Rome stood in the door alone. The tramp of horses was growing fainter down the mountain. The trees were swaying in the wind below him, and he could just see the gray cliffs on the other shore. The morning seemed far away; it made him dizzy looking back to it through the tumult of the day. Somewhere in the haze was the vision of a girl's white face-white with distress for him. Her father and her brother he had sworn to kill. He had made a cross for each, and each cross was an oath. He closed the door; and then he gave way, and sat down with his head in both hands. The noises in the kitchen ceased. The fire died away, and the chill air gathered about him. When he rose, the restless eyes of the boy were upon him from the shadows.

It was court-day in Hazlan, but so early in the morning nothing was astir in the town that hinted of its life on such a day. But for the ring of a blacksmith's anvil on the quiet air, and the fact that nowhere was a church-spire visible, a stranger would have thought that the peace of Sabbath overlay a village of God-fearing people. A burly figure lounged in the porch of a rickety house, and yawned under swinging sign, the rude letters of which promised "private entertainment" for the traveller unlucky enough to pass that way. In the one long, narrow main street, closely flanked by log and framed houses, nothing else human was in sight. Out from this street, and in an empty square, stood the one brick building in the place, the courthouse, brick without, brick within; unfinished, unpencilled, unpainted; panes out of the windows, a shutter off here and there, or swinging drunkenly on one hinge; the door wide open, as though there was no privacy within - a poor structure, with the look of a good man gone shiftless, and fast going wrong. 
Soon two or three lank brown figures appeared from each direction on foot; then a horseman or two, and by-and-by mountaineers came in groups, on horse and on foot. In time the side alleys and the court-house square were filled with horses and mules, and even steers. The mountaineers crowded the narrow street: idling from side to side; squatting for a bargain on the wooden sidewalks; grouping on the porch of the rickety hotel, and on the court-house steps; loitering in and out of the one store in sight. Out in the street several stood about a horse, looking at his teeth, holding his eyes to the sun, punching his ribs, twisting his tail; while the phlegmatic owner sat astride the submissive beast, and spoke short answers to rare questions. Everybody talked politics, the crop failure, or the last fight at the seat of some private war; but nobody spoke of a Lewallen or a Stetson unless he knew his listener's heart, and said it in a whisper. For nobody knew when the powder would flash, or who had taken sides, or that a careless word might not array him with one or the other faction.

A motley throng it was-in brown or gray homespun, with trousers in cowhide boots, and slouched hats with brims curved according to temperament, but with striking figures in it: the patriarch with long, white hair, shorn even with the base of the neck, and bearded only at the throat-a justice of the peace, and the sage of his district; a little mountaineer with curling black hair and beard, and dark, fine features; a grizzled giant with a head rugged enough to have been carelessly chipped from stone; a bragging candidate claiming everybody's notice; a square-shouldered fellow surging through the crowd like a stranger; an open-faced, devil-maycare young gallant on fire with moonshine; a skulking figure with brutish mouth and shifting eyes. Indeed, every figure seemed distinct; for, living apart from his neighbor, and troubling the law but little in small matters of dispute, the mountaineer preserves independence, and keeps the edges of his individuality unworn. Apparently there was not a woman in town. Those that lived there kept housed, and the fact was significant. Still, it was close to noon, and yet not a Stetson or a 
Lewallen had been seen. The stores of Rufe and old Jasper were at the extremities of the town, and the crowd did not move those ways. It waited in the centre, and whetted impatience by sly trips in twos and threes to stables or side alleys for "mountain dew." Now and then the sheriff, a little man with a mighty voice, would appear on the court-house steps, and summon a witness to court, where a frightened judge gave instructions to a frightened jury. But few went, unless called; for the interest was outside: every man in the streets knew that a storm was nigh, and was waiting to see it burst.

Noon passed. A hoarse bell and a whining hound had announced dinner in the hotel. The guests were coming again into the streets. Eyes were brighter, faces a little more flushed, and the "moonshine" was passed more openly. Both ways the crowd watched closely. The quiet at each end of the street was ominous, and the delay could last but little longer. The lookers-on themselves were getting quarrelsome. The vent must come soon, or among them there would be trouble.

"Thar comes Jas Lewallen!" At last. A dozen voices spoke at once. A horseman had appeared far down the street from the Lewallen end. The clouds broke from about the sun, and a dozen men knew the horse that bore him; for the gray was prancing the street sidewise, and throwing the sunlight from his flanks. Nobody followed, and the crowd was puzzled. Young Jasper carried a Winchester across his saddle-bow, and, swaying with the action of his horse, came on.

"What air he about?"

"He's a plumb idgit."

"He mus' be crazy."

"He's drunk!"

The wonder ceased. Young Jasper was reeling. Two or three Stetsons slipped from the crowd, and there was a galloping of hoofs the other way. Another horseman appeared from the Lewallen end, riding hastily. The new-comer's errand was to call Jasper back. But the young dare-devil was close to the crowd, and was swinging a bottle over his head.

"Come back hyeh, Jas! Come hyeh!" The new-comer was 
shouting afar off while he galloped. Horses were being untethered from the side-alleys. Several more Lewallen riders came in sight. They could see the gray shining in the sunlight amid the crowd, and the man sent after him halted at a safedistance, gesticulating; and they, too, spurred forward.

"Hello boys!" young Jasper was calling out, as he swayed from side to side, the people everywhere giving him way.

"Fun to-day, by-! fun to-day! Who'll hev a drink! Hyeh's hell to the Stetsons, whar some of 'em'll be 'fore night!"

With a swagger he lifted the bottle to his lips, and, stopping short, let it fall untouched to the ground. He had straightened in his saddle, and was looking up the street. With a deep curse he threw the Winchester to his shoulder, fired, and before his yell died on his lips horse and rider were away like a shaft of light. The crowd melted like magic from the street. The Stetsons, chiefly on foot, did not return the fire, but halted up the street, as if parleying. Young Jasper joined his party, and they, too, stood still a moment, puzzled by the irresolution of the other side.

"Watch out! they' re gittin' round ye! Run for the courthouse, ye fools! - ye, run!" The voice came in a loud yell from somewhere down the street, and its warning was just in time.

A wreath of smoke came about a corner of the house far down the street, and young Jasper yelled, and dashed up a side-alley with his followers. A moment later judge, jury, witnesses, and sheriff were flying down the court-house steps at the point of Lewallen guns; the Lewallen horses, led by the gray, were snorting through the streets; their riders, barricaded in the forsaken court-house, were puffing a stream of fire and smoke from every window of court-room below and juryroom above.

The streets were a bedlam. The Stetsons were yelling with triumph. The Lewallens were divided, and Rufe placed three Stetsons with Winchesters on each side of the court-house, and kept them firing. Rome, pale and stern, hid his force between the square and the Lewallen store. He was none too quick. The rest were coming on, led by old Jasper. It was reckless, riding 
that way right into death; but the old man believed young Jasper's life at stake, and the men behind asked no questions when old Jasper led them. The horse's hoofs beat the dirt street like the crescendo of thunder. The fierce old man's hat was gone, and his mane-like hair was shaking in the wind. Louder-and still the Stetsons were quiet-quiet too long. The wily old man saw the trap, and, with a yell, whirled the column up an alley, each man flattening over his saddle. From every window, from behind every corner and tree, smoke belched from the mouth of a Winchester. Two horses went down; one screamed; the other struggled to his feet, and limped away with an empty saddle. One of the fallen men sprang into safety behind a house, and one lay still, with his arms stretched out and his face in the dust.

From behind the barn, house, and fence the Lewallens gave back a scattering fire; but the Stetsons crept closer, and were plainly in greater numbers. Old Jasper was being surrounded, and he mounted again, and all, followed by a chorus of bullets and triumphant yells, fled for a wooded slope in the rear of the court-house. A dozen Lewallens were prisoners, and must give up or starve. There was savage joy in the Stetson crowd, and many-footed rumor went all ways that night.

Despite sickness and Rome's strict order, Isom had ridden down to the mill. Standing in the doorway, he and old Gabe saw up the river, where the water broke into the foam over the ford, a riderless gray horse plunging across. Later it neighed at a gate under Wolf's Head, and Martha Lewallen ran out to meet it. Across under Thunderstruck Knob that night the old Stetson mother listened to Isom's story of the fight with ghastly joy in her death-marked face.

All night the court-house was guarded and on guard. At one corner of the square Rufe Stetson, with a few men, sat on watch in old Sam Day's cabin-the fortress of the town, built for such a purpose, and used for it many times before. The prisoners, too, were alert, and no Stetson ventured into the open square, for the moon was high; an exposure anywhere 
was noted instantly by the whistle of a rifle-ball, and the mountaineer takes few risks except under stress of drink or passion. Rome Stetson had placed pickets about the town wherever surprise was possible. All night he patrolled the streets to keep his men in such readiness as he could for the attack that the Lewallens would surely make to rescue their living friends and to avenge the dead ones.

But the triumph was too great and unexpected. Two Braytons were dead; several more were prisoners with young Jasper in the court-house; and drinking began.

As the night deepened without attack, the Stetsons drank more, and grew reckless. A dance was started. Music and "moonshine" were given to every man who bore a Winchester. The night was broken with drunken yells, the random discharge of firearms, and the monotone of heavy feet. The two leaders were helpless, the inaction of the Lewallens puzzled them. Chafed with anxiety, they kept their eyes on the courthouse or on the thicket of gloom where their enemies lay. But the woods were as quiet as the pall of shadows over them. Once Rome, making his rounds, saw a figure crawling through a field of corn. It looked like Crump's, but before he could fire the man rolled like a ball down the bushy bank to the river. An instant later some object went swiftly past a side-street-somebody on horseback. A picket fired an alarm. The horse kept on, and Rome threw his rifle on a patch of moonlight. When the object flashed through, his finger was numbed at the trigger. In the moonlight the horse looked gray, and the rider seated sidewise. A bullet from the court-house clipped his hatbrim as he ran recklessly across the street to where Steve Marcum stood in the dark behind old Sam's cabin.

"Jim Hale 'll git him as he goes up the road," said Steve, calmly-and then with hot impatience, "Why the hell don't he shoot?"

Rome started forward in the moonlight, and Steve caught his arm. Two bullets hissed from the court-house, and he fell back.

A shot sounded from the bushes far away from the road. 
The horse kept on, and splashed into Troubled Fork, and Steve swore bitterly.

"Hit ain't Jim. Hit's that mis'able Bud Vickers; he's been astandin' guard out' $n$ the bushes 'stid o' the road. That was a spy, I tell ye, 'n' the coward let him in and let him out. They'll know now we're all drunk! Whut's the matter?"

Rome's mouth was half open. He looked white and sick, and Steve thought he had been hit, but he took off his hat. "Purty close!" he said, with a laugh, pointing at the bullet-hole through the brim.

Steve, unsuspicious, went on: "Hit was a spy, I tell ye. Bud was afeard to stan' in the road, ' $n$ ' I'm goin' out thar ' $n$ ' twist his damned neck. We've got 'em, Rome! I tell ye, we've got 'em! Ef we kin git through this night, and git the boys sober in the morning, we've got 'em shore!"

The night did pass in safety, darkness wore away without attack, and morning broke on the town in its drunken stupor. Then the curious silence of the Lewallens was explained. The rumor came that old Jasper was dead, and it went broadcast. Later, friends coming to the edge of the town for the bodies of the dead Lewallens confirmed it. A random ball had passed through old Lewallen's body in the wild flight for the woods. During the night he had spent his last breath in a curse against the man that fired it.

Then each Stetson, waked from his drunken sleep, drank again when he heard of the death. The day bade fair to be like the night, and again the anxiety of the leaders was edged with fear. Old Jasper dead and young Jasper a prisoner, the chance was near to end the feud. There would be no Lewallen left to lead their enemies. But, again, they were well-nigh helpless. Already they had barely enough men to guard their prisoners. Of the Marcums, Steve alone was able to handle a Winchester. Outside the sounds of the carousal were in the air and growing louder. In a little while, if the Lewallens but knew it, escape would be easy and the Stetsons could be driven from the town.

"Oh, they know it," said Steve. "They'll be a-whoopin' 
down out $o^{\prime}$ them woods purty soon, ' $n$ ' we're goin' to ketch hell. I'd like to know mighty well who that spy was last night. That cussed Bud Vickers says it was a ha'nt, on a white hoss, with long hair flyin' in the wind, ' $n$ ' that he shot plumb through it. I jus' wish I'd a had a chance at it."

Still, noon came again without trouble, and the imprisoned Lewallens had been twenty-four hours without food. Their ammunition was getting scarce. The firing was less frequent, but the watch was as close as ever. Twice a Winchester had sounded a signal of distress. All knew that a response must come soon; and come it did. A picket, watching the river road, saw young Jasper's horse coming along the dark bushes far up the river, and brought the news to the group standing behind old Sam's cabin. The gray galloped into sight, and, skirting the woods, came straight for the town-with a woman on his back. The stirrup of a man's saddle dangled on one side, and the woman's bonnet had fallen from her head. Some one challenged her.

"Stop, I tell ye! Don't ye go near that court-house! Stop, I tell ye! I'll shoot! Stop!"

Rome ran from the cabin with a revolver in each hand. A drunken mountaineer was raising a Winchester to his shoulder. Springing from the back of the gray at the courthouse steps was Martha Lewallen.

"I'll kill the fust man that lifts his finger to hurt the gal," Rome said, knocking the drunken man's gun in the air. "We hain't fightin' women!"

It was too late to oppose her, and the crowd stood helplessly watching. No one dared approach, and, shielding with her body the space of the opening door, she threw the sack of food within. Then she stood a moment talking and, turning, climbed to her saddle. The gray was spotted with foam, and showed the red of his nostrils with every breath as, with face flushed and eyes straight before her, she rode slowly towards the crowd. What she was about! Rome stood rigid, his forgotten pistols hanging at each side; the mouth of the drunken mountaineer was open with stupid wonder; the rest fell apart 
as she came around the corner of the cabin and, through the space given, rode slowly, her skirt almost brushing Rome, looking neither to the right nor to the left; and when she had gone quite through them all, she wheeled and rode, still slowly, through the open fields towards the woods which sheltered the Lewallens, while the crowd stood in bewildered silence looking after her. Yells of laughter came from the old courthouse. Some of the Stetsons laughed, too; some swore, a few grumbled; but there was not one who was not stirred by the superb daring of the girl, though she had used it only to show her contempt.

"Rome, you're a fool; though, fer a fac', we can't shoot a woman; ' $n$ ' anyways I ruther shoot her than the hoss. But lemme tell ye, thar was more' $n$ than sump' $n$ to eat in that bag! They air up to some dodge."

RufeStetson had watched the incident through a port-hole of the cabin, and his tone was at once jesting and anxious.

"That grub won't last more'n one day, I reckon," said the drunken mountaineer. "We'll watch out fer the gal nex' time. We're boun' to git 'em one time or $t^{\prime}$ other."

"She rid through us to find out how many of us wasn't dead drunk," said Steve Marcum, still watching the girl as she rode on towards the woods; "'n' I'm a-thinkin' they'll be down on us purty soon now, ' $n$ ' I reckon we'll have to run fer it. Look thar, boys!"

The girl had stopped at the edge of the woods; facing the town, she waved her bonnet high above her head.

"Well, whut in the-" he said, with slow emphasis, and then he leaped from the door with a yell. The bonnet was a signal to the beleaguered Lewallens. The rear door of the court-house had been quietly opened, and the prisoners were out in a body and scrambling over the fence before the pickets could give an alarm. The sudden yells, the crack of Winchesters, startled even the revellers; and all who could, headed by Rome and Steve Marcum, sprang into the square, and started in pursuit. But the Lewallens had got far ahead, and were running in zigzag lines to dodge the balls flying after them. Half-way to the 
woods was a gully of red clay, and into this the fleetest leaped, and turned instantly to cover their comrades. The Winchesters began to rattle from the woods, and bullets came like rain from everywhere.

"T-h-up! T-h-up! T-h-up!" there were three of them-the peculiar soft, dull messages of hot lead to living flesh. A Stetson went down; another stumbled; Rufe Stetson, climbing the fence, caught at his breast with an oath, and fell back. Rome and Steve dropped for safety to the ground. Every other Stetson turned in a panic, and every Lewallen in the gully leaped from it, and ran under the Lewallen fire for shelter in the woods. The escape was over.

"That was a purty neat trick," said Steve, wiping a red streak from his cheek. "Nex' time she tries that, she'll git herself into trouble."

At nightfall the wounded leader and the dead one were carried up the mountain, each to his own home; and there was mourning far into the night on one bank of the Cumberland, and, serious though Rufe Stetson's wound was, exultation on the other. But in it Rome could take but little part. There had been no fault to find with him in the fight. But a reaction had set in when he saw the girl flash in the moonlight past the sights of his Winchester, and her face that day had again loosed within him a flood of feeling that drove the lust for revenge from his veins. Even now, while he sat in his own cabin, his thoughts were across the river where Martha, broken at last, sat at her death vigils. He knew what her daring ride that day had cost her, with old Jasper dead out there in the woods; and as she passed him he had grown suddenly humbled, shamed. He grew heartsick now as he thought of it all; and the sight of his mother on her bed in the corner, close to death as she was, filled him with bitterness. There was no help for him. He was alone now, pitted against young Jasper alone. On one bed lay his uncle-nigh to death. There was a grim figure in the corner, the implacable spirit of hate and revenge. His rifle was against the wall. If there was any joy for him in old Jasper's death, it was that his hand had not caused it, and yet-God help him!- 
there was the other cross, the other oath.

The star and the crescent were swinging above Wolf's Head, and in the dark hour that breaks into dawn a cavalcade of Lewallens forded the Cumberland, and galloped along the Stetson shore. At the head rode young Jasper, and Crump the spy.

Swift changes had followed the court-house fight. In spite of the death of Rufe Stetson from his wound, and several other Stetsons from ambush, the Lewallens had lost ground. Old Jasper's store had fallen into the hands of the creditors-"furriners"-for debts, and it was said his homestead must follow. In a private war a leader must be more than leader. He must feed and often clothe his followers, and young Jasper had not the means to carry on the feud. The famine had made corn dear. He could feed neither man nor horse, and the hired feudsmen fell away, leaving the Lewallens and the Braytons and their close kin to battlealone. So Jasper avoided open combat and resorted to ambush and surprise; and, knowing in some way every move made by the Stetsons, with great daring and success. It was whispered, too, that he no longer cared who owned what he might want for himself. Several dark deeds were traced to him. In a little while he was a terror to good citizens, and finally old Gabe asked aid of the governor. Soldiers from the settlements were looked for any day, and both factions knew it. At the least this would delay the war, and young Jasper had got ready for a last fight which was close at hand.

Half a mile on the riders swerved into a wooded slope. There they hid their horses in the brush, and climbed the spur stealthily. The naked woods showed the cup-like shape of the mountains there-a basin from which radiated upward wooded ravines, edged with ribs of rock. In this basin the Stetsons were encamped. The smoke of a fire was visible in the dim morning light, and the Lewallens scattered to surround the camp. The effort was vain. A picket saw the creeping figures; his gun echoed a warning from rock to rock, and with 
yells the Lewallens ran forward. Rome sprang from sleep near the fire, bareheaded, rifle in hand, his body plain against a huge rock, and the bullets hissed and spat about him as he leaped this way and that, firing as he sprang, and shouting for his men. Steve Marcum alone answered. Some, startled from sleep, had fled in panic; some had run deeper into the woods for shelter. And bidding Steve save himself, Rome turned up the mountain, running from tree to tree, and dropped unhurt behind a fallen chestnut. Other Stetsons, too, had turned, and answering bullets began to whistle to the enemy. But they were widely separated and ignorant of one another's position, and the Lewallens drove them one by one to new hiding-places, scattering them more. To his right Rome saw Steve Marcum speed like a shadow up through a little open space, but he feared to move. Several Lewallens had recognized him, and were watching him alone. He could not even fire; at the least exposure there was a chorus of bullets about his ears. In a moment they began to come obliquely from each side; the Lewallens were getting around him. In a moment more death was sure there, and once again he darted up the mountain. The bullets sang after him like maddened bees. He felt one cut his hat and another sting his left arm, but he raced up, up, till the firing grew fainter as he climbed, and ceased an instant altogether. Then, still farther below, came a sudden crash of reports. Stetsons were pursuing the men who were after him, but he could not join them. The Lewallens were scattered everywhere between him and his own men, and a descent might lead him to the muzzle of an enemy's Winchester. So he climbed over a ledge of rock and lay there, peeping through a crevice between two bowlders, gaining his breath. The firing was far below him now, and was sharp. Evidently his pursuers were too busy defending themselves to think further of him, and he began to plan how he should get back to his friends. But he kept hidden, and, searching the cliffs below him for a sheltered descent, he saw something like a slouched hat just over a log, scarcely fifty feet below him. Presently the hat was lifted a few inches; a figure rose cautiously and climbed 
towards the ledge, shielding itself behind rock and tree. Very quietly Rome crawled back to the face of the cliff behind him, and crouched behind a rock with his cocked rifle across his knees. The man must climb over the ledge; there would be a bare, level floor of rock between them-the Lewallen would be at his mercy-and Rome, with straining ears, waited. There was a foot-fall on the other side of the ledge; a soft clink of metal against stone. The Lewallen was climbing slowly-slowly. Rome could hear his heavy breathing. A grimy hand slipped over the sharp comb of the ledge; another appeared, clinched about a Winchester-then the slouched hat, and under it the dark, crafty face of young Jasper. Rome sat like the stone before him, with a half-smile on his lips. Jasper peered about with the sly caution of a fox, and his face grew puzzled and chagrined as he looked at the cliffs above him.

"Stop thar!"

He was drawing himself over the ledge, and the low, stern voice startled him, as a knife might have done, thrust suddenly from the empty air at his breast. Rome rose upright against the cliff, with his resolute face against the stock of Winchester.

"Drap that gun!"

The order was given along Stetson's barrel, and the weapon was dropped, the steel ringing on the stone floor. Rome lowered his gun to the hollow of his arm, and the two young leaders faced each other for the first time in the life of either.

"Seem kinder s' prised to see me," said the Stetson, grimly. "Hev ye got a pistol?"

Young Jasper glared at him in helpless ferocity.

"Naw!"

"Knife?"

He drew a long-bladed penknife from his pocket, and tossed it at Rome's feet.

"Jes' move over thar, will ye?"

The Lewallen took his stand against the cliff, Rome picked up the fallen rifle, and leaned it against the ledge.

"Now, Jas Lewallen, thar's nobody left in this leetle trouble 'cept you'n' me, ' $n$ ' ef one of us was dead, I reckon t'other could 
live hyeh, ' $n$ ' thar' $d$ be peace in these mountains. I thought $o^{\prime}$ that when I had ye at the end $o^{\prime}$ ' this Winchester. I reckon you would 'a' shot me dead ef I had poked my head over a rock as keerless as you." That is just what he would have done, and Jasper did not answer. "I've swore to kill ye, too," added Rome, tapping his gun; "I've got a cross fer ye hyeh."

The Lewallen was no coward. Outcry or resistance was useless. The Stetson meant to taunt him, to make death more bitter; for Jasper expected death, and he sullenly waited for it against the cliff.

"You've been banterin' me a long time now, 'lowin' as how ye air the better man o' the two; ' $n$ ' I've got a notion o' givin' ye a chance to prove yer tall talk. Hit's not our way to kill a man in cold blood, ' $n$ ' I don't want to kill ye anyways ef I kin he'p it. Seem s'prised ag'in. Reckon ye don't believe me? I don't wonder when I think $o$ ' my own dad, ' $n$ ' all the meanness yo' folks have done mine; but l've got a good reason fer not killin' ye-ef I kin he'p it. Y'u don't know what it is, ' $n$ ' $y^{\prime} u^{\prime} l l$ never know; but I'll give ye a chance now fer yer life ef $y^{\prime} u^{\prime} l l s^{\prime}$ ar on a stack o' Bibles as high as that tree thar that $y^{\prime} u^{\prime}$ ll leave these mount'ins ef I whoops ye,'a nuver come back ag'in as long as you live. I'll leave, ef ye whoops me. Now, whut do ye say? Will ye sw'ar!"

"I reckon I will, seein' as I've got to," was the surly answer. But Jasper's face was dark with suspicion, and Rome studied it keenly. The Lewallens once had been men whose word was good, but he did not like Jasper's look.

"I reckon I'll trust ye," he said, at last, more through confidence in his own strength than faith in his enemy; for Jasper whipped would be as much at his mercy as he was now. So Rome threw off his coat, and began winding his homespun suspenders about his waist. Watching him closely, Jasper did the same.

The firing below had ceased. A flock of mountain vultures was sailing in great circles over the thick woods. Two eagles swept straight from the rim of the sun above Wolf's Head, beating over a turbulent sea of mist for the cliffs, scarcely fifty yards 
above the ledge, where a pine-tree grew between two rocks. At the instant of lighting, they wheeled away, each with a warning scream to the other. A figure lying flat behind the pine had frightened them, and now a face peeped to one side, flushed with eagerness over the coming fight. Both were ready now, and the Lewallen grew suddenly white as Rome turned again and reached down for the guns.

"I reckon I'll put 'em a lettle furder out o' the way," he said, kicking the knife over the cliff; and, standing on a stone, he thrust them into a crevice high above his head.

"Now, Jas, we'll fight this gredge out, as our grandads have done afore us."

Lewallen and Stetson were man to man at last. Suspicion was gone now, and a short, brutal laugh came from the cliff.

"I'll fight ye! Oh, by God, I'll fight ye!"

The ring of the voice struck an answering gleam from Rome's gray eyes, and the two sprang for each other. It was like the struggle of primeval men who had not yet learned even the use of clubs. For an instant both stood close, like two wild beasts crouched for a spring, and circling about to get at each other's throats, with mouths set, eyes watching eyes, and hands twitching nervously. Young Jasper leaped first, and the Stetson, wary of closing with him, shrank back. There were a few, quick, heavy blows, and the Lewallen was beaten away with blood at his lips. Then each knew the advantage of the other. The Stetson's reach was longer; the Lewallen was shorter and heavier, and again he closed in. Again Rome sent out his long arm. A turn of Jasper's head let the heavy fist pass over his shoulder. The force of the blow drove Rome forward; the two clinched, and Jasper's arms tightened about Stetson's waist. With a quick grasp for breath Rome loosed his hold, and, bending his enemy's head back with one hand, rained blow after blow in his face with the other. One terrible stroke on the jaw, and Jasper's arms were loosed; the two fell apart, the one stunned, the other breathless. One dazed moment only, and for a third time the Lewallen came on. Rome had been fighting a man; now he faced a demon. Jasper's brows stood out 
like bristles, and the eyes under them were red and fierce like a mad bull's. Again Rome's blows fell, but again the Lewallen reached him, and this time he got his face under the Stetson's chin, and the heavy fist fell upon the back of his head, and upon his neck, as upon wood and leather. Again Rome had to gasp for breath, and again the two were fiercely locked-their corded arms as tense as serpents. Around and around they whirled, straining, tripping, breaking the silence only with deep, quick breaths and the stamping of feet, Jasper firm on the rock, and Rome's agility saving him from being lifted in the air and tossed from the cliff. There was no pause for rest. It was a struggle to the end, and a quick one; and under the stress of excitement the figure at the pine-tree had risen to his kneesjumping even to his feet in plain view, when the short, strong arms of the Lewallen began at last to draw Rome closer still, and to bend him backward. The Stetson was giving way at last. The Lewallen's vindictive face grew blacker, and his white teeth showed between his snarling lips as he fastened one leg behind his enemy's, and, with chin against his shoulder, bent him slowly, slowly back. The two breathed in short, painful gasps; their swollen muscles trembled under the strain as with ague. Back - back - the Stetson was falling; he seemed almost down, when-the trick was an old one-whirling with the quickness of light, he fell heavily on his opponent, and caught him by the throat with both hands.

"Nough?" he asked, hoarsely. It was the first word uttered.

The only answer was a fierce struggle. Rome felt the Lewallen's teeth sinking in his arm, and his fingers tightened like twisting steel, till Jasper caught his breath as though strangling to death.

"Nough?" asked the hoarse voice again.

No answer; tighter clinched the fingers. The Lewallen shook his head feebly; his purple face paled suddenly as Rome loosed his hold, and his lips moved in a whisper.

"Nough!"

Rome rose dizzily to one knee. Jasper turned, gasping, and lay with his face to the rock. For a while both were quiet, Rome, 
panting with open mouth and white with exhaustion, looking down now and then at the Lewallen, whose face was turned away with shame.

The sun was blazing above Wolf's Head now, and the stillness about them lay unbroken on the woods below.

"I've whooped ye, Jas," Rome said, at last; "I whooped ye in a fa'r fight, 'n' I've got nothin' now to say 'bout yer tall talk, 'n' I reckon you hevn't nuther. Now, hit's understood, hain't it, that $y^{\prime} u^{\prime}$ ll leave these mount'ins?

"Y'u kin go West," he continued, as the Lewallen did not answer. "Uncle Rufe used to say thar's a good deal to do out thar, ' $n$ ' nobody axes questions. Thar's nobody left hyeh but you ' $n$ ' me, but these mount'ins was never big 'nough fer one Lewallen ' $n$ ' one Stetson, ' $n$ ' you've got to go. I reckon ye won't believe me, but I'm glad I didn't hev to kill ye. But you've promised to go, now, 'n' I'll take yer word fer it." He turned his face, and the Lewallen, knowing it from the sound of his voice, sprang to his feet.

\section{"Oh-!"}

A wild curse burst from Rome's lips, and both leaped for the guns. The Lewallen had the start of a few feet, and Rome, lamed in the fight, stumbled and fell. Before he could rise Jasper had whirled, with one of the Winchesters above his head and his face aflame with fury. Asking no mercy, Rome hid his fae with one arm and waited, stricken faint all at once, and numb. One report struck his ears, muffled, whip-like. A dull wonder came to him that the Lewallen could have missed at such close range, and he waited for another. Some one shouted-a shrill halloo. A loud laugh followed; a light seemed breaking before Rome's eyes, and he lifted his head. Jasper was on his face again, motionless; and Steve Marcum's tall figure was climbing over a bowlder towards him.

"That was the best fight I've seed in my time, by God," he said coolly, "' $n$ ', Rome, $y^{\prime} u$ air the biggest fool this side $o$ ' the settlements, I reckon. I had dead aim on him, ' $n$ ' I was jest athinkin' hit was a purty good thing fer you that ole long-nosed Jim Stover chased me up hyeh, when, damn me, ef that boy up 
thar didn't let his ole gun loose. I'd a-got Jas myself ef he hadn't been so all-fired quick $o^{\prime}$ trigger."

Up at the root of the pine-tree Isom stood motionless, with his long rifle in one hand and a little cloud of smoke breaking above his white face. When Rome looked up he started down without a word. Steve swung himself over the ledge.

"I heerd the shootin'," said the boy, "up thar at the cave, ' $n$ ' I couldn't stay thar. I knowed ye could whoop him, Rome, ' $n$ ' I seed Steve, too, but I was afeard-" Then he saw the body. His tongue stopped, his face shrivelled, and Steve, hanging with one hand to the ledge, watched him curiously.

"Rome," said the boy, in a quick whisper, "is he daid?"

"Come on!" said Steve, roughly. "They'll be up hyeh atter us in a minute. Leave Jas's gun thar, ' $n$ ' send that boy back home."

That day the troops came-young Blue Grass Kentuckians. That night, within the circle of their camp-fires, a last defiance was cast in the teeth of law and order. Flames rose within the old court-house, and before midnight the moonlight fell on four black walls. That night, too, the news of young Jasper's fate was carried to the death-bed of Rome's mother, and before day the old woman passed in peace. That day Stetsons and Lewallens disbanded. The Lewallens had no leader; the Stetsons, no enemies to fight. Some hid, some left the mountains, some gave themselves up for trial. Upon Rome Stetson the burden fell. Against him the law was set. A price was put on his, head, his house was burned-a last act of Lewallen hate-and Rome was homeless, the last of his race, and an outlaw. 
JOHN FOX, JR. 119

\section{A Cumberland Vendetta}

1. Compare the backgrounds, families, and occupations of the Stetsons and Lewallens.

2. What was the main reason that Rufe Stetson wanted vengeance upon the Lewallens? What had Rufe Stetson done that angered Jasper Lewallen?

3. Explain the symbolism of the cross as it is used in this selection.

4. Discuss the following quotation as it applies to this story: "Love is a passion which kindles honor into noble acts." 


\section{ANNE W. ARMSTRONG (1872-1958)}

Anne W. Armstrong was born in Michigan but moved to Knoxville, Tennessee, when she was a child. She was a successful businesswoman who published articles and two novels, The Seas of God (1915) and This Day and Time (1930). As an assistant manager for industrial relations at Eastman Kodak, she became the first woman to lecture at the Harvard School of Business.

Mrs. Armstrong retired to Sullivan County, Tennessee, in the 1920's where she lived until the building of South Holston Dam forced her to move. She died at the Barter Inn in Abingdon, Virginia. She knew William Faulkner and Sherwood Anderson and was a friend of Thomas Wolfe. In the manner of the realistic writer, Anne Armstrong presents a slice of life showing Ivy Ingolsby, a strong and independent woman from This Day and Time, talking with her neighbors about everyday life.

\section{From This Day and Time}

The river glittered and flashed in the morning sun. A light breeze blew through the open doors, bringing the fresh pungent fragrance of the pines to mingle with appetizing smells issuing more and more strongly from the lean-to. Ivy, bustling about, busy with a dozen things, kept exclaiming to herself: 
"Did ever a body see sech a pretty day?" She had had no word from Shirley. No doubt Mr. Pemberton was better... .

Almost before she knew it, the birthday party had grown to its present proportions. Besides Mrs. Philips, she had asked Bertha Jane Dillard. "Of course, Bertha Jane, she's dry. She don't never have much $o^{\prime}$ nothin' to say. But, pore little old thing, she don't never git to go nowheres sence her mammy's gone, her sech a sight o' work to do!" After Bertha Jane, it had occurred to her to ask Short, just back from the mines. Then Molly Diggs, happening along on the way to the store, she had asked Molly. And in the midst of her preparations on Saturday morning, who should appear but Luke, his teeth gleaming, the color coming and going in his bronzed cheeks, Luke holding up a pair of squirrels he had shot. Luke had said: "Ivy, I brung ye a mess o' squirrels fer to-morrow." And there had been nothing to do but ask him. Well, there would be plenty for everybody.

Molly was the first to arrive, in a dark-blue calico, sprigged with white.

Ivy herself, not wishing to outshine her guests, fearful also lest with so much cooking she might drop something on her, had resisted the temptation to wear her silk dress and had put on a plain green linen that Shirley had given her.

"Law, Molly, hain't hit the nicest!" she exclaimed delightedly at sight of the bright new tin cake-pan Molly had brought as a birthday remembrance for Old Mag.

Molly helped her move the table from the lean-to into the front of the cabin and to spread the white table-cloth that Shirley had given her. "I believe, Molly, hit belongs jest a leetle mite the fur way."

Molly leaned over, examining the table-cloth with her staring, red-rimmed eyes. "Why, laws a mercy, Ivy, them's roses a-runnin' along hit!" She ran her red bony hand over the satiny damask, picking up a corner of the cloth to smell of it.

"An' good as new, fer the world," Ivy said, flying back and forth to the step-stove, so that nothing should burn. "Hain't more 'an two or three broke places, an' them darned nice." She 
had gathered a cluster of wild lilies, arranging them in a glass fruit-jar. "I'ull have me a flower-pot fer the dinner-table, same as Shirley allays done." She placed the jar in the center of the table. "Hain't no flowers on earth prettier 'an these here leopard-spot lilies!"

Lifting the cover from a frying-pan, she pierced with her fork one piece after another of the frying ground-hog, while Molly sniffed pleasurably. "Whistle-pig, Molly! Parbiled hit first, same as I done the squirrels. Gid, he went plumb to the mountain fer hit. Law, Molly, hain't hit nice? Jest so tender! Falls to pieces ef you teches hit!"

Ivy began to cut corn from the cob now, standing at the shelf that ran along the outside of the little back porch. Molly, her mouth full of snuff, pared the potatoes, stopping from time to time to step to the edge of the porch and spit.

"Mis' Byrd's a-goin' to have another baby, hain't she?" Molly said, suddenly dropping her voice to a whisper and bringing her burning eyes close to Ivy's.

"Law, yes, an' hit 'ull be a girl this time, her a-stickin' out in front so fur. When hit's a boy, they carries'em all around more."

Molly resumed her paring, but soon started whispering again. "Ivy, had you heern about Pernie Botts? Pernie, she kilt her baby, a-stompin' on hit."

Ivy drew back and stared. "Forevermore!"

"Pernie were in the bed an' she felt the baby a-comin', so she jumped up an' down right hard on the floor. She busted hit's skull."

"The Lord have mercy!" Ivy screamed.

"Pernie, she mashed hit's face till you couldn't tell hit were nothin' human."

"Law, Molly, I hain't never heern nothin' to beat hit in all the days o' my life!"

"Well, Shell, he bigged Pernie, an' Shell, he denied her when Pernie 'lowed they orter marry."

"Don't make no difference-I don't see how no woman alivin' kin kill a little baby, hit hern, an' them so sweet!"

They were still pursuing the subject when a noise warned 
them that Enoch was returning. Ivy had sent him for extra chairs and dishes. He was coming down the path, a big basket in one hand, a bucket in the other, followed in single file by Adam and Simon Peter, each carrying a splint-bottom chair on top of his head, with Enoch's little dog bouncing in and out of the procession, barking and nipping at two half-grown hounds that had followed the Philips boys.

"Mis' Philips sent ye some sweet milk," Enoch announced breathlessly.

"A gallon ef hit's a drap!-Now, don't you boys nasty your clothes. Hit's a right smart spell afore dinner."

She was setting the table a few moments later when Enoch announced that Short Dillard and Bertha Jane were approaching.

Ivy ran to the gate. "Forevermore! Why, Short, you're awalkin' good, hain't ye?-Bertha Jane-" but she stopped short. It was the first time she had seen the girl since her mother's death in the early spring. "Law, honey, how are ye?"

"Well enough, I reckon," Bertha Jane murmured huskily. Her short ill-fitting dress hung on her loosely, its vivid pink intensifying the pallor of her small childish face. Smiling shyly, she held out a bunch of marigolds and zinnias mixed with some sprays of sweet fennel. "I didn't have nothin' else. Reckon hit 'ull do?"

"Law, honey, ye couldn't a brung nothin' on earth no nicer! Look, Molly, this here flower-pot Bertha Jane brung fer Mag's birthday."

Short, a heavy-set youth, whose broad amiable face was still bleached from his weeks in the hospital, and who was walking with a stick, limping heavily, now proffered the tin bucket he was carrying. His father had found a bee-tree and taken sixty pounds of honey from it.

"Land o' livin'-sixty pounds! Well, I thank ye terrible, Short, you an' your pap, both.-Now, Bertha Jane, you jest set here an' rest. No, there hain't a earthly thing fer ye to do; Molly's a-helpin' me, an' looks like you're kinder out o' breath.-What do you reckon ails ye, Bertha Jane?" 
Bertha Jane smiled faintly. "Hit's the tubercles, I reckon." "Do you reckon-? Are you a-spittin' blood?"

Bertha Jane nodded. "An' Mammy, she had 'em."

"Law, yes, hit were the tubercles kilt your mammy, I reckon. They're ketchin', folks says-law, me!'

Ivy rejoined Molly in the lean-to.

"Uncle Abel," Molly whispered, with a snicker, "he's bound to git ye-a-sendin' honey!"

Ivy held up a warning finger. "Don't ye name hit, Molly, afore Short an' Bertha Jane, him their daddy!"

All at once a furious barking and yelping was heard. A big bony mongrel belonging to Luke had dashed into the yard, starting a fight with the other dogs, as Luke himself appeared from one direction, and from another Gid was seen, coming down the ridge, twirling two chairs above his head, with Nova, a blaze of red, mincing along the road, a few steps behind him.

Ivy, Molly, and Bertha Jane had all run to the door.

"Hain't her dress pretty?" Bertha Jane murmured, gazing wistfully at Nova, almost at the gate now, carrying a vanity case, her red organdie dress standing out crisp and dazzling.

"Yourn is a heap prettier," Ivy whispered. "I never did like no red dress!"

"Good God A'mighty!" Gid shouted, imitating Andy Weaver's familiar sniffle, as he peeped over the heads in the doorway. "Pon my honor! Why, what in the world?" He set the chairs down inside the cabin with a loud clatter; then, striking an attitude, surveyed the already loaded table while the others stood around to admire his foolery.

"Ivy, are ye a-aimin' to give me an' Novy a infare as fine as this here?"

The word "infare" set everyone shrieking. Jokes were cracked and a rough and tumble frolic started, even Short, though handicapped by his artificial leg, to which he was not yet accustomed, entering into the boisterous fun.

In the midst of the hubbub someone reported that Old Mag and Mrs. Philips were coming. Yes, there they were! Old Mag, her bare head high in the hot noonday sun, stalking along a lit- 
tle in advance of Mrs. Phillips.

"Don't Mag look nice!" burst from Ivy, as the two women drew nearer, Old Mag in a new dress of lavender gingham, barred with white. Ivy took a china bowl decorated with roses from the chest of drawers, holding it up for the others to see. "Seems like a berry-bowl allays comes in handy."

She forced Mag into a chair.

"Well, I do know!" Mag panted, glancing at the festive table. "Ivy, ef you hain't the beatin'est woman!" She was smiling broadly, but in her embarassment took down her wisp of hair, holding the hairpins in her mouth, then coiled it up again.

Nova had brought a small silk handkerchief, her mother a red-bordered face-towel; and Luke drew forth a paper bag of stick candy from one pocket, two oranges from another. The berry-bowl, the cake-pan, Bertha Jane's bouquet-all the gifts were showered at once into Mag's capacious lap.

Old Mag took up one thing after another, handling the gifts tremblingly. She tried to speak. It was no use. Her head dropped to her breast.

"Ef she hain't a-blubberin'!" Mrs. Philips's keen black eyes were filled at once with amusement and a little concern. The others had backed away, but Mrs. Philips placed her hand on Mag's shoulder "Law, Mag, you must git your countenance! Ivy's done hit to please ye!"

Mag lifted her head. The tears were streaming down her furrowed, weather-beaten face. She raised her hand helplessly, the big-knuckled, seamed, and coarsened hand of one who has done much outdoor work, trying fumblingly to wipe her wet face with the back of it. "I hain't never done nothin' to deserve sech as this!"

"Law, Mag"-Ivy had found her voice--"there hain't no kinder person a-livin'! There hain't no free-hearteder-to what ye've got!"

Mag shook her head. "I hain't no good woman!" She looked around from one to the other, humbly, heartbrokenly. Her dull, cavernous eyes blinded with tears, she reached down, trying to pull up her skirt, weighted with the birthday gifts. 
In a flash Gid recovered himself. Picking up the small square of silk, Nova's gift, he forced it into his mother's big clumsy hand. "Here, use this, old lady, an' no more bawlin', without ye want me to lick hell outen ye!"

Old Mag burst out laughing, the others, in sudden relief, all joining in.

Luke insisted now that they should follow the usual custom. "Come, folks, we must put Mag under the table, so she won't stop a-growin'!" There was a wild scramble, Old Mag, by no means feeble, pushing them off, and everyone roaring with laughter. Finally Mag's gaunt frame was stretched out on the floor, Ivy jerking down the skirt of her dress, disarrayed in the tussle, and skrieking at the same time that the others should save her table, which was rocking back and forth, threatening to crash any instant.

"Well, you-all kin set down," Ivy announced at last. "I reckon the last one $o^{\prime}$ ye is starved to death."

Everyone continued, however, to stand around awkwardly. Mag and Mrs. Philips and Molly all sought the front porch to spit again. Nova opened the vanity case to dab her face once more.

"Mag, you set here," Ivy broke the hush that had fallen, indicating a chair at the top of the table, facing the front door, "an' Gid to the side o' ye. Mis' Philips, you set yander, opposite Mag. The balance kin set where they likes."

Mrs. Philips and Old Mag both stroked the white cloth. "Law, Ivy, hain't it nice!" Both of them, as Molly had done, picked up the corner of the cloth and smelled of it.

Fresh fun was created when Nova, showing her dimples, slipped into the chair on the other side of Gid from his mother. General joking was resumed now and dishes that were on the table began to be circulated.

Rosy with heat, dripping with perspiration, Ivy bustled back and forth to the lean-to, passing food that the table had no space to hold and urging her guests to help themselves liberally. "Law, I don't want nobody to be in no ways bashful!" 
She was conscious of a vague sense of relief. Here, among her own people, there was no strain for fear she might do or say the wrong thing, something that would betray her poor rough upbringing in Rocky Hollow.

And how proud she was! She saw the room, almost as though she stood outside of it, as a picture she would hold in her mind unforgettably-her two high tightly stuffed beds, like fat pincushions, shining out, each from its corner, in the freshly washed bed-spreads, the bunches of herbs hanging from the rafters, Uncle Jake's clock on the chimney-shelf, the table extending almost from door to door, beautiful in the white cloth Shirley had given her, with the jar of wild lilies, with the gay flowers Bertha Jane had brought, resplendent with brightcolored jellies and pickles - then, everyone in clean Sabbath attire, and vivid patches where Nova and Bertha Jane sat in their scarlet and pink dresses-a living picture that glowed softly in the tempered light, that threw off enchanting odors, odors of steaming food mingled with the slightly suffocating sweet of the lilies, with the aromatic scent of the fennel in Bertha Jane's bouquet.... Oh, if only Jim should step in now!

The big platter of string-beans and potatoes boiled with bacon soon needed replenishing. Mounds of soda-biscuits, toppling pyramids of corn-bread, dishes of fried corn and fried cabbage, fried squirrels, the fried whistle-pig, bowls of gravy, of stewed tomatoes, of raw onions-all melted away until Enoch and Adam and Simon Peter, who were stationed about the table, eyeing it hungrily as they waved their green branches to keep the flies away, began to look at each other in consternation. But still Ivy plied her guests with fresh food and drink. "Bertha Jane, have ye another glass o' sweet milk.-Law, Mag, your coffee's plumb cold-let me pour ye some hot.-Luke, ye hain't a-settin' back a'ready? Why, you hain't hardly began!Molly, try them spiced beets. They're fine, they hain't a mite stringy.-Law, Gid, you an' Novy is lovesick, I reckon-youall ain't eatin' a bite!-Mis' Philips, help yourself to the honey, an', Short, would ye pass the cheese?-Hain't none o' ye tasted the jelly-there's apple an' plum an' blackberry." 
The lean days of spring were over, almost forgotten. Now, in the day of plenty, folks could eat to repletion, gorge themselves joyfully.

"Ivy, everything's grand!" Mag helped herself for the third time to fried cabbage. "Lord a' mercy, I'm a-eatin' a sight-fer me!-I've had a right smart o' indigestion here lately, an' I don't kmow what on earth's a-causin' hit."

But although the whole meal was praised, nothing else called forth such enthusiasm as the whistle-pig. Everyone agreed that no other wild meat could compare with it, unless perhaps coon-everyone except Short Dillard. "Law, people, ef you wants somethin' good, hit's mush-rats! Hain't no eatin' on earth 'ull tech young mush-rats!"

"A heap o' folks thinks polecat is mighty good eatin'," Old Mag added to the discussion, "but phew! a polecat, hit allays tastes to me like hit smells."

The noise of eating at length began to subside, the clatter and click of dishes and cutlery grew gradually fainter. The river could be heard once again, a dull murmur. Everyone was sitting back to rest, before starting on the pies and cake, for which they had made their plates ready, when a warning "Hello!" told them that Doke Odum was descending from the road.

"In the name o' God, hain't you folks done eatin'? Why, the cows is a-comin' home!"

Doke's overalls-one patch laid upon another, innumerable shades of faded blue-for once were clean. He was freshly shaven and a pale bluish rim around the edge of his black bushy hair showed that it had been recently trimmed. "No, thank ye, Molly, jest keep your seat-I've had my dinner." Standing at the foot of the table, his battered hat in his hand, Doke's eyes roved over it with good-humored envy. The table was somewhat disordered now, the cloth splattered with gravy and spotted with coffee, but it was still abundantly supplied with tempting dishes, while the blackberry and apple pies and the coconut cake were only starting to be passed.

Molly finally prevailed upon Doke to take her chair, and soon he was completely at home. "Mis' Philips, retch me that 
spoon o' yourn, ef you're done with hit. Hain't no need to nasty up another.-Short, I heern the company give ye seventy-five dollars. By God, anybody where wants 'em kin have both o' my legs-fer that!"

"There's some of 'em said I orter git a right smart more," Short explained, after the laughter had died down, "but I couldn't find out nothin' fer certain. They made me sign some papers, an' I asked 'em to read the papers to me, so I could tell what I were a-signin'. But they said they never had no time. One of them fellers in the office, he said: 'You're a nice bird! Think we want to rob a pore miner?' That there's jest the way he spoke hit. There's the very words he used. Then I asked the doctor ef any more money were a-comin' to me, but, boys, he shet me up proper! Well, sir, there's the shortest-spoken man ever I seed-I don't bar none! Short as piecrust."

Bertha Jane leaned forward when her brother had finished, her small pallid face dyed crimson. "Short," she said, smiling shyly and clearing her throat, "ef he gits two hundred, he's agoin' to git us a parlor set."

"The Lord have mercy!"Old Mag and Ivy shouted in unison. "A parlor-set!"

By the time Ivy sat down she was too tired to eat. She lingered over her plate, resting, trying to swallow a few bites. The others were moving about, yawning, stretching themselves, belching unashamedly, patting their full stomachs.

Molly and Mrs. Philips at length started washing the dishes. Luke and Doke had taken up their stand in the shade of the corn-crib, where they could hail any passer-by, leaning against it, with Short seated on a bank near by, all three of them whittling lazily.

All at once, Ivy remembered the tooth-brush which she had placed conspicuously on top of the chest of drawers. One day, some weeks before, when she was complaining of toothache, a woman from town, spending the day at the Pemberton cottage, had recommended the use of a tooth-brush. Ivy had answered, a trifle resentfully: "Birch twigs, to chew 'em, is way yonder 
better to clean a body's teeth." But now she called out: "Don't you-all want to use my tooth-brush? A tooth-brush is way yonder better 'an birch twigs to clean a body's teeth."

She was showing the brush to Gid and Nova, who had come inside from the porch-"Hain't hit a nice un? I paid a quarter fer hit"-when Luke announced softly from the doorway, smiling and raising his eyebrows: "Ivy, there's a stranger come to see ye!"

A stranger! Suddenly Ivy felt weak and dizzy. Her heart seemed to be missing beats. She looked out the door, the others craning their necks. No, it was not Jim.

"What's his business?" she asked dully.

"I couldn't tell ye. He asked ef this were where Mistress Ivy Ingoldsby lived. But I reckon he's a-settin' out," Luke added, in his gentle drawling voice, a gleam of mischief in his soft dark eyes. "He's a-wearin' flowers in his hat."

Gid emitted a snort.

The stranger was standing against the paling fence, outside the gate. Turning as Ivy came towards him, he eyed her with unconcealed curiosity. A tall raw-boned man, he wore a newlooking suit of clothes and a broad-brimmed black hat with two or three short-stemmed zinnias thrust through the band.

"Is this Mistress Ivy Ingoldsby?" he inquired in a deep rumbling voice, looking Ivy boldly in the eye.

"Yes, sir."

"My name's Yancy I'm a widdy man, a grass-widdy man. I live yon side the mountain, in Shady Valley."

Ivy held the gate open. "Won't ye come in, sir?"

"I kin state my business with ye here." He eyed her again unhurryingly. "Ef ever I saw ye afore, I don't know hit-but I've heern tell o' ye."

"Ye say ye have?"

"Big Bill Byrd-me an' him worked togither, loggin'-Bill, he were allays a-braggin' on ye."

"Won't ye come in, sir, an' have ye a cheer?"

The man glanced towards the cabin suspiciously. "Hit's best to see ye to yourself.-I'm a-huntin' me a wife-Bill, he 
'lowed you was the workin'est woman ever he seen."

"I hain't no lazy-bones," Ivy admitted, with an embarrassed laugh.

"My woman, she died on me, hit were two years back. I got me another, but this here last un-well, she were a powerful hand to waste, an' I tell ye what's the truth, a woman kin throw out more by the window with a spoon 'an a man kin throw in at the door with a shovel."

"Law, yes."

"Looked like me an' her couldn't make it." He spat, waiting for some time before he resumed: "Me an' her's parted. Well," he said explosively after another long pause, "seems like I wasn't much satisfied with her nohow. I'lowed I 'ud git me a woman this time where hain't a-gittin' up in years. How old are ye, Ivy?" he asked abruptly.

"I were twenty-six last May."

He studied Ivy's neat, vigorous figure in the green linen dress appraisingly for a moment or so. "You're stout, hain't ye?"

"Law, I hain't in no ways weakly," Ivy laughed nervously.

"Bill Byrd, he said you was savin', an' kep everything nice."

"Law, I hain't no nasty woman!"

"Four o' my children is married, but I've got five little fellers, an' a man cain't do no good a-lookin' atter hisself an' young uns."

"Law, no." Ivy had dropped her eyes again.

"I hain't no hard man to fix fer, more' $n$ I wants biscuits fer my breakfast. There's fellers where's satisfied with nothin' on'y beans an' corn-bread. But I wants my wheat bread, me, of a mornin'."

"Yes, sir."

"I hain't no braggart, nobody cain't put no name o' braggart on me, but I've got me a good house."

"Law, I reckon," Ivy breathed, more and more embarrassed.

"I don't want no house so fine a man cain't spit in hit, but I've got me a good sound house, two rooms. I put me some new oak boards on the roof here lately an' hit don't hardly leak a 
drap." He spat again, deliberately. "I've got me a good gang o' chickens-I've got several, forty or fifty, I reckon, an' I've got two nice fat shotes where 'ull be plenty large to kill afore Thanksgivin'." The stranger looked around him. "Ivy, ye hain't got ary pig to your name, have ye?"

"Law, no, sir,-shotes is so expensive, to buy 'em, this day an time, an' I never did keep me no sow."

"I've got two cows, or did have. I sold one day afore yesterday, but I kep' the best un, her fresh, an' the milk jest a-pourin'."

Ivy caught a titter from the cabin.

The stranger came nearer, bringing his red hatchet-shaped face with its prominent nose close to hers. "I 'ull buy ye a dress, an' a new pair o' slippers."

Ivy drew back. "Thank ye, but I've got plenty clothes."

The stranger gave a short laugh. He looked at her with astonishment. "You say ye have-? Well, I reckon ye wouldn't mind to get a new outfit, nohow." He stood a long time now, looking down reflectively at the river, off at the mountains. "Well, Ivy, I thought I'ud come to see ye. I think you'd suit me, an' we orter marry."

"Law, mister," Ivy burst forth now, her cheeks flaming, "I've got a man-me an' him hain't never been divorced!"

The stranger nodded. "I know ye hain't got ye no divorce, Ivy." He drew out a thick roll of bills. "I come prepared to git ye one."

"Thank ye, an' I wouldn't doubt hit, sir, you 'ud make a good man fer some woman where's a-wantin' to marry, but I'm a-makin' hit by myself, a-makin' hit good, an' atter the man I had, the way he done me-law, I don't want no man on earth! But won't ye come in, sir, an' rest yourself? Won't ye have some dinner?"

The stranger put the roll of bills back into his pocket.

"We've done et, but you've come a fer piece, sir, an' I know I kin find yea bite o' somethin', ef hit hain't no more'an a snack."

"Well," the stranger said at last, thoughtfully, and looking off into the distance again, "well, I reckon there hain't but one thing fer me to do." He dropped his head, letting it hang for a 
moment or so, then threw it back with a jerk. "Well, good-day to ye. Ef you should change your mind, ef you should take a notion to write, my name's Jack Yancy, Shady Post Office. I think you 'ud suit me tol'able well. Well, good-day. I'ull be agoin' along. I 'ull be travelin' back over the mountain." He climbed the path to the road, pausing at the corn-crib to remove his hat and wipe his forehead. "Hit's a warm day, gentlemen, sort o' close like."

"That were old big-mouth Jack Yancy," Mag exclaimed, as soon as the stranger was out of ear-shot, "nobody but him; useter live somewhars over around Popular Tree, an' so ill nobody on earth cain't live with him."

"Jack Yancy," Doke nodded, "that's him! Kilt his woman, the first un, a-kickin' her in the belly when she were in the family way."

"Hesh your mouth, Doke!" Ivy said.

"'My name's Yancy,'" Gid started rumbling. "'I'm a widdy man, a grass-widdy man. Ivy, I think you 'ud suit me good. We orter marry."

Everyone was roaring with laughter by this time, and Ivy began to repeat what the stranger had said to her: "Them was the very words he said. That there's jest the way he spoke hit." 
134 Local Color and Realistic Tradition

\section{This Day and Time}

1. What do you learn about Ivy Ingoldsby and her friends as you read about the birthday party at Ivy's house?

2. Describe the custom which Ivy and the others perform at Old Mag's party.

3. Why does Jack Yancy come to Ivy's house and what does he offer her? Do you think she was tempted by this offer? Explain.

4. Jack Yancy makes a very straightforward proposal to Ivy. Is this the kind of proposal you would make or like to receive? Explain. 


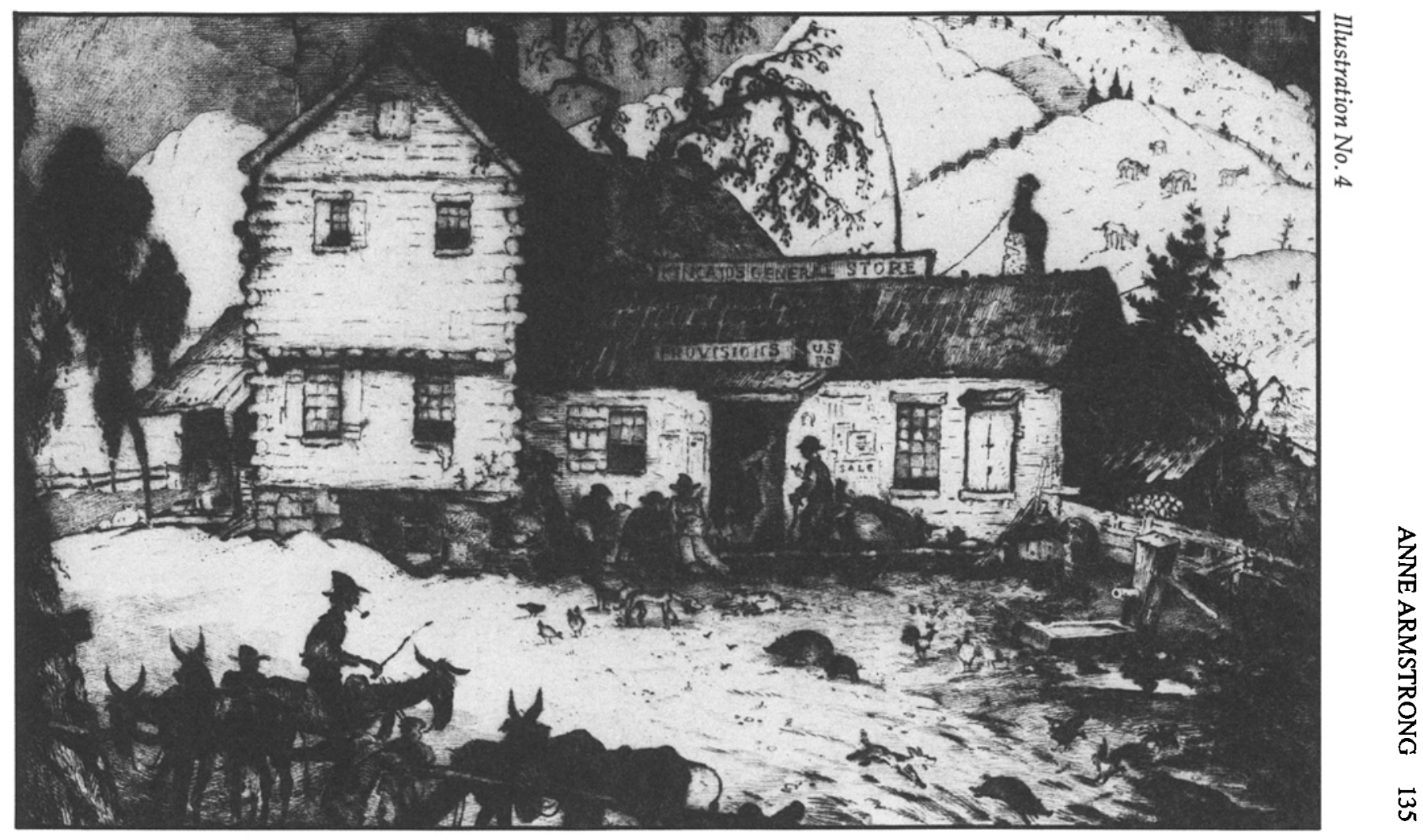




\section{MILDRED HAUN (1911-1966)}

A native of Hamblen County, Tennessee, Mildred Haun grew up in the Hoot Owl District of Cocke County. She lived there in the Smoky Mountains until she moved to Franklin, Tennessee, where she attended high school and prepared for college. At Vanderbilt, she studied with the famous Southern poets John Crowe Ransom and Donald Davidson. After completing her M.A. at Vanderbilt, she studied for a year at the University of Iowa.

For subject matter, Haun always returned to what she knew best-the people in Cocke County. Her stories focus on the hardship and cruelty of life in her region. Her collection of stories The Hawk's Done Gone was published in 1941. It is the only book she published in her lifetime. These searing stories arise from a dark and fascinating world where superstition and the supernatural are dominant forces.

In the title story from The Hawk's Done Gone the narrator stands helpless while her husband and son yield her priceless heirlooms to an antique collector. To her, each piece represents her life. As she sees these reminders carried away, she is powerless. We see her slowly losing her grip on life and reality, and giving in to despair. 


\section{From The Hawk's Done Gone}

I wonder why Ad and Linus never tried to sell me off to them hunters for old things. I would be a sight for somebody to look at. Big and motley and rough-looking. Old and still strong for my age. I miss the things they have sold. These newfangled things are weak. They make me feel weak too. But I ought not to be setting here nursing this old Bible. I ought to get out and pick some sallet for supper.

The Bible is about the only thing I have left, though. I thought I couldn't thole it when Ad and Linus first started selling off my stuff. I hate them folks that come around hunting for things to put in the Smoky Mountain Museum. And I nigh hate Linus for letting them have my things. Linus is Ad's youngest boy by his first old woman and he has been spoiled rotten. Ad is the one that spoiled him too. Ad has turned everything over to him and let him run it to suit hisself-my own stuff too.

William Wayne was the only one of them antique hunters that was decent. Him and that painted-up woman he called Miss Robinson come together. I recollect that first day when they come. I was bent over the tub washing. Miss Robinson, she strutted up like she thought she was something on a stick, all dyked out in a purple silkdress and spike-heeled shoes. The first thing she did was to commence complaining about having to walk through the mud.

Miss Robinson's old hawk eyes seed everything I had. She got around Linus and got nigh everything I wanted to keep. She picked out the things she wanted. Looked at both of my corded bedsteads. One of them wasn't in very good shape, she said, and she didn't know whether she would take it or not. I felt like giving her a piece of my mind. And I did flare up a little. I looked at her straight and I said, "Who said anything about you taking either one of them? Them is the first bedsteads my pa ever made-made them for him and Ma to start housekeeping on. I was born in this one hyear and all my youngons were born in it." 
I recollect the way I said it to her. I recollect the way William Wayne looked-almost like the soldier boy looked at me that day - that first day. William Wayne had brown eyes-big brown eyes that smiled as much as his mouth did. He put me in mind of the soldier, smiling all the time and talking so gentle. But Charles would be old by now. Old enough to be dead. He was older than me back then. I was just fifteen year old and he was a full-grown man. At least he was old enough to be out fighting the Yankees. At first I thought William Wayne might be Charles's boy maybe. But then I knowed Charles wouldn't ever have any other boy. William Wayne had pity for me and he hated to take my bedsteads away.

It didn't matter who had pity, though, for Linus and Miss Robinson made the bargain. The very next day Miss Robinson would send a wagon up here with two brought-on bedsteads, pretty ones, she said, to swop for my two wild-cherry ones.

And nigh all my quilts too. That huzzy said she would take all the pretty ones. Said some of them were mighty dirty but she could have them cleaned. My "Harp of Columbia." Of course, Miss Robinson's hawk eyes got set on it the very first thing. The one I was piecing on when Charles come.

I was setting in here in the big house piecing on it when I heard the soldiers walk up into the yard-setting here in the old hickory rocking chair with Ma's red-and-tan checked homespun shawl around my shoulders. I kept it in my hand when I started to get the water for them. I held it all the time while Charles went to the spring. He looked at the quilt when he come back.

"What's that you are making there?" he asked. He took hold of it and fingered it like it was a piece of gold. "I never could handle them little squares and three-cornered pieces with my big fingers," he said. And his hands were big. But I knowed right then I wasn't afeard of Charles.

I could tell from the way he kept looking at me he thought I was pretty too. He didn't tell me till all the other soldiers went over in the horse lot to catch up Old Kate. He didn't come right out plain and tell me then. "I'll bet your name is Edith-or 
Mary one."

"Huh uh-Mary's just part of it."

"Mine is Charles-Charles Williams. What is the rest of yours?"

"Hit's Dorthula-Mary Dorthula White."

"It's pretty too." In that deep voice. He kept feeling of the quilt. And looking at me. "Does that little red blanket on your shoulders keep you warm?"

That "Harp of Columbia" quilt was the one I always held in my lap and worked on when anybody come to see me during the while Joe was growing inside me. I told Joe about using it to hide him. Joe thought a heap of that quilt. I think it was the prettiest one I ever made. With Joe's stitches on it. My stitches-short and straight. And Joe's over there in the corner-long and crooked. Miss Robinson didn't take notice of them, I reckon. But somebody took Joe's stitches out, I know, before they hung it up for folks to look at. Nobody else would care. But I would rather had the hair pulled out of my head than had Joe's stitches pulled out of that quilt. The way he looked up at me with them eyes he had-Charles's eyes-and begged me to let him quilt. I couldn't help but let him do it. "And you won't pull mine out, will you, Ma?" I promised him his stitches never would be pulled out.

That night, after Miss Robinson and William Wayne left, while Ad and Linus were both out of the room, I set there on the bed and run my fingers over Joe's stitches. I reckon they wouldn't be counted pretty stitches by anyone else. I felt like getting inside the feather tick and being took off too. I couldn't sleep that night. I laid awake and squeezed that quilt in my hand.

It was lucky for me the next day. Ruby Arwood was called to straw and I had to be over there with Ruby all day. When I come in that night it seemed more different from home than ever. Nearly all my things gone-spinning wheel, warping bars and everthing. Even my big bone knitting needles, and my tatting shuttle that I made for myself. I didn't give up then and I am not going to give up now. Dona Fawver will be dying 
pretty soon and Dona couldn't stand for anybody to lay her out save me. I ought to go see her today.

I couldn't help but see the bedsteads the first thing when I come in the room that evening. There was that big old brass bed, all scarred up, setting over there in the corner, and that little old rickety bent up green one in front of the window. Both of them had the rods so scarred up they looked like they had been through the war. No telling who had used them. No telling what kind of old dirty folks had been sleeping in them. But Linus was setting in there bragging about them being so pretty. New stuff, he said, brought-on stuff. One of them was worth a dozen home-made things, he said.

I didn't look at them any more than I had to. I went on and got supper. When I turned the beds down I seed they had some big old dirty-looking gray blankets on them. I felt of them. They weren't even wool-just plain cotton. They were somebody else's old things too. I would rather sleep on the floor than to sleep on them old pads with cotton all wadded up in them. Ad and Linus said they were what all folks used that weren't old fogies. But I ought to be hunting the guineas' nestes. And I promised Mollie McGregor my receipt for corn relish.

It didn't seem right with them bedsteads in the room. And my little green and gold mug gone. It was my ma's mug. I used to think it so pretty. The time I had the measles Ma let me drink water out of it. I got thirsty every few minutes till Ma caught on and took to bringing it in the dipper.

I used to get down and rub my hands over it. That was after Charles drunk out of it. I fixed Charles some peach brandy in it. And some wild-cherry wine one night. Charles liked that wine. I had it hid out in the yard under that rock. I dug a hole there and had it in it. The Rebels never did one time think about looking there. Charles got spoiled to it, and he wanted wild-cherry wine every time he would come back. "In that green pitcher with gold houses on it," he would say. "In that pitcher lined with gold."

I let him have wine too. It seemed like it made his brown 
eyes sparkle more. Charles had dark eyes, and hair all combed back slick as ice. He was tall-big and tall. That was what made me take to him. I felt stronger when I was close to him. When he handed me the dipper his hand touched mine and it made me feel strong. His hands were big, but they weren't rough. They didn't have any big old knotty veins showing under the skin. They had nigh the strength of Letitia Edes's. Sometimes I thought Charles would mash me, the way he held me.

I was fixing to scour that second time when Miss Robinson come hunting for what she called antiques. I had sandrock beat up and scattered all over the floor and I had the water nigh hot enough to commence. What little furniture I had left was out in the yard. Miss Robinson's eye took to the trundle bed. She said she would give Linus a dollar for it. Said she guessed she could pay a dollar even if it was a mighty old and wore-looking. It made me hurt inside when I seed Miss Robinson hand Linus the money. My eyes and nose stung like they had pepper in them. Seemed like my heart was trying to swell up and bust.

It was the bed Grandma had slept on when she was little. Then $\mathrm{Ma}$, and then me, on up till I was fifteen year old. Joe slept on it all his life up till I married Ad. Them little horses' heads cut out on the head and foot. I couldn't bear to watch them tote it out to the wagon.

That little old bed seemed like it was just as much a part of me as my own right hand. Ma used to pull it out from under her own bed and tuck me in. "Good night, Mary Dorthula. Good night. Sleep tight. All right." I would lay there and look out the window. Lay there and watch the witches make tea. Lay there good and warm and think about princes that would come riding by someday.

It was the trundle bed that me and the soldier boy piled down on-Joe's pa. I loved Charles, and I don't care what other folkses have said about me because I had Joe before I married Ad. I wonder if the Yankees killed him. He said he would come back as soon as the war was over. One of my own 
brothers might have killed him, there's not any telling. I wonder how Charles would look with his eyes shut and all the color gone out of his face. And not able to talk. I don't want to see him that way. I wonder how he would think I looked that way. He talked about the color in my cheeks.

Charles wasn't like the other Rebels. I don't hold any grudgment against him for what he did. It wasn't anybody's fault but mine. There is not any fault to it-I love Charles. He made the rest of the Rebels not take Old Kate, the only horse left here on the place. And he make them shut up their mouths when they went to talking blackgyuardish in front of me and trying to jest me. Charles was gentle. His voice was deep as a well, and everthing he said come from down in him. It didn't sound so hollow like it come from the roof of his mouth.

Somehow or nother I didn't feel afeared of the Rebels with Charles in the bunch. Even if I was here by myself. It was the day that Belle Wisecarver lay a corpse and Aunt Cindy-Aunt Cindy was staying with me while both my brothers were away fighting the Rebels-she went over to Wisecarvers' that evening and said she would be needed that night. She said if any soldiers should happen to come by, for me to let them have whatever they wanted.

It was along about sundown when the soldiers come. I was setting all scrooched up in that hickory rocking chair with Ma's red-and-tan checked homespun shawl throwed around my shoulders. Sewing on my "Harp of Columbia" quilt. I had got to the curve of the harp and I couldn't make the curve without puckering the thing to save my life. Them three-cornered pieces wouldn't fit together. I had just said to myself that I was going to put it up and go after the cow.

Just as I started to fold it up I heard a big commotion out in the front yard. It sounded like a bunch of cattle coming up. "Hales' blamed old cattle out again," I said to myself and raised up to look out. Instead of it being cattle, it was men-soldier men. They were already on the porch.

Seeing them made me feel like I was being stuck all over with pins. I stood there by the side of the chair and looked like 
a scared deer, I guess. I didn't even offer to move. They come right on in the door. And the man with the red mustache, he said, "We want some fresh water." I held the quilt in my hands and went out on the back porch after the bucket. "I'll go to the spring and get fresh water," I turned around and said. That was when I first took note of Charles.

"I'll go. Give me the bucket." He took the bucket out of my hand. "Where is it?"

"Hit's right over there under that oak tree."

"Here, you hold the dipper."

The other Rebels searched around in the house while Charles went to the spring. They wanted to take them two hams out of the smokehouse. Charles got back in time to stop them from that. "Just leave them where they are," he said in that voice. All the other soldiers must have been afeared of Charles. They all minded what he said for them to do. Then the soldier men went over there and looked at Old Kate. Held open her mouth, looked at her feet, and everything. Some of them thought they ought to take her; some thought she wasn't worth taking.

Charles stood and talked to me during the while. He run his hand through my hair and said it was the softest hair he ever seed. I've always took good care of my hair ever since then. Charles seemed to forget all the other men, and he stayed there on the back porch with me. He kept on looking at my hair. I ought to get it combed now. "Little Red Ridinghood wore a shawl like that," Charles said. That shawl come in handy to wrap Joe up in too.

Directly the other Rebels come out of the barn lot and one of them was setting up on Old Kate. They had the bridle and everything. Well, Charles went out there and pulled that man off. He opened the gate and turned Old Kate back into the lot. Hung the bridle up there on the post just like he was at home. That was another thing I liked about Charles. He did everything easy-just like a red bird. It wasn't any trouble for him to move around from one place to another. I didn't know anybody could ever be that big without being gawlky. 
Charles went on away with the rest of the soldiers. I stood on the edge of the porch and watched him out of sight. I could tell from the way he kept looking around that he would come back to see me. He asked me out there on the back porch who I lived with. "Aunt Cindy," I told him. "Aunt Cindy stays here with me while the boys are away fighting the Rebels. But she has gone over to Wisecarvers' because Belle is dead."

"Is she coming back tonight?"

"She'll be needed to set up with the corpse."

"Are you afraid?"

"I'm not afraid of you." I don't know what made me give him an answer like that. I reckon it was just because I wanted to.

It was a little after dark when Charles come back that night and there were a few stars shining in the sky. I went to bed just as it got good dark. Before I fixed the bed I went out on the porch and looked up the Lead Hill to see if I could see Charles coming. I listened but I couldn't hear a sign of anything. So I pulled out the trundle bed and crawled in. I was still sleeping in the trundle bed then.

I was a-laying there. The stars were coming out pretty thick by now. The bull frogs were just beginning to holler so I knowed it was as dark as it would be. I laid there waiting. I just had a feeling. Directly it come. "Mary Dorthula," and then, "Hello."

"Come on in, Charles." I knowed in reason it was Charles.

"I slipped off. The others were asleep." When he talked in the dark his voice sounded like a hen clucking to her little chickens.

Charles kept on coming back. Aunt Cindy didn't say anything against it. For nine straight nights he come back. The Rebels stayed in the mountains that long, hunting for folkses that were hiding out to keep from joining either one of the sides. Folkses like the ones that dodged and went over into old Kentuck.

That was one reason I never have told anybody who Joe's pa was. Charles being a Rebel and both of my brothers 
Yankees. Folks around would have hated Joe sure enough. Joe wasn't like other bastards. But I reckon it was a good thing he died or got killed when he did.

I was never ashamed of having Joe before I got married. He favored his pa. At least he had his eyes and pert nigh his voice-and his protecting ways. Always tried to save me from something. Like the mammy hen saying, "Hide in the weeds. I'll fight the hawk."

Charles would have come back and married me if it had been so he could. That last night, he told me he would come the next night if they didn't march on. Said if they did march on he would come back soon as the war was over, or as soon as it was so he could come. I kept looking for him and kept high hopes for seven whole years. But he ain't come yet.

That is the reason I can't help but believe he was killed by the Yankees. He loved me. And he would have come back if something hadn't happened to him. He said he would, said I was the sweetest girl he ever seed. Told me that night it was getting a little coolish and I had a fire. The fire shined against his face and I could see it in the dark. He said he liked my yellow curly hair and blue eyes.

But I liked Charles's brown hair and eyes and his dark skin better. His skin was dark as a piece of fresh sod. I liked to run my hands over it. It was just natural dark. It wasn't made that way by the sun. Charles wouldn't have said he was coming back if he hadn't been aiming on doing it. He didn't talk with just his tongue.

Charles said he liked that trundle bed. "It lays so good." Every night he would sleep with me till nigh daylight. Then I would wake him up and he would go back. "I'll be back." He told me that every night. He told me that the ninth night he was here too. And I laid awake all night the next night waiting for him to holler, "Mary Dorthula, hello." I liked to hear him holler that. Like an old hen calling to her little chickens, "Come on here now, so the hawk won't get you."

I never did get to go anywhere with Charles, to any poke suppers or anything like that. We had to be sneaking as 
'possums for fear the other Rebels would catch on. Maybe they did. Maybe that is the reason he never did come back.

But the third night he come he set out there on the edge of my bed and told me stories, ones he had read, he said. The one about Bob and Julia. Robert loved Julia. "Just like I love you." And I couldn't help but cry when Robert got killed and didn't get to marry Julia. But I didn't want Charles to see me cry.

That was the night I had a fire. It was the first real cold night we had had that fall and I built a fire late that evening. When dark come I pulled the trundle bed out in front of the fireplace and laid down on it. It was a dark night and cold too. Ididn't know whether he would come or not that night. Directly, the frogs begun to holler. I looked out the window and I couldn't see but two stars anywhere. Just two stars in the sky, it was so dark and cold.

"Mary Dorthula. Hello."

"Come on in, Charles."

"It's warm in here."

"I'm proud you come."

"I like the firelight. I can see your eyes."

"Set down, Charles."

"This trundle bed. It is soft."

Charles set down on the edge of the bed with his face toward me and his knees upon the bed. And told me them stories. I listened-"And Rob loved Julia just like-well, he liked curly hair." And he said speeches to me. Poems, he called them. I watched his face in the firelight. His mouth said, "Whom there was none to praise and very few to love." And his eyes looked at me and I knowed what he meant. But he just didn't come out plain and say it. I liked it that way.

Charles tried to sing some too. But he couldn't sing as well as he talked. I don't believe he knowed much to sing.

"The Yankee run,

The Yankee flew,

The Yankee tore

His shirttail in two."

Charles wouldn't haveever run from anybody or anything. 
The next night was cold too. It was dark as pitch again. I didn't lay down. I set by the fire and played the accordion and sung. I didn't hear him come through the cow-field gate that night. There he stood in the doorway before I knowed it. I was just singing away:

"Then to the wars, to the wars he did go

To see whether he could forget his love or no.

For seven long years he served unto his king

And in seven more years was returning home again."

Of course, I had been singing that over and over ever since it got good dark. I wanted to be sure and be singing it when he come. Well, Charles, he stood there in the door. He looked like he didn't know whether to run out the door or jump up into the air. We looked at one another.

"Mary Dorthula."

"I didn't mean to be singing that."

"Sing it again."

Charles set there on the trundle bed by the side of me and made me sing it over and over till he learned it. "Just one more time, and then I'll know it." And he didn't tell me till the last night that he had been standing out there at the door ever since good dark listening to me sing that over and over.

That was the time he made me talk all night. "As soon as you tell me one more story I'll go to sleep." But I knowed he wouldn't. I didn't want him to. Just some little old hant tales was all I knowed. I told them till away up into the night, after the fire had died down and it was so dark you couldn't see across the room.

Charles would hold his breath sometimes. Heliked the tale about the woman making fire at midnight in that old house. And the one about the man going to give his daughter to the boy who could find water on his place. "I'm not sleepy." I could tell he liked for me to talk. He set a heap a store by me. And I set a heap a store by him, and by the trundle bed on account of him. It was cold when the fire died out. "I'll have to get another quilt," I said.

"Where was the one you were making on?" 
"I'll soon have it pieced." But it wasn't soon. And now.

What is wrong with my eyes? No. The sun has just gone down behind Letitia Edes Mountain. It was about this time of evening when the soldiers come marching up. Time to go milk. "We want a drink of water. . . . Little Red Ridinghood. . The squares are so little."

Of course Ad and Linus didn't think about things like that when Miss Robinson come along. The trundle bed was just a trundle bed to them. Ad knowed Joe had slept on it up till he was a great big hulk of a boy. But that didn't bother Ad any more than a flea bite.

It made me feel numb all over when I seed what Linus was doing. I went back in the kitchen and hid my face in my coattail till Ad and Linus come back from carrying it out to the wagon. I could tell them the place would never be the same without it. That trundle bed had been a part of every speck of bliss I had ever had.

All the time Ad and Linus were selling off my old stuff they were cutting logs so they could build that fine new house. A fine new house - that was all they could talk about. I heard it till the words jumped up and down in the middle of my head and fit with one another. Ad and Linus talked about it more than Barshia had back when he had it on his mind. I never did believe they would get it built till I seed them put the top on it. They fooled me one time. They finally got all the logs sawed and hauled. They took them up to Jim Heath's sawmill and swopped them for planks-thin planks made out of pine. Not good oak like the logs they cut and took up there.

I stood it all right while they were building on the house. I just didn't watch them much. They set it up right in front of my log house. Right in front of it. It covered all the pretty level part of the yard. But the house was plumb out on the edge of the bank. That made it look like a chicken coop on top of a mole hill.

I tried to keep my mind off it as much as I could while they were building it. It didn't take them any time to put it up--just two days. Little old light thing. It will just about topple over 
if ever the wind comes up the hollow. I won't much care. What is that I hear? Sounds like the wind blowing. I wish it would and blow it over. Cattle? Hales' cattle? Them soldier boys. That is it. "I'll go. . . here, you hold the dipper." Like a hen saying, "Let me kill the bee before you swallow it."

Both days that they worked on the house a big crowd of menfolks come to help. And a big crowd of womenfolks come in to help me with the cooking. I was proud to see them come. I listened to them talk instead of watching the menfolks work on the house. I like to hear womenfolks talk. After hearing Charles talk all other menfolks sound harsh and hateful.

The womenfolks talked about everything them two days. They were honest. They didn't wish harm to anybody. Seems like I can hear them now:

Granny, they say Penelope Courtney is going to need you again soon-you'll have to start a new life with the new house-the men are working like ticks in a tar bucket-"I'll be back." Granny, what happened to the little green and gold pitcher you had?-Have you heard about Arwoods' cow adying?-Sue Ella says her hens are not laying to do any good, must be bewitched-"I slipped off."-Have you heard that new song about the flying man's baby that got killed?-Do you like your new bedsteads better than your old ones?-Did you know that Brocks and Whetsels are at outs again?-What do you pack your clean clothes away in now?-"They were all asleep."-I've been sending milk and butter over to the Arwoods-Like a hen saying, "Come on out of the weeds now, the hawk's done gone."-How much did you get for your ma's three-cornered cupboard?-Wonder who will give Arwoods a calf to bring up in place of the cow that died?-Are you getting so new-fangled you aren't going to spin any more?-I seed the Smoky Mountain folks pass with your ash hopper-Hit's a pity Joe is not here-Wonder what ever become of Wilbur?What ever become of that butter dish Joe used to cry for the knobs off of?-"Ma, break me off them marbles, will you?""This trundle bed it lays so good."

I listened to them all day. They meant well. But, of course, 
they didn't know everything. I would hate not to ever see any of them again. Ruby Arwood will be having a baby soon and then Penelope. Dona Fawver will be dying soon too. And I will have to lay Dona out. And Teelie Edes-I want to see if she has got any witch marks on her. No telling how long I will have to stay in this world. I will have to go on doctoring till I learn somebody else how to take my place. But it is time to put supper on now, and I meant to pick a mess of sallet. I wish I had some gumption in me. This old new-fangled chair-not like the hickory rocker I was setting in. "I'm not sleepy."

Then the menfolks tore my house down. They got me moved into the new house and Ad and Linus norrated it around they were going to tear the old one down. A big bunch of men come in one day and they set to work on it. The womenfolks come back again too. I don't believe I could have tholed it if they hadn't. They seemed like they understood more that day. They didn't make any name of my old things being gone. They sung funny songs and told tales and laughed all the time both of the days they were here. Them asking me riddles and things sort of kept my mind off the house being torn down. Imah Baines sung one of the songs I learned Charles-the one that Charles said he liked next best:

"Come, rede us fathers, come rede us mothers,

The Yankee tore his shirttail in two."

"Just sing it one more time. I'll know it then."

Grandma had been born in that house. Pa was born there. Ma was carried over the door sill and swept the walls down with a sage-grass broom. Charles said when he come back he wanted to live up here at the end of the hollow in that house forever. "And slop the hogs and things....Just put that ham back...Raise hogs and boys."

Them things didn't matter to Ad and Linus. They tore it down a $\log$ at a time. They had a job of it too. The logs were big. I managed to stay as busy as I could. And I kept cotton in my ears part of the time to keep from hearing them tear the logs 
apart. I couldn't help but hear when they pushed over the stick chimney. I used to hold Joe's hand and we would stand and watch the smoke come twirling out of it. Joe would stand as still as a froze snake and watch it. "We help make the sky, don't we, Ma?"

Ad and the men had a big time when they found some notes that Tiny Brock had wrote to Joe at school. Joe had stuck them in a chink there in the wall. Linus read them out loud to all them old men. "Hello, Dern Sweetheart," they all started off. There wasn't e'er a time he didn't put in the word "dern." That meant Tiny was his secret sweetheart. He didn't want Miss Omie to know it, and he didn't want anyone else to know it. But their sparking wasn't dern at all, of course. It is hard to keep a fire smothered-the blaze will always show. Charles never did call me his dern sweetheart. But I was. He had to keep it a secret or the other Rebels wouldn't have let him come. And he never did write to me. Never had any chance to. But the way he said my name, "Mary Dorthula. Hello." And the way he looked at me and didn't say anything. Words don't mean much anyhow. You're safe as long as you stay under my wing.

The men all laughed at Joe's little notes when they heard them. They pitched them out on the ground and piled logs on top of them. They found a little speech too. One Joe had hid there. His teacher cut it out of something and give it to him to learn and say. He used to say it over to me. "The spider wove his silvery web until his work was done." Hit was pretty. And Joe's voice sounded almost like Charles's did when he said speeches. I'll fight the hawk, Mary Dorthula.

Joe had hid that speech in the chink and it had slipped back furder than he aimed for it to. They pitched it out on the ground. They pitched everything on the ground. Joe loved the old house. I told him one day what Charles said about the house that first day when he seed it. "It is just made to fit into the shape of this hollow. No other house would look right here. It will be here when I come back....It will always be here....I'll be back." 
"I'm proud you come."

This old new-fangled chair. Cheap. It is enough to break a body's neck. It is getting dusk outside. Time to have milking done. It will soon be dark. Time for Charles and Joe to come in from loafing at the store.

The last evening the men worked on the house, all the womenfolks went home and left me here by myself. Ad hollered for me to fetch some water. I took that old tin bucket. Water don't taste good out of it like it did out of my staved bucket-the one they sold.

I took the tin bucket and went. As I started down the steps I seed they had the house about tore down-just hadn't moved the sills yet. I sort of hoped they would let the sills stay there. I had heard Grandpa talk about them sills. The best that could be made, he said. It took six men to lift one of them. They had stayed solid even if Ad hadn't patched the roof, and the rain had come right on through. I feared Grandpa would rise up out of his grave when the sills were moved. Charles said there wasn't any such material as that nowadays. "They'll be here always. I'll be here always. Hogs and boys." I'll bet the old sow is hungry. It is dark outside. It gets dark soon in the fall of the year this way. I like long nights. I wouldn't want to be in a place where there never come any night.

I tried not to look at the pile of logs. When I got over to the spring something made me look back. I seed that big pile of logs there to be burnt. Somehow or nother, thinking about it took nigh all the strength I had in me. I set down there on the bank of the branch.

I set down without thinking. I don't know how long I set there. Then I heard Ad yelling, "What in the hell are you doing? You'd be a good one to send after water if the devil's guts were on fire." "Here, you hold the dipper." I was numb all over. I had to try two or three times before I could even drag myself up. I finally managed to pick the bucket up and start.

Listen. Yeah, that is him. The cow-field gate. Opening. Shut. Ad and Linus. It is time. Loafing at the store all day. And his shirt not patched. "Mary Dorthula. Hello." "I'm 
proud you come." "Little Red Ridinghood."

When I got to the house with the water I seed Ad and Linus take hold of the last sill. They couldn't budge it. Nigh all the men had to help. I was holding the bucket for Old Man Arwood to get him a drink. That strength in Charles's hands. And when I seed them lift that sill up and lay it over out of the way, something went wrong with me. I don't know what it was. But I went weak all over. And that bucket fell out of my hand. "You hold the dipper. I'll take the bucket." It hit the ground kerwhollop. I sort of went blank there for a short span.

I hear something on the porch. Them back. And supper not ready. I am a little chilly. The fire. I guess I had better punch it. My neck-it is so limber. This chair. "Just one more time and then I'll know it."

But I come back to myself before anybody took note of it, I think. Old Man Arwood said he would take the bucket back to the spring. "I'll go. Where is it?"

"Right there under that tree."

"Here, you hold the dipper."

I reckon the men just thought I was awkward and dropped the bucket. I believe Ad sort of noticed me. I don't know though.

There are two stars. Just two in the sky. It is dark tonight. And cold. And I didn't get his overalls patched. Them frogs. They know it is time. I will punch up the fire. I' $m$ tired of this chair anyhow-lets my head fall over like I've got the limber neck.

"Mary Dorthula. Hello."

"Come on in....I'll soon have it done."

"I slipped off... that little red blanket...the others were sleeping."

"I'm proud you come...I didn't mean to be singing."

"Again... But if I touch you-"

"This trundle bed, Charles, it lays so good." 


\section{The Hawk's Done Gone}

1. What did Mary Dorthula White's possessions mean to the antique hunters? To Ad and Linus? To Mary Dorthula?

2. What was Mary Dorthula's biggest concern related to the loss of her "Harp of Columbia" quilt?

3. In what ways were Wayne Williams, the antiquer, and Charles, the Rebel soldier, similar? 


\section{JAMES STILL (1906- ）}

James Still, who was born in Double Creek, Alabama, has been called "the psalmist of the mountains." A 1929 graduate of Lincoln Memorial University, Still earned an M.A. at Vanderbilt University in 1930. He has lived since 1939 in an old log house on Dead Mare Branch near the Hindman Settlement School in Kentucky. Before devoting himself to writing full time, Mr. Still was the librarian at the settlement school. He also taught for ten years at Morehead State University.

He has published poetry, short stories, books for children, and novels. His short stories have been anthologized in such collections as the Best American Short Stories and the O. Henry Memorial Prize Stories. Mr. Still is also a frequent commentator on National Public Radio.

When James Still turned 80 on July 16, 1986, the Hindman Settlement School threw a party to honor the man and his work. Several hundred people gathered from all over to pay tribute to one of the Appalachian region's finest authors.

When his novel River of Earth was published 46 years ago, Time magazine called it a "work of art." It won the Southern Authors award. Still in print, the book continues to attract readers and critical acclaim. This excerpt shows why. 


\section{From River of Earth}

The mines on Little Car closed in March. Winter had been mild, the snows scant and frost-thin upon the ground. Robins stayed the season through, and sapsuckers came early to drill the black birch beside our house. Though Father had worked in the mines, we did not live in the camps. He owned the scrap of land our house stood upon, a garden patch, and the black birch that was the only tree on all the barren slope above Blackjack. There were three of us children running barefoot over the puncheon floors, and since the year's beginning Mother carried a fourth balanced on one hip as she worked over the rusty stove in the shedroom. There were eight in the family to cook for. Two of Father's cousins, Harl and Tibb Logan, came with the closing of the mines and did not go away.

"It's all we can do to keep bread in the children's mouths," Mother told Father. "Even if they are your blood kin, we can't feed them much longer." Mother knew the strings of shucky beans dried in the fall would not last until a new garden could be raised. A half-dozen soup bones and some meat rinds were left in the smokehouse; skippers had got into a pork shoulder during the unnaturally warm December, and it had to be thrown away. Mother ate just enough for the baby, picking at her food and chewing it in little bites. Father ate sparingly, cleaning his plate of every crumb. His face was almost as thin as Mother's. Harl and Tibb fed well, and grumblingly, upon beans and corn pone. They kicked each other under the table, carrying on a secret joke from day to day, and grimacing at us as they ate. We were pained, and felt foolish because we could not join in their laughter. "You'll have to ask them to go," Mother told Father. "These lazy louts are taking food out of the baby's mouth. What we have won't last forever." Father did not speak for a long time; then he said simply: "I can't turn my kin out." He would say no more. Mother began to feed us between meals, putting less on the table. They would chuckle without saying anything. Sometimes one of them would make a clucking noise in his throat, but none of us laughed, not even 
Euly. We would look at Father, his chin drooped over his shirt collar, his eyes lowered. And Fletch's face would be as grave as Father's. Only the baby's face would become bird-eyed and bright.

When Uncle Samp, Father's great-uncle, came for a couple of days and stayed on after the week-end was over, Mother spoke sternly to Father. Father became angry and stamped his foot on the floor. "As long as we've got a crust, it'll never be said I turned my folks from my door," he said. We children were frightened. We had never seen Father storm like this, or heard him raise his voice at Mother. Father was so angry he took his rifle-gun and went off into the woods for the day, bringing in four squirrels for supper. He had barked them, firing at the tree trunk beside the animals' heads, and bringing them down without a wound.

Uncle Samp was a large man. His skin was soft and white, with small pink veins webbing his cheeks and nose. There were no powder burns on his face and hands, and no coal dust ground into the heavy wrinkles of his neck. He had a thin gray mustache, over a hand-span in length, wrapped like a loose cord around his ears. He vowed it had not been trimmed in thirty years. It put a spell on us all, Father's cousins included. We looked at the mustache and felt an itching uneasiness. That night at the table Harl and Tibb ate squirrel's breasts and laughed, winking at each other as they brushed up brown gravy on pieces of corn pone. Uncle Samp told us what this good eating put him in mind of , and he bellowed, his laughter coming deep out of him. The rio lamp trembled on the table. We laughed, watching his face redden with every gust, watching the mustache hang miraculously over his ears. Suddenly my brother Fletch began to cry over his plate. His shins had been kicked under the table. Mother's face paled, her eyes becoming hard and dark. She gave the baby to Father and took Fletch into another room. We ate quietly during the rest of the meal, Father looking sternly down the table.

After supper Mother and Father took a lamp and went out to the smokehouse. We followed, finding them bent over the 
meat box. Father dug into the salt with a plow blade, Mother holding the light above him. He uncovered three curled rinds of pork. We stayed in the smokehouse a long time, feeling contented and together. The room was large, and we jumped around like savages and swung head-down from the rafters.

Father crawled around on his hands and knees with the baby on his back. Mother sat on a sack of black walnuts and watched us. "Hit's the first time we've been alone in two months," she said. "If we lived in here, there wouldn't be room for anybody else. And it would be healthier than that leaky shack we stay in." Father kept crawling with the baby, kicking up his feet like a spoiled nag. Fletch hurt his leg again. He gritted his teeth and showed us the purple spot where he had been kicked. Father rubbed the bruise and made it feel better. "Their hearts are black as Satan," Mother said. "I'd rather live in this smokehouse than stay down there with them. A big house draws kinfolks like a horse draws nitflies."

It was late when we went to the house. The sky was overcast and starless. During the night, rain came suddenly, draining through the rotten shingles. Father got up in the dark and pushed the beds about. He bumped against the footboard and wakened me. I heard Uncle Samp snoring in the next room. They were mightily tickled about something. They laughed in long, choking spasms. The sound came to me as though afar off, and I reckon they had their heads under the covers so as not to waken Uncle Samp. I listened and wondered how it was possible to laugh with all the dark and rain.

Morning was bright and rain-fresh. The sharp sunlight fell slantwise upon the worn limestone earth of the hills, and our house squatted weathered and dark on the bald slope. Yellowbellied sapsuckers drilled their oblong holes in the black birch by the house, now leafing from tight-curled buds. Fletch and I had climbed into the tree before breakfast, and when Mother called us we were hungry for our boiled wheat.

We were alone at the table, Harl and Tibb having left at daylight for Blackjack. They had left without their breakfast, 
and this haste seemed strange to Mother. "This is the first meal they've missed," she said.

Uncle Samp slept on in the next room, his head buried under a quilt to keep the light out of his face. Mother fed the baby at her breast, standing by Father at the table. We ate our wheat without sugar, and when we had finished, Mother said to Father: "We have enough bran for three more pans of bread. If the children eat it by themselves, it might last a week. It won't last us all more than three meals. Your kin will have to go today."

Father put his spoon down with a clatter. "My folks eat when we eat," he said, "and as long as we eat." The corners of his mouth were drawn tight into his face. His eyes burned, but there was no anger in them. "I'll get some meal at the store," he said.

Mother leaned against the wall, clutching the baby. Her voice was like ice. "They won't let you have it on credit. You've tried before. We've got to live small. We've got to start over again, hand to mouth, the way we began." She laid her hand upon the air, marking the words with nervous fingers. "We've got to tie ourselves up in such a knot nobody else can get in." Father got his hat and stalked to the door. "We've got to do hit today," she called. But Father was gone, out of the house and over the hill toward Blackjack.

Mother put the baby in the empty wood box while she washed dishes. Euly helped her, clearing the table and setting out a bowl of boiled wheat for UncleSamp. I went outside with Fletch, and we were driving the sapsuckers from the birch when Uncle Samp shouted in the house. His voice crashed through the wall, pouring between the seamy timbers in raw blasts of anger. Fletch was up in the tree, near the tiptop, so I ran ahead of him into the shedroom. Mother stood in the middle of the floor listening. Baby Green jumped up and down in the wood box. Euly ran behind the stove.

I ran into the room where Uncle Samp was and saw him stride from the looking glass to the bed. His mouth was slack. A low growl flowed out of him. He stopped when he saw me, 
drawing himself up in his wrath. Then I saw his face, and I was frightened. I was suddenly paralyzed with fear. His face was fiery, the red web of veins straining in his flesh, and his mustache, which had been cut off within an inch of his lips, sticking out like two small gray horns. He rushed upon me, caught me up in his arms, and flung me against the wall. I fell upon the floor, breathless, not uttering a sound. Mother was beside me in a moment, her hands weak and palsied as she lifted me.

I was only frightened, and not hurt. Mother cried a little, making a dry sniffling sound through her nose; then she got up and walked outside and around the house. Uncle Samp was not in sight. She came back and gave Fletch the key to the smokehouse. "We're going to move up there," she said. "Go unlock the door." I helped Euly carry the baby out in the wood box. We set him on the shady side of the woodpile. We began to move the furniture, putting the smaller things in the smokehouse, but leaving the chairs, beds, and tables on the ground halfway between. The stove was heaviest of all, and still hot. The rusty legs broke off on one side, and the other two bent under it. We managed to slide it into the yard. Mother carried the clock and the rio lamp to the smokehouse. The clock rattled with four pennies Fletch kept inside it.

After everything had been taken out we waited in the backyard while Mother went around the house again, looking off the hill. Uncle Samp was nowhere in sight, and neither Harl nor Tibb could be seen. Then she went inside alone. She stayed a long time. We could hear her moving across the floor. When she came out and closed the door there was a haze of smoke behind her, blue and smelling of burnt wood.

In a moment we saw the flames through the back window. The rooms were lighted up, and fire ran up the walls, eating into the old timbers. It climbed to the ceiling, burst through the roof, and ate the rotten shingles like leaves. Fletch and I watched the sapsuckers fly in noisy haste from the black birch, and he began to cry hoarsely as the young leaves wilted and hung limp from scorched twigs. The birch trunk steamed in the heat. 
When the flames were highest, leaping through the charred rafters, a gun fired repeatedly in the valley. Someone there had noticed the smoke and was arousing the folk along Little Carr Creek. When they arrived, the walls had fallen in, and Mother stood among the scattered furnishings, her face calm and triumphant.

\section{River of Earth}

1. In this selection Mother and Father both feel a sense of responsibility to family. Why is this a source of conflict in the household?

2. At one point Mother says to Father, "We've got to tie ourselves up in such a knot nobody else can get in." What does she mean by this statement?

3. What event prompted Mother to move to the smokehouse? Was this move a solution to her problems? 


\section{JESSE STUART (1907-1984)}

Jesse Stuart was born in W-Hollow, a farm near Riverton, Kentucky, and attended a one-room country school which he later used as the setting for some of his stories. He worked to put himself through Lincoln Memorial University in Tennessee, where James Still and Don West were among his classmates. He studied for one year at Vanderbuilt University. There he wrote his autobiography which he later published as Beyond Dark Hills.

Stuart taught school, which included stints at the American University in Cairo, Egypt, and at the University of Nevada. He also farmed, worked in industry, and served in the Navy. During 1962 and 1963, he served as a specialist abroad for the Bureau of Education and Cultural Affairs.

Jesse Stuart received many honors and awards in all areas of writing. He appeared on the American literary scene in 1934 with Man With a Bull-Tongue Plow. His poetry, short stories, and juvenile fiction were very popular and appeared frequently in magazines and literary journals. In 1943, his short story collection Men of the Mountains won the Academy of Arts and Sciences Award, and the novel Taps for Private Tussie received the Thomas Jefferson Memorial Award.

The National Education Association selected The Thread That Runs So True as the best book of 1949. Stuart also received the Academy of American Poets Award in 1961. Kentucky 
honored him with the designation of Poet Laureate in 1954.

This excerpt from Daughter of the Legend is about a young couple at a worship service where faith is tested.

\section{From Daughter of the Legend}

We've got a river to cross and a mountain to climb," Deutsia said. "We go over to the Clinch right here." river.

She led the way along the narrow footpath toward the

"How do we cross?" I asked. "Boat?"

Deutsia laughed at my words.

"I'll show you."

On the bank of the Clinch we stood where a tall sycamore had uprooted and had fallen across two-thirds of the width of this mountain river. We walked over the body of a giant tree that had often served as a bridge. I could tell by the way the bark was worn. We grabbed the bushy leafless top branches of the tree and held to a branch above us, then walked on as far as I thought it safe for two people to walk.

"Sit on this limb, pull off your shoes and roll your pant legs up," she said.

Deutsia started taking off her oxfords.

I rolled my pants until they were tight around my legs.

"Can you hold your shoes and mine?" she asked me.

"I think so," I said.

I held the four shoes by the strings.

"Now keep your hand on my shoulder."

I laid my hand on her shoulder as she lifted her dress and stepped down from the sycamore top into the water.

"Step where I do," she said. "Be careful."

When I put my foot where she had just put hers, it went down on a rock. And I followed her, stepping where she stepped. She was keeping her dress dry, but her hair was dragging the water behind her.

When we reached the river bank, Deutsia shook the water 
from her hair and we sat on a rock and put our shoes back on.

"Come," Deutsia said gleefully, taking my hand.

I followed her up a path beneath the pines, around and over the rocks, under the bright-leafed maples, the brown-leafed white oaks and red-leafed gums.

"I want my pipe and a good smoke," I said when we reached the top where the wind chilled the sweat on our faces.

"Isn't it wonderful up here?" Deutsia said.

I struck a match to light my pipe but the wind erased the flame.

"Too much wind up here. I can't light my pipe."

"We'll fix that."

With her back to the wind she spread her dress, making it a barrier against the wind so I could light my pipe.

"You know how to do everything," I said.

She smiled.

We hurried over the wind-swept rocks where scrawny seedling pine needles stuck our legs and huckleberry vines, sawbriars and greenbriars pulled at our shoelaces. Then we came to a ridge road where we looked at the setting sun, large as a spread umbrella and the color of a hot red hollyhock.

"We'll make it on time," she said.

In less than ten minutes we came to a pine grove where dry pine needles crunched beneath our feet and where within the dense grove we could hear singing. Our road made a sharp turn and we came directly upon a gathering of people, sitting on split-log benches. The pines had been cut away, except for a few on which lanterns hung, and around the cleared enclosure that was the churchhouse were thick walls of the thickly studded trees. By the time we had walked down to sit on a bench, the singing had begun. We were in an outdoors churchhouse.

By the lantern light I could see many of the faces that I'd noticed around the courthouse. I also saw many strange faces. Two of the boys played a snappy tune on their guitars, almost like a fast square dance tune, while the people that faced us, and many of the congregation sitting on the benches, sang 
"Feasting on the Mountain."

In front of the choir the preacher stood with a rough handmade table before him, his hand upon his opened Bible. Down beside him were the wire cages like the ones I'd seen at the shacks on Sanctuary Mountain.

"What church is this?" I whispered to Deutsia.

"Holiness Faith Healers."

"What's in that cage up there?"

"Rattlesnakes."

"Why do they have rattlesnakes?"

"Wait a minute and you'll see."

As we whispered I saw eyes stare at us, telling us without saying a word to quit whispering in church. I wondered, too, if they also meant me to take my arm from around Deutsia, but I looked around and other men were sitting close to their girls with their arms around them.

Before the song was finished a fat woman in front of us jumped up, clapping her hands above her head, shouting, "Glory to God! Glory to God! We'll feast on the mountain up there!" And she pointed toward the sky when she said "up there." She danced a tune on the pine needles and shouted while they finished the song.

"Glory to God, Sister Witherspoon," the preacher said, as thechoir sat down on their log seats that were just a little higher than ours. "We'll feast on the mountain up there! Glory to God!"

Sister Witherspoon sat down, her body jerking and her hands a-quiver, her face covered with drops of sweat that shone brightly in the lantern light.

The preacher stood at the table before us, dressed in his faded clean-washed overalls and blue work shirt with his sleeves rolled to his elbows and his shirt collar unbuttoned. There was a beard on his face and his hair was uncombed. When he opened his mouth he showed two rows of discolored front teeth. He was a tall man but bent over like a windwhipped oak on the mountaintop, and his eyes looked down at us like a hawk's eyes when they look over a flock of chick- 
ens.

"I'll take my text," he said, "from the sixteenth chapter and the eighteenth verse of St. Mark."

He bent over his opened Bibleand began to read, stumbling slowly over the words as a barefoot boy stumbles over rocks when he first pulls off his shoes in the spring.

"'They shall take up serpents; and if they drink any deadly thing, it shall not hurt them; they shall lay hands on the sick, and they shall recover."

"That's the Word, folks," he said, his long black mustache working up and down as he spoke. "That's the Gospel for ye. And soon as we have another song, I'll give ye the message that God told me to give ye."

The choir rose from their log seats, the young men with the guitars looked at each other, one nodded a signal to the other and then there was a fast plucking of strings, a wild outburst of many-tongued discordant voices singing, "I'll be a Holiness until I Die." I knew that this was a dance tune, for my feet began to move, to pat on the pine needles, and I looked about me and other feet were doing the same.

"Glory, glory," the preacher shouted, looking upward toward the pine-needle ceiling. "Won't we all be Holiness until we die? Until we reach that Heaven in the sky?"

"You bet we will, Brother Dusty," yelled a dark-complexioned man with a deep booming voice like a mountain wind surging down into a hollow. "You bet we will, Brother Dusty! I'm saved and sanctified and I can't sin no more, Brother Dusty!"

And he clapped his big fire-shovel hands and twitched his mouth, wiggling the horns of his black mustache as his feet patted the tune on the pine needles. After a few pats with his feet, he let out a yell. "Whoopee! Glory to God! Sing children! Sing! Glory be to God, we'll all be Holiness till we die! We'll all be Holiness when we reach that Heaven in the sky! Glory! Glory! Glory be to God! Glory be to God!" he was shouting in a big voice like the wind, high above the voices in the choir. "Glory be, brothers! Glory be, sisters! Glory be to the God that 
gives us power to heal the sick and the afflicted, that gives us the power to handle the serpents and if we are right with God, they won't bite us! Blessed be the name of the Sweet Jesus that gives us power to handle fire and won't let it burn us! Send us the Light, Sweet Jesus!"

"Amen, Brother Cliff," Preacher Dusty said to the big man, who was standing now, jerking as I'd never seen a man jerk before.

"The serpents and the fire will test you, Brother Cliff," a tall woman screamed as she arose from her seat. She waved her hands into the air above her tousled hair. "If you ain't right with Jesus, the serpent will send his fangs into ye and turn loose his venom and the flame will wither yer flesh...scorch and burn it...Ah, the Devil is in ye when the serpent will fang ye and the flames scorch ye...Ah, it's the sign that ye ain't right with Jesus!"

She danced a tune, her head thrown back, her face toward the pine-bough ceiling. Her eyes were closed, her mouth was open and she mumbled words that I couldn't understand. Now Brother Dusty was walking between the rows of seated people, looking straight ahead at something I couldn't see. His hands were spread before him and he, too, was mumbling words I couldn't understand.

"What are they saying?" I asked Deutsia. I had to shout to get my words above the singing and the mumbling of many people.

"They are talking in the Unknown Tongue," she said.

"Can you understand them?"

"No."

"Listen, young man," a big man with a red beardy face said to me in a loud voice. "I belong to the real Unknown Tongues. And I've been a-sittin' here a-tryin' to make out what they're a-sayin' and the only word that they have said that I can understand is 'sweet tater.' I come here tonight a-thinkin' they would talk in the language of my Church! But they're aspeakin' a tongue only the Devil in his hell can understand!"

Before he had finished saying these words the big woman, 
with her eyes closed, sprawled on the ground, her body jerking and her lips and eyelids twitching. There she lay before Deutsia and me, her dress high upon her body showing her big legs, her cotton bloomers and her red outing petticoat. She stared vacantly toward her Heaven in the sky as she mumbled her unknown words.

"Speak to Jesus, Sister Hallie," a woman said, sitting on the seat above her. "Tell Him that you love Him. Thank Him for the magic power to heal! Speak to Him tonight as you've never spoken to Him before and help Him fight the mean old Devil to a finish on this night. Tell Him to he'p bind the Devil's hands, to he'p us shet his filthy mouth, and chain him in the endless pit fer eternity."

And she jumped up and started running in circles, shouting "Glory to Sweet Jesus" as she ran. Maybe she started the others; I don't know. It seemed that everybody arose from his seat but Deutsia and me. People-men, women and boysgrabbed each other and started swinging as I'd seen them swing in figure eight of an old square dance. But the dancers never piled upon the floor and kicked and moaned and said words no one could understand as these people did. Amid the singing and the wild confusion of people going around and around, stumbling over the women and men on the ground with pine needles in their hair and sticking to their clothes, many young couples still sat on the benches with their arms about each other, kissing.

Small children held babies in their laps while their mothers and fathers shouted and rolled. I saw little girls and little boys run madly through the crowd, stepping on men's hands and women's tangled hair, screaming as they went. They were afraid of all this confusion. Once I saw a small boy run out screaming into the dark pine woods, his hands high in the air, his heels touching his rump as he ran.

Brother Dusty tried to preach by shouting his words and waving his big gnarled hands to get his God-given message to his congregation above the din and roar of the rolling, kicking and quivering people. I could hear a few of Brother Dusty's 
words. "Hell is nineteen miles straight, straight under the ground," I heard him scream as he pointed down to the ground. I looked above me and insects were swarming around the smoky-globed lanterns. High on this mountain the insects, too, had found the Light and the lantern warmth as well.

I've been to many a church in the mountains, I thought, as I looked beneath the split wooden log we were sitting on to see what was a holding it up, but I have never seen anything like this. As I was touching the rough oak posts that had been placed in auger holes in the bottom of the logs we sat on, I heard a scream among the people and wild screams among the tenorvoiced children. I got up and saw Brother Dusty with a big rattler around his neck. He was patting the rattler's head while it flicked out its tongue to catch and listen to the sound of the confusion, a greater sound of voices than a rattler ever hears when left alone free to roam his mountain world among the rocks and wild huckleberry vines. Brother Dusty turned this way and that to show the rattler to all the people. From where we sat, I could see the rattler's tail a-quiver on the ground beneath us.

"Sweet Jesus gives me the power," Brother Dusty said. "There ain't no Devil in this man. Not nary bit o' th' Devil in this flesh. Saved and sanctified and can't sin any more. They shall take up serpents. Ain't this the fulfillment, folks? Ain't it? Oh for that home among the stars where the angels sing and play their guitars!"

"Amen, Brother Dusty."

I wondered if only Brother Dusty would handle a rattlesnake, fondle it and coddle it and let it listen to his congregation, let it wrap itself about his neck as if it were a necktie. This giant rattler must have been heavy about his neck, it looked him in the eyes with its cold, hard lidless eyes and put wild fears into the small children who looked up at it. But the rattler didn't scare Brother Dusty. All eyes of the shouting people turned toward him, but not the eyes of the people lying on the floor jerking. Their eyes were closed and their jerks came easier. Many had jerked until they could move no more and 
they lay on the pine-needle floor lifeless and exhausted, with drool running from the corners of their mouths.

"That's closer than I want to get to a rattlesnake," I said to Deutsia.

When I said these words to her, I looked at her soft faircomplexioned face, her blue eyes that focused the rattler around Brother Dusty's neck, and wondered if her religion was this snake religion. I could never attend this church with her if we married, I thought. I would never trust a rattlesnake. Too many had almost got me in the timber woods. There were fangs of the mountain rattler embedded in my boots.

When I turned my face from her to look over the congregation again, I saw something that made me want to run to the pine woods as I'd seen the small boy run. I saw many men and women, with rattlesnakes around their necks and in their arms. And they were fondling them with no more fear than I would have had if I'd handled a piece of rope.

"These're Sweet Jesus' children," Brother Dusty said. "There ain't no part of the Devil in 'em. Not a chip from the Devil's tree o' sin in 'em. Not a drop of the Devil's blood! Yes, we've had people bitten by the serpent but the serpent knows the ones that's got the Devil in'em. He knows the facts, people, for he can smell th' Devil in a man a mile away, and he can taste the Devil in' em when he bites!"

I wondered if these little children had the Devil in them as they ran screaming when their mothers and fathers came out among the congregation with these vicious, rusty-looking rattlers around their necks and in their arms. Many women held the snakes to their bosoms.

Women came from their trances and took up the snakes. The wire-caged doors were all opened now, and I'd never seen as many rattlers in one place. Now I knew why I'd seen the snakes in cages at the shacks on Sanctuary Mountain. These people that came to this church on this night and brought their snakes had kept them in cages so they wouldn't go to sleep. For this was October, a time when rattlers should be in their winter beds. 
There was so much to see. I turned my eyes toward the table that Brother Dusty had used for a pulpit, and saw women who didn't have rattlers to prove their faith standing with flaming pine torches, holding the flames to their hands, the rich heavy smelly pine smoke going up in dark heavy spirals toward their faces.

"The flame can't sear this flesh," one screamed, but I knew the flame was searing her flesh, the way she twitched.

"I know I'm a child of Sweet Jesus," a fair-haired woman screamed. "When the flame don't burn, it is the sign!"

"I feel the fire within," another screamed, "but not this worldly fire from the torch that can't sear the flesh because God won't burn His children!"

The children didn't fear the flames; they feared the ugly writhing snakes. They would gather close to watch these women stick the flames to their hands. With one hand these women held the pine torch and applied the flame to the other hand. That evening was something I would never forget. While Isat watching the women apply the torches to their flesh, I saw Brother Dusty with his rattler still around his neck. His big hand was playing with its head, and his big fingers were fingering its lips. I took my arm from around Deutsia to use if the rattler came too near, for I was afraid.

"What's the matter, young man?" Brother Dusty said as he stood before me with his rattlesnake too near for my comfort.

"Don't get that rattler close to me."

"Be saved tonight, young man," he said. "It's the Devil in you. You're possessed with seedy, vile sin."

"Keep back that rattler," I warned him again.

"What about you, honey?" the woman said to Deustia.

Deustia didn't answer her, but with her soft hand she stroked the rattler's head.

"That snake acts as if it knows you," I said to her. I got up from the seat and began to back away.

"It won't bite," she said.

"They ain't no Devil in this pretty girl," Brother Dusty said. "Let's go, Deutsia," I said, pulling her by the hand. "Let's 
clear out of here!"

Deutsia and I turned to walk back the way we came.

"I don't belong in this church," Deutsia said in a whisper as we started back to the rear.

"I'm glad you don't."

We faced a crowd of people standing at the rear. Many had their hands and faces bandaged.

"I don't belong to any church," she said.

"What's wrong with these people, anyway?" I asked.

"Burnt hands and bitten by rattlesnakes," she said. "They had Devil in 'em."

"What's all this crowd doing back here?" I asked in a low tone. belong."

"They come to watch what goes on," she said. "They don't

"Look to your left," I whispered.

Deutsia turned her head to look.

"See what I see?"

"Yes."

There stood Fern Hailston and Ben Dewberry among the crowd of onlookers. They were smiling as they watched the crowd of worshipers. Then I saw them looking at us, but when Ben saw me looking at them he quickly turned his head as if he didn't see me. I knew he was ashamed of me.

"Gee, I'm glad to get out of here," I said.

We were out in the pine woods now, where darkness hovered over the earth like a black brooding hen.

"How did you like this church?" she asked me.

"I've never seen anything like it."

"This is the last revival meeting before the rattlesnakes go to sleep. That's why I wanted you to see it."

"Wonder how Ben and Fern got up here?" I asked.

"I don't know," Deutsia said. "Miss Fern ought to be a good mountain climber."

"I didn't worry so much about climbing the mountain," I said. "It's the getting down."

"We'll get down the mountain easier than we got up," Deut- 
sia said

"We can do anything together."

"I feel strong with you," Deutsia said, "and I need you. I need you always."

We started down the mountain toward the curving ribbon of river. Down we went, away from the wind, the stars and moon.

\section{Daughter of the Legend}

1 From what point of view is this story told? In what ways does point of view contribute to the effect of this story?

2. What does the word literal mean? Would you say the worshipers in the story interpret the Bible literally? Support your answer with examples.

3. What is the setting of the story? Does it help make the story believable? 


\section{COMPOSITION TOPICS}

1. In "The Star in the Valley" and in the excerpt from A Cumberland Vendetta, heroic characters are willing to die for their principles. Which of these characters do you most admire? Write a composition supporting your choice.

2. Listen to the conversation around you. Notice both slang expressions and regional pronunciation such as those found in some of the stories you have just read. Write a short narrative with dialogue using expressions you have heard.

\section{ACTIVITIES}

You have read about heroes in this section. Even though they sometimes appear as ordinary people, most families have heroes. Write about someone in your family who is a hero. Tell who he or she is, his or her relationship to you, and what the person did that is heroic. Tell the hero's story in a narrative to make it more interesting. You may want to illustrate this story with photographs or your own drawings.

You have also read stories in this section about family loyalties. Write about a time a member of your family helped another person or about a time you helped some family member. 


\section{CHAPTER 3}

\section{Contemporary Authors Search for a Usable Past}

One important aspect of Appalachian writing has been reminiscing by looking back and recording the past. As Chapter 3 will show, this trend continues in the works of contemporary Appalachian writers.

All these selections are about memory. The memory may be personal-a visit with an old friend or a talk with a grandmother. Or it may be a more general reminiscence such as finding ginseng in the woods or enjoying country life.

By sifting through these memories, writers find materials that make good stories and poems and that help readers find value in themselves and their heritage. 
THOMAS WOLFE (1900-1938)

Thomas Wolfe left his birthplace, Asheville, North Carolina, at fifteen to enroll at the University of North Carolina at Chapel Hill, where he edited the college magazine and wrote a one-act play. He received his M.A. degree from Harvard and later taught English at New York University. In 1930 he received a Guggenheim Fellowship.

Although Wolfe was a prolific writer, he published only two novels, Look Homeward Angel, and Of Time and the River, before his untimely death in 1938. You Can't Go Home Again and The Web and the Rock were published posthumously.

In all his novels Wolfe himself is the central character, thinly disguised, first as Eugene Gant and later as George Webber.

In this excerpt from The Hills Beyond, a collection of Wolfe's shorter writings, Eugene Gant returns to his boyhood home to recapture his childhood, only to find that the lost boy has gone forever.

\section{The Brother}

"This is King's Highway," the man said.

And then Eugene looked and saw that it was just a street. There were some big new buildings, a large hotel, some restaurants and "bar-grill" places of the modern kind, the livid 
monotone of neon lights, the ceaseless traffic of motor carsall this was new, but it was just a street. And he knew that it had always been just a street, and nothing more-but somehow-well, he stood there looking at it, wondering what else he had expected to find.

The man kept looking at him with inquiry in his eyes, and Eugene asked him if the Fair had not been out this way.

"Sure, the Fair was out beyond here," the man said. "Out where the park is now. But this street you're looking fordon't you remember the name of it or nothing?" the man said.

Eugene said he thought the name of the street was Edgemont, but that he wasn't sure. Anyhow it was something like that. And he said the house was on the corner of that street and of another street.

The man said" "What was that other street?"

Eugene said he did not know, but that King's Highway was a block or so away, and that an interurban line ran past about a half a block from where he once had lived.

"What line was this?" the man said, and stared at him.

"The interurban line," Eugene said.

Then the man stared at him again, and finally, "I don't know no interurban line," he said.

Eugene said it was a line that ran behind some houses, and that there were board fences there and grass beside the tracks. But somehow he could not say that it was summer in those days and that you could smell the ties, a wooden, tarry smell, and feel a kind of absence in the afternoon after the car had gone. He only said the interurban line was back behind somewhere between the backyards of some houses and some old board fences, and that King's Highway was a block or two away.

He did not say that King's Highway had not been a street in those days but a kind of road that wound from magic out of some dim and haunted land, and that along the way it had got mixed in with Tom the Piper's son, with hot cross buns, with all the light that came and went, and with coming down through Indiana in the morning, and the smell of engine 
smoke, the Union Station, and most of all with voices lost and far and long ago that said "King's Highway."

He did not say these things about King's Highway because he looked about him and saw what King's Highway was. All he could say was that the street was near King's Highway, and was on the corner, and that the interurban trolley line was close to there. He said it was a stone house, and that there were stone steps before it, and a strip of grass. He said he thought the house had had a turret at one corner, he could not be sure.

The man looked at him again, and said, "This is King's Highway, but I never heard of any street like that."

Eugene left him then, and went on till he found the place. And so at last he turned into the street, finding the place where the two corners met, the huddled block, the turret, and the steps, and paused a moment, looking back, as if the street were Time.

For a moment he stood there, waiting-for a word, and for a door to open, for the child to come. He waited, but no words were spoken; no one came.

Yet all of it was just as it had always been, except that the steps were lower, the porch less high, the strip of grass less wide, than he had thought. All the rest of it was as he had known it would be. A graystone front, three-storied, with a slant slate roof, the side red brick and windowed, still with the old arched entrance in the center for the doctor's use.

There was a tree in front, and a lamp post; and behind and to the side, more trees than he had known there would be. And all the slatey turret gables, all the slatey window gables, going into points, and the two arched windows, in strong stone, in the front room.

It was all so strong, so solid, and so ugly-and all so enduring and so good, the way he had remembered it, except he did not smell the tar, the hot and caulky dryness of the old cracked ties, the boards of backyard fences and the coarse and sultry grass, and absence in the afternoon when the street car had gone, and the twins, sharp-visaged in their sailor suits, pumping with furious shrillness on tricycles up and down before the 
house, and the feel of the hot afternoon, and the sense that everyone was absent at the Fair.

Except for this, it all was just the same; except for this and for King's Highway, which was now a street; except for this, and for the child that did not come.

It was a hot day. Darkness had come. The heat rose up and hung and sweltered like a sodden blanket in St. Louis. It was wet heat, and one knew that there would be no relief or coolness in the night. And when one tried to think of the time when the heat would go away, one said: "It cannot last. It's bound to go away," as we always say it in America. But one did not believe it when he said it. The heat soaked down and men sweltered in it: the faces of the people were pale and greasy with the heat. And in their faces was a patient wretchedness, and one felt the kind of desolation that one feels at the end of a hot day in a great city in America-when one's home is far away, across the continent, and he thinks of all that distance, all that heat, and feels, "Oh God! but it's a big country!"

And he feels nothing but absence, absence, and the desolation of America, the loneliness and sadness of the high, hot skies, and evening coming on across the Middle West, across the sweltering and heat-sunken land, across all the lonely little towns, the farms, the fields, the oven swelter of Ohio, Kansas, Iowa, and Indiana at the close of day, and voices, casual in the heat, voices at the little stations, quiet, casual, somehow faded into that enormous vacancy and weariness of heat, of space, and of the immense, the sorrowful, the most high and awful skies.

Then he hears the engine and the wheel again, the wailing whistle and the bell, the sound of shifting in the sweltering yard, and walks the street, and walks the street, beneath the clusters of hard lights, and by the people with sagged faces, and is drowned in desolation and in no belief.

He feels the way one feels when one comes back, and knows that he should not have come, and when he sees that, after all, King's Highway is-a street; and St. Louis-the enchanted name-a big, hot, common town upon the river, 
sweltering in wet, dreary heat, and not quite South, and nothing else enough to make it better.

It had not been like this before. He could remember how it would get hot, and how good the heat was, and how he would lie out in the backyard on an airing mattress, and how the mattress would get hot and dry and smell like a hot mattress full of sun, and how the sun would make him want to sleep, and how, sometimes, he would go down into the basement to feel coolness, and how the cellar smelled as cellars always smell-a cool, stale smell, the smell of cobwebs and of grimy bottles. And he could remember, when you opened the door upstairs, the smell of the cellar would come up to youcool, musty, stale and dank and dark - and how the thought of the dark cellar always filled him with a kind of numb excitement, a kind of visceral expectancy.

He could remember how it got hot in the afternoons, and how he would feel a sense of absence and vague sadness in the afternoons, when everyone had gone away. The house would seem so lonely, and sometimes he would sit inside, on the second step of the hall stairs, and listen to the sound of silence and of absence in the afternoon. He could smell the oil upon the floor and on the stairs, and see the sliding doors with their brown varnish and the beady chains across the door, and thrust his hands among the beady chains, and gather them together in his arms, and let them clash, and swish with light beady swishings all around him. He could feel darkness, absence, varnished darkness, and stained light within the house, through the stained glass of the window on the stairs, through the small stained glasses by the door, stained light and absence, silence and the smell of floor oil and vague sadness in the house on a hot mid-afternoon. And all these things themselves would have a kind of life: would seem to wait attentively, to be most living and most still.

He would sit there and listen. He could hear the girl next door practice her piano lessons in the afternoon, and hear the street car coming by between the backyard fences, half a block away, and smell the dry and sultry smell of backyard fences, 
the smell of coarse hot grasses by the car tracks in the afternoon, the smell of tar, of dry caulked ties, the smell of bright worn flanges, and feel the loneliness of backyards in the afternoon and the sense of absence when the car was gone.

Then he would long for evening and return, the slant of light, and feet along the street, the sharp-faced twins in sailor suits upon their tricycles, the smell of supper and the sound of voices in the house again, and Grover coming from the Fair.

That is how it was when he came into the street, and found the place where the two corners met, and turned at last to see if Time was there. He passed the house; some lights were burning, the door was open, and a woman sat upon the porch. And presently he turned, came back, and stopped before the house again. The corner light fell blank upon the house. He stood looking at it, and put his foot upon the step.

Then he said to the woman who was sitting on the porch: "This house- excuse me-but could you tell me, please, who lives here in this house?"

He knew his words were strange and hollow, and he had not said what he wished to say. She stared at him a moment, puzzled.

Then she said: "I live here. Who are you looking for?"

He said, "Why, I am looking for-"

And then he stopped, because he knew he could not tell her what it was that he was looking for.

"There used to be a house- - he said.

The woman was now staring at him hard.

He said, "I think I used to live here."

She said nothing.

In a moment he continued, "I used to live here in this house," he said, "when I was a little boy."

She was silent, looking at him, then she said: "Oh. Are you sure this was the house? Do you remember the address?"

"I have forgotten the address," he said, "but it was Edgemont Street, and it was on the corner. And I know this is the house." 
"This isn't Edgemont Street," the woman said. "The name is Bates."

"Well, then, they changed the name of the street," he said, "but this is the same house. It hasn't changed."

She was silent a moment, then she nodded: "Yes. They did change the name of the street. I remember when I was a child they called it something else," she said. "But that was a long time ago. When was it that you lived here?"

"In 1904."

Again she was silent, looking at him.. Then presently: "Oh. That was the year of the Fair. You were here then?"

"Yes." He now spoke rapidly, with more confidence. "My mother had the house, and we were here for seven months. And the house belonged to Dr. Packer," he went on. "We rented it from him."

"Yes," the woman said, and nodded, "this was Dr. Packer's house. He's dead now, he's been dead for many years. But this was the Packer house, all right."

"That entrance on the side," he said, "where the steps go up, that was for Dr. Packer's patients. That was the entrance to his office."

"Oh," the woman said, "I didn't know that. I've often wondered what it was. I didn't know what it was for."

"And this big room in front here," he continued, "that was the office. And there were sliding doors, and next to it, a kind of alcove for his patients-"

"Yes, the alcove is still there, only all of it has been made into one room now-and I never knew just what the alcove was for."

"And there were sliding doors on this side, too, that opened on the hall-and a stairway going up upon this side. And halfway up the stairway, at the landing, a little window of colored glass-and across the sliding doors here in the hall, a kind of curtain made of strings of beads."

She nodded, smiling. "Yes, it's just the same-we still have the sliding doors and the stained glass window on the stairs. There's no bead curtain any more," she said, "but I remember 
when people had them. I know what you mean."

"When we were here," he said, "we used the doctor's office for a parlor-except later on-the last month or two-and then we used it for a bedroom."

"It is a bedroom now," she said. "I run the house-I rent rooms-all of the rooms upstairs are rented-but I have two brothers and they sleep in this front room."

Both of them were silent for a moment, then Eugene said, "My brother stayed there too."

"In the front room?" the woman said.

He answered, "Yes."

She paused, then said: "Won't you come in? I don't believe it's changed much. Would you like to see?"

He thanked her and said he would, and he went up the steps. She opened the screen door to let him in.

Inside it was just the same-the stairs, the hallway, the sliding doors, the window of stained glass upon the stairs. And all of it was just the same, except for absence, the stained light of absence in the afternoon, and the child who once had sat there, waiting on the stairs.

It was all the same except that as a child he had sat there feeling things were Somewhere-and now he knew. He had sat there feeling that a vast and sultry river was somewhere-and now he knew! He had sat there wondering what King's Highway was, where it began, and where it ended-now he knew! He had sat there haunted by the magic word "downtown"now he knew! - and by the street car, after it had gone-and by all things that came and went and came again, like the cloud shadows passing in a wood, that never could be captured.

And he felt that if he could only sit there on the stairs once more, in solitude and absence in the afternoon, he would be able to get it back again. Then he would be able to remember all that he had seen and been-the brief sum of himself, the universe of his four years, with all the light of Time upon itthat universe which was so short to measure, and yet so far, so endless, to remember. Then would he be able to see his own small face again, pooled in the dark mirror of the hall, and peer 
once more into the grave eyes of the child that he had been, and discover there in his quiet three-years' self the lone integrity of "I," knowing: "Here is the House, and here House listening; here is Absence, Absence in the afternoon; and here in this House, this Absence, is my core, my kernel-here am I!"

But as he thought it, he knew that even if he could sit here alone and get it back again, it would be gone as soon as seized, just as it had been then-first coming like the vast and drowsy rumors of the distant and enchanted Fair, then fading like cloud shadows on a hill, going like faces in a dream-coming, going, coming, possessed and held but never captured, like lost voices in the mountains long ago-and like the dark eyes and quiet face of the dark, lost boy, his brother, who, in the mysterious rhythms of his life and work, used to come into this house, then go, and then return again.

The woman took Eugene back into the house and through the hall. He told her of the pantry, told where it was and pointed to the place, but now it was no longer there. And he told her of the backyard, and the old board fence around the yard. But the old board fence was gone. And he told her of the carriage house, and told her it was painted red. But now there was a small garage. And the backyard was still there, but smaller than he thought, and now there was a tree.

"I did not know there was a tree," he said. "I do not remember any tree."

"Perhaps it was not there," she said. "A tree could grow in thirty years." And then they came back through the house again and paused at the sliding doors.

"And could I see this room?" he said.

She slid the doors back. They slid open smoothly, with a rolling heaviness, as they used to do. And then he saw the room again. It was the same. There was a window at the side, the two arched windows at the front, the alcove and the sliding doors, the fireplace with the tiles of mottled green, the mantel of dark mission wood, the mantel posts, a dresser and a bed, just where the dresser and the bed had been so long ago. 
"Is this the room?" the woman said. "It hadn't changed?" He told her that it was the same.

"And your brother slept here where my brothers sleep?"

"This is his room," he said.

They were silent. He turned to go, and said, "Well, thank you. I appreciate your showing me."

She said that she was glad and that it was no trouble, "and when you see your family, you can tell them that you saw the house," she said. "My name is Mrs. Bell. You can tell your mother that a Mrs. Bell has the house now. And when you see your brother, you can tell him that you saw the room he slept in, and that you found it just the same."

He told her then that his brother was dead.

The woman was silent for a moment. Then she looked at him and said: "He died here, didn't he? In this room?"

He told that it was so.

"Well, then," she said, "I knew it. I don't know how. But when you told me he was here, I knew it."

He said nothing. In a moment the woman said, "What did he die of?"

"Typhoid."

She looked shocked and troubled, and said involuntarily, "My two brothers-"

"That was a long time ago," he said. "I don't think you need to worry now."

"Oh, I wasn't thinking about that," she said. "It was just hearing that a little boy-your brother-was-was in this room that my two brothers sleep in now-"

"Well, maybe I shouldn't have told you then. But he was a good boy-and if you'd known him you wouldn't mind."

She said nothing, and he added quickly: "Besides, hedidn't stay here long. This wasn't really his room-but the night he came back with my sister he was so sick-they didn't move him."

"Oh," the woman said, "I see." And then: "Are you going to tell your mother you were here?"

"I don't think so." 
"I-I wonder how she feels about this room."

"I don't know. She never speaks of it."

"Oh....How old was he?"

"He was twelve."

"You must have been pretty young yourself."

"I was not quite four."

"And-you just wanted to see the room, didn't you? That's why you came back."

"Yes."

"Well-"indefinitely - I guess you've seen it now."

"Yes, thank you."

"I guess you don't remember much about him, do you? I shouldn't think you would."

"No, not much."

The years dropped off like fallen leaves: the face came back again-the soft dark oval, the dark eyes, the soft brown berry on the neck, the raven hair, all bending down, approachingthe whole appearing to him ghost-wise, intent and instant.

"Now say it_Grover!"

"Gova."

"No-not Gova-Grover!...Say it!"

"Gova."

"Ah-h-you didn't say it. You said Gova. Grover-now say it!"

"Gova."

"Look, I tell you what I'll do if you say it right. Would you like to go down to King's Highway? Would you like Grover to set you up? All right, then. If you say Grover and say it right, I'll take you to King's Highway and set you up to ice cream. Now say it right-Grover!"

"Gova."

"Ah-h, you-u. Old Tongue-Tie, that's what you are....Well, come on, then I'll set you up anyway."

It all came back, and faded, and was lost again. Eugene turned to go, and thanked the woman and said good-bye.

"Well, then, good-bye," the woman said, and they shook 
hands. "I'm glad if I could show you. I'm glad if-" She did not finish, and at length she said: "Well, then, that was a long time ago. You'll find everything changed now, I guess. It's all built up around here now-and way out beyond here, out beyond where the Fair Grounds used to be. I guess you'll find it changed."

They had nothing more to say. They just stood there for a moment on the steps, and then shook hands once more.

"Well, good-bye."

And again he was in the street, and found the place where the corners met, and for the last time turned to see where Time had gone.

And he knew he would never come again, and that lost magic would not come again. Lost now was all of it - the street, the heat, King's Highway, and Tom the Piper's son, all mixed in with the vast and drowsy murmur of the Fair, and with the sense of absence in the afternoon, and the house that waited, and the child that dreamed. And out of the enchanted wood, that thicket of man's memory, Eugene knew that the dark eye and the quiet face of his friend and brother-poor child, life's stranger, and life's exile, lost like all of us, a cipher in blind mazes, long ago-the lost boy was gone forever, and would not return. 


\section{The Brother}

1. Eugene seems to have trouble communicating with the man from whom he asks directions. Why do you think this is so?

2. What sensory imagery (smell, touch, sound, etc.) does the author use to capture Eugene's childhood memories?

3. When Eugene found the house he was looking for, what expectations did he probably have? Were his expectations fulfilled? Why or why not?

4. What clues to Eugene's past can be found through his return? 
JAMES R. STOKELY, JR. (1913-1977)

James Stokely was born in Newport, Tennessee, and graduated from the University of Tennessee at Knoxville. He and his wife Wilma Dykeman, a noted writer of both fiction and non-fiction, co-authored a number of books and articles. Their book Neither Black nor White received a Sidney Hillman Foundation award.

His poem "Molly Mooneyham" is about a mountain woman who has lived long enough to see the old mountain life transformed into the jet age. We come to admire her perspective, as she delivers a monologue of reminiscences.

\section{Molly Mooneyham}

It's been a hard life, Lord knows, But I've craved every minute of it. I only had a snatch of schooling And a sniff of this world's gold But I wrestled with thirteen sisters and brothers And now a whole slew of my own blood Has fetched younguns of their own We're a sight when we all get together! We tell tales that were never told. 
I don't go for these new-fangled washing motors;

I'll stick to my black pot and battling stick

Till I die. They work out the dirt.

Twice a week I've had lines full of shirts and pants

I made myself, and the wind stirring beneath the sun

Was the best drying machine in the world.

$I^{\prime} d$ see rainbows in all the colored aprons

And the overalls were wind-filled balloons

Stretching from the clutch of our wire

Toward Rube McBee's pigpen over the hill.

Lord God, I was born wagging my tongue!

I never needed a swig of the devil's sauce

To loosen the joints and juices of my old frame.

There's nothing like big chunks of green timber

To make the pot boil, and I always rinse three times

After beating the batch on the white oak log.

Is there any smell better than fresh clean clothes

Packed in a hand-woven basket

Or bread rising from one's own oven?

Beats a wild plum thicket in April

Or burning leaves in November.

What else goes on around these parts?

Plenty for them that has the rise-up-and-reach.

After the rheumatiz and the high blood struck me

I still work my garden in the cool of dawn;

I kneel to scratch the dark rocky loam

Down in the corn and sweet 'tater patch

With 'Tucky Wonders running all over the place

And moon-eyed melons peeking out from the vines.

I've sent everyone of my younguns

Through Cataloochee High, and four to college.

Lord God, I never had one yet to balk!

Three of 'em are now teaching in Sky City

And the youngest is training down at Cape Kennedy.

$\mathrm{He}^{\prime} \mathrm{s}$ got a bead on the stars, digging in deep,

A-rooting where the acorns are, I vow. 
What a living pleasure it is to know

Your own flesh is climbing the big bean stalk!

I'm afeared of gas and power-driven gadgets;

I'll stick to my single-bit axe and crosscut saw

Till the Old Master tells me it's time.

I like to have my feet on Catalooch earth

And my eyes on the hinges of heaven.

I love to tell the old, old story;

I sometimes slip down inside myself a long spell

Brooding over the miseries of this old world

Then rise up to shout in open meeting

When they start singing "Beulah Land,"

"Amazing Grace" or "In the Cross"

Be my glory ever!

Rest beyond the river!

Glory! Glory! Glory! Glory!

We need grief in our hearts for each other.

Son, are you saved? In Jesus-name?

Are you giving the Big No to hell?

There's nobody takes after life more than I do;

I like to cram hickory sticks in my cook stove

And brown up a batch of bisquits

To mix with homemade sausage and gravy, And I never set a meal, in the fiercest snow, Without a dish of Limbertwig or Sourjohn jelly. I aim to get up at sun's first-glance

When roosters are crowing and clawing the ground,

Put in a full gee-haw at being a woman,

Then sink back to the old feathertick at black dark

When pullets have flown to the highest limb.

Sometimes I dream of my man, Mitch Mooneyham,

And how he ran the wrong way

When the red oak was falling

But I'm raring to go when the fire-ball peeps up

And lay hold of a new-born situation. 
I canned over seven hundred jars last summer, Beans, beets, squash, 'maters, blackberries, corn, And dried twenty bushels of Pippins and Winesaps.

I've never taken a pill in all my life

And I've lasted eighty-three year

Come Saturday week.

Lord, what I wouldn't give for another round!

I'd like another chance to do my dance.

Say you live near Smoky Town? Well, now, I've never seen the sights there,

Don't know about these here plays and op'rys,

But I've heard the meadow lark sing

And cocked an ear or two, I vow,

When guineas cackled in the hillside clover

And old Catalooch Creek chuckled to itself

As it wandered down to meet the big river.

I've never viewed a picture museum

But I haven't missed a sunset yet

Nor a thunderstorm either, for that matter.

Many's the time I've laid up at noon

After churning the cream to a buttery pulp

And watched a fern unfold by the springhouse door.

Lord! Lord! It's been a hello-come to!

I never had a cookie jar of greenbacks to hoard

And I never haunted the cage of a bank in Smoky Town

But I claimed gold for my own in daffodils,

Dandelions, muscadines, peaches and pears,

Not to mention pheasants and bushy-tailed squirrels-

And, say, did you ever spy forsythia in full bloom

Or sip clear cold water out of a speckled gourd?

I never had a doctor to catch my babies;

I just shared with Granny Haun and my man

The miracle of creation.

He died a month before Timothy was born.

I've been forty years a widow

But in each sparkling eye was his shadow. 
I loved to watch their crinkly little faces

Tune up and squall-Lord be! -

And then I liked it when they took my breast

And grew quiet, like something far and lost

And never been on this earth before.

\section{Molly Mooneyham}

1 Why wasn't Molly Mooneyham interested in a new-fangled washing machine? What would she have missed if she had had one?

2. Discuss the following lines: "I only had a snatch of schooling and a sniff of this world's gold." "He's got a bead on the stars, digging in deep, a-rooting where the acorns are, I vow." "I'd like another chance to do my dance." What do they tell you about Molly?

3. What is Molly Mooneyham's attitude toward picture museums, banks, and doctors? Is her world limited? 
JAMES AGEE (1909-1955)

Knoxville native James Agee turned out a substantial body of work in his forty-six years. While at Harvard, he published his first book, a poetry collection entitled Permit Me Voyage, which was selected by the Yale Series for Younger Poets in 1934.

After college, Agee worked for Time and Nation. As a staff writer for Fortune Magazine, he spent a summer living with a family of Alabama sharecroppers, an experience that resulted in his book Let Us Now Praise Famous Men. Agee, also a film critic and noted screen writer, wrote the scripts for Face-to-Face and The African Queen.

The next selection is from his Pulitzer Prize-winning novel, A Death in the Family, published after his death in 1957. It is a moving, poignant story of a young boy's visit to his great-greatgrandmother.

\section{From $A$ Death in the Family}

After dinner the babies and all the children except Rufus were laid out on the beds to take their naps, and his mother thought he ought to lie down too, but his father said no, why did he need to, so he was allowed to stay up. He stayed out on the porch with the men. They were so full up and sleepy they 
hardly even tried to talk, and he was so full up and sleepy that he could hardly see or hear, but half dozing between his father's knees in the thin shade, trying to keep his eyes open, he could just hear the mild, lazy rumbling of their voices, and the more talkative voices of the women back in the kitchen, talking more easily, but keeping their voices low, not to wake thechildren, and the rattling of the dishes they were doing, and now and then their walking here or there along the floor; and mused with half-closed eyes which went in and out of focus with sleepiness, upon the slow twinkling of the millions of heavy leaves on the trees and the slow flashing of the blades of corn, and nearer at hand, the hens dabbing in the pocked dirt yard and the ragged edge of the porch floor, and everything hung dreaming in a shining silver haze, and a long, low hill of blue silver shut off everything against a blue-white sky, and he leaned back against his father's chest and he could hear his heart pumping and his stomach growling and he could feel the hard knees against his sides, and the next thing he knew his eyes opened and he was looking up into his mother's face and he was lying on a bed and she was saying it was time to wake up because they were going on a call and see his great-greatgrandmother and she would most specially want to see him because he was her oldest great-great-grandchild. And he and his father and mother and Catherine got in the front seat and his Granpa Follet and Aunt Jessie and her baby and Jim Wilson and Ettie Lou and Aunt Sadie and her baby got in the back seat and Uncle Ralph stood on the running board because he was sure he could remember the way and that was all there was room for, and they started off very carefully down the lane, so nobody would be jolted, and even before they got out to the road his mother asked his father to stop a minute, and she insisted on taking Ettie Lou with them in front, to make a little more room in the back, and after she insisted for a while, they gave in, and then they all got started again, and his father guided the auto so very carefully across the deep ruts into the road, the other way from LaFollette as Ralph told him to ("Yeah, I know," his father said, "I remember that much 
anyhow."), that they were hardly joggled at all, and his mother commented on how very nicely and carefully his father always drove when he didn't just forget and go too fast, and his father blushed, and after a few minutes his mother began to look uneasy, as if she had to go to the bathroom but didn't want to say anything about it, and after a few minutes more she said, "Jay, I'm awfully sorry but now I really think you are forgetting."

"Forgetting what?" he said.

"I mean a little too fast, dear," she said.

"Good road along here," he said. "Got to make time while the road's good." He slowed down a little. "Way I remember it," he said, "there's some stretches you can't hardly ever get a mule through, we' re coming to, ain't they, Ralph?"

"Oh mercy," his mother said.

"We are just raggin you," he said. "They' re not all that bad. But all the same we better make time while we can." And he sped up a little.

After another two or three miles Uncle Ralph said, "Now around this bend you run through a branch and you turn up sharp to the right," and they ran through the branch and turned into a sandy woods road and his father went a little slower and a cool breeze flowed through them and his mother said how lovely this shade was after that terrible hot sun, wasn't it, and all the older people murmured that it sure was, and almost immediately they broke out of the woods and ran through two miles of burned country with stumps and sometimes whole tree trunks sticking up out of it sharp and cruel, and blackberry and honeysuckle all over the place, and a hill and its shadow ahead. And when they came within the shadow of the hill, Uncle Ralph said in a low voice, "Now you get to the hill, start along the base of it to your left till you see your second right and then you take that," but when they got there, there was only the road to the left and none to the right and his father took it and nobody said anything, and after a minute Uncle Ralph said, "Reckon they wasn't much too choose from there, was they?" and laughed unhappily.

"That's right," his father said, and smiled. 
"Reckon my memory ain't so sharp as I bragged," Ralph said.

"You're doin fine," his father said, and his mother said so too.

"I could a swore they was a road both ways there," Ralph said, "but it was nigh on twenty years since I was out here." Why for goodness sake, his mother said, then she certainly thought he had a wonderful memory.

"How long since you were here, Jay?" He did not say anything. "Jay?"

"I'm a-studyin it," he said.

"There's your turn," Ralph said suddenly, and they had to back the auto to turn into it.

They began a long, slow, winding climb, and Rufus half heard and scarcely understood their disjointed talking. His father had not been there in nearly thirteen years; the last time was just before he came to Knoxville. He was always her favorite, Ralph said. Yes, his grandfather said, he reckoned that was a fact, she always seemed to take a shine to Jay. His father said quietly that he always did take a shine to her. It turned out he was the last of those in the auto who had seen her. They asked how she was, as if it had been within a month or two. He said she was failing lots of ways, specially getting around, her rheumatism was pretty bad, but in the mind she was bright as a dollar, course that wasn't saying how they might find her by now, poor old soul; no use saying. Nope, Uncle Ralph said, that was a fact; time sure did fly, didn't it; seemed like before you knew it, this year was last year. She had never yet seen Jay's children, or Ralph's, or Jessie's or Sadie's, it was sure going to be a treat for her. A treat and a surprise. Yes it sure would be that, his father said, always supposing she could still recognize them. Mightn't she even have died? his mother wanted to know. Oh no, all the Follets said they'd have heard for sure if she'd died. Matter of fact they had heard she had failed a good bit. Sometimes her memory slipped up and she got confused, poor old soul. His mother said well she should think so, poor old lady. She asked, care- 
fully, if she was taken good care of. Oh, yes, they said. That she was. Sadie's practically giving her life to her. That was Grandpa Follet's oldest sister and young Sadie was named for her. Lived right with her tending to her wants, day and night. Well, isn't that just wonderful, his mother said. Wasn't anybody else could do it, they agreed with each other. All married and gone, and she wouldn't come live with any of them, they all offered, over and over, but she wouldn't leave her home. I raised my family here, she said, I lived here all my life from fourteen years on and I aim to die here, that must be a good thirty-five, most, a good near forty year ago, Grampaw died. Goodness sake, his mother said, and she was an old old woman then! His father said soberly, "She's a hundred and three years old. Hundred and three or hundred and four. She never could remember for sure which. But she knows she wasn't born later than eighteen-twelve. And she always reckoned it might of been eighteen-eleven."

"Great heavens, Jay! Do you mean that?" He just nodded, and kept his eyes on the road. "Just imagine that, Rufus," she said. "Just think of that!"

"She's an old, old lady," his father said gravely; and Ralph gravely and proudly concurred.

"The things she must have seen!" Mary said, quietly. "Indians. Wild animals." Jay laughed. "I mean man-eaters, Jay. Bears, and wildcats-terrible things."

"There were cats back in these mountains, Mary-we called em painters, that's the same as a panther-they were around here still when I was a boy. And there is still bear, they claim."

"Gracious Jay, did you ever see one? A panther?"

"Saw one'd been shot."

"Goodness," Mary said.

"A mean-looking varmint."

"I know," she said. "I mean, I bet he was. I just can't get over-why she's almost as old as the country, Jay."

"Oh, no," he laughed. "Ain't nobody that old. Why I read somewhere, that just these mountains here are the oldest..."

"Dear, I meant the nation," she said. "The United States, I 
mean. Why let me see, why it was hardly as old as I am when she was born." They all calculated for a moment. "Not even as old," she said triumphantly.

"By golly," his father said. "I never thought of it like that." He shook his head. "By golly," he said, "that's a fact."

"Abraham Lincoln was just two years old," she murmured. "Maybe three," she said grudgingly. "Just try to imagine that, Rufus," she said after a moment. "Over a hundred years." But she could see that he couldn't comprehend it. "You know what she is?" she said, "she's Granpa Follet's grandmother!"

"That's a fact, Rufus," his grandfather said from the back seat, and Rufus looked around, able to believe it but not to imagine it, and the old man smiled and winked. "Woulda never believed you'd hear me call nobody 'Granmaw,' now would you?"

"No sir," Rufus said.

"Well, yer goana," his grandfather said, "quick's I see her."

Ralph was beginning to mutter and to look worried and finally his brother said, "What's eaten ye, Ralph? Lost the way?" And Ralph said he didn't know for sure as he had lost it exactly, no, he wouldn't swear to that yet, but by golly he was damned if he was sure this was hit anymore, all the same.

"Oh dear, Ralph, how too bad," Mary said, "but don't you mind. Maybe we'll find it. I mean maybe soon you'll recognize landmarks and set us all straight again."

But his father, looking dark and painfully patient, just slowed the auto down and then came to a stop in a shady place. "Maybe we better figure it out right now," he said.

"Nothin round hyer I know," Ralph said, miserably. "What I mean, maybe we ought to start back while we still know the way back. Try it another Sunday."

"Oh, Jay."

"I hate to but we got to get back in town tonight, don't forget. We could try it another Sunday. Make an early start." But the upshot of it was that they decided to keep on ahead awhile, anyway. They descended into a long, narrow valley through the woods of which they could only occasionally see the dark 
ridges and the road kept bearing in a direction Ralph was almost sure was wrong, and they found a cabin, barely even cut out of the woods, they commented later, hardly even a corn patch, big as an ordinary barnyard; but the people there, very glum and watchful, said they had never even heard of her; and after a long while the valley opened outa littleand Ralph began to think that perhaps he recognized it, only it sure didn't look like itself if it was it, and all of a sudden a curve opened into half-forested meadow and there were glimpses of a gray house through swinging vistas of saplings and Ralph said, "By golly," and again, "By golly, that is hit. That's hit all right. Only we come on it from behind!" And his father began to be sure too, and the house grew larger, and they swung around where they could see the front of it, and his father and his Uncle Ralph and his Grandfather all said, "Why sure enough," and sure enough it was: and, "There she is," and there she was: it was a great, square-logged gray cabin closed by a breezeway, with a frame second floor, and an enormous oak plunging from the packed dirt in front of it, and a great iron ring, the rim of a wagon wheel, hung by a chain from a branch of the oak which had drunk the chains into itself, and in the shade of the oak, which was as big as the whole corn patch they had seen, an old woman was standing up from a kitchen chair as they swung slowly in onto the dirt and under the edge of the shade, and another old woman continued to sit very still in her chair.

The younger of the two old women was Great Aunt Sadie, and she knew them the minute she laid eyes on them and came right on up to the side of the auto before they could even get out. "Lord God," she said in a low, hard voice, and she put her hands on the edge of the auto and just looked from one to the other of them. Her hands were long and narrow and as big as a man's and every knuckle was swollen and split. She had hard black eyes, and there was a dim purple splash all over the left side of her face. She looked at them so sharply and silently from one to another that Rufus thought she must be mad at them, and then she began to shake her head back and forth. "Lord God," she said again. "Howdy, John Henry," she said. 
"Howdy, Sadie," his grandfather said.

"Howdy, Aunt Sadie," his father and his Aunt Sadie said.

"Howdy, Jay," she said, looking sternly at his father, "howdy, Ralph," and she looked sternly at Ralph. "Reckon you must be Jess, and yore Sadie. Howdy, Sadie."

"This is Mary, Aunt Sadie," his father said. "Mary, this is Aunt Sadie."

"I'm proud to know you," the old woman said, looking very hard at his mother. "I figured it must be you," she said, just as his mother said, "I'm awfully glad to know you too." "And this is Rufus and Catherine and Ralph's Jim-Wilson and Ettie Lou and Jessie's Charlie after his daddy and Sadie's Jessie after her Granma and her Aunt Jessie," his father said.

"Well, Lord God," the old woman said. "Well, file on out."

"How's Granmaw?" his father asked, in a low voice, without moving yet to get out.

"Good as we got any right to expect," she said, "but don't feel put out if she don't know none-a-yews. She mought and she mought not. Half the time she don't even know me."

Ralph shook his head and clucked his tongue. "Pore old soul," he said, looking at the ground. His father let out a slow breath, puffing his cheeks.

"So if I was you-all I'd come up on her kind of easy," the old woman said. "Bin a coon's age since she seen so many folks at onct. Me either. Mought skeer her if ye all come a whoopin up at her in a flock."

"Sure," his father said.

"Ayy," his mother whispered.

His father turned and looked back. "Whyn't you go see her the first, Paw?" he said very low. "Yore the eldest."

"Tain't me she wants to see," Grandfather Follet said, "Hit's the younguns ud tickle her most."

"Reckon that's the truth, if she can take notice," the old woman said. "She shore like to cracked her heels when she heared yore boy was born," she said to Jay, "Mary or no Mary. Proud as Lucifer. Cause that was the first," she told Mary.

"Yes, I know," Mary said. "Fifth generation, that made." 
"Did you get her postcard, Jay?"

"What postcard?"

"Why no," Mary said.

"She tole me what to write on one a them postcards and put hit in the mail to both a yews so I done it. Didn't ye never get it?"

Jay shook his head. "First I ever heard tell of it," he said.

"Well I shore done give hit to the mail. Ought to remember. Cause I went all the way into Polly to buy it and all the way in again to put it in the mail."

"We never did get it," Jay said.

"What street did you send it, Aunt Sadie?" Mary asked. "Because we moved not long be..."

"Never sent it to no street," the old woman said. "Never knowed I needed to, Jay working for the post office."

"Why, I quit working for the post office a long time back, Aunt Sadie. Even before that."

"Well I reckon that's how come then. Cause I just sent hit to 'Post Office, Cristobal, Canal Zone, Panama,' and I spelt hit right, too. C-r-i..."

"Oh," Mary said.

"Aw," Jay said. "Why, Aunt Sadie, I thought you'd a known. We been living in Knoxvul since pert near two years before Rufus was born."

She looked at him keenly and angrily, raising her hands slowly from the edge of the auto, and brought them down so hard that Rufus jumped. Then she nodded, several times, and still she did not say anything. At last she spoke, coldly, "Well, they might as well just put me out to grass," she said. "Lay me down and give me both barls threw the head."

"Why, Aunt Sadie," Mary said gently, but nobody paid any attention.

After a moment the old woman went on solemnly, staring hard into Jay's eyes: "I knowed that like I know my own name and it plumb slipped my mind."

"Oh what a shame," Mary said sympathetically.

"Hit ain't shame I feel," the old woman said, "hit's sick in 
the stummick."

"Oh I didn't m..."

"Right hyer!" and she slapped her hand hard against her stomach and laid her hand back on the edge of the auto. "If I git like that too," she said to Jay, "then who's agonna look out fer her?"

"Aw, tain't so bad, Aunt Sadie," Jay said. "Everybody slips up nown then. Do it myself an I ain't half yer age. And you just ought see Mary."

"Gracious, yes," Mary said. "I'm just a perfect scatterbrain."

The old woman looked briefly at Mary and then looked back at Jay. "Hit ain't the only time," she said, "not by a long chalk. Twarn't three days ago I..." she stopped. "Takin on about yer troubles ain't never holp nobody," she said. "You just set hyer a minute."

She turned and walked over to the older woman and leaned deep over against her ear and said quite loudly, but not quite shouting, "Granmaw, ye got company." And they watched the old woman's pale eyes, which had been on them all this time in the light shadow of the sunbonnet, not changing, rarely ever blinking, to see whether they would change now, and they did not change at all, she didn't even move her head or her mouth. "Ye hear me, Granmaw?" The old woman opened and shut her sunken mouth, but not as if she were saying anything. "Hit's Jay and his wife and younguns, come up from Knoxvul to see you," she called, and they saw the hands crawl in her lap and the face turned towards the younger woman and they could hear a thin, dry crackling, no words.

"She can't talk any more," Jay said, almost in a whisper.

"Oh no," Mary said.

But Sadie turned to them and her hard eyes were bright. "She knows ye," she said quietly. "Come on over." And they climbed slowly and shyly out onto the swept ground. "I'll tell her about the rest a yuns in a minute," Sadie said.

"Don't want to mix her up," Ralph explained, and they all nodded.

It seemed to Rufus like a long walk over to the old woman 
because they were all moving so carefully and shyly; it was almost like church. "Don't holler," Aunt Sadie was advising his parents, "hit only skeers her. Just talk loud and plain right up next her ear."

"I know," his mother said. "My mother is very deaf, too."

"Yeah," his father said. And he bent down close against her ear. "Granmaw?" he called, and he drew a little away, where she could see him, while his wife and his children looked on, each holding one of the mother's hands. She looked straight into his eyes and her eyes and her face never changed, a look as if she were gazing at some small point at a great distance, with complete but idle intensity, as if what she was watching was no concern of hers. His father leaned forward again and gently kissed her on the mouth, and drew back again where she could see him well, and smiled a little, anxiously. Her face restored itself from his kiss like grass that has been lightly stepped on; her eyes did not alter. Her skin looked like brownmarbled stone over which water has worked for so long that it is as smooth and blind as soap. He leaned to her ear again. "I'm Jay," he said. "John Henry's boy." Her hands crawled in her skirts: every white bone and black vein showed through the brown-splotched skin; the wrinkled knuckles were like pouches; she wore a red rubber guard ahead of her wedding ring. Her mouth opened and shut and they heard her low, dry croaking, but her eyes did not change. They were bright in their thin shadow, but they were as impersonally bright as two perfectly shaped eyes of glass.

"I figure she know you," Sadie said quietly.

"She can't talk, can she?" Jay said, and now that he was not looking at her, it was as if they were talking over a stump.

"Times she can," Sadie said. "Times she can't. Ain't only so seldom call for talk, reckon she loses the hang of it. But I figger she knows ye and I am tickled she does."

His father looked all around him in the shade and helooked sad, and unsure, and then he looked at him. "Come here, Rufus," he said.

"Go to him," his mother whispered for some reason, and 
she pushed his hand gently as she let it go.

"Just call her Granmaw," his father said quietly. "Get right up by her ear like you do to Granmaw Lynch and say, 'Granmaw, I'm Rufus."'

He walked over to her as quietly as if she were asleep, feeling strange to be by himself, and stood on tiptoe beside her and looked down into her sunbonnet towards her ear. Her temple was deeply sunken as if a hammer had struck it and frail as a fledgling's belly. Her skin was crosshatched with the razorfine slashes of innumerable square wrinkles and yet every slash was like smooth stone; her ear was just a fallen intricate flap with a small gold ring in it; her smell was faint yet very powerful, and she smelled like new mushrooms and old spices and sweat, like his fingernail when it was coming off. "Granmaw, I'm Rufus," he said carefully, and yellow-white hair stirred beside his ear. He could feel coldness breathing from her cheek.

"Come out where she can see you," his father said, and he drew back and stood still further on tiptoe and leaned across her, where she could see. "I'm Rufus," he said, smiling, and suddenly her eyes darted a little and looked straight into his, but they did not in any way change their expression. They were just colors: seen close as this, there was color through a dot at the middle, dim as blue-black oil, and then a circle of blue so pale it was almost white, that looked like glass, smashed into a thousand dimly sparkling pieces, smashed and infinitely old and patient, and then a ring of dark blue, so fine and sharp no needle could have drawn it, and then a clotted yellow full of tiny squiggles of blood, and then a wrong-side furl of red-bronze, and little black lashes. Vague light sparkled in the crackled blue of the eye like some kind of remote ancestor's anger, and the sadness of time dwelt in the bluebreathing, oily center, lost and alone and far away, deeper than the deepest well. His father was saying something, but he did not hear and now he spoke again, careful to be patient, and Rufus heard, "Tell her 'I'm Jay's boy.' Say, 'I'm Jay's boy Rufus.'" 
And again he leaned into the cold fragrant cavern next her ear and said, "I'm Jay's boy Rufus," and he could feel her face turn towards him.

"Now kiss her," his father said, and he drew out of the shadow of her bonnet and leaned far over and again entered the shadow and kissed her paper mouth, and the mouth opened, and the cold sweet breath of rotting and of spice broke from her with the dry croaking, and he felt the hands take him by the shoulders like knives and forks of ice through his clothes. She drew him closer and looked at him almost glaring, she was so filled with grave intensity. She seemed to be sucking on her lower lip and her eyes filled with light, and then, as abruptly as if the two different faces had been joined without transition in a strip of moving-picture film, she was not serious any more but smiling so hard that her chin and her nose almost touched and her deep little eyes giggled for joy. And again the croaking gurgle came, making shapes which were surely words but incomprehensible words, and she held him even more tightly by the shoulders, and looked at him even more keenly and incredulously with her giggling, all but hidden eyes, and smiled and smiled, and cocked her head to one side, and with sudden love he kissed her again. And he could hear his mother's voice say, "Jay," almost whispering, and his father say, "Let her be," in a quick, soft, angry voice, and when at length they gently disengaged her hands, and he was at a little distance, he could see that there was water crawling along the dust from under her chair, and his father and his Aunt Sadie looked gentle and sad and dignified, and his mother was trying not to show that she was crying, and the old lady sat there aware only that something had been taken from her, but growing quickly calm, and nobody said anything about it. 


\section{A Death in the Family}

1. From what point of view is this story told? How might the account of the family visit have been different if it had been told from the great-great-grandmother's point of view?

2. How does Aunt Sadie react to the surprise visit?

3. What evidence is there that Sadie is out of touch with the family but that the family is strongly linked?

4. In what ways might Rufus' trip with his family to visit his aging great-great-grandmother be compared to a trip back into the past? 
208 Contemporary Authors Search for a Usable Past

Illustration No. 5

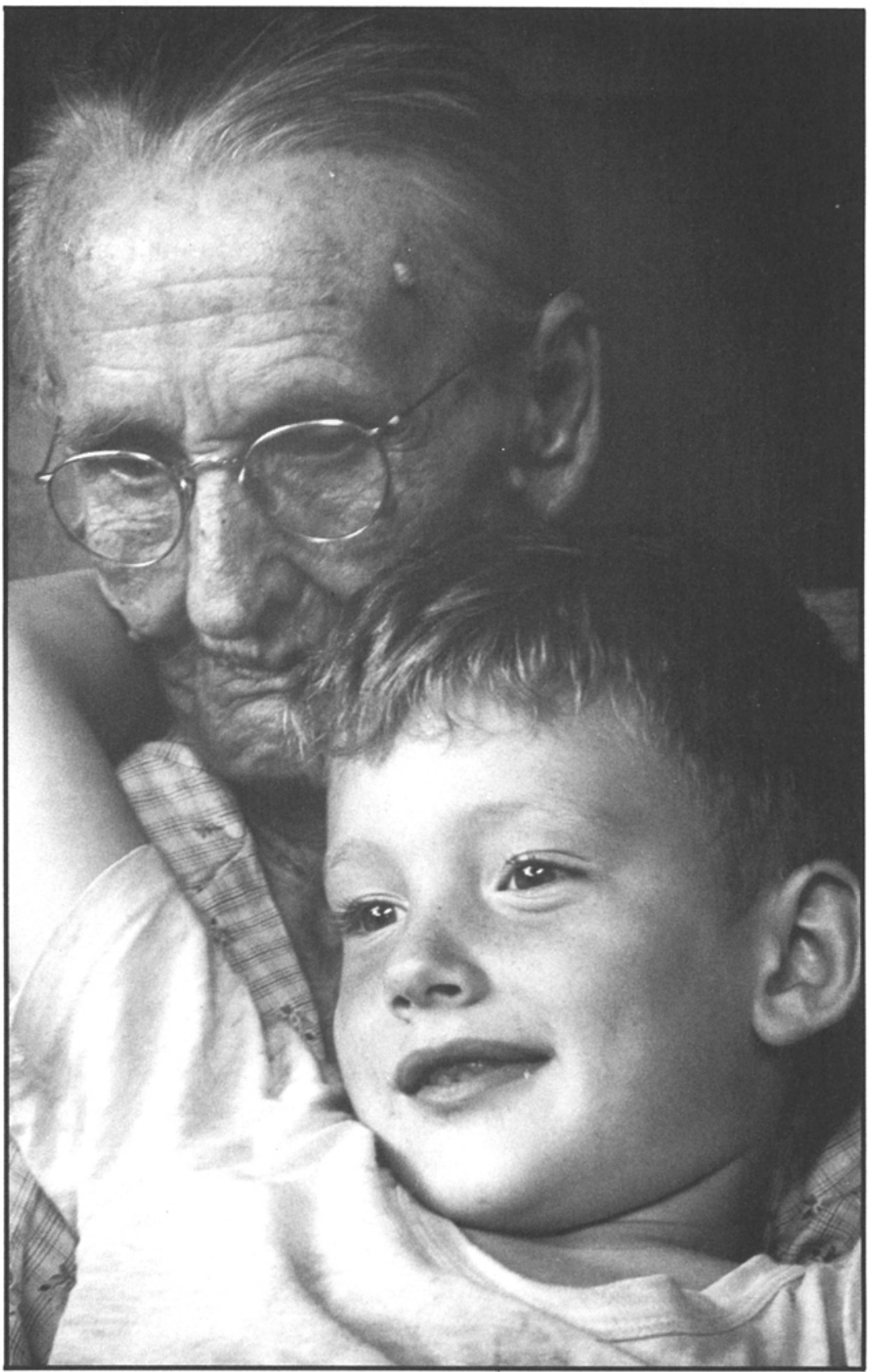




\section{LEE SMITH (1945- )}

Currently a faculty member at North Carolina State University in Raleigh, Lee Smith was born and reared in Grundy, a small town in the coal-mining region of southwest Virginia. She sets much of her work in towns suggested by her memories of Grundy.

Although she began writing as a child, her English teachers at St. Catherine's School in Richmond where she attended high school influenced her to choose writing as a career. She went to Hollins College because it had a strong writing program. While there, she realized that writing is all she ever wanted to do. She has published six novels: The Last Day the Dogbushes Bloomed (1968), Something in the Wind (1971), Fancy Strut (1973), Black Mountain Breakdown (1981), Oral History (1983), and Family Linen (1985). She also has a collection of stories called Cakewalk. Her work has twice earned the O. Henry Award for short fiction.

This short story from Cakewalk explores one of her major themes-the changing family and community in an Appalachian Mountain setting.

\section{Saint Paul}

It all started so far back-way before my daddy died, or 
Danny, and before I got myself in trouble as they say-when I was still playing jacks and paper dolls and skipping rocks in that still place at the bend of Dawson's Creek, back when I was a little girl in our house, which looked just exactly like all the others in the bottom where we lived, and the Honeycutts lived on the hill. Mr. Honeycutt owned the mine, Consolidated Coal Inc., where my daddy and the other men worked, and he owned our house too because we rented it from the company, only I didn't know that then. All I knew was that the Honeycutts' house was different from all of ours, big and white and crazy-looking, with towers that poked up all over the place, and porches that stuck right out where you never thought a porch out to be, and woodwork all over it like lace on a wedding dress. It sat a good ways back from the road, with a stone wall around the yard, and in the summertime these red rambler roses grew all over the wall. The Honeycutts had lots of grass, too, and a man they hired to come and cut it, and big old shade trees, one of which had a rope swing hanging down from it that I liked to swing on better than anything. The Honeycutts used to let me swing whenever I wanted to, whether Marlene was out in the yard or not. But usually she was, and so we swang on that swing, or played in a lean-to we made out back in the woods behind the garden, or else we played with her dolls-and Marlene had dolls from all over the world, like a little doll with slanty eyes from China and a doll from Holland with wooden shoes. I can't even remember what we all we did. Now this is Marlene Honeycutt, who was exactly four days a part from me in age, and we were best friends. We stuck our fingers with needles and mixed our blood to prove it.

Marlene's mother, Mrs. Honeycutt, wore high-heel shoes every day of the week. But she let Marlene and Paul play with the rest of us, from the time we were all big enough to cross the road-if you could ever get Paul to play, that is. Mostly we never could. Marlene had long curly yellow hair and freckles and a smile that showed all of her teeth. Paul had yellow hair too, but his was light-colored and thin and flyaway, like a dan- 
delion going to seed, and it seemed like he never smiled. He wasn't mean or anything, just serious-Paul was serious all the time. He stared hard at everything with these big old blue eyes of his that always looked soft, somehow, the way cow eyes do.

Buddy Lipscomb and Merle Rainey and the other boys in the bottom used to tease him and be real mean to him, like one time they tied him up to a tree and left him there all afternoon, and another time I remember Buddy acted like Paul had said something bad about him, and he knocked him down on the mine road and Paul's head bled like crazy when it hit a rock. Only Paul never said a word about it to anybody, never told on Buddy whose daddy would have whipped him good if he knew, and of course Paul never had said anything to Buddy Lipscomb in the first place, anyway. So after a while all the boys just left him alone, since he wouldn't fight back, and Paul stayed pretty much to himself as I recall. He used to lay up there in their yard on a hammock all summer long, reading big old books. Marlene and I went back and forth, all around the yard, playing - she had a poodle puppy then-but we didn't pay Paul any more mind than we would have if he had been a book himself. One time Mr. Honeycutt bought him the fanciest bike you ever saw, but Paul didn't ride it at all and it just sat up there in the shed. I would have died to have a bike like that but I never did ask to ride, not one time. I wouldn't have asked for the world.

I stayed clear of Paul, like all the rest of the kids from the bottom. Paul was a genius, Marlene said. I didn't know about that, but we were all glad when the Honeycutts sent him off to school because he never did anything in the schoolroom anyway but make a hundred and draw plans of buildings and airplanes and machines, mumbling numbers to himself. At lunchtime he used to eat all alone on the back steps or have a big discussion with Mr. Boling, a fat little man from. Wheeling, which was the closest big town, who came three days a week to teach advanced math and science. Mr. Boling smelled funny and blinked his eyes a lot. Paul talked to Mr. Boling in a real high voice, and waved his hands in the air. Lord! I was glad 
when Paul was gone.

And what I want you to understand here is that I never thought about Paul for one minute after he left. I was too busy at home, which I have not even said one word about so far. Of course our house was not like the Honeycutts' - they had tall dark rooms and thick rugs, and it smelled like furniture polish all the time. We had five rooms-mine and Danny's, Mamma and Daddy's, the kitchen and the front room and the bathroom, if that counts-and it smelled like whatever we were having for supper that night. We had a nice green living room suite in the front room with see-through plastic on it so it would last, and linoleum on the floors, and yellow flowers on the wallpaper in the room where I stayed with Danny. At least the flowers used to be yellow.

I don't remember my daddy much before he got hurt, except that he was a big man with a loud laugh and a real pretty singing voice. The first Christmas after the accident, I recall that Mrs. Honeycutt sent us a whole baked ham, but my mama wouldn't touch a bite! and Daddy just laid in a recliner chair back in the kitchen, near the stove, from then until the time he died. It seemed to me like he shrank up before he died.

Now my mamma, who was a worrier from the word go anyway, really started in worrying then, even though the company said we could stay in the house as long as we wanted, and we had Daddy's insurance money too from the union. But Mama used to sit in the front room shriveling up Kleenex and saying "Lord! Lord!" in that way she had. This left me to do the cooking and washing and the taking care of Danny, which I did. I didn't mind that either-he was always the sweetest child. Danny had brown eyes like Daddy's, and a happy disposition as they say. I took him everyplace with me. I was glad to have him along.

I remember one time we all took him swimming, the summer after Daddy died. Marlene went, and my first cousins Ruthie and Loretta, and Buddy and Merle and a whole bunch of us. We used to go in that hole at the bend of Dawson's Creek, where the water came off the rocks in a big rush and then it got 
real deep and you could swing out on a rope right over the deepest part. I can still see Danny swinging through the air on that long rope, how he went swooping out through the sun and then the shade in his little red bathing suit, and came up squealing to beat the band. He could swim real good for his age. Marlene and I laid out on a big flat rock and listened to her radio and watched him. We listened to Elvis Presley, who was just catching on then. I had a two-piece bathing suit and I was already getting breasts, ahead of Marlene who was still flat as a pancake, and I was feeling so good laying there in the sun that when Paul showed up all of a sudden on the bank-he was home from school for the summer-I sat up and hollered at him. "Hey, Paul," I said-I think I waved-"come on and go swimming with us." But Paul said he had some things to do. Only he didn't leave for a while. He stood right there on the bank and watched us for a long time before he left. Danny was swinging out on the rope and Merle kept splashing water on Marlene and me.

I guess I remember this whole day so good because of what happened three years later, when Danny drowned. Not in Dawson's Creek but out on the lake where he had gone fishing with some bigger boys from Ajax. This was when Danny was eleven and I was turning sixteen. I cried my eyes out, of course-it was like Danny had been my baby, in a way, and as I said he was always so sweet.

But if I thought my mama was bad before, it was nothing compared to the way she got then. She laid in the bed for three weeks solid, until the nurse from the County Health came in and gave her glucose in her veins. She wouldn't do a thing. Now here I am trying to go to high school, remember, and take care of Mama too. Finally she got up, but she wasn't the same after that.

I remember she had this calendar she had gotten from the hardware store in Ajax, and it was up over the kitchen sink to hide a hole in the wall where a pipe or something used to goanyway, we had this pretty calendar from the hardware store with a big full-color picture of four baby deer on it, drinking 
out of a spring. Now Mama got a thing about those deer. "Billie Jean," she used to tell me, "I wish you would look at that little deer to the right, there. I wish you'd just look in his eyes. Don't they look like Danny's eyes, honey? Don't they?" Then she started saying, "Danny has come back from the grave, Billie Jean, to be with us right here and now. He is looking out at me through those deer eyes, I can feel it every time I come in the kitchen, and when I walk back and forth, I tell you, his eyes just follow me wherever I go."

Now a person can only take so much of that, and I got to the point where I didn't know whether I was coming or going. Finally I thought OK, Billie Jean, you've got two choices: you can either moon around here and go crazy too, or else you can go out and have some fun. So I went. This is when I got wild, I'll make no bones about it, but I'll tell you one thing: there is only so much to do on a date in a place like that where the movie over in Ajax didn't change but once a week, and I was not the only one that did it, either. I was real pretty, thoughI looked like an Indian, people said I took after my daddy that way-and when you're real pretty, everybody just naturally notices what you do, and there is always somebody going to start something about you behind your back.

Oh, I did it all! First I started wearing makeup, then I started smoking cigarettes, then I used to take a drink of liquor if one of the boys just happened to bring it along, then I started letting them feel of my breasts when they kissed me goodnight. I didn't give a damn, either! I wanted them to touch me like they did. Well, Billie Jean, you've got to do something, is what I thought. Marlene used to ask me questions about all of it-where I went and what I did-since the Honeycutts wouldn't let her date anybody, thinking, I guess, that she was too good for all of the boys in the bottom, and I told her everything. I used to go over to her house to spend the night and we made pizza from a mix and smoked cigarettes out the window, so her mother wouldn't find out. Except she did, finally, and after that Marlene couldn't see me anymore except in school and then she went away, too, her senior year, like Paul had. 
Now, Paul-I never set eyes on him but once or twice in all those years. One summer I was kissing a boy from Ajax, Cord Parsons I think it was, in a glider on my front porch and all of a sudden I heard somebody clear their throat and say my name in the funniest voice, and when I looked up there was Paul not fifteen feet from where we sat. Paul had gotten tall and skinny, I guess he must have been in college by then. I didn't know how long he'd been standing there before he said my name. Cord Parsons stood right up and said, "Now you listen here," but by that time, Paul was gone. He had faded right off in the dark.

This was the same summer he went off hitchhiking for one solid month without a dime in his pockets in order to "find himself," according to his father, who got drunk at the 4th of July company picnic and told some men about it. He said Paul had taken a vow of silence and it was all a bunch of foolishness and he said he wished Paul would get a decent job. Mrs. Honeycutt left the picnic by herself, she was so mad at her husband I guess, and she lost about fifteen pounds that month worrying before Paul finally came home. They talked it all up and down the bottom, how Paul had gone off hitchhiking and made his mother lose so much weight, but I didn't see him again myself until one time late that August, when I was walking up the road to the company store where the P.O. is, to mail some bills for Mama, and I saw Paul sitting out in the middle of the Honeycutts' yard cross-legged, staring straight up at the sun.

"Hi, Paul," I said, but he didn't move a muscle and I don't think he even knew I was there. So I hurried right on by-Marlene had gotten stuck up by then, whenever she was home, and we weren't friends anymore and it always made me sad to see those roses on their wall. At the P.O. I told Mr. Looney, the postmaster, about Paul sitting out in the yard, and Mr. Looney said that in his opinion Paul had always had a screw loose someplace, anyway. He said he knew about cross-legged sitting, though - that was meditating, he said, like religion. He said he guessed Paul was going to turn into a saint next, ha ha! Mr. Looney winked at me. He was a smart man who could have 
really gone places, everybody said, if he hadn't stayed home for twenty years to take care of his mother.

Which was not what I planned to do! So when Jimmy Bell Dean, Jr. started asking me out when I was a senior, I was tickled to death-first because I guess I was flattered, him being so much older and a doctor's son, and then because he was so good-looking, a big blond boy like Troy Donahue in $A$ Summer Place, which I had seen two or three times. Everybody said we made the cutest couple, which we did. Johnny Bell took me to motels outside of Wheeling for the weekend, where we spent all day in those big beds and then drank bourbon and Coke in the bars that night, and I didn't give a damn what anybody thought. I was in love! I even hoped I'd get pregnant so Johnny Bell would have to marry me, but when I did, he wouldn't.

I remember when I told him I was pregnant: we were sitting up on the ridge in his red Chevrolet one winter day after he had picked me up from school, just splitting a beer and looking out at all the mountains, which had snow on them as I recall, and smoke was coming out of all the chimneys everywhere, and I had on this electric blue mohair sweater he had given me not one week before, under my coat-well, I told him, and Johnny Bell liked to have choked on his beer, so I told him again, and he put his head down on the steering wheel for a while and then he said he'd take me over to Wheeling for a rabbit test, and if I was telling the truth, we'd get rid of it. He said somebody like me wasn't going to force him into anything.

"Take me home, Johnny Bell," I said, and I slammed that door as hard as I could when I got out. And then I went ahead and had the baby in spite of them all. In spite of Dr. Johnny Bell, Sr., coming over to see my mama, wearing a hat, and saying his son would accept no responsibility, and in spite of the principal making me quit school when I started to show. Mrs. Lucas gave me a waitress job at the Ben Franklin Cafe, over in Ajax, and I remember I had gone back to the kitchen to get some french fries when my water broke. So Mrs. Lucas drove me to the hospital in Ajax herself, and I still had my 
waitress smock on.

Listen: I have not ever regretted it, not for one minute, having that baby. Now this is Betsy, who has been one of the biggest joys of my life, and she has children of her own today. A baby is a baby, is the way I see it, and they're all made exactly the same way, and the amount of paperwork involved-or not involved-does not amount to a hill of beans. Anyway I had Betsy, who was the prettiest little child right from the start. And one day when Betsy was not but three weeks old, the funniest thing happened. I went out to get the mail and there was this white envelope in the box. Typed, with no return address. I took it in the house and opened it up, and it had six onehundred dollar bills, folded up in a sheet of plain white paper. Not a word on that sheet! When I showed all this to Mama, she liked to have died. She dropped a pan right in the floor as I recall.

"Well, I guess it's from the Deans," she finally said, and said if it was, then I was going to throw every bit of it straight in the fire.

"Now, Billie Jean," my mama said, but I went right over to the phone and called up Dr. Dean at his office. Not in, they said. I told them who I was and said it was an emergency, and of course he came to the phone right away.

"Certainly not!" Dr. Dean said when I asked him if he or Johnny Bell had sent me that money in the mail. "As far as we are concerned, young lady, any connection we have had with you is at an end."

"Well, that suits me just fine!" I said, and hung up on him.

That money came in handy, too-I called it the mystery money-and we lived on it until Betsy was three or four months old and I went back to work for Mrs. Lucas at the cafe, and then when she retired, I took over as manager of it. It was long hours, but I didn't mind it, the pay was OK and the people were nice, and I had Betsy to come home to every night. I couldn't for the life of me remember exactly why it was that I used to like to run around so much. As for Mama, she had perked up considerably having Betsy around, to the point of 
her being almost a normal person again.

It was about two years later that I married Loyd Raymond, a druggist in Ajax who came in the cafe for about thirty cups of coffee every day for a month and a half before he ever got up nerve to ask me out. Loyd was shy but he was sweet, and he was just crazy about Betsy: he used to play hide and seek with her out in the yard, just like a kid. He used to get down in the woodpile and then jump out. We built a new brick home around the bend from the bottom where we had lived all those years, and we had another baby, Loyd Junior, and my mama lived with us until she died. So I was married to Loyd Raymond for eighteen years in all, and I couldn't complain of a thing. Loyd was an easy man to get along with, and a good man, and I have to say it - he was just crazy about me, too. If he knew I wanted something, he'd go right out and get it before I even opened my mouth. We were both of us funny that way $\rightarrow$ lot of times we' $d$ be thinking the same thing, and then we'd say it out loud together. Loyd bought me a diamond dinner ring for our tenth anniversary, and every summer we went to Myrtle Beach. I never looked at another man while he was alive, even though Loyd himself wasn't much to look at-but he was one good man to live with, I'll say that. It was such an awful shame when he died so young, but a bad heart runs in his family, and after I got over the shock of it I went back to the community college and got my CPA license, and turned what used to be the den into my office. So I have made a decent living, and the kids turned out good if I do say so myself, and I can't say I spent much time thinking about the Honeycutts even though I passed their house at least two times a day, coming or going to the P.O. up at the store, or maybe over to Ajax.

I did go by there right after Mr. Honeycutt died, to tell Mrs. Honeycutt I was sorry and to take her some potato salad, because I believe in letting bygones be bygones and she was a good woman in her way.

"Thank you so much, Billie Jean," she said in this wavery voice, and she said how cute Loyd Junior was. I had brought him along, too. I asked after Marlene and she said Marlene had 
been married previously, and then divorced, but that now she had remarried and seemed quite happy. Mrs. Honeycutt's voice went up and down on the "happy," and tears welled up in her eyes. She was all bent over in one of those big ugly armchairs that I used to think were so beautiful-now, you can give me French Provincial any day! - and I could see that she herself was not long for this world either. So then I asked after Paul, too, just to be polite, and Mrs. Honeycutt said that Paul was a professor of philosophy and religion at one of those big famous Eastern universities-I forget which one she said, but you would have heard of it. She said Paul had never married much to her dismay, and so she had no grandchildren at all since Marlene had never had any children, either. Then she started to cry again.

"There's one of the books Paul wrote," she said, pointing to a big thick book lying there on the coffee table with all the sympathy cards and little figurines and things she kept around. "But you can't read it," she said.

I picked it up. "Why can't I read it?" I asked.

"Well, I mean you wouldn't want to," Mrs. Honeycutt said, and she smiled for the first time since I had been there. "It's all about the nature of God as different people have thought of it through the ages, or at least that's what it says in the introduction, but you couldn't prove it by me. I tell you, it's dry as a bone."

I laughed and put the book down on the coffee table. "Paul always was a brain," I said.

"He certainly was!" Mrs. Honeycutt said. "He..." but then I guess she forgot what she was going to say next because she let her voice trail off into thin air and just sat there, staring through me like I had already left. So I did, and as soon as we got in the car, Loyd Junior said he was glad to get out of there. He said that house gave him the creeps.

I was not surprised when Betsy came home from work about a month later with the news that Mrs. Honeycutt had passed away in her sleep, and I went over there again, to see if I could help, when I heard that Marlene had come home to 
clean out the house.

"Oh, Billy Jean!" Marlene said when she opened the door and saw me standing there. "Look at you! You're just the same, I'm so glad to see you, oh look at you!" she said, and hugged me, and for a minute it was almost like it had been before we smoked those cigarettes out the window and she had to go off to school. Almost. But I was a widow with a grown daughter and a nice big son and a business of my own by then and I'll admit it-I have filled out some, you might say. And I've got these streaks of gray in my hair that I won't let Neva at the Clip 'N Curl touch up-"I earned that gray hair!" I tell her, "and you just let it alone!"-and anyway I guess I look a good ten years older than Marlene. Marlene had spent a lot of those years-you can always tell it-holding onto her looks, and she was as thin as a rail with her hair all frizzed out in one of those fashionable new hairdos they wear now. Marlene looked like a model out of Cosmopolitan magazine, and every piece of jewelry she had on was solid gold. She smoked a lot, though, and picked at things with her nails. "Can I help you with the house?" I asked, and she said maybe I could help her supervise it, but the company had hired a bunch of women for her and they were already packing everything up. And they were, too-you never saw so much carrying on and packing in your life. So we just sat down in the middle of it all and had us a long heart-to-heart, and that was when Marlene said the strangest thing:

"You know," she told me, and then she laughed and said, "Well, you don't know, I know you don't, how much I envied you when we were teenagers."

"Oh, come on Marlene," I said, but Marlene swore that it was true.

"I wanted to be just like you, I even wanted to look just like you, and I wanted to do everything you did. I was just so bored with my life..." and she went on about how her boredom had gotten her into her first impossible marriage, which is what she called it, but she said that now at least she was getting her feet on the ground, and again I had that funny feeling that she had 
somehow gotten years and years younger than me-but then she dropped the bombshell.

"I'll tell you something else you never knew," she said. By then we had found two little green glasses and we were drinking some sherry wine. "My brother, Paul, was always in love with you, too. We were both kind of in love with you, if you know what I mean, only I believe Paul was really in love and he never got over you, either."

"Why Paul never even asked me out!" I said, and she said it was probably because I used to be so wild and all, and Paul knew he couldn't compete. But she said she always thought he wouldn't have loved me, either, if I hadn't been so wild, and I said this was all hogwash in my opinion, and then we got to giggling and giggling and finally we went upstairs to see how the women were coming along in the linen closets and the cedar closet and the bedrooms. They were almost through. Everything was stripped and your voice echoed out in all the rooms. Except for one-Paul's-because Marlene said Paul had asked expressly that she leave it alone since he was coming back here to spend the fall semester and write another book before they sold the house, and so the women had not been in there at all.

Now this is something I would not ordinarily have done, I'll admit it, but I was so confounded by what Marlene had just told me, and I had drunk that sherry wine-anyway, I went in Paul's room and-I'll come right out and say it-snooped around, while Marlene was down in the front hall writing all those women a check. At first I found exactly what you'd think-books and books, lots of stuff like chemistry sets and little old scale model kits of buildings, like cathedrals for instance, instead of airplanes which you would normally expect to find in what had been a boy's room, only of course that boy was Paul. But then in a closet, on a shelf with a lot of other boxes holding collections of various sorts, I saw this fancy wooden box with initials carved in the top, $B J \mathrm{~L}$, and those were my initials, you know, before I married. Mine! Well, I didn't have much time. Icould hear Marlene's voice and the women's 
voices in the downstairs hall, all of them going up like voices do when people are saying goodbye. But I opened the box anyway-I would have died if I hadn't opened it-and sure enough, it was full of things about me, such as that red velvet bow I used to wear in my hair, and my initial ankle chain I lost the year I was fourteen, pictures the Honeycutts had taken of us all in their front yard, and weird little dried-up flowers and stuff like that. All of a sudden I felt like I was going to get sick to my stomach. Also I heard the door close down there in the front hall, so I took one picture out of the box, to keep-Marlene and me and Paul by the rope swing, grinning into the sun-and then I closed the box back tight and shoved it to the back of the shelf. It made me sick, as I said. In fact my heart was beating so bad I thought I was going to have a cardiac arrest, which I did not. In fact I hugged Marlene goodbye, and told her how good it was to see her - this was true-and I drove straight home and never said a word to anybody, not even my first cousin Ruthie who is divorced and lives next door now, about what Marlene had said or what I'd seen.

But I did stick that picture of us three children up in the corner of the mirror of my bedroom, don't ask me why. I wasn't about to put it in a frame or anything, like I keep all the pictures of Loyd and Betsy and Loyd Junior and so on, but I stuck it up there in my mirror just the same, while I went on about my life. I started to date a little bit, just for companionship primarily, and also I made some money that year on a piece of land I'd bought earlier, and so that summer I took the kids to Disney World even though I thought Betsy was too old to enjoy it-but you're not ever too old for Disney World, as we found out. We all had a fine time. I never thought for a minute, all during that summer, about what I must have known, some place deep down inside of me, what I was going to do when Paul Honeycutt came back to live in their house that fall.

I wasn't even nervous knocking on the door. This was early September, marigolds still blooming, overgrown, along the walk. Nobody came and I knocked again. I knew he was 
in there, and sure enough, after another minute or so, he opened the door just a crack.

"Yes?" he said. Then he said, "Billie Jean?" His voice still went up at the end.

"It's me, all right," I said. "Aren't you going to open up and let me in?" and so he did, and in I went.

Age had been good for Paul Honeycutt, I saw right away, like it sometimes is for a man. He was still tall, still skinny, and his blond flyaway hair had thinned to a kind of adorable fuzz around his ears. Anyway, it struck me as adorable right then. He had big thick glasses, which looked good. The glasses seemed to hold his features in the right place on his face. Paul Honeycutt looked exactly like what he was, a brainy professor who didn't have anybody to take care of him. And this was obvious, too, by the shape the house was in-dusty, and what little furniture was left was mostly covered up with old white cloths. It looked spooky.

"Now you know me and you know I have never believed in beating around the bush," I told him, and I took off my red cardigan sweater and dropped it over a wingchair and went straight up to him and put my arms around his waist. "I know everything!" I said. "I know how you sent me that money right after I had Betsy, and I know how you have felt about me all my life. So don't try to deny it, Paul Honeycutt, I know! And I'll tell you something else"-I was holding him so close that I could hear his heart just beating like a bird batting around inside of his chest-"we are not old people right now, either one of us, and it's never too late to make up for lost time."

But Paul Honeycutt pushed me away. Shoved me so hard I turned my ankle, almost fell. "No," he said. "No, Billie Jean, you don't understand-" and he fluttered his hands in the air, back and forth, like he used to do when he talked about math with Mr. Boling, back in school. He acted like he was scared to death, like a man who has seen a ghost. "It wasn't you, it wasn't ever really you, it was the idea of you, which made possible the necessary - " and he went on, and then I started noticing some other things about him that I hadn't seen at first when I came 
in, how his eyes rolled back and forth, and he wore his pants so high, and the corners of his mouth jerked when he talked. "I couldn't possibly," he said. "I could never actually-"

But I had heard enough. "Well," I said. "OK. If you're so dumb you'd rather have the idea of me than the real me in the flesh, as they say, then you can keep it. Goodbye!" I said, and walked right out and slammed the door. My ankle hurt but I kept walking even when I remembered my sweater I wasn't about to go back and get it, I'll tell you that! So I left my sweater in that house, and it's there to this day, only he's probably put it up in a wooden box or something, in his room. Who knows?

And I don't care. I've got my own business to think about and also I am considering marrying this Preston P. Diggers, who I met at a CPA convention in Wheeling, and who has got serious intentions, it looks like, in my direction. He's a real nice man. I'd have to be a fool not to snap him up when he pops the question, which I am sure he will. As for Paul Honeycutt, poor thing, he never went back to the university, or wrote his book, and so they never sold the house and he's still there. He doesn't come out except to walk to the company store for groceries, I hear, and his hair is wild and white and he talks to himself on the road as he goes. My grandchildren, Betsy's girls, run when they see him coming, that's a fact. All the children do. Its been six or seven years since he came back. But here's a funny thing: as much as I love Preston Diggers, which I do, I have never yet taken down that little picture of Marlene and Paul and me which I stuck up in the corner of the mirror so long ago. And sometimes late at night when I'm brushing my hair before I go to bed, or I get up early and look in the mirror before it gets really light outside, you know, when the bedroom is still fuzzy gray, why it seems to me that Paul Honeycutt is looking right out at me from his little-boy face, staring straight into my eyes, and I know what my mama, bless her heart, meant about my little brother Danny and that deer-and all of it strikes me, for a minute, as so sad. 


\section{Saint Paul}

1. How do Paul's differences separate him from others?

2. Throughout the story, Billie Jean suffers many hardships. What qualities does she possess that enable her to endure?

3. Find examples of Billie Jean's family loyalty.

4. At the end of the story Billie Jean is convinced that Paul loves her, but he shoves her away. What does Paul mean when he says, "It wasn't you, it was the idea of you..."? 


\section{LOU CRABTREE (1913- )}

Lou Crabtree left Abingdon, Virginia, her birthplace, only long enough to earn a degree from Radford University and to study drama at the American Academy of Dramatic Arts in New York. She taught school for thirty-six years to children, teen-agers, adults, and foreigners learning English. She is also a farmer.

She has had stories published in many literary magazines. In 1984 the Barter Theatre toured "Calling on Lou," a dramatic presentation of her poems and short stories. In 1984 Louisiana State University Press published her first collection of stories, Sweet Hollow.

This story from Sweet Hollow, told by a child, creates sympathy for Homer, Old Marth's blacksnake.

\section{Homer-Snake}

Old Marth claimed all the blacksnakes were hers. She tongue-lashed the roving Murray boys, who went into people's barns and caught snakes and took them by their tails and cracked them like whips. This cracking broke the body of the snake and sometimes snapped off its head. It was terrible to see the Murray boys wring a snake around a few times, then give a 
jerk and off snap the head.

Old Marth lived in her cabin next to our cabin down in the hollow of the river hills. She pinned her gray hair with long wire hairpins. I watched her stick the wire hairpins into her hair with little flicks of the wrist. It hurt her head, I thought. Only when she was bothered did her hair escape the pins and fall in gray wisps about her face. Bud, my brother younger than I a few years, thought it his mission in life to trail me, to spy, and to report on me to Maw. Some things Bud would tell but not many. Only things on me. Bud said I told everything I knew. Maw said it, too. Because of this, Bud never let me trek over the hills with him.

He said, "She just can't keep from talking. She talks all along the trace. If you talk, you don't get to know anything."

Old Marth leaned down close to Bud. "Blacksnakes are best of friends. Come down to my house and I'll show you Homer-snake."

I had seen Homer-snake many times. Bud had, too. Homer had lived for years back of Old Marth's house in the corner of the outside rock chimney. A hole was visible, where for warmth Homer crawled in the winter.

I once asked Old Marth, "Did Homer-snake dig his hole by himself?"

Old Marth replied, "I expect it is a once frog hole."

What Old Marth told Bud next was not news to Bud or to me. We had both seen it a million times.

"Homer-snake likes milk to drink. I put out milk for him in his saucer every day. Best of all he likes cream, which I don't give him but ever once in a while. He might get too fat to go in his hole." Old Marth laughed, then fiercelike advanced close to Bud. "Don't you ever come to be tormenting blacksnakes. I'll be wastin' my breath if you come to be like them rovin' Murray boys. Come to my house soon and get better acquainted with my Homer-snake."

Old Marth wouldn't have liked what Bud was carrying around in his pocket. I asked him what the small white rocks were that looked like they were rolled in salt. 
"Blacksnake eggs. I found them under a rock up the ridge."

Old Marth was always asking me to go home with her to spend the night. She never asked Bud. He tried to devil me behind Old Marth's back.

"How would you like to turn down your bed covers and there would be Old Homer all curled up warming your bed?"

Then I accused Bud of being jealous, and we got into one of our many spats until Maw moved in, saying, "Old Marth just don't like boys. She is suspecting on account of them Murray boys."

Bud never was known to give up. He used to slink around the house as I was leaving, and peep around the corner, and hiss, "Don't sit down on Homer-snake."

Behind Old Marth's house and up a little rocky path was her vegetable garden. To one side was her little barn where she kept her cow, some hens, and a red rooster. The rooster did not like Homer and gave him many a good flogging. He raked Homer with his spurs until Homer fled from the barn, leaving the rooster and hens alone.

Nevertheless, on the sly, Homer would steal into the barn where he unhinged his jaws and swallowed whole one of the hen's nice eggs. Then off he would sneak, toward the rocky path, where he knocked and banged himself against the rocks until the prongs on his ribs crushed the shell of the egg. Once I saw Homer with a huge knot along his body, and I rushed to Old Marth, alarmed.

Old Marth answered in a knowing way. "Most likely an egg. Could be a mouse or a baby rabbit. Homer-snake is having his dinner."

Once the Murray boys were out "rogueing"-knocking off apples and stealing eggs. Homer was in the warm hen's nest where the hen had just laid a nice egg. Homer liked the warmth and was nestling down and warming himself before swallowing the egg, which was sort of an ordeal for him. A rude hand, reaching into the nest, and pulling out Homer, let go quickly. Even the Murray boys didn't like surprises like Homer.

"Homer is my protection," cackled Old Marth as the Mur- 
ray boys skirted her place, skulking about carrying an old sack they put their loot into. Old Marth guessed that the Murray boys were out to get Homer. Twice they were almost successful.

Homer loved to climb trees. There were young birds and other delights. He played hide and seek up in the sycamore tree down by the little springhouse. He climbed to the very tiptop and out of his snake eyes viewed the world. I liked to watch him hang like a string and swing in the sycamore tree.

On this particular day, Old Homer had left the sycamore and was up in the tree that had the squirrel's nest. It had once been a crow's nest, but the squirrels had taken over for the summer. In the winter they had a fine home in a hole just below the crow's nest.

Homer liked young squirrels almost as much as young rabbits.

The Murray boys almost got Homer that time. They spotted him up in the tree that had the squirrel's nest. Climbing a tree was nothing to the Murray boys. They could climb to the top of any tree in the Hollow. Homer-snake was in a predicament. The leanest of the Murrays was coming right on up the tree with no problem. Homer couldn't see Old Marth anywhere. It would be too late in a minute. A rough hand would be reaching for him.

There were some small limbs, too small to hold the weight of a boy, and farther on, still smaller limbs that just possibly could hold up a snake. Out crawled Old Homer and with great care coiled himself round and round the smallest ones.

The Murray boy was plain mad. The limb would not hold up his weight. He ventured out as far as he could and leaned out and down and stretched his arm toward Homer.

"Shake him loose. Shake hard."

Round and round the tree looking up, calling louder and louder, went the rest of the boys until the red rooster brought together his pack of hens and they all set to cackling, which caused the hogs to trot around the pen, grunting. Just in time, out of the house, like a whirlwind, came Old Marth. The Mur- 
ray boys knew to make themselves scarce and they hightailed it, except the one caught up in the tree who tried to skin down fast. Old Marth got hold of his hair and yanked him about, and when he left, he left a piece of his shirt with Old Marth.

Laughter floated backwards as the Murray boys hightailed it, putting distance between them and Old Marth's screeching.

"Rogues! Torments! Thieves!"

So Homer was saved this first time.

Another time, the Murray boys were watching Old Marth's house and knew she was away. They were walking around looking at the roots she had tied up to the rafters of her porch. They had been down to the hogpen and down to the springhouse and had drunk out of the gourd. They spied Homer, who was coming from the garden. He barely got halfway in his door when one of the Murrays got him by the tail, straining and tugging to pull him out. What they did not know was that no one, not anyone, can pull a snake out of his hole, once he gets part way in. The snake swells up and spreads his scales and each scale has a tiny muscle. The snake may be pulled into two parts, but he will never be moved. The Murray boys did not give up easy as they pulled and tugged.

"Pull harder. Yank him outa there.

Homer was about to come apart when he felt footsteps coming along on the ground. Old Marth, home early, came upon the scene and chased off the Murrays with a tongue-lashing they would remember. Homer-snake was saved the second time, but there was to be a third.

In the late summer, Homer got a new skin. He molted. He had a bad case of lassitude. Then his whole body was itching so he could not rest. His lips began to split and his eyes turned milky. He made trip after trip up into the garden, ate a big bunch of snails and bugs, and lazed back down over the rocky path.

One day there was his old skin beside the path in the rocks. Of course he knew all along what he was doing and just how to do it. He rubbed and rubbed himself against the rocks until his old skin loosened and he rolled it off wrong side out. Just 
like Bud shed his clothes.

Old Marth found the skin and tied it with several others to the rafters of her porch. When the wind rattled them, they scared me, but not Homer's enemies, the Murrays.

Old Marth said to Bud after Homer shed his skin, "I will make you acquainted with the new Homer. Don't you like him? Ain't he handsome? Like a new gun barrel, he is."

With his new skin, Homer was so shiny and new, I think Bud almost liked him. Homer looked "spit shined," like Paw said about his shoes from his old army days.

Homer got along real well with the cow. She ignored him and never got ruffled if she came upon him suddenly. Homer only had to watch her feet. She did not care where she stepped. Four feet were a lot to watch and one day Homer got careless. One of the cow's feet came down hard on about three inches of Homer's tail. When Homer looked back, the end of his tail was broken off and sticking out of the mud in the cow's track. His beautiful tail. So for the rest of his life he went about trailing his blunted tail, and after a while he didn't seem to miss it.

Bud said, "I can always tell if it is Homer trailing through the sands and dust. Among the squiggles you can see where his old stepped-on tail went."

Down in the springhouse Old Homer guarded the milk crocks. He would curl around a crock like giving it a good hugging. Old Marth had to keep the lids weighted down with heavy rocks so Homer wouldn't knock the covers off and get in the milk.

Looking back, behind the springhouse, was a swath of daisies with bunches of red clover marked here and there, winding all the way to the top of the ridge. This swath was Homer-snake's special place. He liked to lie and rest and cool off among the daisies. He played all the way to the top of the ridge, got tired and slept, had lunch along the way, slithered down when he chose, spending the whole of a summer's day to arrive back home in the cool of the evening. The daisies gave Homer-snake a nice feeling.

The Murray boys were Homer's end. This was the third 
encounter.

"All things have an end." Maw said later.

Maw sent me down to Old Marth's place to swap some quilt pieces. Going to her house was all right if I could locate Homer. Sitting on Homer or having him swing down from a rafter and touch me on the shoulder never got any less upsetting. But something bad was waiting for us all that day at Old Marth's place.

Homer was fat and lazy and full of cream.

"I'll put in a spoon of jelly for you, Homer." Old Marth put the jelly in Homer-snakes's saucer and went on her way. She was going over the hill to visit and take a sample of the jelly.

Homer loved the jelly. Then I know he began feeling lonely. Loneliness led to carelessness. He failed to notice that everything was too quiet. The birds were quiet like the Murray boys were in the vicinity. The chickens were quiet like a hawk was circling. Homer decided to slip past the rooster and go into the barn to rest.

The Murray boys were out "funning" all day over the hills. They were stirring up bees' nests beside the trace and getting people stung. They were running the cows so they wouldn't let their milk down. The were riding the steers and tormenting the bull.

They saw Old Marth going over the ridge and grinned at each other and jammed down their old hats over their ears and hitched up their britches. Preparing themselves. Preparing to steal eggs out of the hens' nests, they went into the barn. Bud saw it all and told Maw.

Maw said to me, "There is such a thing as keeping your mouth shut."

Bud was watching the Murray boys that day. He had trailed them and watched from the far edge of the woods on the top of the hill. Bud was always watching. I saw him in the plum grove. He was no partner in what happened.

The Murray boys went into the barn with their everlasting sack, stayed a few minutes, rushed out toward the hogpen, pitched the sack, and whatever was in it, over to the hogs. Then 
they laughed and shouted and hightailed it.

I saw it. Bud saw it. I ran to tell Maw.

"They threw the sack and Homer in it into the hog pen. The hogs will eat up Homer." I was running, screaming wild, and blubbering.

I was so excited with telling the tale that I had not had time to feel sorry for Homer. The hogpen was one place Homer never fooled around. Even Homer knew that hogs ate up blacksnakes.

Bud had come up. "How are you going to keep her from blabbing?" Bud thought he was the world's best at keeping his mouth shut. He gloried in keeping secrets.

I wanted to talk about what I saw, and I wanted to bring it up ever afterwards and keep asking questions. There was so much to wonder about.

"She will tell her guts," Bud said.

"Let Homer bide," was what Maw had said to me and meant it. I could tell for her mouth was a straight line across.

Old Marth came home, missed Homer, and looked everywhere. Bud and I stood around and watched her. Her eyes were on the ground looking for some sign, trying to find a trail.

I mooned around and was about sick seeing Old Marth with her graying hair stringing and wisping about her face. Until one day, Old Marth said, "If Homer were alive, he would show up. I know when to give up hopes. I resign myself."

Determined not to let anything slip about Homer, for a while, it helped to clap both hands over my mouth when questions began popping in my head. I didn't want ever to be the first one to tell about Homer being eaten by the-I must not say it now.

Maw kept saying, "Let it bide a while."

Old Marth came back to our house to churn. Her hair like a cap was pinned up with long hairpins. Maw required neat hair around the butter, for a hair found in the butter made a bad tale up and down the Hollow.

I kept holding both hands over my mouth to keep from tell- 
ing until one day Old Marth noticed and said, "You are acting funny." Turning to Maw, she said, "The child is sick. Goes around all the time about to vommick holding her hands over her mouth. Just might be she is wormy and needs a dose."

I wasn't sick. Maw knew it. Bud knew it.

Days went by, to a day when I went down for a look in the hogpen. The hogs grunted, pointed their ears, and looked up at me with their little pig eyes close together.

There under the slop trough I saw it. The proof I was not seeking. I saw a piece of old sack. I screamed what the whole world already knew. "They threw the sack and Homer in it into the hogpen. The hogs ate up Old Homer." I leaned against the pen and I retched until I spit up. I was really sick. The hogs saw it. Bud did, too, for he was in the plum grove, spying as usual. I started running, jumped some puddles, got tired, and came to stop where some daisies covered with dust were beside the road.

I began feeling nice. The daisies were nice. Old Marth's place behind me was nice. Up overhead the fleecy sheep clouds stood stock still to become masses of daisies. Over to the left was a patch of red-sky clover. Then the sheep clouds moved together and formed a maze and across the sky was a swath of daisies. Just like the swath Homer had traveled up the trace to the top of the ridge. I was delighted and looked a long while. I know I saw it. There placed in the maze of daisies he loved so well was Homer-snake. He stood upright on the end of his blunt tail and looking over the daisies, he laughed at me.

I laughed and went home.

Maw's kitchen was nice with smells of sassafras tea, spicewood, gingerroot, milk cheeseing, and cold mint water fresh from the spring.

Bud came in the door, reporting on me. "Maw, I saw her. She has been down to Old Marth's hogpen."

"Whatever for, child?"

Maw didn't expect an answer, and I had already turned my back on Bud. I felt something new in my life. The day was 
coming soon when I could handle Bud. Maw refers to it as patience. Patience was something Bud did not have. Bud hung around, waiting on me to start talking and telling everything. I sat until Bud gave up and left, then I told Maw, "I saw Old Homer-snake among the daisies in the sky. He stood up on his blunt tail and laughed at me."

Maw left her dough-making with flour up to her elbows, she took my head in both hands. "Precious. You saw what you hoped for, for Homer. Homer-snake is all right. You are all right. Find your little pan. You can come help me make up this bread."

\section{Homer-Snake}

1. Two conflicts are evident in this story, Old Marth's conflict with the Murray boys and Bud's conflict with his sister. Discuss the resolution of these conflicts at the end of the story.

2. What factual knowledge about black snakes do you gain as you read "Homer-Snake"?

3. Describe the three attempts the Murray boys made to capture Homer.

4. At the end of the story, how does the young girl join Old Marth to show her affection for Homer-Snake?

5. Are you satisfied with the ending of the story? How might you have changed the ending if you had written it? 


\section{ELIOT WIGGINTON (1942- )}

A lichen which glows in the woods of Southern Appalachia on dark nights, Foxfire is also the name given to the publications of Eliot Wigginton and his students in Rabun Gap, Georgia. Wigginton and his students learn and record the heritage of the Appalachian region.

After graduating from Cornell University in 1966, with an A.B. in English and an M.A.T., the idealistic Wigginton began to teach students, who were more interested in pranks than in English.

One day in desperation, he walked into the class and asked, "How would you like to throw away the text and start a magazine?" This began Foxfire, a magazine which now has subscribers in all fifty states and a dozen foreign countries. Nine books by the same name record the heritage of the Appalachian region.

Wigginton's students turned to collecting hunting tales and ghost stories and recording folkways such as how to plant by the signs, kill hogs, make soap, build log cabins, and gather medicinal plants like ginseng.

Ginseng, which grows wild in the mountains, is known for its healing powers. Because the roots bring a high price, it provides a cash crop for mountain people who know where they can find a patch of "sang."

One of Wigginton's students, Marie Mellinger, published 
the following piece of research on the gathering of this native plant.

\section{Ginseng}

From the Himalayas to the Blue Ridge, and for as long a time as distance, ginseng has been a favored medicine. The American ginseng (Panax quinquefolium) is very similar to its Asiatic relative. It has a stiff stalk holding two leaves, each leaf five-divided like fingers on a hand, and vaguely resembling those of the horse chestnut. A small umbel of insignificant yellow-green flowers is followed by red berries. It takes two years to come up from seed, and if a plant has been injured, it might not send up a stalk until the following year. It is slow-growing and long-lived if left alone. The aromatic roots are the part used for medicine, although occasionally tea has been made from the leaves.

It was once found in rich bottom lands from Canada to Florida. William Gillespie wrote, "It is most common in beech woods." Another writer said, "It grows mainly in well-drained upland hardwoods, mixed stands of maple, basswood, butternut, and rock elm, or on the shady side of deep gullies where there is a transition in timber and vegetation mixes." William Bartram, traveling near Keowee, South Carolina, wrote, "It appears plentifully on the north exposure of the hill, growing out of the rich, mellow, humid earth, amongst the stones or fragments of rocks." Associated plants have been listed as maidenhair fern (Adiantum), baneberry (Actaea), spikenard (Aralia racemosa), blue cohosh (Caulophyllum), yellow ladyslipper (Cypripedium), and the "little brother of the ginseng," the goldenseal (Hydrastis canadensis).

Our native ginseng first came to the attention of Europeans when Father Joseph Lafitau, who had been a missionary in China, recognized the similar American plant growing near a Mohawk village in Canada. He set up ovens and had the Mohawks gather and cure ginseng for the Chinese market. By 
1717 , it was being bought from as far away as Green Bay, Wisconsin, by the Fox Indians, and shipped to Hongkong via France. In 1784, the Empress of China sailed for Macao with a load of ginseng to exchange for tea, ginger, silk, and camphor. Also in 1784, George Washington wrote, "In passing through the mountains, I met a number of persons and pack horses going over the mountain with ginseng." In 1793, Andre' Michaux wrote that ginseng was the only product of Kentucky that could be transported overland to Philadelphia.

By 1798 , John Drayton of South Carolina said, "It is so much sought after by the Cherokees for trade it is by no means as plentiful as it used to be in this state." Ginseng gathering had begun to be a way of life for many pioneers. A man could go "sang hunting" and return with a fortune; or in those perilous times, might never return at all.

The early colonists not only gathered ginseng for sale, but used it in tea to encourage the appetite or strengthen the digestion, especially of elderly persons or puny children. Ginseng plus blackcherry and yellowroot made a potent tonic, especially with the addition of some home made whiskey. An early herbal suggested gathering ginseng root and steeping it with chamomile flowers for fainting females.

Colonel Byrd, in his History of the Dividing Line, wrote, "To help cure fatigue, I used to chew a root of ginseng as I walked along. This kept up my spirits. It gives an uncommon warmth and vigor to the blood. It cheers the heart of a man that has a bad wife, and makes him look down with great composure upon the crosses of the world. It will make old age amiable by rendering it lively, cheerful, and good humored." Many early settlers dug ginseng root for their own use and never thought of selling it. By 1800, several patent medicines on the market featured "seng," or "sang-tone." Dr. McMasters of Michigan wrote, "Ginseng is a mild, non-poisonous plant, well adapted to domestic as well as professional uses. In this respect, it may be classed with such herbs as boneset, oxbalm, rhubarb, and dandelion. The medical qualities are known to be a mild tonic, stimulant, nervine, and stomachic. It is especially a remedy for 
ills incident to old age."

With some domestic sale, as well as a continuing foreign market, "sanging" became a business in the rich deciduous forests of the American heartland, and on the slopes of the Catskills, the Poconos, the Alleghenies, and the Appalachians.

It was inevitable that some would try to cash in on such a profitable and easy crop by cultivating it. Thus there was a craze for ginseng gardens from 1889 through 1905, with centers in Amberg, Wisconsin; and Chardon, Ohio. Later New York state and then Michigan became the centers of ginseng production. Ginseng was planted in beds shaded by lath slats, or under wire covered by fast growing annual vines. But growers found it took seven years to produce roots large enough to market, and then the roots lacked the quality of those gathered in the wild. Garden plants were subject to a variety of wilts, blights, and rots, and a whole garden could be decimated in a week. But even though they were a gamble, ginseng gardens continued to appeal to many who wished to make an easy fortune.

However, the most money continued to be in gathering wild ginseng. Around 1922, someone wrote, "Grandma B. took out the back seat of her Model $\mathrm{T}$ and filled it with ginseng and sold the load for $\$ 1,100$. They dried the roots on shelves behind the stove." As ginseng disappeared in more settled parts of the country, sang hunting in the Appalachians continued. Maurice Brooks wrote that it was one of the few crops that could be sold for cash with which to pay taxes or buy a new gun or hound dog. The sang hunter would go off into the mountains or woodlands with his special sang-hoe made of rigid steel with a narrow blade. The average-sized wild roots weighed up to six ounces when dug, and an expert sanger could grub out two pounds in a day. As they dried, usually from the cabin rafters, it took five pounds of fresh root for each pound of cured or marketable root.

The conservative sanger only dug roots in the fall of the year and carefully replanted the seeds, or the rhizome extension called a "quill," or "bud." To keep ginseng from being com- 
pletely killed out in an area, some sangers would carry seeds and plant them in other suitable locales. There were, however, those greedy individuals who gathered sang at any time of the year, and did not hesitate to rob a neighbor's patch. Sang hunters would try to find out where their competitors had success, and in turn would keep their own finds a secret. By 1913, Horace Kephart, in Our Southern Highlands, wrote that ginseng had been exterminated in all but the wildest regions.

After the War in Korea ruined most Oriental ginseng lands, the sale of ginseng roots reached a new peak, the price rising to $\$ 35.00$ a pound for wild roots. Sangers scoured the country for roots, and dealers made and lost fortunes on ginseng sales. The price is still high, and while some ginseng is being brought to dealers from Illinois, Missouri, West Virginia, and Kentucky, the bulk now comes from North Carolina, Tennessee, and Georgia....

Buck Carver claims that there are lots of places back in the woods where people have set out berries, and then either moved away or forgotten about them. They're there now for anyone to find. "Lord, there's patches of it planted back in them woods that people have planted in unsuspecting places [and never gone back to].

"Nearly everyone hunts on north ground in dark coves, you know, and lots of times a feller plants it back, he'll plant it on south ground. That's how come it's in Laney Cove there on Kelly's Creek.

"In 1937, we was making whiskey up there at the east end of them cliffs in what was called 'Stillhouse Cove,' and I come down there one day to see about the beer and see how near ready to run it was, and I dug several roots and got a good pocket of berries, and I went right through the Gap-Stillhouse Cove Gap-between Kelly's Creek and Mud Creek and down in the head of Laney Cove there-some good dark rich earth there, and walnuts growing in that earth too. So I crawled off in down below the road and reached up and transplanted them roots that I dug up and planted out that bunch of berries. And 
I checked on it pretty good there for several years, and it was coming along fine. And then I forgot it.

"About twelve years ago, I was making liquor over on Kelly's Creek and stumbled onto the durn stuff walking out the road one day. And I thought, 'Well, good God Almighty, what in the world are you a'doing here?' Big old stalk, you know. Big ball of red berries. And another step, another big one or two. And, 'Oh, yeah. Heck, yeah. I remember now. I planted you here!'

"So I dug a root or two-I didn't try to dig it for market [but] I ought to have-and I forgot it again then.

"About three or four years ago, one of my wife's son-inlaws said something about that patch of sang over there-did I know it was there. I says, 'I ought to know its there. I planted the durn stuff. And I went over there that fall to dig some of it and put in my garden here, and some feller had been in there just ahead of us and he'd dug all the big pretty sang they was there that he could find. And there' $d$ be the tops down on the ground, and big balls of berries. He'd never planted the durn berries back.

"Well, sir, that made me so durn mad I couldn't hardly see. I gathered every durn berry, and went to digging the little stuff then. Dug every durn thing I could find and brought it on over here and transplanted it in the garden.

"But now it don't all come up every year. I went back over there for two or three falls and found more. You can't get it all. I don't care how much - that Raven Rock Mountain there has been sanged to death as far back as I can remember. When I was eight years old, I went to digging sang on that mountain, and I've dug it off and on ever since, and they's still some there that ain't been found. I went up there this fall for a little while one day and found several roots and brought them and the berries in here and planted them in that garden."

"The biggest one I ever found," said Lawton Brooks, "was a five-prong bunch. Had the biggest root on it that I ever saw on one. [The plant] was at least up to my waist. I was 
a'standing, and I didn't know too much about it then. My wife's brother, he knows it, and he was letting me help him look for some. And he was digging it. He gave me a top to go by, and I was a'looking at the top and then a'looking to see if I could see anything like it. There ain't nothing else like it if you ever get used to it. Now I can find it. I can spot it just anywhere. Anyway, I was standing there, and there was a big old wad of berries as big as my fist there, a'sticking right up by my side, and I commenced hollering for him, and he come up there and said that was the biggest bunch he ever seen. So he dug it for me. I let him get it out. He was afeared I'd break it. So he dug it for me and I took it down there to the store, and that old man gave me a dollar and a half for it. Now that one root would bring a man ten or fifteen dollars because it's about sixty-five dollars a pound this year. It's higher than it's been a'being.

"Now as good a patch as ever I got into was that one that I found over in North Carolina. I got about forty-eight dollars worth that I dug and I wasn't over two hours. That's as good a patch of wild as ever I found in one place, and I didn't cover no territory. I didn't dig any further than from here to that filling station out yonder [about a hundred yards]. I just went backwards and forwards across the holler for a little piece, and I went up next to where the cliff was, and then I looked back down and I'd missed some and I went up, found some, and I went back down, and I come out. There might have been more below than there was above, but I ain't been back. But hadn't a'been nobody there in years digging no sang there. They'd a'been sure-they couldn't a kept from digging a whole lot in there. And I ain't been back. That's the reason I been wanting to go back so bad now. If I could get back in that place over there now and take my time and spend a couple of days over there, I could get a pile of that blasted stuff 'cause I know some places over there-them old hollers I used to hunt in when I was an old boy and lived there-I hunted in there all the time. I know where them old hollers is. I could get in there and I could find some ginseng. 
"I like to hunt it, myself. It's interesting. You get to hunting for it, it's interesting, boys. You just take a liking to it. Same way by bee hunting. I like to bee hunt. I ain't got no use for them when I find them, but I just like to find the bee trees. I know where four or five bee trees is now. But I wouldn't be stung for all of them. I'm afraid of them cussed things. They run me crazy!

"But that sang's turning yellow right now. The berries are ripe right now on it. I ain't felt like it or I'd be going. Right now's the best time. Yes, sir. The berries are red as they can be. There's people in the woods today somewhere' $r$ ' nother hunting it like the devil right now, I'll bet you. I've talked to several said they've been out. They go and camp out-stay a week at a time back in the woods and just do nothing but get up every morning and start again. Hunt a new territory every time. But I can't climb the mountains like I used to or I'd be right out there with them. I get out of breath too quick. But if I had the air, I'd be right out there with them, climbing around them rough places."

If ginseng is getting scarcer in the mountains, and it seems to be, it still hasn't diminished the number of people who hunt for it. They all have their stories-and their dreams. As Wallace Moore said, "One day I dug a big haverpoke full out of each of my beds and then didn't dig at all. Boy, that's a pretty sight to see where it's out like that. Or run into it. Walk up and see big wads of berries just scattered all over the side of the hill and in the holler. Well, I reckon it's about every sang hunter's dream-everybody that's ever dug the sang or fools around with it any-is always a'looking for a patch where he can dig maybe two, three hours, three, four hours, or a half a day in one patch. Everybody you see: 'Boy, if I could just find a patch where I could dig a half a day, I'd be all right!'

"But them patches are scattered." 
244 Contemporary Authors Search for a Usable Past

\section{Ginseng}

1. What medicinal qualities does ginseng have?

2. Why has the price of ginseng risen?

3. Explain how a new patch of ginseng is started.

4. The natural resources of Appalachia are its wealth. What are the most important natural resources in your area? 


\section{BERNARD STALLARD (1921-1986)}

Bernard Stallard taught in high schools and colleges in Kentucky and Florida and then spent several years as a social worker. At age 16 he published a poem about the Appalachians. While at Lincoln Memorial University, he was the first winner of the Ross Carter Memorial Award given for creative writing. His work also appeared in Reveille, an anthology published by Barnes and Noble. In 1978 Stallard was elected a fellow by The International Academy of Poets, Cambridge, England.

In addition to publishing articles and poetry in various periodicals, Stallard published a book of two hundred sonnets entitled Appalachian Summer. The collection was praised by Jesse Stuart, Kentucky's Poet Laureate. In 1977 Stallard wrote an outdoor drama, Cumberland Gap, and presented it to Lincoln Memorial University. The drama is as yet unproduced, but it inspired a verse narrative The Witch of Cumberland Gap.

Sensitively homespun, Stallard's work has a simplicity native to the rugged life it describes. "The Writing Spider" describes one of hundreds of old superstitions. 
246 Contemporary Authors Search for a Usable Past

\section{The Writing Spider}

The spider had hung out his wicked snare Up in a corner, near the cellar door, And my small brother told me to beware, That dreadful evil might be well in store: "Don't ever let that spider see your teeth, "Cause if you do," he cautioned anxiously, "Within a week or so you'll have a wreath Laid on your coffin that says R.I.P.! That spider is a writing spider there And, on his web, he'll write out all your name. So, you just smile at him if you don't care And you'll just die, and I won't be to blame!" Long following that warning, darkly stressed, I passed the cellar with my lips compressed.

\section{Writing Spider}

1. What superstition related to spiders do you find in this poem?

2. What does R.I.P. mean?

3 What does the poem suggest about the power of superstition and the impressionablility of a child? 
ED CABBELL 247

\section{EDWARD CABBELL (1946- )}

Writing poetry is just one of many interests of Ed Cabbell. This native of the West Virginia coalfields has been a pioneer in studying the experience of blacks in the Appalachian region.

After graduation from Concord College in West Virginia, Cabbell became the first black to receive an advanced degree in Appalachian studies at Appalachian State University. His master's thesis Blacks in Appalachia was published in 1985 by the University of Kentucky, co-edited by Cabbell and William $\mathrm{H}$. Turner. He created the John Henry Memorial Foundation, which focuses interest on the contributions of blacks to the life of the region.

This poem reflects an old man's condensed memories of life in the mountains, a world that is now lost to him.

\section{Appalachia: An Old Man's Dream Deferred}

As I ride the mountain curves

That make one mile ten

And my going greets my coming

I reminisce my past days

In the mountains of Appalachia.

I recall my five day weeks 
Among the diamonds-

That glisten and reflect

The sweat of my brow

And make me proud

Of my aches and pains

And silicosis and black lung

And John L. Lewis and the pension.

I recall my buddies

And slate falls and explosions

And union dues and company doctors

And script money and company stores

And friendly coal camp houses

Where smoke spirals from chimneys

And meets the tipple dust

Causing an excess that returns upon us,

my wife and kids and other families,

Causing us to cuss and fuss

and scrub with lye soap

In zinc tubs filled with hydrant water

Boiled in the big tea kettle on the cook stove

That stands near the kitchen cabinet and breakfast set.

I recall the Saturday night balls

Or fights and brawls

And women and liquor and cards

And fish fries and barbeques

And wiener roasts and excursions

And ball games-

All kinds of Saturday fun

That ends in Sunday School and Church

And occasional revivals

And preachers and deacons

And brothers and sisters

And prayers and collection plates

And rallies and homecomings.

I recall the bare beauty

of stripped mountains

That belch black diamonds 
And choke as we crawl inside

To retrieve what is left

Leaving a gully that fills

With leeched water

For children to swim and drown every summer.

I recall the shanties

And the houses of bosses

And homes of superintendents

And spring rains, and fall winds

And winter snows and summer sunshines

That bring new faces to the hills every year

And Christmas and Easter

And the Fourth of July

And fishing and hunting seasons

And walks in the mountains

And P.T.A. meetings and lodge meetings

And trips to the county seat

And funerals and birthdays

And other memories that practically

Bring to me tears.

But as I ride the curves of my homeland

I must view my dreams

For she is empty and dried and dismal

And her misery hangs heavy in the air of her discontent

I reach out to touch her but find her vanished-

An old man's dream deferred. 
250 Contemporary Authors Search for a Usable Past

\section{Appalachia: An Old Man's Dream Deferred}

1. What was the speaker's occupation?

2. The poet paints certain scenes of his life, calls up certain memories, simply by making lists of things. What are some of the memories "listed" in the poem?

3. What feelings are expressed in the last six lines?

4. Do you think the poet is expressing overly romantic or sentimental attitudes in his remembrances of the Appalachia of the past? Why or why not? 
JIM WAYNE MILLER (1936- ）

A native of western North Carolina, Jim Wayne Miller earned his undergraduate degree at Berea College in Kentucky. He continued his studies at Vanderbilt and received his Ph.D. in both German and American literature in 1965. While at Vanderbilt, Miller studied under Fugitive poet Donald Davidson.

At present, Dr. Miller is a professor of German language and literature at Western Kentucky University. His stature and reputation as a poet have grown steadily since his first volume of poetry, Copperhead Cane, was published in 1964. His other collections are Dialogue With A Dead Man, The Mountains Have Come Closer, Vein of Words, and Nostalgia for 70 . He received the Thomas Wolfe Award in 1985 for The Mountains Have Come Closer. 
252 Contemporary Authors Search for a Usable Past

\section{Beginning, Ending}

Once he said his earliest recollection

was of waking on a cold winter morning in their cabin on Newfound Creek and hearing his father picking Tom Dooley on a banjo while meat fried on the stove and his mother ground morning coffee on the little mill.

That early recollection was of hungerfor the fried meat and biscuit, and hunger too for the old songs picked on a curly-walnut banjo.

A part of him never went back any further than that morning of fried meat, coffee, and a ballad.

For in his darkest moods-the time a hailstorm cut his burley tobacco to shreds in half an hour-he'd go back to the music he'd given up for months, take his guitar down, walk out somewhere, and try to sing and play the misery out of his soul.

When he worked in the woods timbering, or sawmilled, plowed all day or worked at road construction, his hands hard as shoe leather, he'd swear he was no more than broad back and heavy arms inside a sweat-soaked shirt. But when he sang and played, sometimes he grew as light as air, and now and then he thought he could remember the Scottish border, the Ulster linen trade, a county fair where drummers from the ships signed up people for the colonies.

He could see something moving through the flesh of generations, playing like light on always moving water. He saw himself in the cheekbone of his father. He looked out of his daughter's eyes, glimpsed himself in the gait of his growing boys. 
Once in September, puzzled by coming so wide awake so long before day, he stepped out into a morning soft on his face as spiderwebs, full of a dream of some boy himself waking to fried meat and biscuit, leaving home in warm September darkness for a far-off school.

He started out thinking ridge-to-ridge, thinking he lived nowhere but in his skin. Thinking ocean-to-ocean now, he wasn't sure where he began, where he would ever end.

\section{Beginning, Ending}

1. What effect does music have on the poet?

2. In the fifth stanza the poet talks of stepping out into the morning soft as a spider web. What image does this bring to mind?

3. Although the poet is not sure where he will begin and end, the poem links him to beginning and ending generations. Find evidence of this. 
254 Contemporary Authors Search for a Usable Past

\section{JEFF DANIEL MARION (1940- ）}

In 1975, Jeff Daniel Marion founded The Small Farm, a little magazine that featured poetry, criticism, and reviews by those who shared Marion's sense of place. Only twelve issues were published. The Small Farm and Marion's own works Out in the Country, Back Home (1976) and Tight Lines (1981) have earned him recognition as Appalachia's official Pastoral Poet. His poetry offers keen observations and powerful imagery. It paints memorable portraits of the land and people in his east Tennessee home.

Marion earned his undergraduate and graduate degrees in English at the University of Tennessee and has continued his studies at the University of Southern Mississippi and the University of Alabama. He is an associate professor at CarsonNewman College in Jefferson City, Tennessee, and editor and publisher of Mill Springs Press in New Market, Tennessee. 


\section{Ebbing \& Flowing Spring}

Coming back you almost expect to find the dipper gourd hung there by the latch. Matilda always kept it hidden inside the white-washed shed, now a springhouse of the cool darkness \& two rusting milk cans.

"Dip and drink," she'd say,

"It's best when the water is rising."

A coldness slowly cradled in the mottled gourd.

Hourly some secret clock spilled its time in water, rising momentarily only to ebb back into trickle.

You waited while

Matilda's stories flowed back, seeds \& seasons, names \& signs, almanac of all her days.

How her great-great grandfather claimed this land, gift of a Cherokee chief who called it "spring of many risings."

Moons \& years \& generations \& now Matilda alone.

You listen.

It's a quiet beginning but before you know it the water's up \& around you flowing by.

You reach for the dipper that's gone, then remember to use your hands as a cup for the cold that aches \& lingers. 
256 Contemporary Authors Search for a Usable Past

This is what you have come for.

Drink.

\section{Ebbing \& Flowing Spring}

1. The image of water is found throughout this poem. Find words that relate to water. The word drink is used twice. Could it refer to drinking memories as well as water? What are some of the memories the poet mentions?

2. How does the title "Ebbing \& Flowing Spring" relate to the main idea of the poem? 


\section{FRED CHAPPELL (1936- )}

Fred Chappell has received praise, recognition, and critical acclaim, especially since the prestigious Bollinger Prize for Poetry was awarded to him in 1984 for his collection Midquest.

A graduate of Duke University, Chappell was born in Canton, North Carolina, to a family in the furniture business. He is a prolific writer with poetry, short stories, novels, reviews, and essays to his credit. His publications include his latest novel I Am One of You Forever and most recent book of poetry Source. Other titles by Chappell include Moments of Light (short stories) and The World Between The Eyes and The Castle Tsingal (poetry). He currently teaches at the University of North Carolina at Greensboro.

\section{My Grandmother Washes Her Vessels}

In the white-washed medical-smelling milkhouse She wrestled clanging steel; grumbled and trembled, Hoisting the twenty-gallon cans to the ledge Of the spring-run (six by three, a concrete grave Of slow water). Before she toppled them inDented armored soldiers booming in painShe stopped to rest, brushing a streak of damp 
Hair back, white as underbark. She sighed.

"I ain't strong enough no more to heft these things.

I could now and then wish for a man

Or two...Or maybe not. More trouble, likely, Than what their rations will get them to do."

The August six-o' clock sunlight struck a wry Oblong on the north wall. Yellow light entering This bone-white milkhouse recharged itself white, Seeped pristine into the dozen strainer cloths Drying overhead.

"Don't you like men?"

Her hand hid the corner of her childlike grin Where she'd dropped her upper plate and left a gap. "Depends on the use you want them for," she said. "Some things they're good at, some they oughtn't touch."

"Wasn't Grandaddy a good carpenter?"

She nodded absentminded. "He was fine. Built churches, houses, barns in seven counties. Built the old trout hatchery on Balsam... Here. Give me a hand."

We lifted down Gently a can and held it till it drowned. Gushed out of its headless neck a musky clabber Whitening water like a bedsheet ghost. I thought, Here spills the soldier's spirit out; If I could drink a sip I'd know excitements He has known; travails, battles, tourneys, A short life fluttering with pennants.

She grabbed 
A frazzly long-handled brush and scrubbed his innards

Out. Dun flakes of dried milk floated up,

Streamed drainward. In his trachea water sucked

Obscenely, graying like a storm-sky.

"You never told me how you met."

She straightened,

Rubbed the base of her spine with a dripping hand.

"Can't recollect. Some things, you know, just seem

To go clear from your mind. Probably

He spotted me at prayer meeting, or it could

Have been a barn-raising. That was the way

We did things then. Not like now, with the men

All hours cavorting up and down in cars."

Again she smiled. I might have sworn she winked.

"But what do you remember?"

"Oh, lots of things.

About all an old woman is good for

Is remembering....But getting married to Frank

Wasn't the beginning of my life.

I'd taught school up Greasy Branch since I

Was seventeen. And I took the first census

Ever in Madison County. You can't see

It now, but there was a flock of young men come

Knocking on my door. If $I^{\prime} \mathrm{d}$ a mind

I could have danced six nights of the week."

We tugged and cleaned can out, upended it To dry on the worn oak ledge, and pushed the other Belching in. Slowly it filled and sank.

"Of course, it wasn't hard to pick Frank out, The straightest-standing man I ever saw. 
Had a waxed moustache and a chestnut mare.

Before I'd give my say I made him cut

That moustache off. I didn't relish kissing

A briar patch. He laughed when I said that,

Went home and shaved....It wasn't the picking and saying

That caused me ponder, though. Getting married-

In church-in front of people-for good and all:

It makes you pause. Here I was twenty-eight,

Strong and healthy, not one day sick since I

Was born. What cause would I have to be waiting

On a man?"

Suddenly she sat on the spring-run edge

And stared bewildered at empty air, murmuring.

"I never said this to a soul, I don't

Know why...I told my papa,'Please hitch me

The buggy Sunday noon. I can drive

Myself to my own wedding.' That's what I did,

I drove myself. A clear June day as cool

As April, and I came to where we used to ford

Laurel River a little above Coleman's mill,

And I stopped the horse and I thought and thought.

If I cross this river I won't turn back. I'll join

To that blue-eyed man as long as I've got breath.

There won't be nothing I can feel alone

About again. My heart came to my throat.

I suppose I must have wept. And then I heard

A yellowhammer in a willow tree

Just singing out, ringing like a dance-fiddle

Over the gurgly river-sound, just singing

To make the whole world hush to listen to him.

And then my tears stopped dropping down, and I touched

Nellie with the whip, and we crossed over." 


\section{My Grandmother Washes Her Vessels}

1. Who is the person asking questions in this poem?

2. Personification is a figurative device in which human qualities are given to something nonhuman. Find examples of personification in the first few stanzas of this poem.

3. Find evidence of the grandmother's self-reliance and independent spirit.

4. In the grandmother's recollections she shows a hesitancy towards getting married. Why is this so? Why does she finally "cross the river"? 
262 Contemporary Authors Search for a Usable Past

\section{MARILOU AWIAKTA (1936- )}

Marilou Awiakta, a seventh-generation Appalachian with Cherokee heritage, was born in Knoxville, Tennessee. At the age of nine she moved to Oak Ridge but returned to Knoxville to attend the University of Tennessee. After graduation, with a degree in French and English, she worked as a teacher and translator. Her articles, poetry, and fiction appear regularly in national magazines and have won many state and regional prizes, including the Jesse Hill Ford Award for Poetry in 1972. 


\section{Where Mountain and Atom Meet}

Ancient haze lies on the mountain smoke-blue, strange and still a presence that eludes the mind and moves through a deeper kind of knowing. It is nature's breath and morean aura from the great I Am that gathers to its own spirits that have gone before.

Deep below the valley waters eerie and hid from view the atom splits without a sound its only trace a fine blue glow rising from the fissioned whole and at its core power that commands the will quiet that strikes the soul, "Be still and know...I Am."

\section{Where Mountain and Atom Meet}

1. The phrase "I Am" is used twice in the poem. To what does it refer in each stanza?

2. Compare and contrast the mountain and the atom. Can you find similarities in two things so vastly different in size? 


\section{COMPOSITION TOPICS}

1. Like the writers in this section who cast a backward glance into their pasts, look back into your own life and select a treasured or unforgettable memory. Write a composition describing the experience in detail to show why it was important to you. You may want to include this paper in your family scrapbook.

2. Write a composition about the characters in the literary selections that you have read who search for their pasts. Explain what they find in their pasts that helps them understand themselves.

\section{ACTIVITIES}

The chapters you now add to your book will tell about customs and traditions in your family.

If your family sings, collect lyrics to their songs. List any family members who play instruments and the name of the instrument. Make this the music history of your family. Illustrate with photographs.

Families are sometimes known for their good cooks. Collect your favorite recipes from the cooks in your family and record them here.

Families also celebrate together. Select two family holidays and write about them answering the following questions:

1. What is the holiday celebration?

2. Who attends? Name them.

3. Where do you celebrate? 
4. What do you eat and drink?

5. What do you do?

6. Describe any special decoration.

7. If the celebration has changed during your lifetime, describe the change and what caused it. For example, when you were younger you may have cut down a Christmas tree on your grandfather's farm. Now that your grandfather is no longer living or now that you live in the city, you may buy an artificial one which you use each year. 
This page intentionally left blank 
PART II

The Present 
This page intentionally left blank 


\section{CHAPTER 4 \\ How America \\ Came to the Mountains}

The remainder of this book will focus on the present. We will examine some contemporary writings that reflect the concerns of the Appalachian community and its writers today.

The Twentieth Century has brought tremendous change to the region. Educational reform, an expanded highway system, better health care, and a higher standard of living have improved the lives of most people in the mountains. Various governmental and private institutions have provided funds and expertise for these visible improvements. Chapter Four directs attention to the impact these institutions have had on Appalachian life and to the reaction of some writers to this change.

The title for this chapter comes from a poem by Jim Wayne Miller in The Mountains Have Come Closer. He explains how shocking it was when mainstream America roared into the mountains bringing manufactured goods, bulldozers, 
highways, fancy cars, singing commercials, and designer jeans. He uses satire to point out how mountain life has seemed to change quickly. Actually, the winds of change had been blowing for some time.

Perhaps the most significant agent of change in the region has been the Tennessee Valley Authority. This governmental agency came to the Tennessee Valley to build a series of dams, control flooding, make the Tennessee River navigable for most of its six hundred miles, manufacture nitrates for explosives and fertilizer, reforest marginal land, conserve soil, provide for agricultural and industrial development, and supply hydroelectric power.

Primarily, TVA opened the way for the industrialization of the South. With cheap electricity available, northern factories began to move to the South and to employ local people. People accustomed to subsistence farming, barter, and a single cash crop began to earn regular incomes. Specifically, TVA led to the establishment of Oak Ridge as the home of the Manhattan Project and the atom bomb. These actions have affected practically every person in the region.

The Appalachian Regional Commission, another governmental organization, has also had an impact on Appalachia. Acting as a regional advocate in the Congress, the ARC has administered millions of federal dollars for highways, water and sewer services, vocational training, and schools in Appalachia.

One important non-governmental institution, the Highlander Research Center in New Market, Tennessee, is discussed in this chapter. It represents another kind of force that has influenced modern life in Appalachia. This is the force unleashed in the individual and community when a desire for change leads to action.

Leadership training at the Highlander Folk School gave some Appalachian people the skills to think and analyze and the courage to act. Myles Horton, its founder, and other leaders have trained many working-class adults to take responsibility for their lives and circumstances. 


\section{ALAN CHEUSE (1940- )}

Alan Cheuse was born in New Jersey and has been a writerin-residence at the University of Tennessee, the University of the South, and the University of Michigan at Ann Arbor. He is also on the summer faculty at Bennington College in Vermont.

Cheuse, who received his $\mathrm{Ph}$.D. from Rutgers University in comparative literature, has published one novel which is based on the life of American journalist John Reed. The stories and articles of Cheuse, including the one presented here, have been published in numerous periodicals and literary magazines. He also reviews books for the National Public Radio program All Things Considered.

This piece, written in celebration of the 50th anniversary of the Tennessee Valley Authority, describes how a federally crafted program built a network of dams which brought light to a dark valley of Appalachia.

\section{Tripping The Lights Fantastic}

It is near the end of a Sunday in spring, and I've driven up here into the foothills of the Cumberlands to watch a small river valley fill up with night. Evening comes earlier in the tailwaters of the Norris Dam than it does to the city of Knoxville, 
say, thirty miles south, but already the street lamps have flashed on there, anticipating the darkness this little valley already knows quite well. Here you have only to glance upstream at the large blackened wall of cement that straddles the valley and then look down again directly and you'll feel as though you've lost minutes, not seconds, of fleeting light. My eyes flit back and forth in search of fishermen, back and forth, back and forth. There's one. There's another, his slicker dark against waters already nearly blending with the color of the dam, the bleak wall with its striations of white where fog tears off from big cottony bunches above the rim and slips down its face.

A light drizzle sifts onto the watcher and the waters, the fishermen and the trees, lovely straight stands of pine and walnut, darkening leaves, needles, bark. Blackness brims up now from the river bed as though sky and water had become inverted and the sun had slipped away beyond the nether shore and rolled along behind the rocks and trees.

The fishermen have drowned in darkness, even the river has drowned, and the space between where I stand and what I remember of the other shore becomes an unbroken stretch of obscurity. The fog has disappeared, and I am surrounded by darkness. A city boy born and bred, I find it amazing that people could spend half their lives in such blackness as this.

The wind quiets down. I can hear at last the faint hum of the power station and remember that there is, in fact, light abundant for the valley dwellers now. Fifty years ago this month the region began to come out of the dark. After long discussions with forester-conservationist Gifford Pinchot, for whom a river was a single unit from its tributaries until it emptied into the sea, after an immersion in the progressive vision of the senator from the Great Plains, George W. Norris of Nebraska, and aided by delegates from the 40,910-squaremile watershed of the Tennessee River, President Franklin D. Roosevelt in the spring of 1933 urged Congress to create the Tennessee Valley Authority.

In fact, though no plaque marks the place, Roosevelt stood 
on this same bank of the upper Clinch River in the autumn of 1932, having, at Norris' suggestion, stopped here on a drive up to Washington from his retreat in Warm Springs, Georgia, just after he won the presidential election. Here he looked upon the waters and said, "Let there be dams," and there was and still is light, light abundant, light overflowing, flooding the Tennessee Valley as only the river once did. And he returned, accompanied by Eleanor Roosevelt, to witness the construction of the dam named after Norris, several years later. He may have noticed that his wife, against all warnings, took a ride in the cable car strung between the two bluffs that was the simple laborer's way of hauling himself to the upper stories of the newly rising dam....

In 1929 Major General Lytle Brown, as head of the Corps of Engineers, produced a 732-page survey of the Tennessee Valley entitled Tennessee River and Its Tributaries. After that, advocates of a development plan for the region that would integrate navigation, flood control, hydroelectric power production, soil conservation, fertilizer production, and forestry came armed with all the basic information they needed to launch the project. With the election of Roosevelt, whose mandate was to improve the depressed social and economic conditions of the staggering nation, they finally had the political power they needed. Before Christmas of 1932, Roosevelt made his stopover at Cove's Creek on the Clinch River, one of the main tributaries of the Tennessee. He was convinced that the United States was ripe for development that tied together industry and agriculture and flood prevention and was persuaded that the Tennessee watershed, rich in potential but miserably underdeveloped, would be the best place to institute a model of such planning.

The poor, ill-clad, ill-housed, ill-fed tenant farmer population of Tennessee knew little of such ventures. Waking by lamplight; farming with crude implements and methods not only outmoded but destructive; living on a diet that treated them as badly as they treated the soil; suffering primitive sanitary conditions; because of their lack of electricity, of 
phonographs and radios or both, estranged from the mainstream of American society; badly educated; shivering in winter; sweltering in summer; attacked by parasites; plagued by malaria-this was the plight of the famous men (and women) James Agee asked us to praise, the "some there be which have no memorial," as he put it in his epochal book about tenant farmer life in the South.

The landowners were not much better off, enjoying the certainties of the primitive Baptist religion handed down over generations and filling their relative isolation with traditional music, song, and dance, but paying for their independence and cultural solitude by enduring without assistance rain, flood, drought, erosion, and pestilence that seemed sometimes as fierce as any out of biblical times....

The water was rising. And so was the first of the TVA dams. And more than two dozen more dams would rise before the TVA had completed its network of flood control and hydroelectric production sites. Two dozen dams, including the majestic 480-foot Fontana Dam in the wild woods of the Great Smoky Mountains just east of the Tennessee-North Carolina border-massive Fontana, hidden in the wilderness like some ruin out of Toltec or Mayan civilization. The names of the rivers that bear these dams like modern bracelets on the arms of uncivilized beauties-the Powell, the Holston, the Nolichucky, the French Broad, the Little Tennessee, the Hiwassee-the names of the dams themselves that grew upon these tributaries and then along the course of the Tennessee itself westward to Paducah the Watauga, Douglas, Cherokee, Fort Loudoun, Calderwood, Cheoah, Santeelah, Hiwassee, Chatuge, Blue Ridge, Ocoee, and Chickamauga, Watts Bar, Guntersville, Wheeler, Wilson, and others,-these names make up a litany half Indian, half Blue Grass. What is it about a high dam that, unlike even the tallest of skyscrapers, makes a person wonder about the prowess of modern architecture and engineering? Perhaps because a skyscraper stops nothing but air and a dam holds back the possibility of floods of biblical proportion, be- 
cause a dam can generate power to brighten entire valleys where once only lamplight held back dark.

\section{Tripping the Lights Fantastic}

1. In what ways other than in the production of electricity did TVA benefit the areas it supplied?

2. What promise had Roosevelt made to the people before his election to the presidency? Did his support of TVA help carry out this promise? 


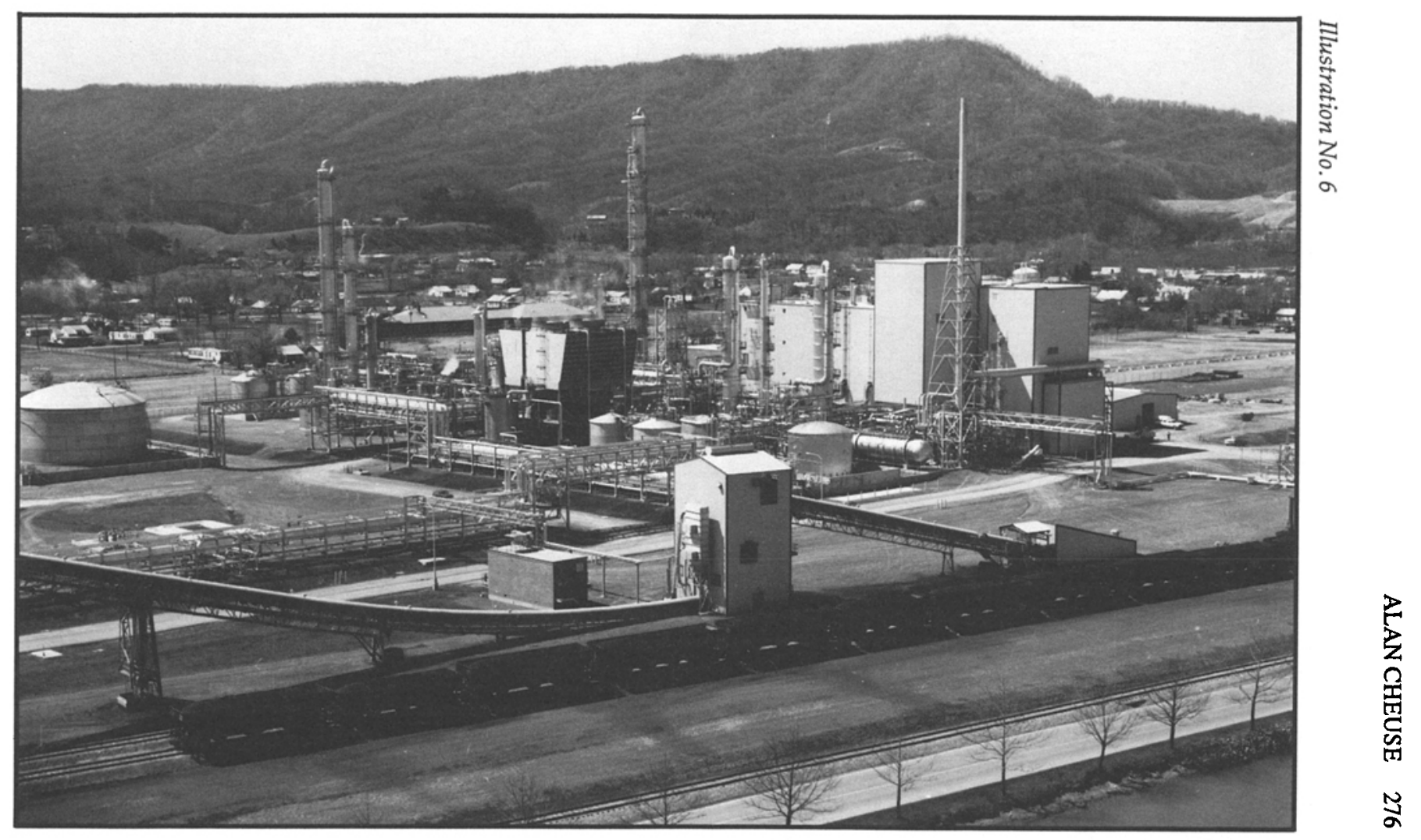




\section{VICTOR M. DEPTA (1939 - )}

Victor Depta, associate professor of English at the University of Tennessee at Martin, is a native of West Virginia. He received a B.A. degree from Marshall University in his home state before earning his M.A. degree from San Francisco State College and his Ph.D. from Ohio University.

After nearly twenty-five years away from Appalachia and after schooling in and out of the region, he claims to be a "proletarian hillbilly." Besides poems in numerous magazines, he also has two books of poetry, The Creek and The House.

This poem "TVA" looks back and suggests that the past now lies buried under the flood waters created by that agency. 
TVA

Do you know, I said to Charlene, in Tarpon Springs aunt Ruby and uncle Lucke are grocery bags? Death eats out of them and litters them on the shore. They sit there all day knowing they're retired. Really.

If my face weren't a lunch bag I could tell them that they ought to come home no matter if their children do say How wonderful mommy and daddy are sitting down here in Florida like hydropathic mummies.

Maybe I could put a hand over their mouths and eyes and tell them I remember their warming a pillow in front of the fireplace for me and giving me a bed, tell them I still need them. I mean what am I going to do about getting married. I need some advice.

But maybe they know something I don't, maybe they're sick of it, may be nothing real is worth coming home to. By the time they got here everything would already be buried, probably under a water skier.

TVA

1. Is this poem happy or gloomy. Why?

2. The poet uses metaphors to describe Aunt Ruby, Uncle Lucke, and the speaker in the poem. Explain the metaphors. 


\section{MARILOU AWIAKTA (1936 - )}

Marilou Awiakta, a seventh-generation Appalachian with Cherokee heritage, was born in Knoxville, Tennessee. At the age of nine she moved to Oak Ridge but returned to Knoxville to attend the University of Tennessee. After graduation, with a degree in French and English, she worked as a teacher and translator. Her articles, poetry, and fiction appear in Ms. and Southern Exposure magazines. She has won many state and regional prizes, including the Jesse Hill Ford Award for Poetry in 1972. The United States Information Agency chose two of her books for its 1986 Global Tour of American Writers.

This poem from Abiding Appalachia: Where Mountain and Atom Meet focuses on the change in the city of Oak Ridge, Tennessee, as the "atomic city" developed out of a rural landscape. 


\section{Genesis}

Settlers sowed their seed.

Then their sons took the plow and in their turn grew old. And the mountains abided, steeped in mist.

But in the deep was a quickening of light, a freshening of wind...

And in 1942, as fall leaves embered down toward winter,

New ground was turned near Black Oak Ridge.

The natives pricked their ears.

These descendants of old pioneers

Lifted their heads to scent the wind-

A frontier was a borning.

Many had to pack up hearth and home and go.

But others joined the energy that flowed toward Black Oak

Ridge

as to a great magnetic power:

Thousands of people streamed in.

Bulldozers scraped and moved the earth.

Factories rose in valleys like Bear Creek

and houses in droves sprang up among the trees

and strung out in the lees of ridges.

A great city soon lay concealed among the hills.

Why it had come no one knew.

But its energy was a strong and constant hum,

a new vibration, changing rhythms everywhere. .

It charged the air in Knoxville, where we lived

and when I saw my parents lift their heads,

I lifted my head too, for even at seven

I knew something was stirring in our blood, something that for years had drawn the family along frontiers from Virginia to West Virginia, on to Kentucky and Tennessee. And now, a few miles away, we had a new frontier.

Daddy went first, in '43-leaving at dawn, coming home at dark

and saying nothing of his work except, "It's at Y-12, in Bear Creek Valley." 
The mystery deepened.

The hum grew stronger.

And I longed to go.

Oak Ridge had a magic sound-

They said bulldozers could take down a hill before your eyes

and houses sized by alphabet came precut

and boxed, like blocks,

so builders could put up hundreds at a time.

And they made walks of boards and streets of dirt

(mud, if it rained)

and a chain-link fence around it all to keep the secret.

But the woods sounded best to me.

My mind went to them right away...

to wade in creeks and rest in cool deep shadows,

watching light sift through the trees

and hoping Little Deer might come.

In the Smokies I'd often felt him near and I knew he'd roam the foothills too.

Woods were best. And if the frontier grew too strange my mountains would abide unchanged, old and wise and comforting.

So I kept listening to the hum, and longing. . . Mother said we'd go someday, in the fullness of time And when I was nine the fullness came, exploding in a mushroom cloud that shook the earth. 
282 How America Came to the Mountains

\section{Genesis}

1. In the phrase "a frontier a-borning," to what does frontier refer? This word is used several times in the poem. Does the meaning change any with each use? Explain.

2. Referring to the great city Oak Ridge, the poet writes, "But its energy was a strong and constant hum, a new vibration changing rhythms everywhere." Discuss the ways that rhythms everywhere have changed since we split the atom.

3. In the midst of all the change, what remains constant according to the poet? Do you agree? Is there really anything that remains constant? 
JOHN EHLE 283

\section{JOHN EHLE (1925 - )}

Born in Asheville, North Carolina, and educated at the University of North Carolina, John Ehle has been an assistant professor in the Communications Center of his alma mater and a visiting professor at New York University. He has served as a special assistant to the governor of North Carolina and as a board member of the Governor's School and the Creative Arts Foundation in his native state.

The author of both novels and biographies, he is also the author of twenty-six plays in an NBC series American Adventure, broadcast by Radio Free Europe, Voice of America, and the Armed Forces Network.

The following excerpt from his novel The Road describes Weatherby Wright, Chief Engineer of the North Carolina Railroad Company, who is committed to extending the tracks over Sow Mountain. The story gives us insight into the dangers for those who first built roads through rough mountain terrain.

\section{From The Road}

The winter, which had started early this year, became warm in mid-December, the official start of winter itself. The crevices lost the pools of snow they had protected, and the earth released much of the water it had held and became soggy 
and treacherous to men working the fills and tunnel. A few small flowers began to bloom near the office at Henry Station.

Weatherby, on the second Friday in December, had hoped to awaken early. He wanted to go down to Henry Station with Cumberland and talk with an official from Raleigh who was coming in on the train, but he got delayed at the tunnel with one thing and another; then just as the two of them were ready to leave, word came from Babcock Station that the east fill on Long Bridge had started to creep. Weatherby told Cumberland to go ahead to Henry, that he would detour by way of Babcock and study that situation, and join him later.

He had gone about a mile or a mile and a half into the woods when a mountain boy came running after him. "They had a wounded man happen," he called as he approached. "Up at the tunnels they blasted a man."

"Not Moses?"

"No. I don't know just who, but they want you."

Weatherby found a dry rock and sat down. He put his elbows on his knees and leaned forward, frowning at the dripping, drooling earth. The mountain boy crouched nearby, staring at him quizzically.

"You put your shirt on backwards this morning, didn't you, boy?" Weatherby said kindly.

"It was dark when I come to wash and dress."

He saw three men down on the mountain a ways, walking along with a mule.

The boy said,"What do you aim to do?"

"I don't know yet," Weatherby said. "I have several critical things to do all at the same time." He took out his pipe and filled it. "Was the man bad hurt?"

"His back was busted."

"Is the doctor there?"

"No, sir, he's not found yet."

"What do they think I can do for him?"

The boy scrouged up his face. "Whenever anything happens, they allus send for you. The hurt man asked for you, too." "Well, I'm glad he did. Did the other men stop work?" 
"Yes, sir, while Esau mashed the holes at the heading." know?"

"What are those three men doing down there, do you

"That's them telegraph men aworking."

"They were working near the Gap yesterday. They have wire all over this mountain, and for what effect?"

"Yes, sir," the boy said. He crouched there, content to be near Weatherby, for he liked him and was honored to be with him. They sat there for a while, Weatherby smoking his pipe.

"Well, see here, boy," he said. "We have one fill creeping, and one wounded man, and one Raleigh official, each at a different station. Tell you what, you go on back to the tunnel and tell Babcock to handle the situation there and to keep the men at work."

"Yes, sir."

"I'd better go see about this fill. We could lose Long Bridge."

The boy left, and Weatherby went on down the trail.

As he approached a spot high over Mud Cut, his foot slipped and he fell. He grabbed a laurel trunk, but his hand failed to hold onto it, and he fell into a ten-foot ravine. It wasn't a dangerous fall, but he knew even as he landed that he had injured himself.

He lay there murmuring, exasperated with his poor fortune. He moved his right hand. It wasn't broken. He tried the other hand. That one was all right, too. He tried his right foot. He could move it. He tried his left foot. He couldn't move it at all.

He propped himself up on his elbows and saw with relief that there was no blood on his pants or on the ground. $\mathrm{He}$ looked around for pieces of wood that he might make leg splints from, and pulled himself across the ground toward a clump of laurel. He felt around under the laurel bushes, but found nothing usable there.

Of course, they would find him, he knew that. Those mountain boys were certain to find him. "Hey, you," he called suddenly. "Hey, up there," he called. Those three telegraph 
men might still be about somewhere. He cupped his hands to his mouth and shouted at the top of his voice. "Hey! Hey! Music man, come down here!"

He called many times, for well over an hour, before he began to admit to himself that nobody had sent out a search party to find him, that no one at the camp knew he was even lost. And they might not know for a day or so.

He looked down at his broken leg. There was blood there now, staining the snow.

He had matches in his pocket, but there were no dry twigs, so he was in for a cold night of it, he supposed, and he might as well do what he could to make the most of it. If he tried to walk, he would only rupture his leg all the more.

He began dragging himself to the edge of the ledge. Sometimes the mountain held pleasant surprises, as well as unpleasant ones. He pulled himself along, letting the left leg dangle behind him. He came to the edge of the ravine and saw below him a further drop of perhaps ten feet to another rock ledge; below that was yet another drop of ten feet to a place where the mountain's shoulder rolled more gradually downward.

He took hold of a laurel trunk and leaned over the edge of the ledge as far as he could. It appeared that there was a cave under there, or some indentation which would at least help protect him from the weather.

There was no way to get down there, except that one birch sapling might bend far enough to lower him to it. The maneuver was risky, but he did need to find shelter. He took hold of the sapling and began to inch out onto it. The sapling bent evenly as he lent his weight to it. He moved out a hand at a time.

He dropped, landing on his good leg and falling forward, cushioning the blow. He lay there, breathing deeply.

He looked behind him and saw the cave. At once he crawled toward it, inching his way along, his hands almost frozen by the snow. He could see beyond the dark mouth of the cave a dry spot where he could lie. The cave went quite a 
way into the ground beyond its narrow opening, and there was no beast inside, not that he could see. Everything was hospitable.

He pulled himself through the opening onto the dry floor and crept farther into the cave before he flopped on his belly and lay there listening to his heart and to his own breathing. The rock felt warm after the hours of lying on the wet ground. It was all right; he would be safe here until they found him.

The gang foremen at Babcock Station hadn't waited for Weatherby. When they saw that the embankment was still creeping, they put all their gangs to work throwing up a rock wall to hold it, and sent an emergency message to each of the other two stations, asking for convicts to help out. The messages left the impression that Weatherby was requesting the men, so each camp sent a gang of men under guard. About 250 men in all were put to work.

Everybody was worried about the Long Bridge, of course, and nobody had time to wonder where Weatherby was.

During the day the telegraph men walked their line and that night they began testing their signal. To everyone's surprise at the Tunnel Station, especially the director of the Western North Carolina Telegraph Company, the signal worked very well. When the clerk tapped the key, there did come a response. He tapped the signal for BabcockStation and was answered immediately; he tapped the signal for Henry Station and was answered, though somewhat less clearly.

"Send a message to Weatherby at Babcock," Babcock suggested.

The message was tapped out slowly by the clerk, who was no better at telegraphy than he needed to be, and who was surrounded by talking spectators, all of them excited.

In response came a few random noises, then the steady beat of the machine. The clerk followed it all as best he could. "Weatherby's not there," he said.

"Ask them how Long Bridge is," one of the men said.

The clerk began tapping out that question, but was interrupted by the clacking keys. The clerk wrote something out, 
then studied over what he had written. "Says it's not creeping," he said. "I don't know what that means."

"I know what it means," Babcock said. "Ask him where Weatherby is."

The clerk prepared to do so, but others of the group were more concerned about the bridge and wanted more information about that, so the clerk tapped out questions they originated, and Babcock retreated from the stuffy room and stood in the yard, confident that at any moment Weatherby would appear.

A guard came out of the office. "They say they're getting tired at the bridge."

"Are they going to be able to hold it?" Babcock said.

"They're going to build the wall through the night."

The guard swaggered toward the flophouse. There was quiet in the camp, except for the sound of water falling on the mountain. A wolf howled, then another. The pack was roaming tonight. The hungry pack was no doubt following every track that promised food, every footprint, every drop of blood on the ground.

Where was Weatherby? Babcock wondered. There was no need to worry about him, because he never needed concern from others; of all men, he was the most self-sufficient. Babcock didn't mean to worry about him, but he couldn't help wondering about not being able to locate him.

Men began pouring out of the office building. "The damn contraption broke," they said. Babcock went inside and watched the clerk fiddling with the instrument. Plover was helpless and despondent. He had known a few minutes of high exultation while the telegraph worked; he knew correspondingly low dejection now that it did not. "It's only the warm weather that bothers it," he said. "It's unseasonable to be so warm in December."

"You might check the line between here and Babcock. I'll walk part way with you," Babcock said.

"I'll wait till morning."

"Can you get Henry Station?" Babcock asked the clerk. 
"The line goes first to Babcock, so if that's out, there's no way to go down the mountain. Something's wrong between here and Babcock."

"Maybe the wolves are eating it," Babcock said.

"You work your tail off," Plover said, "and you keep having troubles along the way."

Abruptly the telegraph line began to crackle, and Plover jumped up in glee. "Ay, God, it works, it works agin!"

It was a message for Weatherby.

The clerk replied that Weatherby was not at the TunnelStation. A second message began. "Where is he?" That was all it said before the signal stopped and the line went dead again.

Perhaps some misadventure had befallen Weatherby, but the very thought made Babcock feel inadequate. It was inconsiderate to think that Weatherby would need help at all. If Weatherby were ever to need help, Babcock thought, he would plan the occasion so carefully that the help would be on its way before he needed it.

The idea struck him as being funny and he had to laugh, and when a guard asked him what was the matter, he said, "I was only thinking something might have happened to Weatherby," which he realized didn't explain his laughter at all well.

He sat down at Cumberland's desk and began to fidget with the inkwell. A mountain boy came to the door with a cup of coffee. "Come and set," Babock said.

The boy did so, and Babcock said, "In this soggy mush, you think it's too late to trail a man that went out of here this midmorning?"

"Might be."

"I think it might be, too."

He could send out a search party, but it was a mark against a man to be lost, or to have others say he was lost.

"Where's Mr. Weatherby at tonight?" the boy asked.

"I don't know yet," Babcock said. He didn't want to take charge, that was it. He didn't want the responsibility falling on him. He wanted to do what he was told to do; that was all 
he could confidently control, could manuever through. He was not a man of new actions, but a repeater of old ones. He was making a road, which was innovative, but he was not himself an innovator, and he just didn't know what to do.

Cumberland got back to the Tunnel Station early next morning. He had been down at Henry, he said, waiting for Weatherby. When he found out that Weatherby wasn't at the Tunnel Station and had never reached Babcock, either, he immediately called in the mountain boys who stayed there, about fourteen of them, and told them Weatherby was missing. "Can you find him?" he asked.

"We'll find him," one of them said simply.

"We'll find him, if he's out there," one boy said.

Weatherby had slept fitfully, his dreams filled with throbbing and troubled with the touch of a hand which kept moving over his injured leg. At one time in his delirium he had caught the hand and pushed it away, and for a time there had been nothing touching him at all.

He lay on his belly on the floor, his body aching from the rock bed, and from the cold, and from the wound, and from his fears, which were more acute now than before, He had never before considered his own death, but he knew the mountain world well enough to know he was caught in one of its conspiracies. Just as a spiderweb traps an insect or a laurel slick traps a wanderer, there were nets and traps for the mountain man, too.

In his mind was the thought, cyclically recurring , that the mountain knew he was there and had planned all this. He was himself a maker of plans, and he could recognize a plan made by another; he could identify facets of the plan that had fallen into place, and he supposed other facets would fall into place, that the plan was not fully revealed yet. He knew this was not one of the uncomplicated sort of plans that Babcock would make, or the privately oriented plan Moses would make, or the adventure-conscious plan Esau would make; this was an im- 
personal, intricate, complete plan, founded on a natural sense of balance and justice. It was more like a plan he would make. Lie still, he told himself, and save your strength. Lie still. If you struggle, you'll only be the silly insect in the web.

He saw the first sunlight filter into the cave. His teeth were chattering, and he suffered painful chills and streaks of fire in his body, but he lay still.

All night he had heard the hollow tone of the wolf howls, which had become closer and closer until they were nearby, even at the cave's entrance. Why had the wolves not come into the cave? he wondered. Wolves knew the mountain, every cranny of it. What did they know about the cave that had kept them out of it?

He concentrated on himself and asked if he should continue to lie on his belly or if he should try to turn onto his back or side. It was difficult through the pangs of pain to keep his mind on any one subject; an idea seemed to him to be slippery, like the hand he had grasped in the night. If he were to turn onto his back, he could see the entrance of the cave, and maybe, conceivably, there would be somebody pass that way. There was small likelihood of this, but it was a hope, anyway.

He took hold of his injured leg and moved it. A fierce pain went through him. He moved it again, turned it ever so slight$\mathrm{ly}$, watching the leg, trying to see where it was broken and how best to hold it. He turned it again, until he was lying on his back. His eyes were tightly closed now, and he let the pain course through him until at last the pain was only a throb. He realized there were tears on his face.

A man crying, he thought.

"You have my leg, don't you, woman?" he said to the mountain. "You have my leg in your jaw."

No, he thought, she has me, all of me in her open mouth, and she will eat me alive if she can.

Since Mud Cut she had waited so quietly, he thought, ignoring the work on bridges, tunnels, cuts, embankments, camps; then with one single move she crippled it all.

The light grew brighter. It was another clear day. He 
looked up at the ceiling of the cave and saw the light as it vibrated and was shadowed by the moving branches near the opening.

How strangely they move, he thought, not quite like shadows of branches at all.

He glanced toward the cave opening and saw the snakes, moving as if in rhythm to a tune. They were crawling on the rock entryway, and it was their shadows he had seen.

His gaze trailed along the ceiling and walls of the cave; here and there in the walls he saw other snakes, not moving now, merely lying asleep. They were the color of the rocks, and he could scarcely make them out. They were denned-in rattlers, lying in this cranny and that one, here and there, lying on the rocks all around, responding to the temperature changes around them.

He wanted to cry out, but he didn't dare utter a sound. If he was in the mouth of the mountain, he thought, then the tongue of the mouth was awakening now. The sun was rising and more and more light and warmth would come into this place; the snakes would awaken, the membrane of the walls would awaken, the threads of the web would awaken.

He lay there helpless and watched as the light increased, saw the membrane of the walls moving, first slowly as the light began filtering inside, then more actively.

He felt no pain in his leg now. His mind was clear. Nothing complicated the one idea he had at this time, the snakes and the necessity of survival. Even if he could move quickly, the snakes would strike him many times before he could reach the narrow lips of the cave opening.

Death would take him when the mountain decided, he thought grimly, when she was hungry for him. He couldn't even hope for mercy. There was no way to discuss anything with her or negotiate any compromise. What could he say to the walls of the mouth that would devour him?

Mildred, he thought. Please God, keep her away from even knowing of this. Anna, the thought; what if she were to find me? She would crawl through that narrow opening to me, and 
only then, looking back at the sunlight, would she see the snakes on the walls. Too late. Too late.

He saw her coming. "No," he told her. "Go away. Go away. Anna, go away."

Suddenly she was gone, and he realized she hadn't been there at all.

He saw a hand on the rock just outside the opening. "Mildred," he said, rising to his elbows, aware that the snakes were moving more vigorously, now that he was talking. "Go away, Mildred."

The hand on the stone was not a hand at all.

He lay back, gasping.

He saw Mildred in the stone ceiling of the cave, coming toward him, walking in a white dress down a dark road.

The mountain boys didn't work as a team. It was simply that now and then one or two of them would go out with a dog. They walked into the woods, and the woods seemed to absorb them. Soon after they had left the Tunnel Station, Cumberland would lose sight of them, then would notice a movement near a rock and realize a boy was there, standing, looking, listening, sensing. The boy would go on a ways, always appearing to be unconcerned, unhurried. He was asking more than he was saying; he was wondering more than he was deciding; he was waiting to be accepted into the natural way of things. When he was part of the way things were, the mountain would perhaps reveal to him the secrets it held.

Even though the mountain boys didn't go out together, by mid-afternoon five of them were crouching silently before the opening of the same cave. Their dogs were quiet, too. There was no sound, for the boys didn't talk to each other. They watched the entrance of the cave and listened to the man inside, who was talking. They didn't listen to what he said particularly. He was talking sometimes to his wife, at other times to other people. He was talking only in his delirium, they realized.

The boys didn't call for help. There was no need here for 
more people. Better for the guards and convicts, and others of unfeeling natures, to stay away now. Such men had their methods, which were to blast and dig. Those ways wouldn't do here. This wasn't a challenge of power, nor of mind, but of temperament. It required that one first know the feeling of what he was dealing with.

The boys could see the snakes. There was no way into the cave except to crawl by them. The opening of the cave was less than four feet high and four feet wide. The cave itself widened into a room, but not a large room, and even that was lined with snakes.

A sixth mountain boy arrived and, without a word, crouched nearby and waited.

The man inside the cave began to call. They could make out what he said. "Help," he said, over and over. Probably he didn't know they were there. It was as well he didn't know for he might do something suddenly, might try to force the trap, which would only make it close on him all the more.

One boy-his name was Dozen, for he had been the twelfth child in his family-crept closer to the opening of the cave. He began to sway, so that his shadow moved against the floor and walls of the cave. Later he began to hum to himself. He was humming a hymn, as if to keep himself company.

The man inside the cave grew quiet. Maybe he saw the shadow or heard the hymn; maybe it simply penetrated his confusion and he was trying to determine what it was.

Dozen, swaying, humming, moved close to the mouth of the cave. Another boy crept close, too, and quietly, ever so quietly, began to sway and to hum the same tune. The music was soft and very slow.

A third boy began to whistle the tune, then the other began humming or whistling. Sometimes a boy would stop for a while, then he would start again. Nobody gave directions; they did as they felt like doing, all of them watching the mouth of the cave.

Not a sound inside the cave.

Crouching, Dozen moved to the very mouth of the cave. 
He swayed slowly and hummed more loudly, and as if in reply the snakes began to move, those near the cave entrance first, then the snakes farther back, swaying gently as they clung to the walls and ceiling of the cave, until all the snakes were moving, the walls were swaying to the movement of the boy.

Dozen crawled into the mouth of the cave, humming, the boys behind him swaying and humming and whistling gently, watching the mouth of the cave. Somebody far off in the woods shouted, but the boys didn't answer and not even one dog moved, as Dozen moved farther into the cave, humming.

Dozen touched Weatherby's foot. He moved forward until he was lying beside him. He waited until Weatherby saw him. Weatherby started to speak, but Dozen shook his head slightly, ever so slightly. Weatherby was trembling all over and his teeth were chattering, and Dozen motioned toward the entrance to the cave. He took Weatherby's hand and arm and began to turn him in the cave. His body contracted in pain, so Dozen waited until he saw the blood on the floor, then moved first the injured leg, then moved Weatherby around so that his head was closer to the entrance of the cave.

Dozen was on all fours now and was close to the top of the cave; the snakes were moving back and forth, brushing against him. He dragged Weatherby toward the entrance of the cave. He could see the mountain boys outside crouching, swaying, humming, and from far off he heard the bothersome noise of a man shouting. That could be the disaster to all this. More quickly he pulled the body toward the entrance of the cave, where the snakes were swaying across the entryway.

He reached the entry way and crept through, leaving the body just inside; he crept free of the cave and fell forward on his face on the ground and lay there, breathing deeply, gasping. Another boy reached past the snakes, grasped Weatherby's hand, and began to pull his shoulders through the hole in the rock. When Weatherby's head was outside the cave, his delirious eyes stared blankly at them. There was no sudden movement even yet, no abrupt sound, except of the stranger shouting as he came toward them through the woods, 
too close, too close. Hush, they thought; what sort of fool was it that shouted in the woods?

Weatherby's waist was through, the snakes weaved over his body. Slowly the boys pulled his legs through; they pulled him out onto the rock and two other mountain boys crept close to the entryway of the cave and hummed the tune, swaying more and more slowly, growing quieter, until finally the snakes stopped weaving on the walls and were still. said.

Dozen rose from the ground. "His leg is broke, is it?" he

"Splint two rifles," a boy said.

"That man that's shouting, go tell him to shut his damn mouth," Dozen said.

A boy left to find the man.

Weatherby dazedly looked up at them.

"Is he going to be crazy?" a boy asked.

"Likely to be," Dozen said.

"You shouldn't a gone in there, Dozen."

Dozen grinned. It was so, he knew.

"He don't appear to see us," a boy said. "When he comes to, he'll be as mean as old man Bentz was when he spent the night with snakes. He never got over it."

"Maybe, maybe," Dozen said.

The man who had been shouting was the guard Blackie, and he came to where they were and began to give them instructions. He said to make a litter. They said nothing to him, but they finished the splinting of the leg, then one of the boys picked Weatherby up by his sound leg and one of his arms and draped him over his own shoulders. He moved past Blackie and walked up the sloshy path past where the dogs were.

"I said make a litter," Blackie said.

The boys went on up the path, ignoring him.

The sun set beyond the mountain. The slope where the cave was shadowed early. There was no movement inside now, except that a snake crawled to the warm place on the rock where the man had been and coiled there.

The wolves began to howl. Their lonely sound came into 
the cave; the echo filled the cave as they came closer to the place. One wolf moved to the mouth of the cave.

There was a growl, then a yapping fierce challenge from the doorway, and a snake struck. The wolf backed away, showing his teeth, snarling.

The wolf turned and went back up the path by which he had come and disappeared quickly and silently. He had seen that the man was gone.

\section{The Road}

1. Why did it take so long for the road crew to discover that Weatherby was missing?

2. In fiction you learn about characters through the author's description. You can also understand characters through what they do and what others say about them. Using any of the above methods, find out what you can about Weatherby.

3. Explain the mountain boys' decision not to get help with the dangerous situation.

4. Personification is the attribution of human characteristics to inanimate objects. Find an example of personification of the mountain in this story. 


\section{MYLES HORTON (1905 - )}

The following interview appeared in Sojourners, April, 1986. Many years ago Horton recognized that nothing will change in Appalachia "until we change-until we throw off dependence and act for ourselves."

With Appalachian roots that go as far back as the Watauga Settlement, Horton grew up aware of the contradiction of Appalachia's richness and its poverty. This awareness led him to see the need for empowering the powerless in Appalachia. Consequently, in 1932 in the mountains west of Chattanooga, Horton founded the Highlander Folk School on the principle that poor, working-class adults could learn to change their lives. In the years since then, his primary aim at Highlander was to teach people how to think and how to analyze. Such teaching, begun in the days before unions were commonplace, produced early union leaders. In the 1950s Horton turned the emphasis of his workshops to civil rights.

Because of Highlander's devotion to change, a governor of Georgia called it a "cancerous growth spreading throughout the entireSouth." Thestate of Tennesseeclosed it down, confiscated its property, and sold it at auction. The Ku Klux Klan beat up its staff and burned the buildings. Highlander is still controversial to some.

Nevertheless, Highlander, now located near Knoxville, Tennessee, has survived to celebrate its 50th anniversary and 
still follows Horton's philosophy: "We believe in people keeping a lot of their old customs and adding new ones."

\section{Building Democracy in the Mountains}

SOJOURNERS: In 1932 you started what was then called the Highlander Folk School. What was the dream for it?

MYLES HORTON: We were interested in building a democratic society and were going to use education as one of the means to changing society. We were openly out to change society and have what we called a second American revolution that would be an economic democracy as well as a political democracy. The purpose of Highlander has always been the same: to try to contribute toward a genuine democratic society through radical social, economic, political, and cultural change in this country.

One of the things that we felt was very important was to have a new type of labor movement, because at that time the American labor movement was at a very low ebb. We advocated that there should be a democratic, industrial-type union, and we hoped to get people in the mountains interested in unions and cooperatives and things of that kind as one of the means of building a democratic society. So that was a specific statement of purpose that more or less outlined the program of the school.

What do you mean when you talk about education? I'm not sure it's what people usually associate with that word.

Several years ago I was speaking at an alternative school conference. One of the people explained that Highlander was not a school in the sense of a college or any other kind of school because we didn't have classes, we didn't have credits, we didn't have this, that, and the other thing, and that we built on people's experiences instead of teaching them things they 
needed to know. And that's true. Highlander is not a school. But it is educational in the traditional meaning of the word "educate," which is to draw out instead of to pour in.

We think people become educated by analyzing their experience and learning from other people's experience, rather than saying there's a certain body of knowledge that we need to give them.

The philosophy of Highlander fits in well with the notion of a gospel that is good news to the poor and gives liberty to the captives.

You're absolutely right. We decided not to try to deal with all of society. We tried to carve out a segment of society to deal with that we thought was the most important-the poor, the working people, and the minorities.

If you say religion is to be judged by the way it treats the poor, then Highlander would qualify as religious. But we do that primarily out of an analysis of society. We want to bring about a fundamental change in society, and we think it has to come from the bottom up-it can't come from the top down. Anything that's given to people can be taken away. So we try to help people struggle to gain their own freedom.

One of the things that people always say about Highlander is that back in the '30s, '40s, '50s and even into the '60s, it was one of the few places in the South where black and white people could get together as equals and get to know each other in a new way.

Well, there was a Catholic school down in Mobile, Alabama, that quietly, off the record so to speak, had some black and white people. They tried to keep it kind of quiet, for good reasons. They would have been run out of town if they hadn't. Then there were other places where people would quietly get together. But Highlander was the place where people knew you could openly have social equality, and they knew it because Highlander brought down the wrath of the opposition. And since we were the only place that was attacked at that time for 
doing it, we were practically the only place that was known. That opened up the opportunity for us to work with black people and was well worth all the harassment and trouble.

Now all this was taking place before the civil rights movement. It wasn't framed as a civil rights issue because we put it all together on the basis of having a strong union, a democratic union, a union that could stand up and fight the bosses and get some benefits. And we said, "It doesn't matter whether you like it or not. You've got to take the women in. You've got to get old and young together. You've got to get everybody working together in a democratic set-up, or you won't have any strength." That was the angle we used. So the groundwork was laid, and although we weren't dealing with civil rights on a daily basis, a lot of black people and white people whom we worked with later became leaders of the civil rights movement.

How did what started as an economic struggle during the Depression evolve into a civil rights movement?

We finally came to the conclusion that we couldn't go any further in terms of economic, political, or cultural changes until we dealt head-on with this business of racism. We'd get so far, and then racism would be used against us. So in the early 1950s, around 1952 or '53-before the Supreme Court decision on Brown vs. Board of Education-we decided that we were going to have to consciously concentrate on dealing with the public aspects of segregation.

That's when we came to the policy of saying to black people: "OK, we'll work with you. You decide what to do, and we'll be supportive. We think that's the most important single thing we can do now, because we can't move on peace, we can't move on economic issues, we can't move on social life or anything else, until we crack that." Then we started trying to pull together people who would talk about racism, both white and black, and the basis for this was our old trade union people.

You see, to the labor people we added black people who, for economic reasons, were freed of influence from whites- 
preachers from black churches, beauticians, morticians, and other business people who only worked with other black people. A few people in education were involved, along with private people, black and white, who were more independent. But the basis for this was the labor people.

I understand that one of the first things to come from that work was the citizenship schools. How did that come about?

I guess that's what you'd call one of the Highlander success stories. Our policy has always been not to go out and do anything anywhere unless we have students who start something and then ask us to come and help. The citizenship school program is a typical example of that.

A fellow named Esau Jenkins had come to a workshop at Highlander, and he was trying to get people registered to vote in Johns Island, South Carolina, when he asked if we could help. After doing some real analyzing and thinking about the situation, we came up with a very simple idea that the black people there called the citizenship school. It was what most people would call a literacy school.

The law required blacks to read a part of the U.S. Constitution before they could register, and so it ruled out illiterates. If you had a certain amount of property or wealth, and you were white, you didn't have to be able to read to vote. But if you were black, you did. So our program was really a way to help people get to be citizens. That's why they called it citizenship school.

Out of that program grew a lot of leadership for the civil rights movement. Some people credit the citizenship school program for being one of the bases of the civil rights movement. It was simply black people teaching black people in a system of adult education based on what's called popular education now, especially in Latin America. It was based on the fact that if you know just a little bit more than the people you're teaching, you are closer to them and you can help them. You don't need to have expertise to do it, but you have to respect the people you' re dealing with. 
That program spread, and later on Martin Luther King, Jr. asked me if I would work out an educational program for SCLC (Southern Christian Leadership Conference), which didn't have an educational program. After spending a month or so thinking about it and visiting some of their programs, I came to the conclusion that the citizenship school program was ideal for them. They accepted the program, and that became the official program of SCLC. It became a big program, but it started out in the back of a little co-op which we'd helped set up.

Was it during the period of involvement with the civil rights movement that Highlander really faced enormous persecution?

If you're not facing some kind of resistance from the people in power, then you must be a traitor to your cause. So you can be sure that if you're accepted by people who are struggling, then you're going to be harassed by people who want to keep the status quo. So in a way it's a measure of your involvement.

What form did that harassment take for you?

Well, I've had ribs broken and my skull fractured. I've still got a crack in it. I had teeth knocked out, collarbone broken, arms slashed, but all of it short of death. Now, I had to go to jail like everybody else, but that was no problem-you got a little rest. So on a personal level you had to take punishment.

One thing a lot of white people don't understand is that we have a certain advantage in the fact that we are white. They'd beat me senseless. But they'd kill a black person. They didn't quite dare kill me. That would have been embarrassing. In fact there were instructions in writing by the FBI to the officers in Mississippi when I was there not to kill me. There weren't any such instructions not to kill black people.

As far as Highlander itself was concerned, they tried every way in the world to harass us. They tried to have vigilantes come and run us off and try to burn the place, but our neighbors protected us. Then they had a state investigation to try to 
put us out of business, and that didn't work. Senator James Eastland's Internal Security Subcommittee came, but that didn't work. Finally they raided the school and set up a case over a two-year period during which they bribed local people to testify; but even after all that, most of them got mixed up and said the wrong things. They finally found a technical way of getting us by charging us with selling liquor without a license for having a cooler of beer with a collection cup beside it.

The one thing we pleaded guilty to was the one thing they were concerned about-running an integrated place. We very proudly said we'd been doing that for years and were going to continue to do it. And it was that issue that got us in trouble.

And you were raising a family during the worst of those times?

Yeah, I was raising two kids. My wife died when my kids were 10 and 12. All their childhood lives, they lived in this period of harassment during which I had to send them to a neighbor's house when we'd be attacked. And they used to hear all this hate stuff on television and radio and from preachers and read about it in the paper. So they grew up knowing all about that, and they'd just kind of bear with it.

My daughter was going to a local school, and the teacher would say, "Comrade Charis, will you read?" And then the teachers would say, "Well, you better get back out there with those little nigger kids you live with." So the kids didn't have an easy time, but it was more than made up for by their growing up knowing wonderful people. They knew Rosa Parks just like family.

That's important because, as you said, when you take certain stands about how you're going to live your life, you can expect the things you experienced at Highlander. People may not fear that for themselves, but they fear that for their families.

I was asked at one of the state investigations of Highlander if I felt like I had some obligations to live a more normal life and 
assume my responsibility as a parent for my children. I was also asked what kind of heritage did I think I was leaving them. I said I thought I was leaving them the best heritage that I could. I thought it was important to leave them a heritage that they wouldn't be ashamed of. I thought that was much more important than playing Little League baseball with them or doing some of the things that the investigators thought were part of a parent's duty.

So I don't feel that you neglect your kids when you do something that they can be proud of. I'm happier now that my kids are not ashamed of Highlander, not ashamed of me, and not sorry about their own lives, than I would be if I'd left them conventional sorts of memories and money and things of that sort. And they're better off.

One thing that is pretty unique about Highlander over the whole span of the last 54 years is the role of culture, especially music, in the education and agitation work that's been done here.

Even before Highlander started, I was making notes on some ideas that I'd like to see incorporated into it. One of them was the use of culture, music, and drama as a way of saying things that you can't say otherwise. You can say things in music and in dance and drama and poetry that are not exactly the rational step-by-step sort of things. I always conceived of that being important.

"We Shall Overcome" was just one of the many songs that were brought to Highlander. It came from Charleston, South Carolina, where the American Tobacco workers were on strike. Like a lot of people, they made up songs based on their hymns. And they brought to Highlander a pretty rough-hewn song they' $\mathrm{d}$ made up. With my wife Zilphia's encouragement, that song grew. It had something to it that people just kept singing it. When Martin Luther King, Jr. heard it, he said, "This has got to be the hymn of the civil rights movement." Zilphia collected such songs and put out music books that spread all over the South and were used during the civil rights movement and the 
labor period.

There's a story that one of the verses for "We Shall Overcome" came into being much later at Highlander.

There was a black Baptist church youth choir from Montgomery, Alabama, and Septima Clark, a black woman on our staff, had made arrangements for them to come up. While they were eating and looking at a film, there was a raid.

People came in with guns and demanded that they put on the lights. But nobody would put on the lights. The people had flashlights and showed their guns and kept demanding that they turn the movie off and put on the lights. No one knew whether they were vigilantes or the law. It turned out that they were deputies and people who'd been deputized for this raid. Soon the kids started singing "We Shall Overcome," and they added that verse "We are not afraid." And Septima said it just infuriated those people, the whites, to have these black kids sing, "We are not afraid."

I have only one musical credit in the world. I can't play or sing, but as we were making up verses for songs, like we always do, I had a feeling that there was a lot of uncritical thinking going on about some of the hard issues of civil rights. I was trying to think up a verse that would say that we have to keep searching for the truth and not just assume that we have it.

So I finally said, "I haven't been able to figure out any line that fits this idea, but maybe somebody else can help. It's the search for truth that will make us free, not the struggle." So they immediately started singing, "The truth will make us free," and I said, "No, no, that's not what I mean," but it was too late. From that night on, "the truth will make us free" has been a part of that song. And that's the only contribution from my musical career.

You said there was a shift at Highlander from working primarily on labor issues to working more on racial and civil rights issues. But then here was another shift when the Highlander Center again became very much identified with Appalachia. 
Well, first of all, we started out working in Appalachia, and worked here for the first four or five years, and that established the idea that we were Appalachia-based. And then in the '60s, after working on racism and civil rights issues, we switched and started back to working on Appalachia, as part of the Poor People's Campaign.

One of the reasons we concentrated on Appalachia was we thought there was a possibility of building that alliance among all the groups of poor people. If we were going to be part of that coalition, we would do it as part of Appalachia.

About four years ago, we decided we'd gone as far as we should go in working on Appalachia, and we announced that we would open up the workshops to folks in the Deep South again.

In the South we're working on some basic civil rights issues through cultural programs, voter registration, and our work with the Federation of Southern Co-ops in Alabama. Here in Appalachia, the women's movement is important right now. Women are beginning to make demands and make some headway, and women miners are getting organized. A lot of that work is connected with people at Highlander.

You said that at Highlander fundamental social change is the objective and that at different times Highlander may work on toxic wastes or union rights or civil rights. How does your work on the specific issues, some of which you may win and others you may lose, relate to the larger objective?

I think there are two things involved. One is that what results in a revolution is a culmination of a lot of things that have their fruition at a certain time. But the revolution is being built all along.

What you do is build little cells of decency, little cells of democracy, little experiences of people making decisions for themselves, little philosophical discussions about civil rights and human rights. All of those get built into what's going to 
happen later on.

So you're really building for the revolution when you do something to develop local leadership. You get some satisfaction out of seeing steps as you go along, even though you don't get all the way.

Then, if you're around long enough, you see things like the industrial union movement, the civil rights movement, the antiwar movement, and other movements that seem to get something done. So you know people can do things. A lot of people today have never seen anything succeed.

I've seen things succeed. I know people can do things. I've seen the complete labor movement restructured; I've seen the civil rights movement. I know people can make changes. They' re not making them now, but they're building things. The time is not being wasted. But it's not being fully occupied either.

The purpose of Highlander is not to solve problems but to use problems and crises as the basis for educating people about a democratic society. To make them want more, and make them understand they can do more.

I think you need to challenge people. I think you stretch them as far as you can. I think you have expectations that you share with them and you give them help.

I feel very strongly that people have the capacity to go further. You've got to deal with people's self-interest, some say. Well, I agree with that, but their interests are much broader than most people think. Their personal interest includes a willingness to struggle, a love for their country, a love for humanity. Those are personal interests too. It isn't just feeding your belly and getting some clothes on and getting a little security. Those are personal interests, they're valid and they're important. But these other things are personal interests too. And you can challenge people, you can build with people on those things. And if you don't, it seems to me you're minimizing the humanity of people. 
MYLES HORTON 309

Building Democracy in the Mountains

1. What are the fundamental goals of Highlander Folk School?

2. How does Horton believe that people learn?

3. What were the citizenship schools, and how did they demonstrate Horton's philosophy? 


\section{COMPOSITION TOPICS}

1. In your library read about the Tennessee Valley Authority or the atomic bomb and decide what aspects of it will make a good report. After you have narrowed your topic, write a paper using at least three resources on your topic.

2. The pieces in the chapter you have read show America coming to the mountains. Is this progress? Write an essay defending your opinion.

\section{ACTIVITIES}

It is likely that your parents and grandparents have experienced empowering changes in their lives. Interview these family members to find out about such changes, write about these changes in narrative form, and include them in your book.

Ask about the time the parent or grandparent first got electricity in his house. Be sure to ask how he felt about it.

Ask about changing from farming to working in a factory or a store. Be sure to include feelings about the change.

Find out about the first woman in your family who worked outside the home. Include family reactions and the woman's reaction to her work.

Ask about the first automobile in the family. If possible, include an illustration of it.

Find out about the first labor-saving devices: washing machine, sewing machine, vacuum cleaner, power lawn mower, tractor, refrigerator, etc. 
Contrast your school with your grandparents' and parents' schools. 
This page intentionally left blank 


\section{CHAPTER 5 \\ Moving Mountains: \\ The Struggle of the Coal Industry}

Many people, both inside and outside the Appalachian region, have a negative view of the coal industry. This is easy to understand. In the early days of the industry, no attempts to protect miners existed. No one had ever heard of environmental protection. Consequently, the only news from the coal industry was the bad news of explosions and cave-ins that killed many men. Photographs of abandoned stripmines that scarred the land and polluted the streams accompanied the news.

People soon noticed also that despite this abundant natural resource and its profitability, the region and its people remained dismally poor. The standard of living in the coal-producing sections of Appalachia was among the lowest in the nation. The highways, schools, and health care facilities were substandard. All the money from coal was going somewhere else. But finally as Myles Horton, a writer in Part II, had hoped, the power of the people-and truth and fairness-brought change. 
Edwin Hoffman's article in this chapter details some of the long struggle that led to changes in the laws. Labor unions, political activists, some lawmakers and community leaders in coal mining areas worked together toward a common goal. Stringent health and safety regulations now exist for mine operation, and the government spends a large sum of money to help enforce these laws. After 1977 the federal government has required that coal operators restore mined land to its original contour. This means that the used land has to be reclaimed and made productive.

The coal industry has become more responsible in recent years, but it is still struggling. Its efforts to improve working conditions and reduce accidents and illness among miners have achieved respectable success. Nevertheless coal mining is still one of the most dangerous occupations in the United States. Competition from foreign coal has hurt the industry and caused loss of sales and jobs. Some small coal companies have responded to this economic difficulty by avoiding their obligations to workers, the land, and the community.

All in all, the coal industry has made tremendous strides in the past twenty years. Many of the larger companies are now spending much money to educate the public about the industry's efforts to improve itself. Coal Appreciation Week, children's poster contests on safety, a public schools program featuring coal company engineers and tours of active and reclaimed mines are new to the coal fields. They are designed to show the industry's contribution to life in the region. 


\section{DON WEST (1907- )}

A mountaineer and native of Georgia, Don West has been a minister, teacher, labor organizer, and poet. His first book of poems, Clods of Southern Earth, has sold more copies than any other book of poetry in America except for Walt Whitman's Leaves of Grass.

In 1964, West founded the Appalachian Southern Folklore Center in Pipestem, West Virginia, which helps local people understand their cultural heritage.

His poem "Harlan Portraits" says beauty is a stranger in the coal camps.

\section{Harlan Portraits}

I've seen the beauty in Harlan, In the trailing arbutus, The dogfennel and pennyroyal In the fence corners, The forest dressed In a foliage of Rattleweed and ditney. I've seen beauty when Gray winter strokes his beard 
316 Moving Mountains: Struggle of the Coal Industry

With boy-white fingers,

And trees are skeletons

Of summer's glory...

But beauty

Never visits the coal diggers.

They live in the coal camps-

Dirty shanties,

Stinking privies,

Grunting pigs,

And slop buckets...

Gaunt-eyed women

With dull hopeless faces

Cook soggy wheat biscuits.

Tall gaunt men

Eat soggy bread

And fat meat,

Gulp down black coffee,

Work all day-

Digging, digging,

Everlastingly digging.

Grime and dirt

And digging

In their dreams they dig

And smell unpleasant

Odors.

For beauty

Is a stranger

To the coal camps... 


\section{Harlan Portraits}

1. A metaphor is a direct comparison between two unlike things. Find the metaphors in the first stanza of the poem.

2. Why is beauty a stranger to the coal camps? Is it possible for any place to be completely devoid of beauty as the poet suggests? 
318 Moving Mountains: Struggle of the Coal Industry

\section{Nine Pound Hammer}

This is a Kentucky coal-mining song long associated with Merle Travis. The Monroe Brothers version is used as an "answer-back," with the tenor echoing each line and singing along on the last.

It's a long way to Harlan and a long way to Hazard Just to get a little booze, just to get a little booze.

Oh, the nine pound hammer killed John Henry Ain't gonna kill me, ain't gonna kill me.

There ain't one hammer down in this tunnel That can ring like mine, that can ring like mine. Rings like silver, shines like gold Rings like silver, shines like gold.

Buddy when I'm gone, won't you make my tombstone Out of number nine coal, out of number nine coal.

I'm going on the mountain, just to see my baby And I ain't coming back, no I ain't coming back. 
319 Moving Mountains: Struggle of the Coal Industry

\section{Nine Pound Hammer}

1. Find evidence in the song of the speaker's attitude toward his work. What does the reference to size suggest?

2. This song contains an allusion to a popular ballad you have previously read. Locate the allusion and explain it. 


\section{HARRY M. CAUDILL (1922- ）}

Except for time spent in the military service and at the University of Kentucky where he earned his law degree, Harry M. Caudill has lived his entire life in Whitesburg, Kentucky.

Although he has published several books and articles, his first book, Night Comes to the Cumberlands: A Biography of a Depressed Area, has received the most attention. Published in 1963 , this description of his native region helped establish legislation which has poured millions of dollars into the Appalachian "poverty pockets" Caudill described.

This short story "The Mountain, the Miner and the Lord" from a book by the same name introduces us to Sam Hawkins, a black miner working to give his daughter the education he never had.

\section{The Mountain, the Miner and the Lord}

Sam Hawkins was enormous and coal black, with immense chest and shoulders and broad, work-thickened hands. When he told me this story he was about seventy-five, and time and arthritis had slowed him to an uncertain shuffle. But his eyes were still wonderfully alert, and in their dark depths there glowed immeasurable woe and much wisdom.

It was late November in the bleak depression year of 1932 
in the coal town of Fleming, Kentucky. The leaves had long since fallen from the few scrub beeches and oaks on the dark hills, and now gray, gloomy clouds hung near their rocky crests. Cold rain beat relentlessly against the tarpaper roofs and weatherboarded walls of scores of identical houses, and a pall of smoke, grime, and grit from the chimneys blanketed the narrow streets and sidewalks. Elsewhere a few well-to-do people had begun to think of Christmas, but in Fleming - and in countless other Appalachian mining communities-people only thought of survival.

The industrial crisis that had closed mills and factories had brought most mines to a complete shutdown and the others to a two- or three-day work week. Tens of thousands of miners were without jobs. Currency had disappeared as if recalled to the mints, and company scrip-redeemable only at company commissaries-was the medium of exchange. All the banks in the county (and most of those in adjoining counties as well) had folded, taking with them the savings of miners, merchants, and coal operators. The fear that lay in the valleys was more suffocating than the smoke-laden fog.

Sam Hawkins was forty-eight and had one child, Margaret. The girl was nineteen, big-boned and strapping like her father. Sam's wife had died in July after an appendectomy. The doctors in the shabby, hopelessly overcrowded little company hospital had done all they could for her, but in those days before antibiotics there was little chance to save her. Sam was with her at the end and, numb with grief and loss, he had ridden with her body in a company hearse driven by a company undertaker to a company graveyard.

Sadie's last words to Sam had been desperate: "Sam, honey, Margaret won't ever git to go to college! She'll be pore and helpless as we is!"

But Sam had not despaired. In the face of incredible odds he had sent his "little girl" off to Kentucky State College for Negroes at Frankfort when the fall term began in September. When she kissed him good-bye and climbed aboard a train, she carried all her possessions in a cardboard box. Wrapped in a 
handkerchief in her cheap little purse were fifteen one-dollar bills which Sam had gotten from an accommodating white politician in the county seat. For them Sam had exchanged fifteen dollars in scrip and three days of farm labor.

When Sam and Sadie had come up from Selma, Alabama, to the booming Kentucky coalfield they expected to find a little happiness for themselves. In the coal towns blacks were "damn niggers," and occasional lynchings kept black coal diggers cowed and quiescent. But life was far better, even so, than any they had known in Alabama. As long as the boom lasted they ate well and had enough clothes, and the company house was warm, dry, and neatly painted. Their daughter was a delight to both of them and they had vowed to educate her. She would go to college and would some day teach school. She would know how to do things they had never dreamed of for themselves - she would read and write. They nurtured a dream to "make somebody" out of their daughter, to see her and their grandchildren slip beyond the cruel oppression of poverty, insecurity, and endless toil.

Some things were encouraging in this respect. When the coal corporations constructed new towns in Letcher County they had built houses, stores, streets, hospitals, water systems, and schoolhouses-for white children. Several years passed before classrooms were opened for black children, and then only grade schools were provided, but it was a beginning.

In that time and place a high school education was a luxury many communities could not afford to provide. In the struggle to build secondary schools the black children and their parents were forgotten and a stern state law prevented integrated classrooms. As Margaret made her way up through Fleming Colored Graded School her parents watched her progress with a pleasure that was tempered by a growing anxiety. Unless a high school could be built soon, their daughter's education would terminate abruptly in her fourteenth year. Sam commenced working on this problem and, as he phrased it, "The Lord blessed me, he shorely did!"

One summer day Sam rode a train fifteen miles down the 
river to Whitesburg, the shabby little county seat, and, hat in hand, he entered the office of the county attorney. He believed the official's condescension covered a kindly heart and told him his worries. He asked the lawyer to draft a petition to the fiscal court and board of education. The instrument, as pecked out by the attorney on an ancient Underwood, "humbly and respectfully" requested the building of a high school for "colored students" who had "completed the course of studies required for an eighth grade diploma." Sam left the crumbling brick courthouse apprehensive at the thought of the immense task he had undertaken.

In the next few weeks he collected the signatures of Negroes-or more generally their marks, for few could write. Then, when virtually all blacks in Fleming and other nearby towns had marked the paper, he submitted it to white miners, housewives, merchants, and company officials. Most signed, with sly winks and nods to their fellows, though not a few refused because they did not believe in "educating niggers." Some said bluntly that taxes for white schools were burdensome enough without the extra expense of "nigger schools." But the list of scrawls and X's grew steadily longer.

One day Sam and a black preacher enlisted the aid of another white official, a one-armed former coal miner, and laid their tattered document before the eight tobacco-chewing justices of the peace who made up the fiscal court. Two members insulted them for their pains, but others were more sympathetic. A year and a half later, the county board of education, the fiscal court, and the school officials for the independent district in the town of Jenkins reached an agreement: a high school would be built in Jenkins and administered as a part of the town's system, but the county would contribute annually to its support. Black children from both school districts would attend it.

When the news came, Sam and Sadie felt a glow of pleasure greater than either would ever know again. Sam believed the Lord had done it and said so to all who mentioned his achievement. But before the first stone was laid in the building's foun- 
dation Margaret had brought home her grade school diploma. She would have to repeat her last year's work while the carpenters built her high school and administrators struggled to find, somewhere, a black faculty. It was a foregone conclusion that whites would not teach in such an institution.

Fifteen hundred blacks celebrated the opening of their new citadel of learning with a barbecue and home-brewed beer. The preachers prayed long and fervent prayers of thanksgiving. Sam was lauded as the man "who had a vision," and the white school men patted him on his back and congratulated him. That was on a spring day in 1928 when the world was rosy. Margaret got her high school diploma four years later after the sky had fallen, when most men's hopes were as cold as the slate that towered in vast heaps above the coal camps. She read the ornately inscribed certificate to her beaming mother exactly one month before the white undertaker screwed down the pine coffinlid above Sadie's face.

Now as he trudged along the rain-drenched street in the last light of the dying day Sam sagged beneath a new burden. As he turned and mounted the three wooden steps to his door he carried the only food he possessed: a wedge of cheese and a five-cent box of soda crackers. The fire in the grate had dimmed to a mere handful of glowing coals that responded slowly when he knocked out the ashes and added lumps of fresh fuel.

He drew a letter from his pocket and stared at the lines that ran boldly across the white sheet. Sam could not tell one letter from another, but Amos Bryant, the postmaster, had read the brief note to him, and the disconsolate man still remembered every word. There was no escaping them nor what they portended for his child and for his own worth as a man:

\section{Dear Papa,}

I miss you and Mama more than I can ever say. Both of you were always so good to me.

My school work is very good and my grades are fine. I really like school a lot. 
It looks like I will have to quit school, though, in a few days. My money is all gone and the little work I get is just enough to buy food. Unless you can manage to send me ten dollars I will have to come back home. It will break my heart but I know it will hurt you far more. Maybe that would be best after all, though, because then I could be of some comfort to you in these sad times.

Your loving daughter,
Margaret

Sam's only money lay on the mantlepiece-fifteen cents in the brass scrip of Elk Horn Coal. It was Thursday night and no work for his section of the mine was posted on the board by the payroll window before Monday. A miner was paid on a piece-work basis - thirty-one cents per ton for drilling, blasting, and loading the coal into cars. The company hired a man to undercut the coal at the face, and the miner did the rest. The miner provided his own tools and smithing and the carbide for his lamp. He had to pay the company for the explosives he used. If he was lucky he would net two dollars in eight to ten hours-two dollars in scrip. And if he didn't like the terms he could bring out his tools and starve. Since there was no alternative, the men hung on to the awful jobs, and miners and company together had settled down into abject ruin. Ten dollars was a fortune wholly beyond Sam's reach. He could not borrow, because there was no one with money to lend, and if someone possessed a bit of cash, would he be so improvident as to lend it to a penniless black coal miner? Sam groaned in despair.

The droning rain sluiced against the windows and wooden walls. The wind whirled soot down the chimney and howled about the eaves. Suddenly a new sound emerged from the turbulent night as heavy feet walked across the porch. Knuckles rapped against the door and when Sam, glad to have any visitor, yelled, "Come in," the door swung back to admit a blueuniformed company policeman.

The spectacle of the officer, his raincoat dripping puddles on the pine floor, sent a new wave of dread along Sam's spine. 
He had violated no statutes, but a few days earlier he had talked to a representative of the United Mine Workers of America about the possibility of organizing a local. Company spies were everywhere and such "ingratitude" was cause enough to evict an offending miner from company property. And where could a man go on such a night as this?

The policeman looked about the room with its simple furniture, the framed snapshot of Sadie, and the crochet work with which she had tried to bring some beauty to the graceless place. He licked his lips and stared at Sam with pale, uncertain eyes.

"Sam," he said, "the superintendent asked me to stop and tell you that he has a chance for you to make some real money. Yes, some real good money! One of the sections has mined out too much coal and a big pillar is taking weight. The men in that section are afraid of a general roof fall, so they won't go into the place. The super says you are the best coal loader in the camp, and you can work all night if you want to. The weight is pushing the coal out from the pillar, and you won't have to do a thing but shovel. A man can load an awful lot of coal between now and daylight." He paused, then added, "The engineers say they are pretty sure the top will hold for another twenty-four hours or longer and, anyway, an experienced miner like you, Sam, can generally tell when the fall is coming in time to get out to a safe place."

To the policeman's amazement the black giant rolled his eyes heavenward and with utter sincerity murmured, "Thank ye, Lord!"

Sam put on his work clothes-long cotton underwear, faded bib overalls, blue denim shirt and jacket, knee-high rubber boots, and a soft miner's cap with a carbide lamp attached to the front. He pumped a half gallon of fresh water into the bottom section of his aluminum dinner bucket and dropped the bit of cheese and handful of crackers onto the food tray.

A few moments later he reached the office of the mine superintendent. The superintendent leaned back in a creaking oak swivel chair and explained how a foreman had permitted a little too much coal to be removed in Section 4-B Right. "A 
squeeze is coming, Sam, and the whole territory is going to be lost in a day or two. There is a lot of fine Elkhorn No. 3 there, and if we don't get it tonight we never will, because the whole mountain is going to set down on it." He cleared his throat. "The track is laid up to the face of the coal. It will squeeze out as fast as you can load it and push it away. We can set all the cars for you that you can possibly load. There is no night shift, but we will leave the fan running, and there is no reason why you can't work all night in there by yourself."

He toyed with a paper clip and tapped Section 4-B Right on the mine map that lay before him. "We will pay you thirtyone cents a ton and that is straight pay. No deductions for anything. You'll not need to do any blasting and the only tool you'll need is a shovel. There is a man-car waiting at the drift mouth to take you to the face."

Sam left the warm room and strode through the icy drizzle a hundred and fifty yards to the drift mouth - a huge, arched hole framed with concrete where steel rails reflected the glaring rays of a battery of electric bulbs as they curved into the black shaft. As Sam approached the opening, water rushed in torrents down the denuded slopes, and the tortured mountain, hard-pressed from within and without, loomed immense and terrifying. Just inside the tunnel Sam climbed into an empty car and slouched low against the wooden side. Propelled by an electric locomotive the car hurtled along the heading. Every six feet black locust timbers held up a sawed eight-by-eight white oak "collar" to secure the roof. Two miles from the portal the little train slowed and turned sharply to the right, then sped along for a couple of minutes longer. After another turn to the right it whined to a halt and Sam straightened up to look along the shaft of light from the locomotive that poked like a yellow finger into the darkness.

Where the track turned off into the working place, a long line of empty cars waited on their rusty steel wheels, each loading about 4,000 pounds when filled and "rounded over." From them the rails stretched to the face of the "pillar," a huge rectangle of glittering coal forty feet wide and at least eight feet 
thick. The seam rose from the smooth slate floor straight up and seven feet to the sandstone roof. About its base lay a twofoot ruffle of loose coal, and as Sam filled his lamp with a fresh charge of carbide and turned up the flame to its utmost the roof creaked and groaned and new lumps pushed outward onto the floor. Here and there small slabs of slate had splintered upward out of the floor under pressure from the descending shaft of coal. He lifted out his dinner bucket and set it and his pick against the "rib" or wall a dozen yards back. He put his shovel in an "empty" and pushed the car to a spot within easy shoveling distance. Then the motorman said, "So long, Sam, and good luck," and sent the locomotive careening down the track.

Sam set three white props before he began shoveling, driving hickory cap wedges across the top of each of the eight-inch timbers until it was tightly seated. Ten times as much oak would not protect him from the sandstone ledge that sagged above his head, but the props would serve as barometers by which he could gauge the mounting pressure. As the coal pillar yielded, the oak would splinter and shred, crying in protest until it broke.

He picked up the shovel and with a fervent "Be with me, Lord" pushed it along the slate until the broad scoop was filled, then lifted it and dropped sixteen pounds of Elk Horn No. 3 coal onto the wooden bottom of the car. The clatter sent echoes reverberating along the dark shafts and brought a faint whisper of the original sound back to him a few seconds later. Rhythmically, steadily, the shovel rose and fell, the black heap rising moment by moment until it lay glittering and uniform along the entire length of the seven-foot car. Despite the cool clamminess of the air the ventilation fan pushed in to him, Sam's forehead beaded with sweat and when he dropped the shovel to push the loaded car onto the side track he laid aside his jacket. He pulled a brass disk from his pocket and hung it on the "check horn" at the front of the car. The "check" was marked with his number, 67, and would tell the weighman at the tipple that Sam Hawkins had loaded the coal. The workmen had no "check-weighman" at the scale house and 
Sam could only pray for honest weights. He put his shoulder against another empty and brought it to the face. When he picked up the shovel, the coal he had carried away had already been replaced by new lumps from the breaking face.

For hours the shovel ascended and descended, interrupted only by forays for new cars. After a while Sam lost all track of the number he had loaded. Sometimes he put fresh carbide in his lamp or paused for a drink of water from his bucket. He commenced work at a quarter past eight, and four and a half hours later his pocket watch told him it was time to eat the cheese and crackers. The morsels were gone in a half-dozen bites, and after resting his arms and back for a few minutes, he returned to the coal. This was no night for ease. The words of his girl's letter as brought to him by the droning voice of the postmaster sounded endlessly in his ears, restoring strength to arms that began to ache with fatigue. Once as he pushed an empty into position he wiped the sweat from his face with a gritty hand and murmured, "We goin' to do it, Sadie! We goin' to do it after all!"

A little after five Sam heard the rattle of the man-trip in the main tunnel, followed by the lights and voices of approaching miners. The day's work in 4-C Right was about to begin, and Sam, after laying the last lump on another car, straightened his back and leaned against his shovel. His legs, arms, and shoulders throbbed with great weariness, and his belly rumbled with hunger. His water bucket was empty and his sweat-soaked clothing clung to his gritty flesh. As he stared at the bobbing lamps he trembled and his head sagged against his chest, but the presence of other creatures after the loneliness of the night was wonderfully welcome. Words of greeting gathered in his throat but died unspoken. Suddenly the lights stopped as the men gazed thunderstruck with astonishment at him and his long line of loaded cars. A derisive laugh came from a lanky white man in front as he squatted on his haunches sixty feet away at the entrance to the short tunnel that led to Sam's doomed pillar.

"You crazy nigger," he called, "don't you know you're goin' 
to git mashed flat as a bean bug in there? The reg'lar shift quit that whole place yisterd'y and the comp'ny pulled out all its equipment!" Laughter rich with scorn tittered along the line of lights. Then as the men shuffled away over the uneven floor one of them muttered, "Man alive, that nigger shore does love to load coal!"

When they were gone Sam looked for the hundredth time at the props. Long ago the bark had loosened and long splinters stood out from the wood. He laid a palm against one of them and felt it vibrate like a tightened banjo string. Suddenly with a low hum a long filament the thickness of a match detached itself from the surface and hung by splinters from roof to floor. A bushel of coal rolled out to his shoe and a slate shard reared up like a tiny soldier out of the tortured floor. "It's time to quit," Sam muttered as he carried his dinner pail, jacket, and shovel into the safety of the tunnel. He leaned his shoulders against the "coal rib" for a brief rest before walking to the main tunnel for a ride to the outside.

But Sam's work-stiffened joints were not soon to enjoy the rest they had earned. As he whispered a good southern-style prayer of gratitude that the perilous night was safely past, a new light approached and the voice of Henry Johnson, a mine foreman, inquired solicitously, "Is that you, Sam? I sure am glad to see you safe and sound." He whistled with incredulity, "God damn! Did you load all these cars by yourself?"

Sam emitted a hoarse croak. "Well, me and the Lord together," he replied. "He held up the top."

The foreman counted the cars, seventeen of them, and then came back to stand before the miner. After a moment of reflection he walked down to the end of the track where Sam had toiled the night away. He held his lamp in his hand to inspect the props and pecked with a pick handle against the roof. It sounded solid, but grains of sand from the "working" top dusted downward against his upturned face. He whistled again, this time reflectively.

"Sam," he opined, "you did all right for yourself last night. You made some money and I know you need it. You're a good 
worker and you don't scare easy. This top is coming, no doubt about it, but not for a while, in my opinion." He put a chew of tobacco between his teeth, chewed, and spat out ambeer. Then in confidential tones, "Sam, what about another shift? If you feel up to it, I can send your dinner bucket out to the commissary and get it filled and have some more empties shoved in here and you can shovel all day. The superintendent sure will appreciate it if you decide to do it, but after all, you know the danger and you must use your own best judgment about it."

Sam drew in a long breath and let it out slowly. He thought of his weariness, of the shredding timbers, and of the popping sandstone. Then he thought of Sadie and Margaret, and rose to his feet. "Git me some grub and some empty cars," he said, as he picked up his shovel.

The day passed with infinite slowness. The clerk at the commissary who packed his dinner bucket was generous, but Sam did not linger long over his food. Yearning for some hot coffee, he washed his meal down with a long draught of fresh water. He prudently saved back half the food for "dinner time" about eleven. If all went well-and the top held-he should see daylight again by four o'clock that afternoon.

The food brought a flow of new strength, and for a couple of hours the shovel worked at its old tempo. But gradually the muscular arms and legs turned clumsy and heavy. The pain of weariness advanced in him until it gripped like a gray blanket from crown to toe. As the hours dragged by, a longing for sleep crept into every nerve and sinew, and the cars filled at an ever slower rate. He struggled to stay alert to the danger above his head-the danger that relentlessly reduced the props to columns of splinters and sent cupfuls of sand sluicing across the undiminished heap of coal at his feet.

When he heard the miners returning from 4-CRight, he laid his shovel on top of the last car and strained with all his remaining strength to sent it along the tracks. As it gathered momentum a red haze swam before his eyes and he staggered to keep up as the car rolled down the tunnel. Forty yards away he put on his jacket and drank the last of his water. He sat down and 
pushed his back against a coal car. "I'll rest jist a minute or two before headin' for the outside," he thought as he closed his eyes.

Sam dozed but his sleep was ended by a roar of cataclysmic proportions, an ocean of rending, crashing sound that hurled him down the tunnel like a puppet. The thick layer of sandstone had broken in the mined-out area behind the pillar and, crushing the pillar like a squeezed plum, sent a giant wave of coal rolling before it. From floor to roof the shaft filled with the tumbling lumps. Behind an impenetrable cloud gritty dust the avalanche finally halted twenty feet inside the tunnel, while the fall echoed and reechoed like dying thunder to the farthest corners of the mine.

When he left the man-trip and walked around the path to the bathhouse he blinked at the sun which was clipping the top of a western ridge. After twenty hours in the recesses of 4-B Right, the pale glinting rays brought tears to his reddened eyes.

When soap and water had washed away the dirt and sweat and eased some of the misery from his flesh, he put on clean garments and went to the commissary. The babble of voices in the showers and later at the food counters came to him as if from a great distance and he scarcely heard the friendly raillery of the miners. Sam was too tired to think of anything but sleep tonight and the mailing of a money order to his girl tomorrow.

He carried home a small bag of groceries and sat by the fire for a long time with a cup of hot coffee in his hand. The heat soothed him and as he relaxed he felt better than he had for months. He fried potatoes and bacon for his supper and "at the edge of dark" went to bed. As he pulled up the patchwork quilt Sadie had made especially to cover his huge frame he murmured again, as he had the night before, "Thank ye, Lord!"

When the payroll window opened the next morning Sam was there to claim his wages. The paymaster called the scale house to check the weights of the cars and as he talked he made penciled notes on a pad. When he left the phone, he went into the commissary to determine how much Sam owed the company store. He came back and smiled at Sam through the steel 
latticework. "Sam, you're in good shape. A few more breaks like night before last and you could afford to quit." He extended the note pad so the miner could see the totally unintelligible markings and, with the point of his pencil moving down the column, continued, "You loaded twenty-eight cars, averaging a little over two tons each, for a total of fifty-eight and a quarter tons. That comes to $\$ 18.06$. But you owe the store a little and that will have to be deducted." He named a few trifling purchases, including $\$ .23$ for Sam's lunch on the day before. "Your store debt is $\$ 3.98$, and that leaves you a balance due of \$14.08."

Sam let out his breath with deep satisfaction. That was more money than he had possessed in many months and Margaret was saved, for the moment at least. But suddenly his eyes widened with chagrin as the paymaster's hand deposited his earnings on the worn board-a fistful of brass scrip.

His strength drained away and a groan escaped him. "Ah no, no sir, not scrip! Not this time! The policeman say 'real money,' and this time scrip won't do. It jist won't do!" And he pushed the brass tokens back through the window. "If I don't git real U.S. money my little girl will jist have to quit school and I can't stand that, no sir!" and Sam, who had not quailed before the sinking mountain, now sobbed aloud.

The paymaster frowned. "You know we've got no money to pay out wages," he snapped. "Scrip is the best the company can do." Then he softened and added, "I'm sorry, Sam. I really am."

Sam stood in the pale autumn sunlight stunned and helpless, his tongue following his broad lips. But before utter ruin enveloped him, he was rescued-at least after a fashion. Another white man, "Mr. Tom" Haymond, the general manager, strode out of his office and approached the window. He asked the paymaster what the trouble was and listened to his explanation and to Sam's renewed plea for cash. He reflected for a long moment, his eyes going from the scrip to Sam's face and back again to the brass tokens. At last he nodded toward the door and said, "Let him in." Sam followed 
the "big boss" into his office and took the chair Haymond indicated. They stared at one another in silence for a moment.

"Sam," the executive began, "the company is grateful to you for what you did, but the company is practically broke, and that is the truth." He looked at the ceiling. "We have no money for anything except the most urgent mortgage debts. But I know you love that girl and I honor you for it." Another pause ensued. "I'll tell you what we'll do, if it's agreeable to you. If you can see your way clear to discount your wages from $\$ 14.08$ in scrip to $\$ 11.00$ in cash I'll pay it out of the little that's left in our emergency fund."

Sam sprang up and grasped the big boss's hand in wholehearted confirmation of the deal. Haymond turned the dials on the door of a safe and drew out of a slender envelope two greenbacks-a ten and a one. A few moments later Amos Bryant sold Sam a money order in the sum of ten dollars payable to Miss Margaret Hawkins. The postmaster sold him a stamped envelope for five cents and addressed it as Sam directed. When the envelope with its precious contents fell into the mail slot Sam walked out with sixty-five cents in his pocket.

The day warmed and was sunny and pleasant. Sam felt good again, and hopeful. And for a time things improved generally and he was almost happy.

A little more work became available and, with the passing months and the coming of the New Deal, wages rose somewhat. The miners organized a local union and working conditions improved. Sam was able to send Margaret money from time to time and the girl found a job that provided a little cash in addition to her food. Haymond and the superintendent favored Sam with extra work now and then. Both congratulated him when Margaret came home with her bachelor's degree in the spring of 1936.

She stayed with her father for a year and taught English at the black high school. Then night crashed down as black as coal dust. In the summer of 1937 she was stricken with meningitis and died in the same hospital where Sadie had told Sam 
good-bye.

Sam did not die with his daughter, nor did he wholly survive her death. He came and went and worked, a figure of immense dignity and integrity, a staunch figure in his church. But he lived the rest of his days with a grief he could not shed, and the old flame of aspiration was never rekindled.

With the years the thick seam of coal in the ridges about Fleming played out, as did Sam and a whole generation of miners. More than a decade has passed since he was buried in the little cemetery next to Sadie and Margaret, and the ancient coal-camp house where he lived so many lonely years now stands silent and empty. The desegregation decision of the Supreme Court closed the doors of the school he worked to build, and vandals reduced it to a shattered wreck. Sam had put little white markers at the graves of his wife and daughter but no one ever got around to marking his own. Perhaps a coal shovel thrust in the earth like a bayoneted rifle over the bones of a fallen hero would be appropriate for such a man. 
The Mountain, the Miner, and the Lord

1. What were the chief difficulties which Sam had to overcome to achieve his goal of educating Margaret?

2. What is scrip? Why did Sam react so angrily to being paid in scrip? Why was the company short of cash?

3. At the end of the story, Sam is referred to as a fallen hero. Did his community recognize him as a hero? Does he fit the traditional concept of a hero? Why or why not?

4. Find the following words in the story. Write the sentence containing each word. Define it from context. Look it up in the dictionary to see if your definition is correct. Write a sentence of your own using each word.

accommodating

apprehensive

cataclysmic

condescension

incredulity

fiscal

integrity

ornately

quiescent

solicitous 


\section{RON SHORT (1945- )}

Singer, actor, and playwright, Ron Short has encouraged deeper understanding and improvement of the quality of life in his native southwest Virginia.

A graduate of Clinch Valley College in Wise, Virginia, Short has devoted himself to public service, first as an employee of the Appalachian Regional Commission, later in community health programs, with the Federal Agency on Aging, and as administrator of the Highlander Research Center. At present, he is a creative director for Roadside Theatre.

June Appal has recorded his songs in an album Cities of Gold. The Roadside Theatre production Pretty Polly is based on his story. He sings and acts in his plays South of the Mountain and Leaving Egypt, Roadside productions that have toured America and Europe for the last 15 years.

This excerpt from South of the Mountain lets us listen to a mountain family talk about change. Eb, Mabel, and Thad enjoy their Chrysler, but they watch other progress and question its value.

From South of the Mountain (Song: "Wedding Bell Waltz")

\section{"Thad and Mabel"}

Mabel: $\quad$ Mommy didn't much want me to get married. 
Said I was too young, but I thank mostly she jist didn't want me to leave home, I wuz a big help to her. But, the first minute I laid eyes on Thad, I knowed he wuz gonna be the man I married.

Eb: When Thad and Mabel first got married they didn't have nothin'. They lived with us, me and Ma and $\mathrm{Pa}$. By that time all my brothers and sisters wuz married, wouldn't nobody home except me. But there ain't no way two families can live under the same roof. I don't care how good you git along, it ain't the natural thang to do. But he didn't have no job and no money. He wuz twenty and she wuz fifteen and they didn't know nothin.

Mabel: I wuz a Dutton fore I got married....

Eb: $\quad$ Her Daddy wuz from over round Skeetrock. He wouldn't from around the South of the Mountain.

Mabel: I wuz born in a coal camp over in Kentucky. Mommy's first husband died in the war, W.W.I, he didn't die in battle, he died of diptheria in Georgia somewhere. Mommy married Daddy and then they moved into Pike County, Kentucky, and Daddy went to work in the coal mines. Lotta people wuz going to work in the coal mines. That coal camp wuz jist about the most exciting place in the whole world, but Daddy couldn't stand it, and that last man that got killed in the mines my Daddy rode out with the body and that's the last time he ever went in. He said there had to be a better way to make a living, so we packed our few thangs in a sled and come back over the mountains.

Thad: $\quad$ Atter we got married, I tried to find work. Worked on the N.Y.A. and W.P.A. fer a little while but them jobs didn't last long. 
Mabel: I uz twelve year old when Daddy died. Mommy already had a job cause Daddy had been sick all summer before he died. Now, it was hard fer a woman to get a job. It wuz some kind of relief program. She made 94 cents a day sewing clothes fer people on welfare and you know, her a widow with six youngins she couldn't git one stitch of them clothes fer her own family. But my people wuz proud people, I guess is what you'd call it, cause we never let on if we didn't have something or nother and that wuz alright cause nobody knowed nothing about it. I didn't know till I started school, that ever' body didn't live like we did. There wuz very few that wuz different, but them that were wuz cruel. I don't know how you can have a dozen youngins and ten of em are pore and two ain't but them two can make the other ten feel bad. What I thought was the best eating in the world was an egg and a piece of corn bread fer lunch, but you know I'd go up in the hills behind the school and hide and eat that cornbread cause they' $\mathrm{d}$ make fun of you fer eating cornbread and not branging biscuits. But, to me, that was the best eatin' ever wuz. That was better than anythang I coulda took to school. Hit wouldn't bother me a bit in the world now, but it did then.

Thad: I shunned the coal mines as long as I could. I always kinda dreaded gettin started in 'em. I jist didn't like the idea of goin underground. I guess I'd been walkin round on top of it too long. But, that's all the work there wuz around, ceptin farming and I knowed where that would get you.

Mabel: In the coal camp they was houses on each side of the holler and the houses wuz connected.

Thad: One great big row of houses on one side

Mabel: and one great big row of houses on the other, 
340 Moving Mountains: Struggle of the Coal Industry

Thad: all under one roof.

Mabel: There wuz no seperation between the buildings,

Thad: jist walls.

Eb: It saved the coal company money by not having to have walls and a roof fer each house.

Jist one big long house.

Thad: One side wuz called the Titanic

Mabel: and one wuz called Noah's Ark.

Thad: Right down at the end of all them houses wuz a big company store.

Mabel: There wouldn't no hospital but they wuz a doctor's office.

Thad: All furnished by the company,

Eb: but they got ever cent of it back. Cause they wouldn't let you git ahead.

Thad: The coal company furnished the housing, electricity, they had the commissary for the food, but they took it out a yore pay,

Eb: and they paid you so little hit wouldn't much more than a labor camp.

Mabel: You talk about a raggedy, black bunch a youngins from fightin' through that coal camp from one end to the other in the coal dust in the summertime and all the mud in the wintertime. From hand to mouth, they jist lived.

Thad: They'd go to the store each day and buy what they 
could draw in scrip fer that day's work.

Mabel: Then they'd go back the next day. They'd buy a pound a soup beans and cook'em

Thad: and go the next day

Mabel: cause the man had to work the next day fer to get some more scrip.

Eb: I've heerd people say they'd rather do anythang than hoe corn

Thad \&

Mabel: So that's what they done.

Eb: It wuz hard to tell when they wuz working and when they wouldn't.

Mabel: But people follered it and lived with it right on up.

Thad: Up to that time, in the mountains people had never been that close to where people wuz a makin' some money.

Eb: They wouldn't but one man that I remember everbody kinda talked about as having any money and that wuz old man Henry Whitt. He had got shell shocked in the Army, during Worlds War One, I reckon, and he drawed a pension. Seemed to me like it wuz about thirty dollars a month and that wuz total disability. But Henry kept a bull. Wouldn't many people had enuff money where they could afford to buy a bull, and when you took your cow down there to Henry, I mean to his bull, that'd cost you a dollar, that is if she got with calf, otherwise it didn't cost you nothin'. But, they wouldn't many people that had that kinda steady income. 
Mabel: We started kinda fixing the house up, him with regular income. Linoleum, curtains, a new couch, thangs like that. He wuz making good money, but it wuz hard work.

Thad: They wuz somethin funny bout the whole thang right there from the start, best I could figure. They needed all this coal to generate all this power but I have shot many a cut coal with a breast auger. That wuz a drill where there was no power whatsoever. You cranked her by hand. You'd drill, shoot and load your own coal for a dollar a car, nothin' fer the rock and you handled as much rock as coal. You didn't use nothin' but a pick and a shovel, sweat and muscle.

Eb: When Thad first started working in them mines tole me he figgered he'd jist git a little money ahead and git out, but he never did seem to git money ahead.

Mabel: Till we got the refrigerator you couldn't keep nothin' fresh. We'd keep milk and butter in the root cellar but in the summer it wouldn't keep long. You had to can or pickle ever thang you raised. You couldn't keep leftovers, you eat 'em or they wuz fed to the animals. We'd never had ice. After we got the refrigerator, we'd jist make ice water cause it wuz so good. I made ice cream for the kids. Used to you could buy this mix from the store and make ice cream in the ice trays. That refrigerator shore made thangs a lot easier.

Thad: We used carbide lights then. It was a pretty rough go.

Eb: $\quad$ Hits a wonder they hadn't been a lot more men killed than there wuz. Said sometimes the roof wuz so low you couldn't even take a drink settin up. 
Thad: Lots a times you had to lay down on you side so you could tilt yore head back. But that smoke from the dynamite wuz worse, that stuff'd make you so sick.

Eb: There wouldn't enough air in the mines to push it out.

Thad: Give you a headache to where lots of times you'd have to come out jist fer the like of air. No dust control, coal miners eat the dust. You couldn't see yore hand before you or nothin' else with all that dust.

Eb: I don't know why it didn't kill a feller in thirty days.

Mabel: With a electric stove you can cook a meal in half the time it takes on a woodstove. When we got ours there was a special deal where you got a electric mixer too. I always liked to bake and this made it so much easier you wouldn't believe it. They come out with cake mixes that most cases was better than cakes baked from scratch. Canned biscuits too. We didn' like 'em too much, but, I bought 'em ever now and then.

Eb: First car in our family, I reckon he bought it.

Thad: It was a Chrysler, which jist about put us in the pore house, deeper than we wuz. I give $\$ 75$ fer it. That wuz the most money I'd ever had.

Eb: Hit wuz worth maybe 75 cents.

Thad: Yeah, I'd been better off without that Chrysler.

Mabel: I've seed him come in with his clothes froze stiff on his body where he'd worked in them water holes, got wet, then come outside. Then, when he could git a ride, ride home in the back of a truck in the middle of winter. I've seen him come in, 
where I could have cried he looked so pitiful. But even still it was better than not having a job at all. You had to make it one way or another. But I always vowed if ever there was anyway that I could get him out of them mines that I was going to do it.

Thad: Shore it wuz dangerous, everybody knowed that. I've seen it fall and I've had it to fall around me. I wuz loadin' one day and looked up and seen the shimmer on the top. I started to run and a big slab come down and the coal car caught it. That wuz all that kept it from ketching me. You constantly lived with that. It wuz jist a way of life. You didn't question it. They wouldn't no other work around. Tried not to thank that much about it. You didn't run out asking fer help. A job wuz all you asked fer.

I got ulcers though and never could git rid of 'em long as I wuz in the mines. Kept a vomiting and vomiting, couldn't eat nothin. Atter John L. and the union come in we got medical benefits so went over to see this doctor in Harlan. He took some Xrays and run a bunch a tests on me and he tole me, "Go hunt you a job outta them mines. You git out of 'em and stay out of 'em, if you want to live."

(SONG)

Eb: I never did marry. Lived at home all my life. I coulda married, I reckon, but never did. I stayed here with Ma till she died. Seemed kinda funny atter all them years, not having nobody to nag at me, tell me what to do. I used to hide out in the hayloft and read. I'd go off fer the barn like I's going to work and come dinner she'd blow the steer horn fer me to come home. I'd come to the house and eat, then go back and read. Wouldn't nothin fer me to do. We hadn't tended a big crop in years. Even put the "bakker" lotment into soil 
bank. Hell, if they pay me not to grow it, I won't. Chickens and a garden's all we had, but she acted like we's still raising crops and clearing new ground. She knowed we wouldn't but she jist couldn't stop. I don't reckon she couldn't remember not having somethin to do. It ain't what you got, it's how much money it's worth. Well I don't reckon I can live like that. I never have and I ain't gonna start now.

The rest of 'em has gone off someplace or other. I'm the only one left here, so I guess I can do what I want to. I don't want to go back and I don't want to go on neither. I guess I'm stuck in between. Least ways, I know where I'm at.

(SONG)

Thad: $\quad$ Ma and Eb set there on the creek and they didn't have nothing but it never seemed to bother 'em fer one minute. Atter $\mathrm{Ma}$ died $\mathrm{Eb}$ jist lived in his own world. Me and my family moved off into a real different world. I've thought about it and thought about it, whether they could a done any better or was jist willing to settle fer what they had.

Mabel: They's a difference in needin' and wantin'. It's harder to want thangs and not have 'em. If you've never tasted steak you're not any poorer fer not having it, but if you go out ever day and watch these other people eating steak you're gonna begin wandering atter while what it would be like to try some yourself. Then when you begin to want stuff like that and can't afford it, that is pore. When you have to do without the thangs you want, then you are pore.

Thad: But Ma and Eb wuz happy. I know that. They wuz home. I never tried to live up to nobody 
else's standards. I took what money I made and tried to do what I thought was best for my family. I got ahead a dime at a time. But I never thought I'd have to leave my home. Whenever I had to go off fer work, I never intended to stay. Of course when I wuz a young man hit was a big adventure but then it got to be a necessity of life. I reckon, it wuz always temporary in my mind. There's some people who has roots I reckon and there's some people who don't. I never did want to live no place else cept in the mountains. But I've come to believe everbody needs a place to come home to. But I don't know as you can always find home the way you left it. It seems instead of coming back home you carry a little more of it away with you each time you leave, till finally they ain't nothing to come home to no more. There's things we loose and there's thangs we learn, living in the times we all grow up in.

(SONG)

\section{South of the Mountain}

1. Mabel, Thad, and Eb describe many changes through dialogue. What are some of the biggest changes taking place? Have these changes improved the quality of their lives?

2. Discuss Mabel's ideas about "needin' and wantin"' given at the end of the selection. How do Mabel and Thad differ from $\mathrm{Ma}$ and $\mathrm{Eb}$ in their "needin' and wantin'"? 


\section{GEORGE ELLA LYON (1949 - )}

George Ella Lyon was born and reared in Harlan, Kentucky. She earned her B.A. from Centre College and her Ph.D. from Indiana University where her studies concentrated on Virginia Wolfe.

Her poetry has appeared in various literary journals. She has published one play, Braids, and a chapbook, Mountain. Her first children's book, Father Time and the Day Boxes, was published by Bradbury Press in 1985. She teaches at the University of Kentucky.

This poem speaks out against the indignity of strip mining. 
348 Moving Mountains: Struggle of the Coal Industry

\section{Stripped}

I was humming "Mist on the Mountain" and shelling peas

I was figuring board feet

I was carting off stones and quilting lettuce and thinking about a baby growing ripe inside

I was voting

I was lifting pain

out by the roots,

the bread indoors

breathing beneath a thin towel,

when a D-10 came

and rolled me off the front porch.

\section{Stripped}

1. Does this poem depict the destructive nature of strip mining in a realistic way? Explain.

2. Should the last two lines be interpreted literally or figuratively?

3. Why do you think the poet devotes more of the poem to what she was doing when the bulldozer came than she does to what the bulldozer was doing? 
Lee Howard is a narrative poet and short story writer from eastern Kentucky. She earned both her B.A. and M.A. degrees from George Washington University.

She has published in Southern Exposure, Mother Earth News, and Laurel Review. A collection of narrative poems, The Last Unmined Vein, gives voice to the working people and evokes their sense of place.

In the following poem the speaker tells why he won't sell the mineral rights to his land. 


\section{The Last Unmined Vein}

Now my daddy and me we used to dig a little coal out of that vein across the bottom Just a pick and shovel and what could be wheelbarrowed out of there was all that was took and didn't hurt nothing and kept a fire real good and that's it but that ain't what they got in mind They wanting to make steel in Ohio, turn on the lights in New York City and heat houses in Detroit Shoot-I don't know a soul in the whole state of Michigan but that ain't really it It ain't my business what they do with it but this farm and everything that's in it is plenty my concern

\section{The Last Unmined Vein}

1. To whom does the pronoun they refer to in this poem?

2. What is the son's individual concern? Is this a selfish concern? Explain 


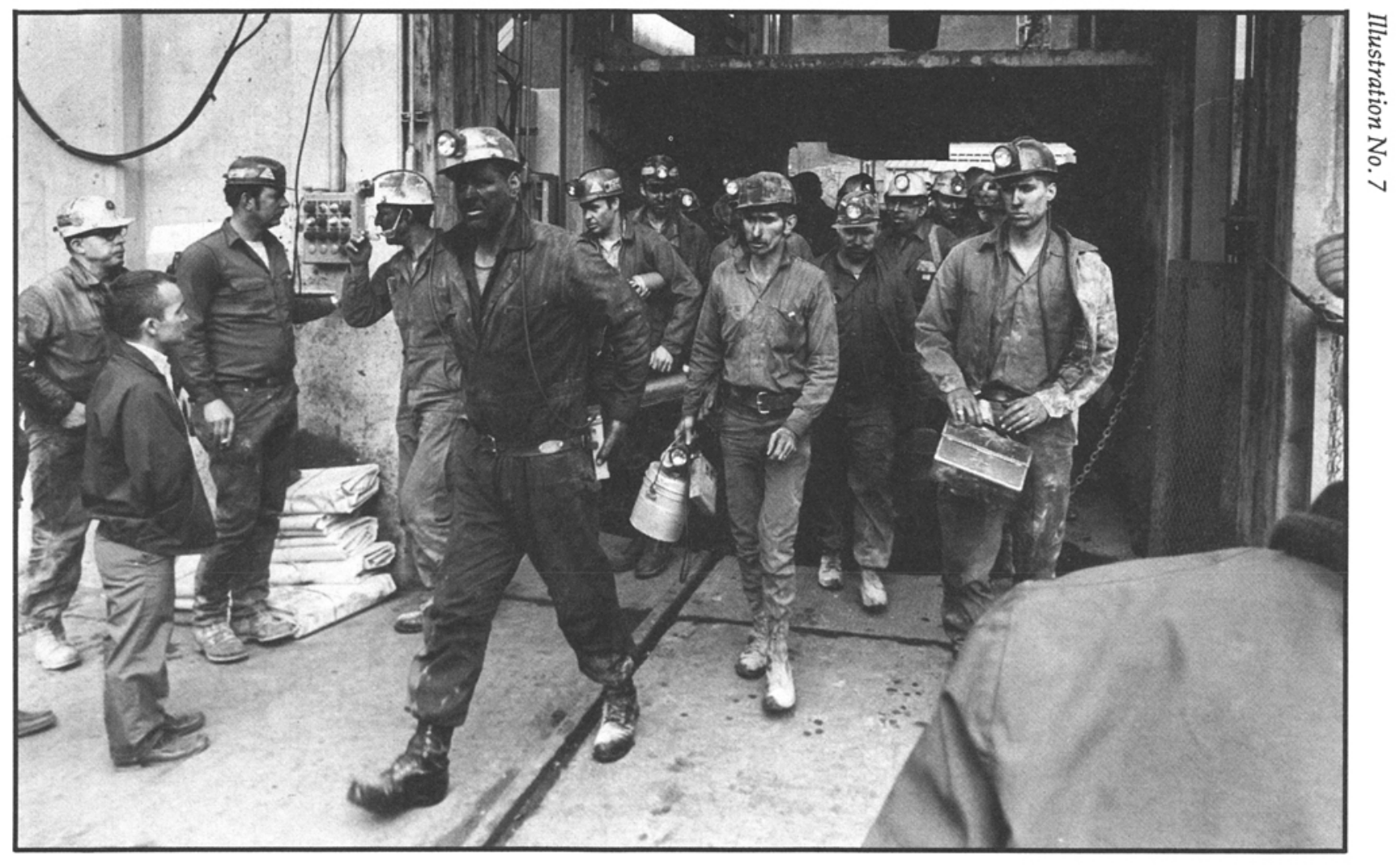

薑 


\section{EDWIN HOFFMAN (1918- )}

Born in New York and educated at City University and Columbia, Edwin Hoffman has taught history in South Carolina and West Virginia.

A contributor to history journals, he has also published three books. In them he claims to present "narrated dramatic episodes in which groups of Americans struggled for justice and a better life...."

This chapter from Fighting Mountaineers chronicles the resistance to strip-mining by residents of eastern Kentucky.

\section{Strippers, No!}

How citizens of the eastern Kentucky coal fields resisted the depredations of the strip miners in the protest-filled sixties (1965).

An elderly woman in a little frame house at the head of Sassafras Creek heard the din of a big bulldozer as it bit into soil nearby. The woman, Mrs. Bige Ritchie, hastened to her porch and called out to the operator of the machine, "Don't go there. There's a graveyard there." The man on the tractor climbed down and went to look. He came back to assure Mrs. Ritchie that he would not disturb the family plot. But then a second man arrived, concerned about the delay. When told of the 
graveyard ahead, he said, "I'll be damned if I won't take it through there!" He climbed up to the seat of the bulldozer and proceeded to tear up the little burial ground. Moments later, a small coffin was turned up and shoved over the hillside. Mrs. Ritchie watched the coffin of her infant son roll down the slope. Strip mining had reached her land. She felt powerless in the face of the power that the bulldozer represented. So did her fellow mountain people in 1960 in impoverished Knott County, Kentucky.

Much of Appalachia was then the land of the rural poor. The very name, Appalachia, had become a synonym for unrelenting poverty. Coal towns were dying, and the region was becoming depopulated by a steady exodus to the industrial cities of the Midwest. Those left behind in the hills and hollows of the more remote counties were largely a dispirited people, despairing of effecting improvement in their lives.

Poorest of all Appalachians were those who lived in the Cumberland Highlands of eastern Kentucky. Fewer than half the families had an income of as much as three thousand dollars a year. Less than four percent had incomes of ten thousand dollars or more. Unemployment was double the national average, and almost one third of the people were receiving public assistance. Mechanization of deep mining, the competition of strip mining, and the increased use of oil and natural gas had greatly reduced the demand for coal miners. By the sixties the United Mine Workers of America had lost most of its Kentucky membership to unemployment and nonunion mines. Agriculture no longer offered meaningful opportunities in the steeply sloped and often depleted lands of the Cumberland Highlands. With "coal or dole" the normal choices, and coal jobs so few, half the population of Knott and surrounding counties had fled the worsening poverty. Most of those left behind were the elderly and others least able or inclined to compete for the jobs in the auto, rubber, and steel industries to the north.

By 1964 Washington had "discovered" Appalachia and its Kentucky highlands. President Johnson announced the "War 
on Poverty"-community-action programs, VISTA workers, and Appalachian Volunteers, food stamps, freeschool lunches, jobless-father programs, retraining programs, and more. Unfortunately, the War on Poverty served only to create the illusion of solving problems; it generated no new industries or new jobs in the region. People became increasingly dependent on welfare programs and on the local politicians who controlled the doling out of the federal millions.

In addition to the badly sagging economy and the acute poverty of the people, they had to contend with the voracious monster that had risen in their midst-strip mining. Mountains that had made the people feel rich in beauty if not in income were assaulted with giant bulldozers, augers, power shovels, and dynamite. Sometimes the ridge tops were sheared off to reach the coal seams, with the "spoil" of dirt, rock, and uprooted trees pushed over the mountainsides. Sometimes steep "highwalls" were cut on the slopes, creating cliffs up to ninety feet high through which the augers drilled laterally into the exposed coal seams. The power shovels and the huge coal trucks moved along the "bench," as the wide area scraped out below the highwall was called, to load the coal and carry it off the mountain face. This ravaging of the land was accompanied by the constant blasts that loosened the coal, the screech of steel against the embedded mineral, and the roar of the powerful engines. When the mammoth trucks carried their loads over the crumbled mountain roads, the reverberations could be sensed in all the homes along the way, and were a raucous reminder of the gouging of a once lovely environment. Even when the last gashing and scarring were done, when the strippers had torn away the last of the coal, the streams still ran yellow and turgid with the acid outwash of the devastated land, and each rain brought fresh mudslides to the valley floors. The companies never called these activities strip mining. Their euphemism was "surface mining," and they spoke of "developing" the land.

Ten thousand or more acres of eastern Kentucky highlands were stripped away each year, with none of the wealth going 
to those who lived upon the land. Many years before, the ancestors of these mountain folk had been persuaded to sign socalled broad-form deeds, by which they gave up mineral rights on their land, usually for fifty cents per acre. These deeds gave the new owners of the minerals in the subsoil freedom to remove coal deposits even though the mining destroyed the surface of the land. A 1953 court decision stated that the owner of the surface of the land need not be compensated for damages to it since a ruling in favor of those living on the land would cause undue hardship to the coal companies. A 1960 decision held that, as long as the surface property was not damaged maliciously, the strip-mining companies could not be penalized even if boulders from their operations fell on homes below the mined land. Nor did the law require any significant reclamation of the stripped mountains, and most cuts were made on slopes so steep that the token reclamation efforts were usually washed away.

The companies laying waste to the land were usually subsidiaries of such supercorporations as United States Steel, Bethlehem Steel, Ford Motor, and International Harvester. But even when the mining companies were Kentucky owned, they based their mining practices not on the well-being of the region but on the demand for cheap coal by the Tennessee Valley Authority. The TVA, which had been created in New Deal days to revive the economy and uplift the people of the vast Tennessee River watershed principally by the generation of inexpensive hydroelectric power, was now producing more power from coal than water. By the sixties most coal mined in eastern Kentucky was bought by TVA. Its pricing policies made deep mining far less profitable than strip mining, and it showed little concern for the havoc this mining was doing to the coalfields. Appalachia had long been a quasi-colony of the wealthier parts of America, whose investors greatly profited from the coal and timber of its mountainsides. Now, ironically, the biggest exploiter of the land and the people had become the quasi-public Tennessee Valley Authority.

The acceleration of strip mining that came with exception- 
ally large TVA contracts in 1965 ignited in the mountain people resentment that had been smoldering for years. When the bulldozers that were decapitating the whole ridge above Clear Creek in Knott County reached the land of a marine serving in Vietnam, his stepfather, the elderly carpenter and coffin maker Dan Gibson, hastened to the top of Honey Gap to stop the strippers. He sat down before the machines with a loaded rifle across his knee and told their drivers that they had no right to strip a man's land while he was overseas fighting for his country. They decided not to defy Dan Gibson and his .22caliber gun. The coal company then swore out a warrant charging him with breach of the peace and threatening with a deadly weapon. When a group of state and county police arrested him, he gave himself up peaceably. The next day the bulldozers were confronted by a large group of mostly grayhaired men and women, some armed, who stood and sat at the property line. Again the strippers were temporarily frustrated, and the people of Clear Creek were encouraged to make further efforts to save their land.

In the Clear Creek district, there was a "community-action" organization which had been recently formed to encourage popular participation in the War on Poverty. Following the appearance of the bulldozers, the organization became the nucleus of a people's war on strip mining. Some eighty worried and agitated landowners met at the Knott County courthouse in Hindman on June 1, 1965, to plan resistance. They heard reports that the coal companies were issuing rifles to their machine operators and truck drivers to fight off the landowners. Noting that Dan Gibson and his neighbors had faced the strippers with guns and that one woman had stopped strippers with a pistol while her husband was away on jury duty, some mountaineers proposed resorting to armed resistance to defend their property. Others urged that the group learn from the civil rights movement and use such nonviolent tactics as sit-ins and lie-ins to stop the ruination of their land. Perhaps, they could get results if they sat in at the governor's mansion in Frankfort or on the blue-grass lawns of the coal operators' 
estates in central Kentucky. Upon noting that the state agencies and some professors at the University of Kentucky spoke of planting elderberry bushes on the stripped, bare land, someone suggested sarcastically that the university could make eastern Kentucky a second Garden of Eden by turning strippers loose and then covering all the hills with the bushes. Perhaps the devastation could be hidden beneath a coating of elderberry jam.

A week later an even larger group of citizens, drawn from Knott, Letcher, and Perry counties, met in Hindman. Most of the one hundred and twenty-five participants were small landowners, and some were also teachers, merchants, farmers, or coal miners. The inspirational leader of the group was the patriarchal Dan Gibson. To shouts of approval he declared, "We are dead certain not going to let them come on our land and tear it up. We will do whatever it takes to stop the strip miners." They agreed to found a new organization, the Appalachian Group to Save the Land and the People (AGSLP). A Knott County high school teacher, Leroy Martin, was elected chairman. Co-chairmen were high school principal Eldon Davidson from Letcher County and Commonwealth Attorney Tolbert Combs from Perry County.

At the early AGSLP meetings the sentiment for militant protest was high. People who had never spoken at meetings as well as those accustomed to public speaking rose to voice their anger. The members heard from Mrs. Susan Ritchie of Clear Creek how she and her family had been "just sitting here watching for the hill to come off of us." In the middle of one night they were forced to flee their home when they heard a mud slide begin at the top of the nearby mountain where stripping had been done. Others at the meeting told of a one-armed coal miner who came home from a training program of the War on Poverty to find his home buried beneath a great landslide. How could people expect to continue living in eastern Kentucky, speakers asked, if earth and debris might come down at any moment and cover up the gardens, crop fields, lawns, graveyards, and everything else? 
Leroy Martin told why he had joined the movement and was willing to lead it. "I am a schoolteacher. I got a loan and remodeled my house, and now they are coming around back of it and, as far as the laws are concerned at the present time, we can't even collect damages. They can dump trees and rocks down on us and push our house on into the creek, and the only way we can collect damages in this state is to let the creek fill up and the water get up and flood us. I live way up the hill and I don't think I will ever be flooded." He charged that "they have got all these laws set up for the operators against the man who owns the land, and we don't have a chance, we don't have a chance."

Eldon Davidson added that the land agents of the coal companies "are among the most hated men in eastern Kentucky. They go ahead and buy the timber for a pittance and make tremendous profit off of it because the people know they must sell. They know it's going to be covered up if they don't sell. Then they make it worse by bragging how they cheated these poor people who sold their timber to them."

Most eloquent at the early meetings of the AGSLP was an attorney, Harry Caudill. He already enjoyed a national reputation as the "mountain muckraker." His writings and speeches decried strip mining and other ways in which his neighbors were being exploited. To him the towering highwalls cut by strip mining near his Letcher County home could be compared to "monstrous yellow serpents" looping themselves around the mountains. "We have to decide," he told his fellow members, "to work for life or death. There is no longer any time to discuss, ponder, and confer. Eastern Kentucky has come down to the moment in history when people are going to decide whether to live in eastern Kentucky as free men or be driven out of here as a bunch of dispossessed paupers." He went on to say that the coal companies were "going to rip this country apart and takeall the wealth," and that his fellow mountaineers were "being pauperized by a barbarous process that would not be tolerated in any truly civilized corner of this globe."

The Appalachian Group to Save the Land and the People 
set itself five immediate goals. It would raise funds to enable Homer Ritchie to sue a coal company whose stripping activities had left his home covered with mud and trees when what seemed like an entire mountainside had slid onto it a few days before. It would also raise money to carry a suit to the Supreme Court of the United States, if necessary, to test the validity of the old broad-form deed. It would collect signatures on petitions to the governor requesting immediate enforcement of strip-mining laws already on the books, and it would send petitions and telegrams to President Johnson asking for federal action. Finally, it would organize a big motorcade to the state capital to seek relief from the governor and the legislature.

Attorney Caudill filed suit for Homer Ritchie in the Knott County Circuit Court. Heargued that the coal companies gave up their right to harm and destroy surface improvements without payment when over many years they had silently allowed the landowners to make improvements on the leased lands. The equity of the surface owners was being violated even if the law was not, he noted, and he asked the court to declare the surface owners' lands off limits to the operators on the ground that the broad-form deeds signed years ago should not apply to strip and auger mining.

The coal operators were not idle in opposition. Prior to the Ritchie suit they had succeeded in getting the Knott County court to enjoin nineteen landowners from interfering with operations which residents claimed were causing debris to wash down upon their property. The restraining order was to be enforced by the state police, and the operators won permission to arm employees as protection against irate landowners. The operators also circulated rumors that the aroused citizens were "radicals" and "communists." Lawyer Caudill was a special target of their disfavor. They accused him of being against stripping for the money he would make as champion of the cause. To this charge Caudill replied, "If I were after the money, I would be on their side. That's where all the money is." Friends warned him of threats against his life, but he continued to be outspoken. 
Also candid and unsparing was a little weekly newspaper in his home town, the Whitesburg Mountain Eagle. The coal industry saw it as a scandal sheet filled with lies, but most mountain people viewed it as a forthright paper that published news and editorials most other newspapers feared to print. The Mountain Eagle called the stripping crisis more important to the state than the Vietnam war, and it labeled TVA "a disgrace to the nation" in its "insane quest for cheap coal." An editorial on June 10 quoted a middle-aged woman, who feared not only the burial of her mountain home but the violence of the strippers. "I pray to God every day," she said, "that my man will let them take our land and our home and not try to stop them. I'm even afraid for him to go to court." The strip-mine firms, she went on, "have hired the worst gun thugs in Eastern Kentucky to make us give them our land. They will help kill us if we don't. What can we do? They've got the courts and the state police and the killers on their side." The editorial then quoted another mountain woman who spoke in the same vein. "The men in this country are all scared to death. They know that if they do anything our homes will be dynamited or they will be stopped on the road some night and shot to death."

The mountain folk were apprehensive, but many were not "scared to death" of resisting the strippers. When the Appalachian Group to Save the Land and the People held its second meeting on June 16 in the gymnasium of Carr Creek High School, one hundred and seventy men and women showed up. They quickly decided to organize a protest caravan of cars to the state capital. Harry Caudill announced that he had spoken to Governor Edward Breathitt and had secured his promise to meet with them. The meeting proceeded to plan ways to get hundreds of concerned eastern Kentuckians to Frankfort. AGSLP would canvass the hollows of four counties for more people to join the "march." Trucks with loudspeakers would go through the towns recruiting for the motorcade. A special effort would be made to get local politicians to join the march, in the expectation that the governor would be impressed and the charge of "communist" could 
be most easily refuted. After the organizing got under way the governor became fearful. He called Henry Caudill and said, "I'm afraid these people will scare my girls. They are not used to mountain people." Caudill assured him that the governor's secretaries had nothing to fear from the demonstrators.

Early Tuesday morning, June 22, the caravan began the one hundred and eighty-mile trip to Frankfort. The sign-bedecked old cars and beat-up trucks, cleaned up for the occasion, carried almost two hundred mountaineers. Some had never before left the Cumberland Highlands. The protesters wore the best clothes they had. Some of the men wore suits and ties, and some women had on store-bought dresses. Other men wore short-sleeved shirts with denim pants, or overalls, and some women had on well-worn homemade dresses.

At the capital they picketed with spirit. They chanted slogans and carried signs as they waited to see Governor Breathitt. Dan Gibson's placard read, "ELDERBERRY BUSHES! HOW STUPID CAN PEOPLE GET?" One poster declared, "PEACEFUL, YES. COMPLACENT, NO! NO! NO!" Another said "STRIPPING IS DESTRUCTION."

Despite his promise to see them, the governor put them off with the excuse that he was too busy. When New York Times reporter Ben Franklin persuaded him to see a delegation of the mountain people, however, fourteen filed into his office. Half were the politicians who had joined the movement, invariably of the older generation since the younger officeholders would not risk antagonizing the coal companies. The delegation included a county judge, two Commonwealth attorneys, and a state senator. Also among the fourteen were Leroy Martin, Eldon Davidson, Dan Gibson, and Harry Caudill. The group presented the governor with a six-page letter asking him to act promptly since the tempo of stripping was accelerating. "The ruin of the whole region can be accomplished in another decade unless it is stopped now," the letter warned. A special session of the Commonwealth's legislature was declared to be urgently needed to enact a law prohibiting strip mining on any mountainous terrain where restoration of the soil could not be 
accomplished in a reasonable time. The law should stipulate that stripping be permitted only upon the written permission of the owner of the surface of the land.

Herman Ritchie, a self-taught TV repairman with the words, "TROUBLESOME CREEK ELECTRONICS" displayed in red letters on the back of his gritty work shirt, told the governor that his wife and two children "had to get out or be killed when they started rolling rocks on the house, splitting the trees up behind us on the slope-one rock rolled right up to the front porch." William R. Smith, Knott County banker and candidate for Congress, said that strip mining was going to wreck his home and the county. Mud would congest the creeks and cause flooding two or three times a year. Governor Breathitt looked at Smith as if he and the whole delegation were grossly exaggerating, and other speakers seemed to be equally ineffective.

Then the group brought in Mrs. Bige Ritchie. The governor said, "Auntie, I want you to sit here at my desk and tell me anything you want to say." The old woman told him how the strip miners had come and dug up the family graveyard, pitched the coffin of her child over the hill, and bulldozed the coal out. She said she thought her heart would break when she saw that little casket roll down the slope. The governor changed his demeanor after hearing her, and became much more concerned about the plight of the mountain people.

After meeting with the delegation, Governor Breathitt spoke in the Health Department auditorium to all the protestors. He told them he was now deeply concerned about what he had heard that day. He promised that the current law would be effectively enforced, and a strong effort would be made to get a better national or interstate policy to regulate strip mining. Since his stand would depend on how well the current law could be expected to work, he would have "a top level, fact-finding group" from in and out of state government "do an objective, hard, fact-finding job" to determine this. If the study showed the present law to be inadequate, he would recommend to the next legislature one that could do the job. 
The only applause the unsmiling mountaineers gave him was for his last statement.

When the governor finished speaking, his natural resources commissioner presided over a heated discussion between the state's mining officials and the protesters. The commissioner was roundly booed when he claimed to have made efforts to regulate stripping in Knott County. Gurney Norman, a Hazard newspaper reporter, rose to tell him, "I don't think anyone has respect for what you are doing because they don't have respect for the law as it stands." Norman asked repeatedly for information on specific law violations by strippers, but got no direct replies. At day's end most mountaineers left Frankfort angrier than when they had come, but Harry Caudill was encouraged. "I think it is the first time that the state administration has heard the voice of the people," he told the reporters covering the protest. "Up until today, they've heard the voice of the coal operators and an occasional garden club member and editorial writer. This is the beginning of a mass voice of the people."

Nor was the voice of the coal operators muted at that time. While the governor was meeting with the victims of the strip mining, a three-day symposium on "surface mining" had begun in the nearby city of Lexington. This state-sponsored meeting was attended largely by leaders of the strip-mining industry who spoke as if their activities were an unmixed blessing to the state. They professed to reclaim the land, with the head of the Kentucky Oak Mining Company lashing out at critics of its Knott County mining for taking "isolated cases of irresponsibility" and making it appear that this was the pattern of the industry. The Louisville Courier-Journal, the state's leading newspaper, described the gathering as "a defense meeting of the stripping industry," a parade of speakers "allegedly concerned with conservation" who made strip mining sound "as cute and pretty as an outing of nature lovers." Federal officials at the symposium, the newspaper added, talked of stripping and reclamation as though it were "a droll and delightful way of planting trees." The state commissioner of natural resour- 
ces also saw no evil. He claimed that the law was being strictly enforced. "If anyone knows of any violation of the law anywhere, let him come forward," he urged. "We will take action at once and punish all offenders, big and small."

Perhaps most self-serving of all was Aubrey Wagner, chairman of the board of the Tennessee Valley Authority, the largest consumer of coal in the world and the primary customer of the coal operators at the meeting. "Strip mining, while it is going on, looks like the devil," he admitted, "but what comes out of it has done wonders for this area. If you look at what those mountains were doing before this stripping, they were just growing trees that were not being harvested." Now there are hundreds of miles of haul roads and mountain cuts on the Kentucky landscape. They constituted a new resource, giving access for fire control and future recreational purposes. Wagner added that stripping was the only way to get at much of Kentucky's coal, that it was safer than deep mining, and it could lower power costs to consumers. While he said not a word about the devastation inflicted on mountain home owners, he did say that TVA might require "scientific conservation practices" in the future, and he favored a federal stripmine law that would have other states do as much for reclamation as Kentucky required.

At this industry-dominated symposium, the handful of mountaineers who had come from the demonstration in Frankfort were almost inundated by the tide of the industry and government apologists. But the protesters had already influenced Edward Breathitt. When the governor spoke, he held out the promise of reform. He would call upon the legislature to outlaw strip mining, he said, "if erosion, flooding, and pollution are the inevitable consequences of such mining." He warned the operators that, unless honest reclamation was begun in a hurry, "an outraged public" would demand prohibition of the industry. "We don't intend," he cautioned, "to permit this industry or any other industry to destroy the beauty of Kentucky's countryside or the usefulness of its earth for future generations." 
A week later the mountain people realized another benefit from their caravan to the capital when the governor paid a surprise visit to some stripping operations in Knott and Perry counties. He had never before seen the ravages of strip mining and was deeply moved. He talked to some affected landowners, picking homes at random. Mrs. Claudia Hall of Clear Creek told him, "Everyone around here feels the same way as we do. The people around here are getting touchy about it." Frank Fugate, an old Regulator Baptist preacher, made it clear to the governor just how "touchy" they could get if their homes were jeopardized by the operators. "Whenever they came on me," he said, "I put 'em off. We didn't want to go to violence, but I knew we were ready for it."

At the end of his dusty tour, the governor announced that he would act at once to relieve the problems of the landowners. Fully convinced of the gravity of their problem, he would ask the attorney general to intervene on the side of the mountaineers in the court case testing the broad-form deeds, and he would be willing to go to the United States Supreme Court if necessary to get a favorable ruling. He would also confer with the TVA officials to persuade them to pay strip-mining operators an additional twenty cents per ton for reclamation efforts. He condemned the TVA for making high profits "at the expense of ruined hillsides, poisoned streams, dead woodlands, devastated farms, breeding grounds for mosquitoes, and eradicated wildlife." Concurring with the criticisms of those who had demonstrated, he said, "I am not referring to the present, half-hearted attempts to get fruit trees or elderberry bushes or pine seedlings to grow in the thin, acid soil left at the mining sites."

A week later Governor Breathitt came back for a second visit to the coalfields. He was met at a road-building ceremony in Isom in Letcher County by pickets from the Appalachian Group to Save the Land and the People. They carried "SAVE OUR LAND" signs so that he would know that the people would not be satisfied with mere words of sympathy. The Mountain Eagle observed that the downtrodden mountain 
whites were learning something from the Blacks in the civil rights movement-that you could expect nothing if you suffer in silence. In late July the governor followed through on another promise when the state asked the Knott County court to prohibit strip or auger mining "where such operation results in peril to members of the public, its streams, roads, and other public property."

During the following months the movement continued its protests and organizing. Money for a legal defense fund was raised at meetings in run-down schools and churches, often from the sale of honey, eggs, and cakes. One hundred Letcher County residents formed a branch of AGSLP. Their president, Lundy Adams, warned that he was a peaceful man, "but a man can be pushed just so far." Some mountaineers may not have been so peaceful. Dynamite blasts went off in the hills, blowing up mining machinery. One night a half million dollars' worth of equipment was destroyed. On another night someone hid in the bushes and wounded the driver of a bulldozer with a shotgun blast. It was never learned who committed these acts of violence. The spokesmen for the operators implied that the protesters were to blame, while AGSLP said that the explosions were set off by company personnel, using the old dodge of blowing up worn-out machinery to collect the insurance on it.

Harry Caudill was especially active in behalf of the cause. Speaking of one local stripper, the Virginia Coal and Iron Company, which Caudill said made higher profits in 1964 than any other American company, he remarked, "We don't want to put them out of business. We would like to civilize them." He sharply contrasted such wealth with the poverty of the people. Seven thousand people in Perry County, he noted, drew food stamps. At the head of Lott's Creek, he pointed out, "hundreds of thousands of dollars' worth of illegally large coal trucks loaded with millions of dollars' worth of untaxed coal pass a two hundred-dollar schoolhouse."

But it was neither Harry Caudill nor the leaders of the Appalachian group, but a gray-haired widow up a Clear Creek 
hollow who became the best symbol and voice of the movement to resist the strip mining. When Mrs. Ollie Combs-the Widow Combs, as she came to be known throughout Kentucky and even to readers of the New York Times-repeatedly halted the stripping above her little cabin by lying down in front of a big yellow bulldozer and was hauled off to jail for her resistance, the cause of the mountain folk became real to many people who had been unmoved by the statistics and rhetoric on the rape of the mountains.

The confrontation was a consequence of a partial victory won by the protest movement in the fall of 1965. The state announced that somewhat stricter regulations would go into effect on December 18, regulations that would outlaw strip mining on slopes steeper than 33 degrees. Operators hastened to mine the steep slopes as much as possible before the deadline. The Caperton Coal Company's equipment began biting into the ridge above the tiny home of Mrs. Combs and her family. An early member of AGSLP, she was sixty-one, very recently widowed, and living with five sons, who ranged in age from thirteen to twenty-seven. The Combses' four-room wooden cabin, with its typical old washing machine and wringer on the porch, lay squeezed between a one-lane dirt road and a steep, wooded hillside. That little house represented the family's life savings, and Mrs. Combs was determined that no avalanche of rocks, dirt, and trees would fall upon it. The coal company promised her that they would only bulldoze out a road above her to reach coal past her property, and it would compensate her for any damages done to her property, but she had no faith in a stripper's word.

It was late November when Mrs. Combs first heard the throaty growl of a bulldozer on the ridge above her home. She sat in her rocking chair before the sulfurous coal fire in her little fireplace, listening for the machine to come close to her land. When it did, she put on her frayed jacket and well-worn heavy shoes, picked up her walking stick, and set out for the ridge top. There she lay down in front of the great blade of the bulldozer and sharply told the driver that he had better not try 
to strip her land. He stopped the machine, and the company quickly secured an injunction from the county court forbidding interference with its operations. This did not faze Mrs. Combs. She again lay down before the bulldozer. On two successive days she was arrested, the second time with two of her sons.

At the time of her later arrest, Bill Strode, a photographer from the Louisville Courier-Journal, followed her up the ridge to photograph her defiance. He had an opportunity to witness her exceptional courage. "I don't bother nobody," she told the bulldozer operator, "but you come into our homes." After stopping the machine she built herself a fire of twigs so that she might weather the elements as long as necessary while she blocked the way. Soon Sheriff Oliver Hylton, a deputy, and two state troopers arrived and ordered the widow and her sons to leave.

"You promised me you wouldn't come back up here," the sheriff said.

"No, I didn't," she replied.

She then turned to William "Buck" Caperton, the head of the strip-mining company, who had joined them. "I told you to get out and stay out."

"I've never been stopped yet," he told her.

"I've not either," was her sharp reply.

Caperton remarked that he was doing nothing "contrary to the law."

"But it's contrary to me," Mrs. Combs retorted.

"Well, you can't please everybody," he said. "We are going through." hard."

"Just go off and leave us alone," Mrs. Combs said. "We live

After another hour, seeing that she would not budge, Sheriff Hylton arrested her and her sons. With the sheriff taking her by the legs and a state trooper holding her under the arms, they carried her limp body down the slope to a police car. It was then that the sheriff ordered the news photographer to stop taking pictures. Strode refused. He was arrested on a "John Doe" warrant for trespassing. The sheriff tried to seize 
his camera. The two men struggled for it, the strap broke, and Strode was able to beat the sheriff to the fallen camera and keep it. A few moments later, he removed the film, put it into the finger of his glove, and hid the glove inside his trousers. All those arrested were taken to the county jail. The Combses were soon let out on bail, and the charges were dropped against Strode. A day later photographs and a vivid story told Kentuckians of the "Widow vs. Bulldozer" and asked "Has Mrs. Combs Beaten Strip Miners?"

Back home on the morning following her most recent arrest, Mrs. Combs again heard the rumble of the bulldozer. She trudged out to do battle again, with the newsman right behind her. This time the coal company had armed guards on the ridge, but she walked right past them to await the machine. The guards threatened and cursed the photographer as he snapped pictures, and then they threw rocks at him. The bulldozer never came. Mrs. Combs left to go with her two sons to the courthouse in Hazard to stand trial for contempt of court. Outside the building William Sturgill, president of the coal company that held a controlling interest in Caperton Coal, declared that he was ready for a showdown. He would not be deterred by barriers thrown up by protesting landowners, for the company had the law on its side.

The Combses had a brief trial before the Knott County Police Court. Mrs. Combs sat quietly on one side of the dimly lit courtroom, serene, yet firm in her determination.

Had she done anything "violent" or "mean" while protesting, her lawyer asked.

"No sir," she replied. "I didn't even think of it."

"Have you ever been in trouble?" he asked.

"I've never been in trouble. Never been in jail." she said. "I just want to live out my life in my hollow and be left alone. I don't want to see my home ruined. It's all I got left."

The mine company's lawyer told the judge, "We don't want to keep bringing in people for contempt. I don't know if these people know what a restraining order is."

"There would be no trouble," the Combses' lawyer snapped 
back, "if you would take these nefarious machines off those mountains and silently steal away."

The judge found Mrs. Combs and her two sons guilty. $\mathrm{He}$ imposed no fine on them but sentenced each to twenty hours in jail. The Caperton attorney reminded the judge that this sentence would run into Thanksgiving Day and urged a two-day delay. The Combses' lawyer added that Mrs. Combs had a paralytic son back home. The judge was adamant. They would go to jail immediately.

Widow Combs accepted confinement as serenely as she had her trial. When Thanksgiving Day came, she and the other inmates were served an early dinner of chicken and dumplings. When the Combses were released, their return home was a joyous occasion. Some fifty friends and neighbors met them at the head of the hollow. Mrs. Combs laughed and then she cried. Neighbors brought food in pots and dishes for a second Thanksgiving dinner. After eating she wrapped her head in a brightly colored scarf and made her way up the ridge where the stripping had been attempted. This was a symbolic journey. She would not have to fear rearrest, for the judge had ordered Caperton Coal to cease its activities on the slope above her cabin.

On the following day Governor Breathitt told the press, "I want the Widow Combs and all other Kentuckians whose home and farms are threatened with destruction to know I am on their side." He added, "I urge and expect all citizens of Kentucky to obey the law." The governor accused the operators of "provoking and causing these disturbances" and urged them to "desist from further insistence on their pound of flesh" until the proper scope of the broad-form mineral-rights deeds was decided in the courts. If the courts disagreed with his position in support of the landowners, he would seek new legislation protecting them from the strippers. Meanwhile, he appointed a special counsel to plead the mountaineers' case, and he ordered the state police not to aid in the arrest of protesters unless he told them to do so. A day later he issued an emergency order temporarily prohibiting almost all steep-slope mining. 
Progress in resistance was also being made in the courts. The suit of Leroy Martin, argued by Harry Caudill and a government attorney, met with preliminary success. Instead of throwing out the case, as had previously been the custom, the Knott County circuit judge agreed to consider whether the owner of the surface land continued to have rights despite their having been signed away in broad-form deeds fifty or more years ago. In the case of the Martin property, an illiterate mountaineer and his wife had signed away their rights with marks of " $X "$ in 1903. Strip mining, of course, was unheard of then, and Caudill argued that it could not have been imagined that huge machines would devastate the land. The operators' reply to the suit was essentially that a contract had been agreed to, and it was still binding.

On January 4, 1966, Governor Breathitt addressed the opening session of the Kentucky General Assembly. He urged the lawmakers to give top priority to the control of strip mining and to civil rights. The present mining law, he noted, was ineffective in protecting the people and their land. Kentucky should be "second to none" in its concern for the earth, just as "Kentucky is second to no state in the richness of it." That same day a bill to do what the governor proposed was introduced into the legislature. It would eliminate the rugged contours left by customary stripping practices and so lessen landslides and scarring of the mountains. The bill called for terraced back fills to be created in "bench-type" operations. Dirt and rock removed was to be piled back on the bench instead of being pushed over the mountainside. The state would be empowered to disapprove stripping where the operation was a hazard to homes, schools, churches, cemeteries, commercial buildings, public roads, streams, and lakes. Operators could not deposit debris outside the mining area or place it where erosion might move it outside the area.

Battle lines quickly formed. The coal companies attacked the bill in costly newspaper and radio advertisements and were evidently raising a large fund to defeat it. The anti-stripping movement replied by charging that the coal and railroad com- 
panies were raising huge sums to influence the lawmakers. The companies strongly denied the allegations of the protesters. Implications that the companies were raising money for bribery were called "the worst blow yet."

Despite the industries' money and influence, the anti-stripping forces prevailed. In an unusual move, Governor Breathitt made a personal appearance on the floor of the lower house to persuade the legislators to pass the bill. By January 27 it passed both houses by overwhelming votes. The new law would take effect in June. The coal operators moaned that it would put them out of business.

A second anti-strip mining bill remained under consideration. This one proposed to amend the broad-form deeds to make them inapplicable to strip mining. Mrs. Combs was one of the witnesses who testified for the bill. As she sat on a folding chair with her hands on her lap and spoke movingly for the change, she so impressed the legislators and the press that the bill became known as the "Widow Combs bill." However, this time the coal interest and their allies in the steel, railroad, chemical, and oil industries prevailed. The bill was tabled on March 2 , and two attempts to revive it were unsuccessful.

Even though the "Widow Combs bill" failed to pass, the newly enacted restrictions on strip-mining procedures appeared to be a significant victory for the Appalachian Group to Save the Land and the People, and for the Bige Ritchies and Ollie Combses who had taken on roles so uncommon for mountain women. The test of a law is its enforcement, however, and the 1966 law was simply not enforced in a manner that would end the raping of the mountains. Kentucky soon got a new governor who lacked the zeal that Edward Breathitt had acquired in the last months of his term of office. The courts also disappointed mountain protesters. The circuit court ruled in the Martin case that the broad-form deeds were legal, that the strip mining could continue, and that the coal companies must make fair payment for any damages done to surface property. Both sides appealed the ruling. Briefs supporting the appeal of Leroy Martin were filed by the Sierra 
Club and the Kentucky Civil Liberties Union, as well as by AGSLP and the state of Kentucky. The Kentucky Court of Appeals was not persuaded. On June 21, 1968, it sustained every argument of the strippers. They were free to mine land without the owner's consent, and they did not have to pay that owner for any damages done to the surface of the land.

While the Martin case was going through the courts, some mountaineers warred on the operators with guerrilla tactics. In the summer of 1967 a $\$ 50,000$ diesel-powered shovel of the Kentucky Oak Mining Company, the defendant in Martin's suit, was blown up one night at a Knott County strip mine. Then $\$ 300,000$ worth of machinery of the Tar Heel Coal Company was dynamited on Lost Creek. So many bullets were fired at this operation that some company bulldozers were equipped with armor plate. These violent protests may have been the last, frustration-filled acts of the now dispirited mountaineers. For by 1967 there was an erosion of leadership. Leroy Martin and Eldon Davidson left Knott County for better jobs. Mrs. Combs changed her mind and let the coal company pay her a small sum to strip her land. The Appalachian Group to Save the Land and the People disbanded, and more and more of the mountains were lost to the bulldozers, augers, and other huge, noisy earthmovers. The recent ravages of the strip miners could best be seen above the cabin of the Widow Combs-now a raw hillside, an ugly highwall, and dirt spilled down below it. Only Harry Caudill remained as a spokesman for the cause, to chronicle the dying of the Cumberland Highlands and to keep alive the conservationist spirit.

\section{Strippers, No!}

1. Could you call the conflict between the mountaineers and the strippers a struggle between right and wrong? Or did both groups have legitimate reasons for what they were doing? 
374 Moving Mountains: Struggle of the Coal Industry

2. When Governor Breathitt finally visited Knott County and Perry County, what was his reaction to what he saw? What were the results of his visit?

3. Of the protesters you have read about in this section, which one impressed you most? Give reasons.

4. Define the following terms as they are used in the context of this selection: dole, high wall, broad-form deed, reclamation, restraining order. 


\section{RICHARD HAGUE (1947- )}

Poet Richard Hague, born and reared inSteubenville, Ohio, now makes his home in Cincinnati. Educated at Xavier University in Cincinnati, he received his B.S. and his M.A. in English in 1972. He began teaching in 1969 at what is now Purcell Marion High School, where he is Chairman of the English Department. He has taught at Edgecliff College and Xavier University and was the 1984 Writer-in-Residence at the Kentucky Institute for Arts in Education at the University of Louisville.

Hague is the author of three collections of poetry: Crossings, A Week of Nights Down River, and Ripening, for which he received the Co-Poet of the Year award by the Ohio Poetry Day Association. He has served several times on the staff of the Appalachian Writers Workshop at the Hindman Settlement School and in 1985 presented a poetry lecture series on public access cable for the Arts and Humanities Resource Center in Cincinnati.

The following poem from Ripening is one of many Hague has written about his feelings about the coal mining life. 
376 Moving Mountains: Struggle of the Coal Industry

\section{In the Woods Beyond the Coalfields}

I have come here to forget

the red god of my fathers

and the furnace of his meaning.

But the breeze is westerly today,

hauls Ohio's sin here.

Far across these Seven Ranges

float smoke and coalspill,

which to this summer's common wounds

upon the hillside, field,

and pond

apply no healing poultice.

The large, warm woman of the air

who once nursed blighted fox

and split-branched tree,

who once spilled health like splashed weeds

up and down these hollows,

hobbles now, hammered

in the darkness of old mines.

I will not find her here,

but I cannot go away.

In a dream that stalks me like my doom,

I fall through all the daylight

of these woods,

and stumble upstream toward the mine,

where the rotting bodies

of my fathers

slip like nightmares

from black slag. 
In the Woods Beyond the Coalfields

1. What has the poet "come here to forget?"

2. Discuss the dream in the last stanza and its possible interpretation. 


\section{COMPOSITION TOPICS}

1. Look around you for any personal injustice or controversial public issue which you might protest. In a composition state the problem; then give your point of view and defend it with reasons.

2. The selections in this chapter show the effects of coal mining on the people. Choose the selection which most clearly illustrates the conflict. Make up a name and address of a coal company and write letter to its president. Clearly state the conflict and suggest a solution that will consider the needs of the people and the needs of the company.

\section{ACTIVITIES}

Add to your book an account of any member of your family who felt injustice and did something about it.

Write the military history of the people on your family tree who have served in the armed forces. Include the following:

1. Name, rank, serial number, and branch of service

2. Dates of service

3. Was it war time or peace time? Name the war.

4. To what states and countries did the service take your family member?

5. What was his or her job in the service?

6. Was he or she in a major battle? Tell about it.

7. Illustrate with a photograph of the person in uniform. 


\section{CHAPTER 6}

\section{The Change Hits Home: The Challenge to Tradition and Values}

The same questions asked about the southern United States may be asked of Appalachia. Is Appalachia extinct? Have television, new industry, federal programs, emigration, and immigration blended the region with the rest of America? Is it now rich, industrialized, cosmopolitan, and, consequently, indistinguishable in the American mainstream? Or, as some scholars contend, has America become what Appalachia once was? A November 2, 1986, New York Times article quotes John Gaventa of the Highlander Center as saying: "Instead of modernizing the mountaineer...we are now mountainizing the moderns. The mainstream of America is joining us."

The largely rural culture of Southern Appalachia has now run head-on into the fast-paced, high-tech life of the 1980s. The old ways - the values, religious beliefs and practices, and the very pace of everyday life-are being chal- 
lenged. Older people remembering the Appalachia of earlier times are keenly aware of this rapid change.

It can be argued that this pressure to change, this homogenizing of America into one landscape of malls, fastfood restaurants and highways, is the impetus for most of the writing in Appalachia today. All of the selections in this second section are, finally, about change and how we cope with it. 


\section{JESSE STUART (1907-1984)}

Jesse Stuart was born in W-Hollow, a farm near Riverton, Kentucky, and attended a one-room country school which he later used as the setting for some of his stories. He worked to put himself through Lincoln Memorial University in Tennessee, where James Still and Don West were among his classmates. He studied for one year at Vanderbilt University, although he did not complete his master's degree. There he wrote his autobiography, which he later published as Beyond Dark Hills.

Stuart taught school, including stints at the American University in Cairo, Egypt, and at the University of Nevada. He also farmed, worked in industry, and served in the Navy. During 1962 and 1963, he was the American specialist abroad for the Bureau of Education and Cultural Affairs.

Jesse Stuart received many honors and awards in all areas of writing. He burst on the American literary scene in 1934 with Man With A Bull-Tongue Plow. His poetry, short stories, and juvenile fiction were very popular and appeared frequently in magazines and literary journals. His short story collection Men of the Mountains won the Academy of Arts and Sciences Award, and the novel Taps for Private Tussie received the Thomas Jefferson Memorial Award in 1943.

The National Education Association selected The Thread That Runs So True as the best book of 1949. Stuart also received 
the Academy of American Poets Award in 1961. Kentucky honored him with the designation of Poet Laureate in 1954.

"Split Cherry Tree" is about changes in education and how education changes the lives of people.

\section{Split Cherry Tree}

"I don't mind staying after school," I says to Professor Herbert, "but I'd rather you'd whip me with a switch and let me go home early. Pa will whip me anyway for getting home two hours late."

"You are too big to whip," says Professor Herbert, "and I have to punish you for climbing up in that cherry tree. You boys knew better than that! The other five boys have paid their dollar each. You have been the only one who has not helped pay for the tree. Can't you borrow a dollar?"

"I can't," I says. "I'll have to take the punishment. I wish it would be quicker punishment. I wouldn't mind."

Professor Herbert stood and looked at me. He was a big man. He wore a gray suit of clothes. The suit matched his gray hair.

"You don't know my father," I says to Professor Herbert. "He might be called a little old-fashioned. He makes us mind him until we' re twenty-one years old. He believes if you spare the rod you spoil the child. I'll never be able to make him understand about the cherry tree. I'm the first of my people to go to high school."

"You must take the punishment," says Professor Herbert. "You must stay two hours after school today and two hours after school tomorrow. I am allowing you twenty-five cents an hour. That is good money for a high school student. You can sweep the schoolhouse floor, wash the blackboards, and clean windows. I'll pay the dollar for you."

I couldn't ask Professor Herbert to loan me a dollar. He never offered to loan it to me. I had to stay and help the janitor and work out my fine at a quarter an hour. 
I thought as I swept the floor, "What will Pa do to me? What lie can I tell him when I go home? Why did we ever climb that cherry tree and break it down for anyway? Why did we run crazy over the hills away from the crowd? Why did we do all of this? Six of us climbed up in a little cherry tree after one little lizard! Why did the tree split and fall with us? It should have been a stronger tree! Why did Eif Crabtree just happen to be below us plowing and catch us in his cherry tree? Why wasn't he a better man than to charge us six dollars for the tree?"

It was six o'clock when I left the schoolhouse. I had six miles to walk home. It would be after seven when I got home. I had all my work to do when I got home. It took Pa and me both to do the work. Seven cows to milk. Nineteen head of cattle to feed, four mules, twenty-five hogs, firewood and stovewood to cut, and water to draw from the well. He would be doing it when I got home. He would be mad and wondering what was keeping me!

I hurried home. I would run under the dark, leafless trees. I would walk fast uphill. I would run down the hill. The ground was freezing. I had to hurry. I had to run. I reached the long ridge that led to our cow pasture. I ran along this ridge. The wind dried the sweat on my face. I ran across the pasture to the house.

I threw down my books in the chipyard. I ran to the barn to spread fodder on the ground for the cattle. Ididn't take time to change my clean school clothes for my old work clothes. I ran out to the barn. I saw Pa spreading fodder on the ground to the cattle. That was my job. I ran up to the fence. I says, "Leave that for me, Pa. I'll do it. I'm just a little late."

"I see you are," says Pa. He turned and looked at me. His eyes danced fire. "What in th' world has kept you so? Why ain't you been here to help me with this work? Make a gentleman out'n one boy in th' family and this is what you get! Send you to high school and you get too onery fer th' buzzards to smell!"

I never said anything. I didn't want to tell why I was late 
from school. Pa stopped scattering the bundles of fodder. He looked at me. He says, "Why are you gettin' in here this time $o^{\prime}$ night? You tell me or I'll take a hickory withe ${ }^{1}$ to you right here on th' spot!"

I says, "I had to stay after school." I couldn't lie to Pa. He'd go to school and find out why I had to stay. If I lied to him it would be too bad for me.

"Why did you haf to stay atter school?" says Pa.

I says, "Our biology class went on a field trip today. Six of us boys broke down a cherry tree. We had to give a dollar apiece to pay for the tree. I didn't have the dollar. Professor Herbert is making me work out my dollar. He gives me twenty-five cents an hour. I had to stay in this afternoon. I'll have to stay in tomorrow afternoon!"

"Are you telling me th' truth?" says $\mathrm{Pa}$.

"I'm telling you the truth," I says. "Go and see for yourself."

"That's jist what I'll do in th' morning, says $\mathrm{Pa}$. "Jist whose cherrytree did you break down?"

"Eif Crabtree's cherry tree!"

"What was you doin' clear out in Eif Crabtree's place?" says $\mathrm{Pa}$. "He lives four miles from th' county high school. Don't they teach you no books at that high school? Do they jist let you get out and gad over th' hillsides? If that's all they do I'll keep you at home, Dave. I've got work here fer you to do!"

"Pa," I says, "spring is just getting here. We take a subject in school where we have to have bugs, snakes, flowers, lizards, frogs, and plants. It is biology. It was a pretty day today. We went out to find a few of these. Six of us boys saw a lizard at the same time sunning on a cherry tree. We all went up the tree to get it. We broke the tree down. It split at the forks. Eif Crabtree was plowing down below us. He ran up the hill and got our names. The other boys gave their dollar apiece. I didn't have mine. Professor Herbert put mine in for me. I have to work it out at school."

"Poor man's son, huh," says Pa. "I'll attend to that myself in th' mornin'. I'll take keer o' 'im. He ain't from this county nohow. I'll go down there in th' mornin' and see 'im. Lettin' 
you leave your books and gallivant all over th' hills. What kind of a school is it nohow! Didn't do that, my son, when I's a little shaver in school. All fared alike, too."

"Pa, please don't go down there," I says, "just let me have fifty cents to pay the rest of my fine! I don't want you to go down there! I don't want you to start anything with Professor Herbert!"

"Ashamed of your old Pap are you, Dave," says $\mathrm{Pa}$, "atter th' way I've worked to raise you! Tryin' to send you to school so you can make a better livin' than I've made.

"I'll straighten this thing out myself! I'll take keer o' Professor Herbert myself! He ain't got no right to keep you and let the other boys off jist because they've got th' money! I'm a poor man. A bullet will go in a professor same as it will any man. It will go in a rich man same as it will a poor man. Now you get into this work before I take one $o^{\prime}$ these withes and cut the shirt off'n your back!"

I thought once I'd run through the woods above the barn just as hard as I could go. I thought I'd leave high school and home forever! Pa could not catch me! I'd get away! I couldn't go back to school with him. He'd have a gun and maybe he'd shoot Professor Herbert. It was hard to tell what he would do. I could tell Pa that school had changed in the hills from the way it was when he was a boy, but he wouldn't understand. I could tell him we studied frogs, birds, snakes, lizards, flowers, insects. But $\mathrm{Pa}$ wouldn't understand. If I did run away from home it wouldn't matter to Pa. He would see Professor Herbert anyway. He would think that high school and Professor Herbert had run me away from home. There was no need to run away. I'd just have to stay, finish foddering the cattle, and go to school with Pa the next morning.

I would take a bundle of fodder, remove the hickory withe band from around it, and scatter it on rocks, clumps of green briers, and brush so the cattle wouldn't tramp it under their feet. I would lean it up against the oak trees and the rocks in the pasture just above our pigpen on the hill. The fodder was cold and frosty where it had set out in the stacks. I would carry 
bundles of the fodder from the stack until I had spread out a bundle for each steer. Pa went to the barn to feed the mules and throw corn in the pen to the hogs.

The moon shone bright in the cold March sky. I finished my work by moonlight. Professor Herbert really didn't know how much work I had to do at home. If he had known he would not have kept me after school. He would have loaned me a dollar to have paid my part on the cherry tree. He had never lived in the hills. He didn't know the way the hill boys had to work so that they could go to school. Now he was teaching in a county high school where all the boys who attended were from hill farms.

After I'd finished doing my work I went to the house and ate my supper. $\mathrm{Pa}$ and Mom had eaten. My supper was getting cold. I heard $\mathrm{Pa}$ and Mom talking in the front room. Pa was telling Mom about me staying in after school.

"I had to do all th' milkin' tonight, chop th' wood myself. It's too hard on me atter I've turned ground all day. I'm goin' to take a day off tomorrow and see if I can't remedy things a little. I'll go down to that high school tomorrow. I won't be a very good scholar fer Professor Herbert nohow. He won't keep me in atter school. I'll take a different kind of lesson down there and make 'im acquainted with it."

"Now, Luster," says Mom, you jist stay away from there. Don't cause a lot $o^{\prime}$ trouble. You can be jailed fer a trick like that. You'll get th' Law atter you. You'll just go down there and show off and plague your own boy Dave to death in front o' all th' scholars!"

"Plague or no plague," says $\mathrm{Pa}$, "he don't take into consideration what all I have to do here, does he? I'll show'im it ain't right to keep one boy in and let the rest go scot-free. My boy is good as th' rest, ain't he? A bullet will make a hole in a schoolteacher same as it will anybody else. Hecan't do me that way and get by with it. I'll plug 'im first. I aim to go down there bright and early in the mornin' and get all this straight! I aim to see about bug larnin' and this runnin' all over God's creation huntin' snakes, lizards, and frogs. Ransackin' th' 
country and goin' through cherry orchards and breakin' th' trees down atter lizards! Old Eif Crabtree ought to a-poured th' hot lead to 'em instead o' chargin' six dollars fer th' tree! He ought to a-got old Herbert th' first one!"

I ate my supper. I slipped upstairs and lit the lamp. I tried to forget the whole thing. I studied plane geometry. Then I studied my biology lesson. I could hardly study for thinking about Pa. "He'll go to school with me in the morning. He'll take a gun for Professor Herbert! What will Professor Herbert think of me! I'll tell him when Pa leaves that I couldn't help it. But Pa might shoot him. I hate to go with Pa. Maybe he'll cool off about it tonight and not go in the morning."

Pa got up at four o'clock. He built a fire in the stove. Then he built a fire in the fireplace. He got Mom up to get breakfast. Then he got me up to help feed and milk. By the time we had our work done at the barn, Mom had breakfast ready for us. We ate our breakfast. Daylight came and we could see the bare oak trees covered white with frost. The hills were white with frost. A cold wind was blowing. The sky was clear. The sun would soon come out and melt the frost. The afternoon would be warm with sunshine and the frozen ground would thaw. There would be mud on the hills again. Muddy water would then run down the little ditches on the hills.

"Now, Dave," says Pa, "let's get ready fer school. I aim to go with you this mornin' and look into bug larnin', frog larnin', lizard and snake larnin', and breakin' down cherry trees! I don't like no sicha foolish way o' larnin' myself!"

Pa hadn't forgot. I'd have to take him to school with me. He would take me to school with him. We were going early. I was glad we were going early. If Pa pulled a gun on Professor Herbert there wouldn't be so many of my classmates there to see him.

I knew that Pa wouldn't be at home in the high school. He wore overalls, big boots, a blue shirt and a sheepskin coat, and a slouched black hat gone to seed at the top. He put his gun in its holster. We started trudging toward the high school across the hill. 
It was early when we got to the county high school. Professor Herbert had just got there. I just thought as we walked up the steps into the schoolhouse, "Maybe Pa will find out Professor Herbert is a good man. He just doesn't know him. Just like I felt toward the Lambert boys across the hill. I didn't like them until I'd seen them and talked to them. After I went to school with them and talked to them, I liked them and we were friends. It's a lot in knowing the other fellow."

"You're th' Professor here, ain't you!" says Pa.

"Yes," says Professor Herbert, "and you are Dave's father."

"Yes," says $\mathrm{Pa}$, pulling out his gun and laying it on the seat in Professor Herbert's office. Professor Herbert's eyes got big behind his black-rimmed glasses when he saw Pa's gun. Color came into his pale cheeks.

"Jist a few things about this school I want to know," says Pa. 'I'm tryin' to make a scholar out' $n$ Dave. He's the only one out'n eleven youngins I've sent to high school. Here he comes in late and leaves me all the work to do! He said you's all out bug huntin' yesterday and broke a cherry tree down. He had to stay two hours atter school yesterday and work out money to pay for that cherry tree! Is that right?"

"Wwwwy," says Professor Herbert," I guess it is."

He looked at Pa's gun.

"Well," says Pa, "this ain't no high school. It's a bug school, a lizard school, a snake school! It ain't no school nohow!"

"Why did you bring that gun?" says Professor Herbert to Pa.

"You see that little hole," says $\mathrm{Pa}$ as he picked up the long blue forty-four and put his finger on the end of the barrel, "a bullet can come out'n that hole that will kill a schoolteacher same as it will any other man. It will kill a rich man same as a poor man. It will kill a man. But atter I come in and saw you, I know'd I wouldn't need it. This maul ${ }^{2}$ of mine could do you up in a few minutes."

Pa stood there, big, hard, brown-skinned, and mighty, beside of Professor Herbert. I didn't know Pa was so much bigger and harder. I'd never seen $\mathrm{Pa}$ in a schoolhouse before. I'd 
seen Professor Herbert. He always looked big before to me. He didn't look big standing beside of Pa.

"I was only doing my duty, Mr. Sexton," says Professor Herbert, "and following the course of study the state provided us with."

"Course o' study," says $\mathrm{Pa}$, "what study, bug study? Varmint study? Takin' youngins to th' woods. Boys and girls all out there together a-gallivantin' in the brush and kicking up their heels and their poor old Ma's and Pa's at home a-slavin' to keep 'em in school and give 'em a education! You know that's dangerous, too, puttin' a lot o' boys and girls out together like that!"

Students were coming into the schoolhouse now.

Professor Herbert says, "Close the door, Dave, so others won't hear.

I walked over and closed the door. I was shaking like a leaf in the wind. I thought Pa was going to hit Professor Herbert every minute. He was doing all the talking. His face was getting red. The red color was coming through the brown, weather-beaten skin on Pa's face.

"I was right with these students," says Professor Herbert. "I know what they got into and what they didn't. I didn't send one of the other teachers with them on this field trip. I went myself. Yes, I took the boys and girls together. Why not?"

"It jist don't look good to me," says Pa, "a-takin' all this swarm of youngins out to pillage $\mathrm{e}^{3} \mathrm{th}^{\prime}$ whole deestrict. Breaking' down cherry trees. Keeping' boys in atter school."

"What else could I have done with Dave, Mr. Sexton?" says Professor Herbert. "The boys didn't have any business all climbing that cherry tree after one lizard. One boy could have gone up in the tree and got it. The farmer charged us six dollars. It was a little steep, I think, but we had it to pay. Must I make five boys pay and let your boy off? He said he didn't have the dollar and couldn't get it. So I put it in for him. I'm letting him work it out. He's not working for me. He's working for the school!"

"I jist don't know what you could a-done with 'im," says 
$\mathrm{Pa}$, "only a-larruped 'im with a withe! That's what he needed!"

"He's too big to whip," says Professor Herbert, pointing at me. "He's a man in size."

"He's not too big fer me to whip," says Pa. "They ain't too big until they' re over twenty-one! It jist didn't look fair to me! Work one and let th' rest out because they got th' money. I don't see what bugs has got to do with a high school! It don't look good to me nohow!"

Pa picked up his gun and put it back in its holster. The red color left Professor Herbert's face. He talked more to Pa. Pa softened a little. It looked funny to see $\mathrm{Pa}$ in the high school building. It was the first time he'd ever been there.

"We were not only hunting snakes, toads, flowers, butterflies, lizards," says Professor Herbert, "but, Mr. Sexton, I was hunting dry timothy grass ${ }^{4}$ to put in an incubator and raise some protozoa."

"I don't know what that is," says Pa. "Th' incubator is th' new-fangled way o' cheatin' th' hens and raisin' chickens. I ain't so sure about th' breed o' chickens you mentioned."

"You've heard of germs, Mr. Sexton, haven't you?" says Professor Herbert.

"Jist call me Luster, if you don't mind," says $\mathrm{Pa}$, very casual like.

"All right, Luster, you've heard of germs, haven't you?"

"Yes," says $\mathrm{Pa}$, "but I don't believe in germs. I'm sixty-five years old and I ain't seen one yet!"

"You can't see them with your naked eye," says Professor Herbert. "Just keep that gun in the holster and stay with me in the high school today. I have a few things I want to show you. That scum on your teeth has germs in it." teeth!"

"What," says $\mathrm{Pa}$, "you mean to tell me I've got germs on my

"Yes," says Professor Herbert. "The same kind as we might be able to find in a living black snake if we dissect it!"

"I don't mean to dispute your word," says Pa, "but I don't believe it. I don't believe I have germs on my teeth!"

"Stay with me today and I'll show you. I want to take you 
through the school anyway! School has changed a lot in the hills since you went to school. I don't guess we had high schools in this county when you went to school!"

"No," says Pa, "jist readin', writin', and cipherin'. Wedidn't have all this bug larnin', frog larnin', and findin' germs on your teeth and in the middle o' black snakes! Th' world's changin'."

"It is," says Professor Herbert, "and we hope all for the better. Boys like your own there are going to help change it. He's your boy. He knows all of what I've told you. You stay with me today."

"I'll shore stay with you," says Pa. "I want to see th' germs off'n my teeth. I jist want to see a germ. I've never seen one in my life. 'Seein' is believin',' Pap allus told me."

Pa walked out of the office with Professor Herbert. I just hoped Professor Herbert didn't have $\mathrm{Pa}$ arrested for pulling his gun. Pa's gun has always been a friend to him when he goes to settle disputes.

The bell rang. School took up. I saw the students when they marched in the schoolhouse look at $\mathrm{Pa}$. They would grin and punch each other. Pa just stood and watched them pass in at the schoolhouse door. Two long lines marched in the house. The boys and girls were clean and well dressed. Pa stood over in the schoolyard under a leafless elm, in his sheepskin coat, his big boots laced in front with buckskin, and his heavy socks stuck above his boot tops. Pa's overalls legs were baggy and wrinkled between his coat and boot tops. His blue work shirt showed at the collar. His big black hat showed his graystreaked black hair. His face was hard and weather-tanned to the color of a ripe fodder blade. His hands were big and gnarled like the roots of the elm tree he stood beside.

When I went to my first class I saw Pa and Professor Herbert going around over the schoolhouse. I was in my geometry class when $\mathrm{Pa}$ and Professor Herbert came in the room. We were explaining our propositions on the blackboard. Professor Herbert and $\mathrm{Pa}$ just quietly came in and sat down for a while. I heard Fred Wurts whisper to Glenn Armstrong, "Who is that old man? Lord, he's a rough-looking scamp." Glenn 
whispered back, "I think he's Dave's Pap." The students in geometry looked at $\mathrm{Pa}$. They must have wondered what he was doing in school. Before the class was over, Pa and Professor Herbert got up and went out. I saw them together down on the playground. Professor Herbert was explaining to Pa. I could see the prints of Pa's gun under his coat when he'd walk around.

At noon in the high school cafeteria Pa and Professor Herbert sat together at the little table where Professor Herbert always ate by himself. They ate together. The students watched the way $\mathrm{Pa}$ ate. He ate with his knife instead of his fork. A lot of the students felt sorry for me after they found out he was my father. They didn't have to feel sorry for me. I wasn't ashamed of $\mathrm{Pa}$ after I found out he wasn't going to shoot Professor Herbert. I was glad they had made friends. I wasn't ashamed of Pa. I wouldn't be as long as he behaved. He would find out about the high school as I had found out about the Lambert boys across the hill.

In the afternoon when we went to biology $\mathrm{Pa}$ was in the class. He was sitting on one of the high stools beside the microscope. We went ahead with our work just as if $\mathrm{Pa}$ wasn't in the class. I saw Pa take his knife and scrape tartar from one of his teeth. Professor Herbert put it on the lens and adjusted the microscope for Pa. He adjusted it and worked awhile. Then he says: "Now Luster, look! Put your eye right down to the light. Squint the other eye!"

Pa put his head down and did as Professor Herbert said. "I see 'im," says $\mathrm{Pa}$. "Who'd a ever thought that? Right on a body's teeth! Right in a body's mouth. You're right certain they ain't fake to this, Professor Herbert?"

"No, Luster," says Professor Herbert. "It's there. That's the germ. Germs live in a world we cannot see with the naked eye. We must use the microscope. There are millions of them in our bodies. Some are harmful. Others are helpful."

Pa holds his face down and looks through the microscope. We stop and watch $\mathrm{Pa}$. He sits upon the tall stool. His knees are against the table. His legs are long. His coat slips up be- 
hind when he bends over. The handle of his gun shows. Professor Herbert pulls his coat down quickly.

"Oh, yes," says Pa. He gets up and pulls his coat down. Pa's face gets a little red. He knows about his gun and he knows he doesn't have any use for it in high school.

"We have a big black snake over here we caught yesterday," says Professor Herbert. "We'll chloroform him and dissect him and show you he has germs in his body, too."

"Don't do it," says Pa. "I believe you. I jist don't want to see you kill the black snake. I never kill one. They are good mousers and a lot $o^{\prime}$ help to us on the farm. I like black snakes. I jist hate to see people kill 'em. I don't allow 'em killed on my place."

The students looked at $\mathrm{Pa}$. They seemed to like him better after he said that. Pa with a gun in his pocket but a tender heart beneath his ribs for snakes, but not for man! Pa won't whip a mule at home. He won't whip his cattle.

"Man can defend hisself," says $\mathrm{Pa}$, "but cattle and mules can't. We have the drop on 'em. Ain't nothin' to a man that'll beat a good pullin' mule. He ain't got th' right kind o' a heart!"

Professor Herbert took $\mathrm{Pa}$ through the laboratory. He showed him the different kinds of work we were doing. $\mathrm{He}$ showed him our equipment. They stood and talked while we worked. Then they walked out together. They talked louder when they got out in the hall.

When our biology class was over I walked out of the room. It was our last class for the day. I would have to take my broom and sweep two hours to finish paying for the split cherry tree. I just wondered if Pa would want me to stay. He was standing in the hallway watching the students march out. He looked lost among us. He looked like a leaf turned brown on the tree among the treetop filled with growing leaves.

I got my broom and started to sweep. Professor Herbert walked up and says, "I'm going to let you do that some other time. You can go home with your father. He is waiting out there."

I laid my broom down, got my books, and went down the 
steps.

Pa says, "Ain't you got two hours o' sweepin' yet to do?"

I says, "Professor Herbert said I could do it some other time. He said for me to go home with you."

"No," says Pa. "You are goin' to do as he says. He's a good man. School has changed from my day and time. I'm a dead leaf, Dave. I'm behind. I don't belong here. If he'll let me I'll get a broom and we'll both sweep one hour. That pays your debt. I'll hep you pay it. I'll ast 'im and see if he won't let me hep you."

"I'm going to cancel the debt," says Professor Herbert. "I just wanted you to understand, Luster."

"I understand," says $\mathrm{Pa}$, "and since I understand, he must pay for his debt fer th' tree and I'm going to hep 'im."

"Don't do that," says Professor Herbert. "It's all on me."

"We don't do things like that," says $\mathrm{Pa}$, "we're just and honest people. We don't want somethin' fer nothin'. Professor Herbert, you're wrong now and I'm right. You'll haf to listen to me. I've larned a lot from you. My boy must go on. Th' world has left me. It changed while I've raised my family and plowed th' hills. I'm a just and honest man. I don't skip debts. I ain't larned 'em to do that. I ain't got much larnin' myself but I do know right from wrong atter I see through a thing."

Professor Herbert went home. Pa and I stayed and swept one hour. It looked funny to see $\mathrm{Pa}$ use a broom. He never used one at home. Mom used the broom. Pa used the plow. Pa did hard work. Pa says, "I can't sweep. Durned if I can. Look at th' streaks o' dirt I leave on th' floor! Seems like no work a-tall fer me. Brooms is too light 'r somethin'. I'll jist do th' best I can, Dave. I've been wrong about th' school."

I says, "Did you know Professor Herbert can get a warrant out for you for bringing your pistol to school and showing it in his office! They can railroad you for that!"

"That's all made right," says Pa. "I've made that right. Professor Herbert ain't goin' to take it to court. He likes me. I like 'im. We jist had to get together. He had the remedies. He 
showed me. You must go on to school. I am as strong a man as ever come out'n th' hills fer my years and th' hard work I've done. But I'm behind, Dave. I'm a little man. Your hands will be softer than mine. Your clothes will be better. You'll allus look cleaner than your old Pap. Jist remember, Dave, to pay your debts and be honest. Jist be kind to animals and don't bother th' snakes. That's all I got agin th' school. Puttin' black snakes to sleep and cuttin' 'em open."

It was late when we got home. Stars were in the sky. The moon was up. The ground was frozen. Pa took his time going home. I couldn't run like I did the night before. It was ten o'clock before we got the work finished, our suppers eaten. $\mathrm{Pa}$ sat before the fire and told Mom he was going to take her and show her a germ sometime. Mom hadn't seen one either. Pa told her about the high school and the fine man Professor Herbert was. He told Mom about the strange school across the hill and how different it was from the school in their day and time.

\section{Notes}

${ }^{1}$ withe: a slender branch

${ }^{2}$ maul: a heavy hammer used especially for driving wedges or piles; here Pa means his hand.

${ }^{3}$ pillage: to take or destroy property by open violence; to take unlawfully.

${ }^{4}$ timothy grass: a fodder grass with long, cylindrical spikes.

5 protozoa: one-celled microscopic animals.

${ }^{6}$ railroad: slang, to have someone imprisoned on false charges or without a fair trial. 
396 The Change Hits Home

\section{Split Cherry Tree}

1. How do Pa and Professor Herbert differ in their method of resolving conflict?

2. What is Dave's major worry in regard to his offense?

3. How does Pa's attitude toward Dave's punishment change after Pa's visit to school?

4. What basic truths about people are revealed in this story? 
FRED CHAPPELL 397

\section{FRED CHAPPELL (1936- )}

Fred Chappell has received praise, recognition, and critical acclaim, especially since the prestigious Bollinger Prize for Poetry was awarded to him in 1984 for his collection Midquest.

A graduate of Duke University, Chappell was born in Canton, North Carolina, to a family in the furniture business. He is a prolific writer with poetry, short stories, novels, reviews, and essays to his credit. His publications include his latest novel, I Am One of You Forever, and his most recent book of poetry, Source. Other titles by Chappell include Moments of Light (short stories), The World Between The Eyes , and The Castle Tsingal (poetry). He currently teaches at the University of North Carolina at Greensboro.

"Firewater" tells the story of a local historical celebration.

\section{Firewater}

Beneath the hairy hams hung from the hooks

Virgil Campbell talked in his grocery store:

"I just got back from the hundredth anniversary

Of Clay County. I have kinfolks that way,

They asked me out to see the spectacle. 
The local politicians-just to give you A notion-were calling themselves town fathers. So then I know something's bound to happen. If I had fathered a town I wouldn't brag About Hayesville. I mean, there's a matter of pride.

"First off, the usual stuff. Speeches crammed To the gullet with lies; sorghum-judging, Jam-judging, cake-judging, quilt-judging; ribbons Handed out to the grandmaws and the livestock. And then the square dance contest. (I got to say The Hiawassee Stompers can flat out clog some ...) I was rolling with it right along, Had me a laugh and a sip or two... J.T., They had them a beauty queen. That gal was healthy, I'm here to tell you, and ought to season out As comfortable as a split rail fence And keep as many varmints off your ground... Maybe my taste is running sophisticated, I've lived too long in the wicked city of Pigeon Fork.

"The main attraction, besides the knife- and fist-fights, Was the Clay County Hundredth Grand Parade, Celebrating their most famous products.

-Now what's Clay County famous for?"

My father said.

$$
\text { "Moonshine," }
$$

"And everybody knows it, But who'd've thought they'd parade it on the street? Damn if they didn't. They went up Standing Indian And told Big Mama to build a model still And put it on a wagon and ride with it. Ten years they've been trying to prosecute That woman for running shine, and out of the blue They come up hat in hand to ask her sweetly To waltz it down Main Street in broad daylight. 
"And she said Yes. The notion had to tickle her

Once they got past her mean suspiciousness.

So there she was. I saw her. Swear to Jesus.

Sitting in a rocking chair on a wagon

By the cooker, and the copper worm

Strung down behind her, and smoke just boiling out

Pretty as you please. A cat would've by God laughed.

Big Mama weighs close onto three hundred pounds,

But the Hayesville Beauty Queen didn't sit prouder.

She gave a special wave to the deputy sheriff.

Grinning grinning grinning like she'd stole

The courthouse weathervane. Rocking and grinning and rocking.

"Behind her came the Briar Hill Bluegrass Band

On another wagon pulled by a one-eyed mule.

That's what I thought, the way he drew to the left.

But then he'd pull the other way; and began

To kind of hop and stagger. At last he gave a lurch

And lay down in the traces and went to sleep.

Somebody hollered out, 'That mule's drunk!'

Sure enough he was. Drunk as an owl,

Just from breathing the smoke that was pouring out

From Big Mama's model still. The music stopped.

"Because they'd caught her at last. After all those years ... But what are they going to do? They'd invite her;

They begged her to do her stuff, and so she did. Here came the deputy. 'You're under arrest,' He said-but smiling so the crowd would think It was part of the act. Big Mama's boys stood upWearing phony beards, barefoot with beat-up hats, Just like the hillbillies in the funny papers-

And threw down on the deputy three shotguns.

Whether they were loaded I don't know.

He didn't know. Except Big Mama's bunch

Nobody knew. Fire don't flame as red 
As that man's face. He waved them along, smiling Till his jaw hurt. It'll take a month to relax That smile away. They drove on around the square, Getting their money's worth, leaving behind That passed-out mule for the deputy to have fun with. And went on home, back to the rocks and laurels." "Okay," my father said, "it's good to know The eternal verities still hold their own, That poverty and whiskey and scratch-ankle farming Still prop the mountains up."

"But it ain't that way,"

The old man said. "Big Mama's quit running corn, Except for home use. Ain't no profit in it, With the price of sugar up and the appetite down. Growing these Merry Widow cigarettes, That's where they make their money."

Tradition dying away. The funny papers "Kind of a shame, Will come to be all anybody knows."

"It ain't that bad. I know one high-grade still Still making. If you'd care to have a snort."

"Why not?" my father said. "Time keeps grumbling on. Let's drink us a drink: here at the end of the world." 


\section{Firewater}

1. This is a poem in the storytelling tradition. For what reason, besides entertainment, does the poet tell the story about Big Mama and the mule?

2. What does the father mean when he says, "it's good to know the eternal verities still hold their own?"

3. What kind of changes is Chappell exploring here?

4. What images of Appalachian people are in the "funny papers"? Name and discuss some cartoons, books, and television shows that depict mountain people. 


\section{WILMA DYKEMAN (1920 - ）}

Wilma Dykeman, born in Asheville, North Carolina, is the wife of the late James R. Stokely, Jr., another distinguished Appalachian author included in this anthology. Together they wrote three books, one of which is Neither Black nor White, a winner of the Hillman Award for Best Book of the Year on world peace, race relations, or civil liberties. She has also written two books with her son, Jim Stokely.

A graduate of Northwestern University, Dykeman has been a Guggenheim Scholar and a senior fellow of the National Endowment for the Humanities. Her awards include the Thomas Wolfe Memorial Trophy, the Tennessee Conservation Writer of the Year Award, and a special award from the Chicago Friends of American Writers.

She is a popular lecturer and workshop leader as well as a regular columnist for the Knoxville News-Sentinel. In 1980 she was appointed Tennessee State Historian. Her credits include fifteen books, numerous magazine articles, and book reviews.

The following excerpt from her novel Return the Innocent Earth shows the Clayburn family's commitment to family, God, law, and money. 


\section{From Return the Innocent Earth}

The Clayburns believed.

They believed in the brick house. Home, foursquare against the storms that swept down from the mountains in summer, high and cool under the slow lingering burn of summer sun. Secured by deeds and taxes, paint and repairs and sweat. Durable, permanent brick.

They believed in the white clapboard church. It sat on a hill flanked by a cemetery on one side and a grove of poplars on the other. In the cemetery time vanished. Tall, imposing shafts of chiseled granite coexisted with crumbling homemade headstones. Shallow letters gradually eroded under rain and freeze and thaw and a green beard of moss. The stones recorded death and spoke of life: "She Is Gone But Not Forgotten." "We Shall Meet On That Beautiful Shore." For all their certainty of heaven and simplicity of statement they revealed anxious fears and sorrows. In the tangled weeds and vines around the stones small chipmunks hid and insects ticked noisily on autumn afternoons.

They believed in the concrete courthouse. At Churchill's core, it filled a ragged square of trampled grass. Its windows were blinded by years' accumulation of dust and grime and smoke. Inside, the rooms were saturated with stale smells of human bodies and old paper. On the once-varnished shelves rested documents of boundaries, ownership, wedlock, inheritance, as well as murder, theft, and countless variations of petty and monumental evil brought to judgment. The records, written in long hard-backed ledgers, accumulated in piles as thick as layers of sediment built up during the slow geologic passage of time. Their glossy red spines, faded to match the number of years they had lodged there, indicated the era of each legal stratum. On the second floor stood the judge's bench and jury's box and public seats and spittoons of the county courtroom. On the top floor rested the county jail. The bars across its windows gave the building a top-heavy appearance of grandeur masked, of majesty hoodwinked. 
They believed in the rock-veneered bank. Solidly it fronted on Churchill's fickle main street which alternated between such extremes as a suck of mud or a wallow of dust. The bank's doors opened and shut more regularly than clockwork. The men in high collars who sat behind its desks and stood behind its counter-windows appeared as imperturbable as the fixed countenances of G. Washington and A. Hamilton on the paper they handled each day.

These were the boundaries of Clayburn belief, translated into wood and solidified into mortar. Family. God. Law. Money. And these translated into the big slippery words: love, purpose, order, security.

I try to understand how the rightness of their faith was also error, why it did not create for my children Lee and Ellie a world less destructive and corrupt. Was their vision as limited as mine is? Family as refuge. God as scorekeeper. Law as vengeance. Money as life.

They believed in the words and in the institutions. And from that belief they drew strength. I grew up surrounded by this strength. It was as familiar as the drone of my family's voice in the yard on a summer evening, as unselfconscious as my Aunt Nettie Sue's anthems at Easter and Christmas, as unquestioned as the slightly tarnished badges of the county sheriff, as tangible as safety deposit vaults. I could receive the strength, but it was not my father's strength because I could not also receive his belief. That is an anchor each one puts down for himself.

Is there anyone who grew up in the mountains, the South, America, as I knew them, who did not experience a crisis of belief? Perhaps so. It is not easy to question in the midst of total acceptance. It is not easy to strike through the thorn bushes when the highway has been cleared and smoothed by so many ahead.

By the time I was growing up, the Clayburns no longer lived on the farm, no longer attended the little white church. They had moved into Churchill and its First Baptist Church. (Many of the factory workers attended the Second Baptist, a 
frame structure on the opposite side of town. At the Open Door Baptist Church, in what was called Jaybird, Delia and most of the black population of Churchill worshiped. As for the farm hands, they erected a Clayburn Primitive Baptist Chapel on Grindstone Creek, six miles from town, where they shouted and washed each other's feet and "came to glory." Farther away, near the head of the creek, nestled the one-room Grindstone Hard Shell Baptist Tabernacle, where during long summer services certain mountain men and women handled copperheads and rattlesnakes to prove their trust in all-watchful Heavenly Father.) The Clayburns had joined with the Montgomerys in enlarging the First Baptist building and giving it the permanence of brick. (The Clayburns set great store by brick-neat and orderly, without the unexpected shapes and jagged edges of stone or the weathering and decay of wood.) It was there I heard my first Bach, disguised as a hymn, and my first poetry, disguised as Solomon's description of the church as a bride. Church defined the boundaries of our lives: culture and entertainment and therapy as well as religion.

Above all, reality of the world's evil and possibility of heaven's existence were etched deep in my consciousness there. Week after week the stylus moved, biting deeper, whether or not I listened, whether or not I accepted, simply repeating until it buried the message within me.

How could I ever have told Teena, with her cool Episcopalianism, her midwestern practicality, what it was like to be a small boy on Sunday morning in Churchill? How can I ever convey it to Deborah, with her experience of the disciplined intellect and the raw horror? Yet if they do not understand this, they know nothing.

(Teena said to me, just after Lee was born, when I was ready to leave Clayburn-Durant-then talked with Aunt Lottie and considered the responsibility of having a son and being a sonand stayed: "You Southern boys really are tied up in knots, aren't you?" Teena smiled so that her words did not bite but merely stung. "Carrying that burden of family and salvation 
and God knows what else around with you, like a tortoise with its precious shell-")

Sunday morning was Puritan in its outer sternness and pagan in the abundance of its inner physical sensations: the smell of starch and toilet water and oiled benches and fraying hymnals, the throb of an organ swelling off-key on the bass notes, the radiant mystery of stained glass, the whisper and tinkle of the collection plates' passage through the congregation.

Above all, Sunday morning was the music-sad, sentimental, militant, tightening your throat and chest for all the loss or glory of the world - and it was the minister's voice, angry or pleading, moving or awesome, cultivated or half-wild, but onto something no one present could dismiss or disprove. We might dislike, but we could not escape. Sunday was a day to ponder on our immortal souls and feast on fried chicken.

"Blessed assurance, Jesus is mine, oh what a foretaste of glory divine...."

Afterward the melting delicacy of golden corn pudding.

"Onward Christian soldiers, marching as to war...."

The sweet rise and fall of the rhythm, the pulse-pounding beat of the march, the primitive blood and beauty, the sincere, solemn faces upturned briefly with all the hint of rapture they would ever know: such memory-even in the boiler-room pressure of today, even in this world which seems as far removed as the Pre-Cambrian age or the time of the great fern forests-mellows my attitudes, touches me to unaccustomed pity for those who could believe so faithfully, as well as for those who cannot believe at all.

There was another dimension to the belief. Revivals came in mid-summer during seasons of parching drought or drenching flood, when the land, like the people, lay ready for either renewal or rescue. Again, in my present world of young George Hodges and instant answers from the machine, of knowledgeable Bonita Fredericks and stylish conformities, of inter-office memos and board meetings and daily decisions for sixty-four plants and people ranging from Madison Avenue 
admen selling Clayburn-Durant's image on t.v. screens to Mexican wetbacks in the Rio Grande valley harvesting fruit for our cans-in this world the residue of long-ago revivals seems thoroughly submerged.

\section{And yet-}

One of those summer meetings brought my first personal knowledge of my cousin Stull.

In mid-August that year the brown canvas tent spread wide like a shallow, muddy pool in one of Alexander Montgomery's empty fields at the edge of Churchill. Pungent odor of the canvas mingled with the smell of fresh pine lumber from one of Colonel Wakely's sawmills that was used to build row after row of benches. Around the outer edges of the tent, dry stalks of weeds and Queen Anne's lace and fading purple thistles persisted like a stubble of beard. On the bare plank platform in front of the banked seats stood a small home organ and a lectern. This established the domain of Kincaid and Truesdale, musician and evangelist of "world-wide fame."

For two weeks in the August heat they sang and shouted and exhorted and pleaded and it seemed to me that the town and everyone I knew was forever changed. Great-uncle Whit Ransom, tears streaming down his florid face, took an oath to give up strong drink for the rest of his natural life. Old Sledge Hartwick, overcome by the spirit, vowed to the singing, watchful congregation that no matter how hot his blacksmith's shop became or how heavy the hammer he would never use curse words again, be damned if he would.

Memphis Gibson and two of her girls cried at the mourner's bench and promised repentance of their carnal ways. (I overheard Uncle Cal tell some men the following day that he bet there were a raft of good male citizens hated to hear that promise made, even for a little while. I wondered what he meant.) And cautious Alexander Montgomery wrote a check for one thousand dollars to launch the final love-offering for Brother Truesdale.

Of all the moments or events which startled and stirred us during those emotion-laden days, however, none equaled for 
me the sight of my cousin Stull Clayburn walking to the front, grasping the outstretched hand of Mooney C. Truesdale, committing his life to God and accepting the Holy Spirit.

That night at home in bed I tried to remember what the Reverend Truesdale had said. Random sentences lodged in my mind like driftwood scattered from the waves of warning, threat, and strange angry love that had washed over the congregation before him.

Oh, let the wind blow, brother. Let the wind howl and the rivers rise and a flood of lamb-purified blood descend into our withered church-baked hearts....

Some say: Brother Truesdale, I've got my own religion. Yes, my brother, but do you have God's religion? Folks don't like to hear the truth about their corruption and their devilment. But I'm not preaching folks' way. I'm preaching the Lord's way. God be praised! That's the rocky trail I've follered since that day I was ploughing in the hillside fields and the Lord called on me to lay down the plough handles and take up the sword for Him. "Lord," I said, "I may be a poor old worthless varmint, but if you're a-wanting me I'm all yours, bone and shank and head and hand," and that's the way it's been and the Lord has blessed me beyond all deserving.

Oh, you say, Brother Truesdale, I don't have time to work for the Lord God Almighty. I've got to run my store and see after my mill. I've got to tend my tobacco fields and feed my white-face heifers. Oh dear brother, the mercy of the Lord God be upon you. God hates a proud look. God hates an owner's grasp. You're just a steward and tender of His earth. And if you can't humble yourself you' re headed for brimstone where the fire is never quenched and the worm is never fed.

Your time here is short as a borrower's memory, no matter how young you be. The days of the little babe at its mother's teat are brief as candles. Too soon the hour of wrath will come upon us like a rending storm. That's why I'm a-pleading with you now, this breath; accept the Lord; be baptized in the flow.

I want to see an old-time sin-killing Holy-Ghost revival. I 
came here on fire with the Lord and I'm not a cinder yet. We'll burn out the proud flesh in our secret hearts.

Let the agnostics and the atheists, the haughty doubters, have their little day on earth. The gathering of the believers and the faithful, the saved and the chosen, will be in heaven. It will come for eternity. It's the gift of God; you have only to reach out with your own pitiful little mortal hand and accepttonight, now, this minute.

You may never live to return back to this old tent tomorrow night. You're making your eternal choice-for heaven or hell. Don't $O$, brother or sister, don't disinherit yourself forever from the love of God.

I did not want hell.

Was I a haughty doubter? I did not mean to be.

I wanted love. I wanted to be the faithful and the chosen. I wanted eternity. And heaven.

Yet I sat on the plank bench with my feet anchored in sawdust and I could not move.

Then I saw Stull. Stull walking down the aisle, a serious young man (and I still a child), wearing a watch fob like my father. He was sweating lightly so that his face and forehead shone in the flickering light. His shoes squeaked slightly with every other step but no one heard or paid attention in the midst of the rapturous singing.

There is a fountain filled with blood

Drawn from Emmanuel's veins,

And sinners plunged beneath that flood

Lose all their guilty stains....

Lose all their guilty stains....

The vision of a fountain flowing with the warm sticky scarlet of fresh blood made me shudder.

Stull looked straight ahead. The congregation stirred as everyone craned to see him. All of the adult Clayburns and most of the children above infancy, including my brother 
Monty, had professed faith and joined the church long since. At that moment, only Stull and I did not belong, only we had not washed away our guilty stains, and it appeared that very soon I would be the only one left in that wretched condition.

Stull's father and mother sat on the seats just in front of ours, and when my mother leaned forward and patted them on the shoulder they turned to smile radiantly. I saw tears glistening in Aunt Nora's eyes. If my mother had been crying I would not have been surprised, for she laughed and cried easily. Aunt Nora, however, was another matter. She did not yield often to any display of her inner feelings. Her tears, brimming like iridescent bubbles ready to break, confirmed for me the solemnity and importance of the moment.

I looked back at Stull. Preacher Truesdale had stepped down from the platform onto the grass and sawdust, laid a long shirt-sleeved arm around Stull's shoulders. He held up his other hand for a pause in the music. His shirt was wet, sticking to his skin, outlining the undershirt he wore.

His voice was hoarse and triumphant. "Our fine young brother Stull Clayburn comes to God tonight. Let us all rejoice. $\mathrm{Oh}$, there will be gladness among the angels in heaven this night."

I could feel the surrounding waves of emotion rolling over me. I tried to see Stull again but he was kneeling now. Suddenly I felt my mother's hand in mine and a strong squeeze. I looked up into her face. She was gazing at me with a question. A hope. And a longing. My chest tightened with love for her.

But I could not go down the aisle. I could not join.

On the way home my mother spoke to my father but I knew she was addressing me. "Little old Stull! I know how Nora and Josh must feel tonight to know that he's accepted the Lord."

There was a short silence. My father spoke quietly, almost to himself. "Stull has a good head on his shoulders. He's a smart boy."

"That shows you," Mama nodded, "no one is smart enough not to need the Lord's saving grace."

"Why don't you get saved, Jon?" Monty piped up from the 
seat beside me. He had been a loyal Baptist for two years already.

"Don't push Jon, Monty," Mama said. "He'll know when he's ready. The Lord works in mysterious ways-" She reached back and patted me on the knee. But I knew she was glad that Monty had asked, had reminded me, had prodded.

Alone in bed with my guilt that night I wondered about the awesome experience all of those around me had had, which I had not yet known.

"There is a fountain filled with blood...."

The sound of old Number Seven, the midnight train from Chicago to Charleston, came up to me from the tracks through Churchill at the bottom of our hill. The engineer played a long tattoo with his whistle. Mike $\mathrm{O}^{\prime}$ Leary! He was famous from the Great Lakes to the Atlantic seaboard for his spit-and-polish engine, gleaming black with bright brass bell and hand-holds, and the voice he gave to that resonant whistle.

"Whoo-oo-oo, whoo-oo-oo-oo, who...."

The clear lingering call, with each note falling pure and separate as drops of rain, seemed a cry of such distilled loneliness, echoing from the valley into the hills, that it brought me a sad, self-conscious comfort.

The next day I could hardly wait to see Stull.

My father had put Monty and me to work for the last two summers in the Riverbend Farm fields picking tomatoes. I was eight years old and Monty was ten and all the men told us that since we didn't have so far to stoop our backs didn't ache the same way theirs did from the picking. Maybe not. But during the first days each season I didn't see how anyone's back could ache more than mine. But then I learned how to give to the bends, how to rest on one knee at an especially heavy vine. The ground yielded hot and soft under our bare feet.

At noon Stull brought a fresh supply of water for the pickers.

As he drew up at the end of the field under the shallow shade of a row of sycamore trees that grew along the riverbank, Ileft my row without waiting for anyone to tell me to help with 
the water-kegs and ran toward Stull. In his work clothes, squinting against the midday glare, he didn't appear much different from the way he had every other morning that summer.

"I hope you get these kegs unloaded as quick as you can," he was saying to old Orvil Gosnell, the field foreman, as I came up panting and breathless. "I've got to get home to dinner so I can take Uncle Jonathan to Jackson City this afternoon."

I could tell by the way Orvil Gosnell spat a wad of tobacco juice into the bushes that he didn't like the way Stull spoke. He banged the kegs onto the ground.

"Stull, I want to ride back with you," I blurted out. The idea had just come to me. "I've got to go home. I'm feeling sick to my stomach."

My cousin looked at me. The expression on his face did not change a fraction.

I turned to Orvil Gosnell. "My mother would want me to come home. She always worries the worst way if our stomachs are upset."

"That's true," the old man spat again, remembering I suppose all the paraphernalia of separate water jugs and dippers and straw sunhats that my brother and I had brought to the fields. "You go on home."

As Stull and I bounced away, I looked over at him. He did not speak. For all I could tell, the miracle of the night before at the Kincaid-Truesdale meeting might never occurred.

"I was at the revival last night," I said.

He did not look around. "That man can really talk."

I clutched at the door handle. It was hot from sitting in the sun and I let loose quickly. "But you were saved," I said.

"That's right."

When he did not go on I tried to. "You professed your sins and your faith and you accepted the Lord Jesus Christ."

He was looking at me now-back at the road and then at me.

Was I breaking some unwritten code, committing some unforgivable breach? Was Stull's testimony, his act of faith, beyond all explanation or statement or discussion? But the 
guilt throbbing through those hymns, the loneliness wailing through Number Seven's whistle, remained inside me from the night before, and I had to try to know; I had to know.

"Stull," I swallowed dry spit and began again. "Stull, how does it feel?"

His gray-blue eyes-the no-color of the hazy summer sky-stared at me. "How does what feel?"

"The change. The change inside you. Knowing that you've accepted God's love, and eternity and heaven-"

"You trying to make fun of me?" He was scowling.

I could feel the blood flushing my neck and face.

"Oh no, Stull. I just want to know how it is to believe-"

He stopped scowling. I saw that he was convinced of my sincerity and, simultaneously, of my stupidity. I grew even redder. I wanted to stay silent but I went on talking. "You and I were the only ones in the family who hadn't made professions. I would-if I could," I went ahead lamely.

The car hit a ragged chughole and we bounced on the hard narrow seats. Stull put in the clutch and shifted to second gear.

"That's what I wanted to ask you about this morning," I made a last weak effort, "how it is -"

"How what is?"

I did not know what else to say.

We turned from the farm road onto the county highway. I had begun to suspect that there were no chariots of glory to envelop our spirits, only cars that rattled on errands for our business.

"Mama and Daddy, they'd like it if I went down to Preacher Truesdale, too-"

This time he answered me. "Why don't you go then?" ment.

"I don't know." And that was a completely honest state-

"It's the smartest thing," Stull said.

Ilooked out of the window at the dusty road straight ahead.

"You know you believe in God," he went on more easily. "After all, even if He isn't there it hasn't done any harm."

I nodded. But I was not satisfied. 
"So I say, might as well join on up. The church can do good for you, too." He winked at me in a camaraderie we had never shared before. We did not share it now.

I sat huddled on the seat with my hands beneath my legs, legs weak as if from a long sickness. We were nearly home. At our driveway Stull paused and I crawled out of the car. Before he continued on to the adjoining driveway, his own, he leaned out the window and said, "Don't think so much, kid. Go on and join. It'll make you feel better. I'm glad I did." He didn't often say "kid," a holdover from his college past. Any other time but this I would have been flattered to have him address me so.

When I told my mother I had come home from the tomato fields because of an upset stomach, it was no longer a total untruth. Everything seemed upset at that moment. My mother's reaction to any suggestion of sickness satisfied the sufferer totally. Her concern sufficed for the situation and made it easy for everyone else to take a calm and reassuring outlook. My mother's personal catalogue of illnesses permitted no minor ailments. A runny nose heralded pneumonia; a single pain in the region of the abdomen became a symptom of appendicitis.

Of my stomach disorder she gasped, "It's the season forfor typhoid!" And her blue eyes widened in alarm as she telephoned my father at his office. After talking with him she grew calmer. She brought me baking soda in a glass of water and put me to bed.

It felt strange to be in bed at midday. My mother had drawn the shades against the noonday light and the room took on a golden cavelike glow. From a sewing nook down the hall came the clean smell of fresh smooth cloth. I knew that Serena's daughter was ironing there. The familiar thought and smell comforted me.

But I knew the code I had broken with Stull. Even then I knew, although I could not have put it into words. We (especially we boys, we men) were not supposed to discuss the innerness of life. We were supposed to observe true division of Sunday from Monday. We were splintered into a half-dozen 
fragments and our maturity was measured not by trying to make the parts into a whole but by juggling the pieces cleverly, separately, so that no one saw the empty spaces.

That night, the last night of the great revival, I stayed at home. My mother brought me salted chicken broth in one of her white Haviland consommé cups. The gold band around its edge gave the broth a slightly metallic flavor as I sipped. I swallowed its delicacy slowly. It reminded me of times when my stomach really had been churning and this salty golden juice had soothed and nourished me back to normal. Remembering made me sad, made me feel older in a way that I did not want to feel.

From that August day forward I never discussed any but matters temporal with Stull. And I remained acutely aware of the embarrassment most Clayburns felt in confronting or discussing the creative, spiritual, moral, sexual, intangible forces of their lives.

Yet those older ones-my grandmother, my father, my uncles-believed. And who am I to judge their belief? Shall I judge them against their descendants, against my friends, against all those lukewarm bodies who do not believe or disbelieve-who have only arrangements, conveniences, patchworks for their lives?

When Teena died there were letters, condolences, murmured conversations. Those who knew us assumed that this would be my trough of the wave, my time for asking why and who and seeking some reconciliation between the master plan and the daily drone. Lee and Ellie had their questions, too. But I was arrogant, maybe even apathetic, not to say that they were really my questions, also.

It was not Teena's death but Deborah's life that led me to think less about Clayburn-Durant problems and more about belief.

There is power, power, wonder-working power In the precious blood of the Lamb. 
416 The Change Hits Home

Was the blood that drenched Deborah's life precious? My memories and questions weave into nets. At this moment I find less need to understand my cousin Stull's power than to appreciate my father Jonathan's strength.

\section{Return the Innocent Earth}

1. Jon, the speaker in this selection, says that the Clayburns believed in Family, God, Law, and Money. What concrete examples are given which more specifically illustrate these words?

2. What sensations does Jon associate with Sunday morning?

3. Discuss Jon's inner conflicts with regard to religion.

4. What lesson does Jon learn from his cousin Stull? 
Illustration No. 8

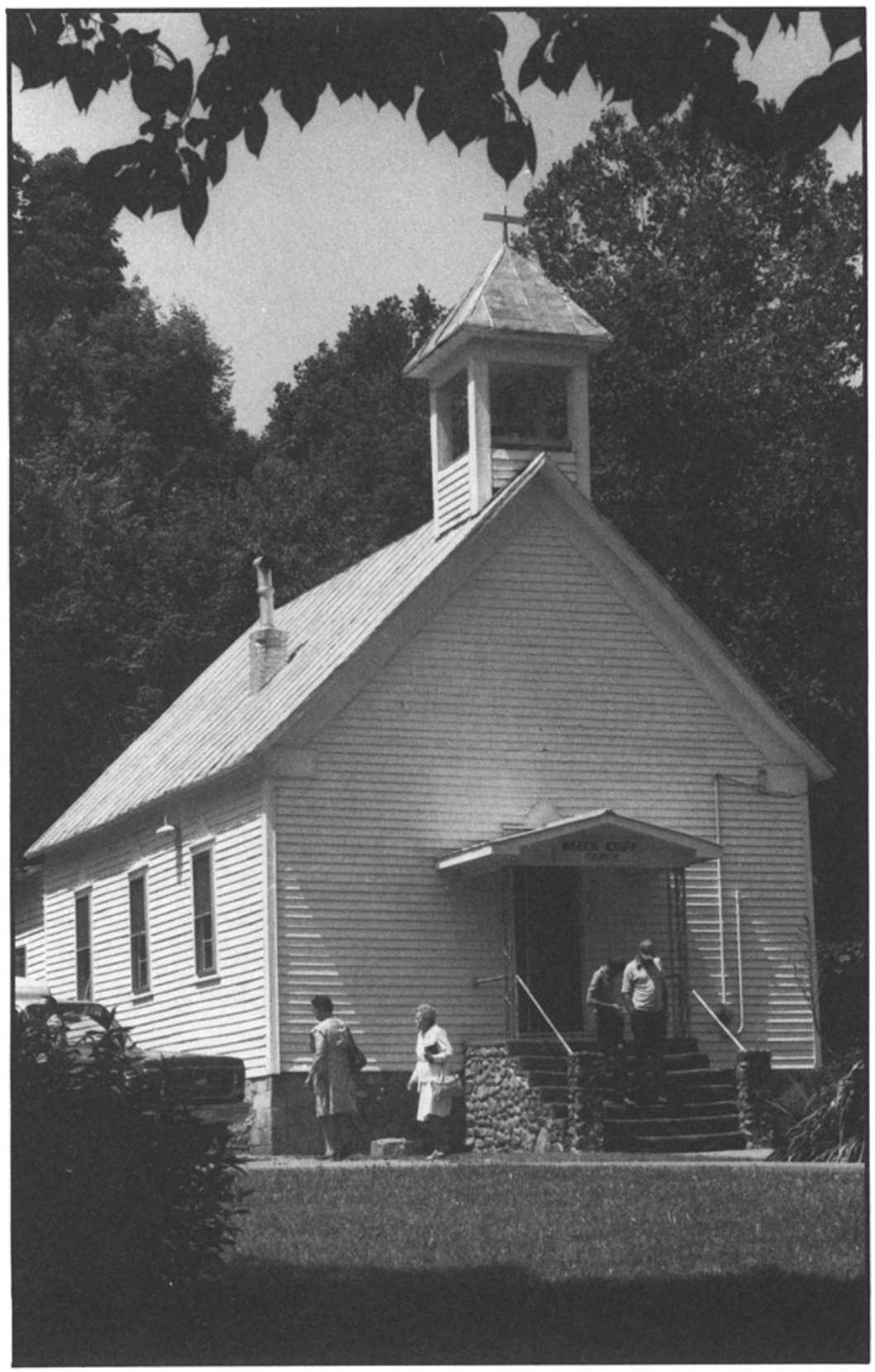


JIM WAYNE MILLER (1936 - )

A native of western North Carolina, Jim Wayne Miller earned his undergraduate degree at Berea College in Kentucky. Hecontinued his studies at Vanderbilt University and received his Ph.D. in both German and American literature in 1965. While at Vanderbilt, Miller studied under Fugitive poet Donald Davidson.

At present, Dr. Miller is a professor of German language and literature at Western Kentucky University. His stature and reputation as a poet have grown steadily since his first volume of poetry, Copperhead Cane, was published in 1964. His other collections are Dialogue With A Dead Man, The Mountains Have Come Closer (for which he received the Thomas Wolfe Literary Award in 1985), Vein of Words, and Nostalgia for 70.

"The Brier Losing Touch With His Traditions" is about a craftsman who tries to please the public by being authentic. But he also pleases himself by being himself.

\section{The Brier Losing Touch With His Traditions}

Once he was a chairmaker.

People up north discovered him.

They said he was "an authentic mountain craftsman." 
People came and made pictures of him working, wrote him up in the newspapers.

He got famous.

Got a lot of orders for his chairs.

When he moved up to Cincinnati so he could be closer to his market (besides, a lot of his people lived there now) he found out he was a Brier.

And when his customers found out he was using an electric lathe and power drill just to keep up with all the orders, they said he was losing touch with his traditions. His orders fell off something awful. He figured it had been a bad mistake to let the magazine people take those pictures of him with his power tools, clean-shaven, wearing a flowered sport shirt and drip-dry pants.

So he moved back down to east Kentucky. Had himself a brochure printed up with a picture of him using his hand lathe, bearded, barefoot, in faded overalls.

Then when folks would come from the magazines, he'd get rid of them before suppertime so he could put on his shoes, his flowered sport shirt and double-knit pants, and open a can of beer and watch the six-thirty news on tv out of New York and Washington.

He had to have some time to be himself. 
The Brier Losing Touch With His Traditions

1. What does the term "authentic mountain craftsman" suggest in this poem?

2. Discuss the irony in the chairmaker's attempt to please his customers.

3. Has the Brier lost touch with his traditions, as the title implies? 


\section{KATHRYN STRIPLING BYER (1944 - ）}

Kathryn Stripling Byer of Cullowhee, North Carolina, received her Master of Fine Arts degree from the University of North Carolina at Greensboro where she studied with Fred Chappell. Her poems have appeared in numerous magazines, journals, and anthologies. Her first book of poetry, The Girl In the Midst of the Harvest, which opens with the poem reprinted here, was published by Texas Tech Press as part of the Associated Writing Programs competition.

Among Byer's honors are the Academy of American Poets Prize in 1968, the Anne Sexton Poetry Prize for 1978, and a North Carolina Artist's Fellowship for 1986.

\section{Wide Open, These Gates}

Going down the road feeling good, I snap my fingers. Hear, Hear! At an auction my father bid sixty-five dollars for a fat Hampshire pig just by rubbing his nose. When my grandfather scattered his seed to the four corners, corn stood up tall as his hat brim. My grandmother's sheets flapped like bells on the line. Crabbed youth, crab apple, crepe myrtle, I mumble 
as I shuffle downhill, my crabbed youth behind me like gnats singing. I've come a long way from what's been described as a mean and starved corner of backwoods America. That has a ring to it. Rhythm, like my grandmother's hands in the bread dough. Her food made the boards creak, my grandfather mellow. He had a wild temper when he was a young man. Most folks talk too much, he'd say, aiming slow spit at a dung beetle.

He never mumbled. Sometimes he talked nonsense

to roosters and fierce setting hens. My nonsense coos

like a dove. Goodbye swallowtails cruising the pigpen. Goodbye apple dumplings. Goodbye little turkeys my grandmother fed with her fingers.

Big Belle was a nanny goat. Holler "Halloo"

after sundown and all the cows come home. Some words are gates swinging wide open, and I walk on through one more summer that like this road's going down easy. The gnats sing, and I'm going to sing. One of these days I'll be gone.

\section{Wide Open, These Gates}

1. Characterize the grandmother and grandfather in the poem. Although there is little real information, how do you imagine them?

2. The first line is a play on a song title "Goin' down that road feelin' bad." Find words and images that have to do with singing and music.

3. The last stanza has several goodbyes in it. To what is the poet really saying farewell? Does she seem sad about it?

4. Why do you think the poet chose to begin a collection with this poem? 


\section{COMPOSITION TOPICS}

1. Compare/contrast city life and country life.

2. Write a narrative about someone you know who has gone far away to work or to go to school. Describe their experience-their feelings, problems, what they learned.

3. Write an essay about your dreams and plans.

\section{ACTIVITIES}

The chapter you now add to your book will tell more about your family. Families frequently have heirlooms, prized possessions which they pass on from one generation to the next. An heirloom may be a watch, a gun, furniture, or the old iron skillet your grandmother used. Write about two of these heirlooms. Give the history and description of each and include photographs or drawings.

Families also have important documents such as land grants, wills, and marriage licenses. Photocopy a family document to include in this chapter of your family scrapbook. 
This page intentionally left blank 


\section{CHAPTER 7 \\ Appalachian Emigration: \\ Looking for Work, \\ Longing for Home}

During and after World War II there was a tremendous exodus from the Appalachian region to the industrial centers of the North. Significant numbers of mountain people moved to such cities as Dayton, Ohio; Chicago, Illinois; and Detroit, Michigan. They left looking for work and a better life.

At that time the Appalachian region could offer only lowpaying jobs in coal mining, lumbering, or farming. The factories of the North promised good money, better schools, and excitement. Still, many were disappointed with life far away from friends and family. They found themselves in a strange world, sometimes even cruel, where people made fun of their ways and their talk. People in these cities labeled them as "Briers," "Sams" (Southern Appalachian Mountaineers), and "Hillbillies."

Harriette Arnow's novel The Dollmaker, which has been 
made into a television movie starring Jane Fonda, is the most famous treatment of Appalachian emigration. As the central character Gertie Nevels moves from the mountains to the industrial North and struggles to achieve her place there, she symbolizes the pioneer spirit of former times. Yet Gertie, in spite of her will to survive, becomes a victim. She is caught up in a force over which she has no control: the lure of industry. As a resident of a housing slum in Detroit, she becomes a displaced person in a foreign land where she dreams of her Kentucky hills.

In the 1960s when more opportunities opened up in Appalachia and the population in the mountains began to grow, this emigration began reversing. New highways, water systems, and industrial parks had opened the region to more businesses. Manufacturers and retailers gave people more diversified opportunities to live and work in the area.

There is another, more compelling reason for the reversal in this trend. People in Appalachia have always felt a strong tie to their families. They want the whole clan in one place. They also feel a strong attachment to the land. The selections in Chapter 7 are about leaving and coming home. The pull of kinship and the longing for mountain sights are powerful motifs for these writers. 


\section{ROBERT MORGAN (1944- ）}

Robert Morgan was born in Henderson, North Carolina, and grew up near Zirconia on a farm which had been in his family since 1840 .

After studying science and math at the University of North Carolina at Chapel Hill, he switched to English and graduated with honors in writing. While working on his MFA at UNCGreensboro, he was influenced by Fred Chappell, who is also included in this anthology.

Since 1965 he has published over three hundred poems in journals and popular magazines. In addition, he has published six collections of poetry-Zirconia Poems, The Voice in the Crosshairs, Red Owl, Land Diving, Groundwork, and Trunk $\mathcal{E}$ Thicket. The National Endowment for the Arts has awarded him two fellowships.

Although Robert Morgan has taught creative writing at Salem College and is now at Cornell University, he has also painted houses and worked at odd jobs to support his family.

This poem concerns a boy's dream of leaving the hard life of the farm to find an easier one. 


\section{Bean Money}

Back from the market late with a watermelon and his bib-pocket full of cash my father shoved a fist of back-pay for the summer at me, the yield from digging holes and tying strings, lugging hampers in the rain with heat rash, stings and blisters. In my room I'd sit with dirty feet and sweat-ripe skin on the sheets and unwad the damp bills to press in stacks like pages of a ledger of the hot days, the green and gray ink more lasting than sunburn or calluses, and telling of my labor with a one-eye lit pyramid. I collated and banded the leaves in bundles and counted out the coins like next year's seeds into the old tobacco pouch. That consecrated metal was an abstract drawn off the soil and sweat and cast into a jewelry of value.

I meant those struck emblems to act as compact fuel, like nuclear pellets, to power my long excursion out of the sun and beyond the ridges, and put them all in a paper box above the closet door to trade later; the young summers become signs to be translated again into paper, ink and paper, in the cool timeless leisure I saw while washing my feet on the back steps and spitting melon seeds into the cricket-haunted dark. 


\section{Bean Money}

1. Why does the boy consider his summer wages "consecrated metal" that are "cast into a jewelry of value"?

2. What does the boy plan to do with his money?

3. What valuable lessons can a young person learn from earning and saving his own money? 


\section{Illustration No. 9}

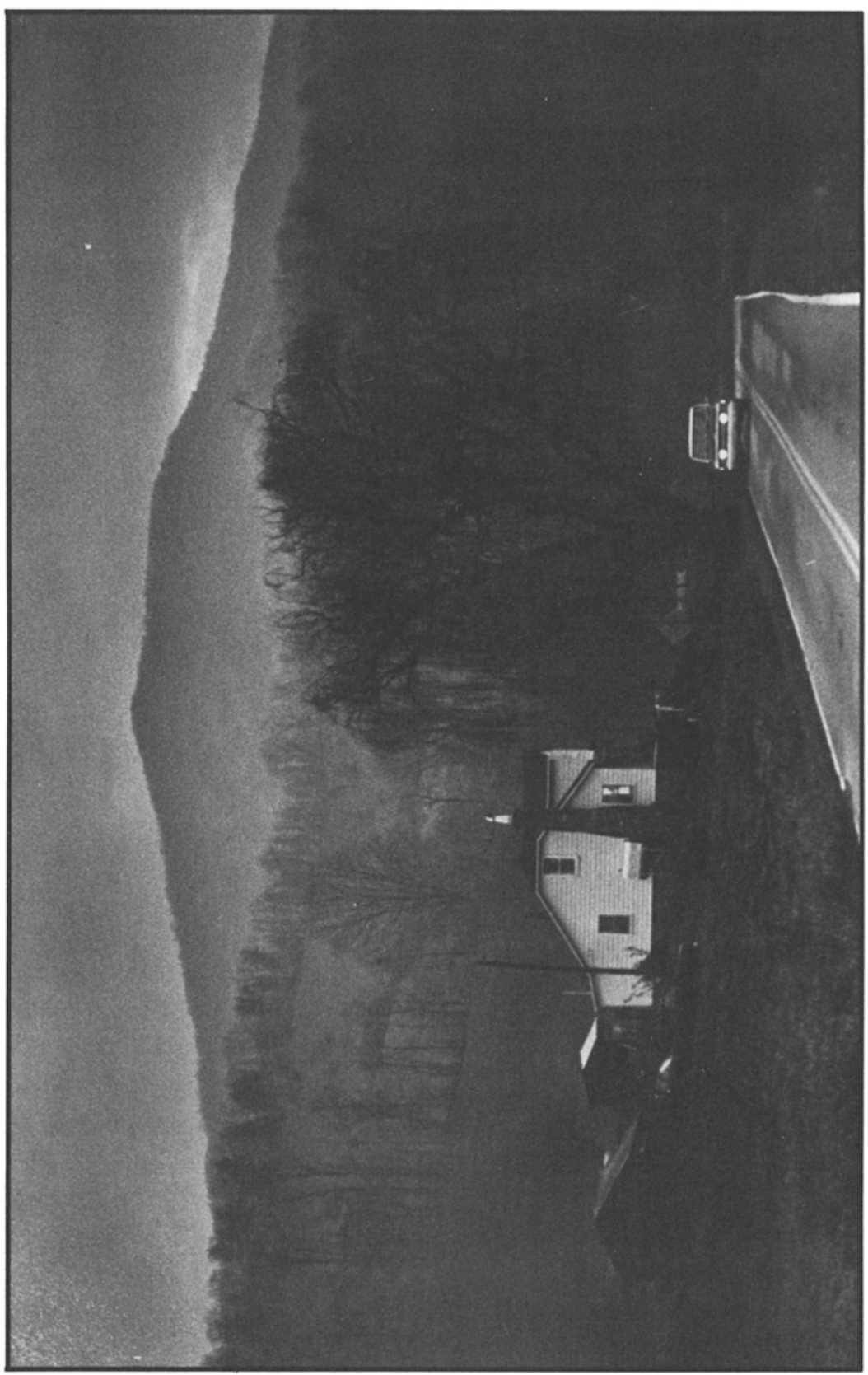




\section{BOBBIE ANN MASON (1941 - )}

Bobbie Ann Mason, who grew up near Paducah, Kentucky, writes about characters and settings that are no longer rural yet are not suburban. She captures transition, both the old and new mingling.

She is the author of Nabokov's Garden, The Girl Sleuth, and Shiloh, a collection of short stories.

This story, first published in The New Yorker before being included in Shiloh, depicts Nancy Cleveland living the life of a modern, middle-class woman in Philadelphia. She feels a strong identity with the women of her family back home.

Although she leaves her childhood home in Kentucky to go to school and afterwards to live in the Northeast, she returns when her aging Granny must go to a nursing home. Family photographs which tie her to past generations lure her home.

\section{Nancy Culpepper}

When Nancy received her parents' letter saying they were moving her grandmother to a nursing home, she said to her husband, "I really should go help them out. And I've got to save Granny's photographs. They might get lost." Jack did not try to discourage her, and she left for Kentucky soon after the letter came. 
Nancy has been vaguely wanting to move to Kentucky, and she has persuaded Jack to think about relocating his photography business. They live in the country, near a small town an hour's drive from Philadelphia. Their son, Robert, who is eight, has fits when they talk about moving. He does not want to leave his room or his playmates. Once, he asked, "What about our chickens?"

"They have chickens in Kentucky," Nancy explained. "Don't worry. We're not going yet."

Later he asked, "But what about the fish in the pond?"

"I don't know," said Nancy. "I guess we'll have to rent a UHaul."

When Nancy arrives at her parents' farm in western Kentucky, her mother says, "Your daddy and me's both got inner ear and nerves. And we couldn't lift Granny, or anything, if we had to all of a sudden."

"The flu settled in my ears," Daddy says, cocking his head at an angle.

"Mine's still popping," says Mother.

In a few days they plan to move Granny, and they will return to their own house, which they have been renting out. For nine years, they have lived next door, in Granny's house, in order to care for her. There Mother has had to cook on an ancient gas range, with her mother-in-law hovering over her, supervising. Granny used only lye soap on dishes, and it was five years before Nancy's mother defied her and bought some Joy. By then, Granny was confined to her bed, crippled with arthritis. Now she is ninety-three.

"You didn't have to come back," Daddy says to Nancy at the dinner table. "We could manage."

"I want to help you move," Nancy says. "And I want to make sure Granny's pictures don't get lost. Nobody cares about them but me, and I'm afraid someone will throw them away."

Nancy wants to find out if Granny has a picture of a greatgreat-aunt named Nancy Culpepper. No one in the family seems to know anything about her, but Nancy is excited by the 
thought of an ancestor with the same name as hers. Since she found out about her, Nancy has been going by her maiden name, but she has given up trying to explain this to her mother, who persists in addressing letters to "Mr. and Mrs. Jack Cleveland."

"There's some pictures hid behind Granny's closet wall," Daddy tells Nancy. "When we hooked up the coal-oil stove through the fireplace a few years ago, they got walled in."

"That's ridiculous! Why would you do that?"

"They were in the way." He stands up and puts on his cap, preparing to go out to feed his calves.

"Will Granny care if I tear the wall down?" Nancy asks, joking.

Daddy laughs, acting as though he understood, but Nancy knows he is pretending. He seems tired, and his billed cap looks absurdly small perched on his head.

When Nancy and Jack were married, years ago, in Massachusetts, Nancy did not want her parents to come to the wedding. She urged them not to make the long trip. "It's no big deal," she told them on the telephone. "It'll last ten minutes. We're not even going on a honeymoon right away, because we both have exams Monday."

Nancy was in graduate school, and Jack was finishing his B.A. For almost a year they had been renting a large old house on a lake. The house had a field-rock fireplace with a heartshaped stone centered above the mantel. Jack, who was studying design, thought the heart was tasteless, and he covered it with a Peter Max poster.

At the ceremony, Jack's dog, Grover, was present, and instead of organ music, a stereo played Sgt. Pepper's Lonely Hearts Club Band. It was 1967. Nancy was astonished by the minister's white robe and his beard and by the fact that he chain-smoked. The preachers she remembered from childhood would have called him a heathen, she thought. Most of the wedding pictures, taken by a friend of Jack's, turned out to be trick photography - blurred faces and double 
exposures.

The party afterward lasted all night. Jack blew up two hundred balloons and kept the fire going. They drank too much wine-and-7Up punch. Guests went in and out, popping balloons with cigarettes, taking walks by the lake. Everyone was looking for the northern lights, which were supposed to be visible that evening. Holding on to Jack, Nancy searched the murky sky, feeling that the two of them were lone travelers on the edge of some outer-space adventure. At the same time, she kept thinking of her parents at home, probably watching Gunsmoke.

"I saw them once," Jack said. "They were fantastic."

"What was it like?"

"Shower curtains."

"Really? That's amazing."

"Luminescent shower curtains."

"I'm shivering," Nancy said. The sky was blank.

"Let's go in. It's too cloudy anyway. Someday we'll see them. I promise."

Someone had taken down the poster above the fireplace and put up the picture of Sgt. Pepper-the cutout that came with the album. Sgt. Pepper overlooked the room like a stern father.

"What's the matter?" a man asked Nancy. He was Dr. Doyle, her American History 1861-1865 professor. "This is your wedding. Loosen up." He burst a balloon and Nancy jumped.

When someone offered her a joint, she refused, then wondered why. The house was filled with strangers, and the Beatles album played over and over. Jack and Nancy danced, hugging each other in a slow two-step that was all wrong for the music. They drifted past the wedding presents, lined up on a table Jack had fashioned from a door-hand-dipped candles, a silver roach clip, Joy of Cooking, signed pottery in nonfunctional shapes. Nancy wondered what her parents had eaten for supper. Possibly fried steak, two kinds of peas, biscuits, blackberry pie. The music shifted and the songs merged 
together; Jack and Nancy kept dancing.

"There aren't any stopping places," Nancy said. She was crying. "Songs used to have stopping places in between."

"Let's just keep on dancing," Jack said.

Nancy was thinking of the blackberry bushes at the farm in Kentucky, which spread so wildly they had to be burned down every few years. They grew on the banks of the creek, which in summer shrank to still, small occasional pools. After a while Nancy realized that Jack was talking to her. He was explaining how he could predict exactly when the last, dying chord on the album was about to end.

"Listen," he said. "There. Right there."

Nancy's parents had met Jack a few months before the wedding, during spring break, when Jack and Nancy stopped in Kentucky on their way to Denver to see an old friend of Jack's. The visit involved some elaborate lies about their sleeping arrangements on the trip.

At the supper table, Mother and Daddy passed bowls of food self-consciously. The table was set with some napkins left over from Christmas. The vegetables were soaked in bacon grease, and Jack took small helpings. Nancy sat rigidly, watching every movement, like a cat stationed near a bird feeder. Mother had gathered poke, because it was spring, and she said to Jack, "I bet you don't eat poke salet up there."

"It's weeds," said Nancy.

"I've never heard of it," Jack said. He hesitated, then took a small serving.

"It's poison if it gets too big," Daddy said. He turned to Nancy's mother. "I think you picked this too big. You're going to poison us all."

"He's teasing," Nancy said.

"The berries is what's poison," said Mother, laughing. "Wouldn't that be something? They'll say up there I tried to poison your boyfriend the minute I met him!"

Everyone laughed. Jack's face was red. He was wearing an embroidered shirt. Nancy watched him trim the fat from 
his ham as precisely as if he were using an X-Acto knife on mat board.

"How's Granny?" Nancy asked. Her grandmother was then living alone in her own house.

"Tolerable well," said Daddy. her."

"We'll go to see her," Jack said. "Nancy told me all about

"She cooks her egg in her oats to keep from washing an extry dish," Mother said.

Nancy played with her food. She was looking at the pink dining room wall and the plastic flowers in the window. On the afternoon Jack and Nancy first met, he took her to a junk shop, where he bought a stained-glass window for his bathroom. Nancy would never have thought of going to a junk shop. It would not have occurred to her to put a stained-glass window in a bathroom.

"What do you aim to be when you graduate?" Daddy asked Jack abruptly, staring at him. Jack's hair looked oddly like an Irish setter's ears, Nancy thought suddenly.

"Won't you have to go in the army?" Mother asked.

"I'll apply for an assistantship if my grades are good enough," Jack said. "Anything to avoid the draft."

Nancy's father was leaning into his plate, as though he were concentrating deeply on each bite.

He makes good grades," Nancy said.

"Nancy always made all A's," Daddy said to Jack.

"We gave her a dollar for ever' one," said Mother. "She kept us broke."

"In graduate school they don't give A's," said Nancy. "They just give S's and U's."

Jack wadded up his napkin. Then Mother served fried pies with white sauce. "Nancy always loved these better than anything," she said.

After supper, Nancy showed Jack the farm. As they walked through the fields, Nancy felt that he was seeing peaceful landscapes-arrangements of picturesque cows, an old red barn. She had never thought of the place this way before; it 
reminded her of prints in a dime store.

While her mother washes the dishes, Nancy takes Granny's dinner to her, and sits in a rocking chair while Granny eats in bed. The food is on an old TV-dinner tray. The compartments hold chicken and dressing, mashed potatoes, field peas, green beans, and vinegar slaw. The servings are tiny-six green beans, a spoonful of peas.

Granny's teeth no longer fit, and she has to bite sideways, like a cat. She wears the lower teeth only during meals, but she will not get new ones. She says it would be wasteful to be buried with a new three-hundred-dollar set of teeth. In between bites, Granny guzzles iced tea from a Kentucky Lakes mug. "That slaw don't have enough sugar in it," she says. "It makes my mouth draw up." She smacks her lips.

Nancy says, "I've heard the food is really good at the Orchard Acres Rest Home."

Granny does not reply for a moment. She is working on a chicken gristle, which causes her teeth to clatter. Then she says, "I ain't going nowhere."

"Mother and Daddy are moving back into their house. You don't want to stay here by yourself, do you?" Nancy's voice sounds hollow to her.

"I'll be all right. I can do for myself."

When Granny swallows, it sounds like water spilling from a bucket into a cistern. After Nancy's parents moved in, they covered Granny's old cistern, but Nancy still remembers drawing the bucket up from below. The chains made a sound like crying.

Granny pushes her food with a piece of bread, cleaning her tray. "I can do a little cooking," she says. "I can sweep."

"Try this boiled custard, Granny. I made it just for you. Just the way you used to make it."

"It ain't yaller enough," says Granny, tasting the custard. "Store-bought eggs."

When she finishes, she removes her lower teeth and sloshes them in a plastic tumbler on the bedside table. Nancy looks 
away. On the wall are Nancy's high school graduation photograph and a picture of Jesus. Nancy looks sassy; her graduation hat resembles a tilted lid. Jesus has a halo, set at about the same angle.

Now Nancy ventures a question about the pictures hidden behind the closet wall. At first Granny is puzzled. Then she seems to remember.

"They're behind the stovepipe," she says. Grimacing with pain, she stretches her legs out slowly, and then, holding her head, she sinks back into her pillows and draws the quilt over her shoulders. "I'll look for them one of these days-when I am able."

Jack photographs weeds twigs, pond reflections, silhouettes of Robert against the sun with his arms flung out like a scarecrow's. Sometimes he works in the evenings in his studio at home, drinking tequila sunrises and composing bizarre still lifes with light bulbs, wine bottles, Tinker Toys, Lucite cubes. He makes arrangements of gourds look like breasts.

On the day Nancy tried to explain to Jack about her need to save Granny's pictures, a hailstorm interrupted her. It was the only hailstorm she had ever seen in the North, and she had forgotten all about them. Granny always said a hailstorm meant that God was cleaning out his icebox. Nancy stood against a white Masonite wall mounted with a new series of photographs and looked out the window at tulips being smashed. The ice pellets littered the ground like shattered glass. Then, as suddenly as it had arrived, the hailstorm was over.

"Pictures didn't use to be so common," Nancy said. Jack's trash can was stuffed with rejected prints, and Robert's face was crumpled on top. "I want to keep Granny's pictures as reminders."

"If you think that will solve anything," said Jack, squinting at a negative he was holding against the light.

"I want to see if she has one of Nancy Culpepper."

"That's you."

"There was another one. She was a great-great-aunt or 
"There was another one. She was a great-great-aunt or something, on my daddy's side. She had the same name as mine."

"There's another one of you?" Jack said with mock disbelief.

"I'm a reincarnation," she said, playing along.

"There's nobody else like you. You're one of a kind."

Nancy turned away and stared deliberately at Jack's pictures, which were held up by clear-headed pushpins, like translucent eyes dotting the wall. She examined them one by one, moving methodically down the row-stumps, puffballs, tree roots, close-ups of cat feet.

Nancy first learned about her ancestor on a summer Sunday a few years before, when she took her grandmother to visit the Culpepper graveyard, beside an oak grove off the Paducah highway. The old oaks had spread their limbs until they shaded the entirecemetery, and the tombstones poked through weeds like freak mushrooms. Nancy wandered among the graves, while Granny stayed beside her husband's gravestone. It had her own name on it too, with a blank space for the date.

Nancy told Jack afterward that when she saw the stone marked "NANCY CULPEPPER, 1833-1905," she did a double take. "It was like time-lapse photography," she said. "I mean, I was standing there looking into the past and the future at the same time. It was weird."

"She wasn't kin to me, but she lived down the road," Granny explained to Nancy. "She was your granddaddy's aunt."

"Did she look like me?" Nancy asked.

"I don't know. She was real old." Granny touched the stone, puzzled. "I can't figure why she wasn't buried with her husband's people," she said.

On Saturday, Nancy helps her parents move some of their furniture to the house next door. It is only a short walk, but when the truck is loaded they all ride in it, Nancy sitting between her parents. The truck's muffler sounds like thunder, and they drive without speaking. Daddy backs up to the porch.

The paint on the house is peeling, and the latch of the storm 
door is broken. Daddy pulls at the door impatiently, saying, "I sure wish I could burn down these old houses and retire to Arizona." For as long as Nancy can remember, her father has been sending away for literature on Arizona.

Her mother says, "We'll never go anywhere. We've got our dress tail on a bedpost."

"What does that mean?" asks Nancy, in surprise.

"Use to, if a storm was coming, people would put a bedpost on a child's dress tail, to keep him from blowing away. In other words, we're tied down."

"That's funny. I never heard of that."

"I guess you think we're just ignorant." Mother says. "The way we talk."

"No, I don't."

Daddy props the door open, and Nancy helps him ease a mattress over the threshold. Mother apologizes for not being able to lift anything.

"I'm in your way," she says, stepping off the porch into a dead canna bed.

Nancy stacks boxes in her old room. It seems smaller than she remembered, and the tenants have scarred the woodwork. Mentally, she refurnishes the room-the bed by the window, the desk opposite. The first time Jack came to Kentucky he slept here, while Nancy slept on the couch in the living room. Now Nancy recalls the next day, as they headed west, with Jack accusing her of being dishonest, foolishly trying to protect her parents. "You let them think you're such a goody-goody, the ideal daughter," he said. "I bet you wouldn't tell them if you made less than an A."

Nancy's father comes in and runs his hand across the ceiling, gathering up strings of dust. Tugging at a loose piece of door facing, he says to Nancy, "Never trust renters. They won't take care of a place."

"What will you do with Granny's house?"

"Nothing. Not as long as she's living."

"Will you rent it out then?"

"No. I won't go through that again." He removes his cap 
and smooths his hair, then puts the cap back on. Leaning against the wall, he talks about the high cost of the nursing home. "I never thought it would come to this," he says. "I wouldn't do it if there was any other way."

"You don't have any choice," says Nancy.

"The government will pay you to break up your family," he says. "If I get like your granny, I want you just to take me out in the woods and shoot me."

"She told me she wasn't going," Nancy says.

"They've got a big recreation room for the ones that can get around," Daddy says. "They've even got disco dancing."

When Daddy laughs, his voice catches, and he has to clear his throat. Nancy laughs with him. "I can just see Granny disco dancing. Are you sure you want me to shoot you? That place sounds like fun."

They go outside, where Nancy's mother is cleaning out a patch of weed-choked perennials. "I planted these iris the year we moved," she says. North."

"They're pretty," says Nancy. "I haven't seen that color up

Mother stands up and shakes her foot awake. "I sure hope $y$ 'all can move down here," she says. "It's a shame you have to be so far away. Robert grows so fast I don't know him."

"We might someday. I don't know if we can."

"Looks like Jack could make good money if he set up a studio in town. Nowadays people want fancy pictures."

"Even the school pictures cost a fortune," Daddy says.

"Jack wants to free-lance for publications," says Nancy. "And there aren't any here. There's not even a camera shop within fifty miles."

"But people want pictures," Mother says. "They've gone back to decorating living rooms with family pictures. In antique frames."

Daddy smokes a cigarette on the porch, while Nancy circles the house. A beetle has infested the oak trees, causing clusters of leaves to turn brown. Nancy stands on the concrete lid of an old cistern and watches crows fly across a cornfield. In the 
distance a series of towers slings power lines across a flat sea of soybeans. Her mother is talking about Granny. Nancy thinks of Granny on the telephone, the day of her wedding, innocently asking, "What are you going to cook for your wedding breakfast?" Later, seized with laughter, Nancy told Jack what Granny had said.

"I almost said to her, 'We usually don't eat breakfast, we sleep so late!""

Jack was busy blowing up balloons. When he didn't laugh, Nancy said, "Isn't that hilarious? She's really out of the nineteenth century."

"You don't have to make me breakfast," said Jack.

"In her time, it meant something really big," Nancy said helplessly. "Don't you see?"

Now Nancy's mother is saying, "The way she has to have that milk of magnesia every night, when I know good and well she don't need it. She thinks she can't live without it."

"What's wrong with her?" asks Nancy.

"She thinks she's got a knot in her bowels. But ain't nothing wrong with her but that head-swimming and arthritis." Mother jerks a long morning glory vine out of the marigolds. "Hardening of the arteries is what makes her head swim," she says.

"We better get back and see about her," Daddy says, but he does not get up immediately. The crows are racing above the power lines.

Later, Nancy spreads a Texaco map of the United States out on Granny's quilt. "I want to show you where I live," she says. "Philadelphia's nearly a thousand miles from here."

"Reach me my specs," says Granny, as she struggles to sit up. "How did you get here?"

"Flew. Daddy picked me up at the airport in Paducah."

"Did you come by the bypass or through town?"

"The bypass," says Nancy. Nancy shows her where Pennsylvania is on the map. "I flew from Philadelphia to Louisville to Paducah. There's California. That's where Robert was born." 
"I haven't seen a geography since I was twenty years old," Granny says. She studies the map, running her fingers over it as though she were caressing fine material. "Law, I didn't know where Floridy was. It's way down there."

"I've been to Florida," Nancy says.

Granny lies back, holding her head as if it were a delicate china bowl. In a moment she says, "Tell your mamma to thaw me up some of them strawberries I picked."

"When were you out picking strawberries, Granny?"

"They're in the freezer of my refrigerator. Back in the back. In a little milk carton." Granny removes her glasses and waves them in the air.

"Larry was going to comeand play with me, but he couldn't come," Robert says to Nancy on the telephone that evening. "He had a stomachache."

"That's too bad. What did you do today?"

"We went to Taco Bell and then we went to the woods so Daddy could take pictures of Indian pipes."

"What are those?"

"I don't know. Daddy knows."

"We didn't find any," Jack says on the extension. "I think it's the wrong time of year. How's Kentucky?"

Nancy tells Jack about helping her parents move. "My bed is gone, so tonight I'll have to sleep on a couch in the hallway," she says. "It's really dreary here in this old house. Everything looks so bare."

"How's your grandmother?"

"The same. She's dead set against that rest home, but what can they do?"

"Do you still want to move down there?" Jack asks.

"I don't know."

"I know how we could take the chickens to Kentucky," says Robert in an excited burst.

"How?"

"We could give them sleeping pills and then put them in the trunk so they'd be quiet." 
"That sounds gruesome," Jack says.

Nancy tells Robert not to think about moving. There is static on the line. Nancy has trouble hearing Jack. "We're your family too," he is saying.

"I didn't mean to abandon you," she says.

"Have you seen the pictures yet?"

"No. I'm working up to that."

"Nancy Culpepper, the original?"

"You bet," says Nancy, a little too quickly. She hears Robert hang up. "Is Robert O.K.?" she asks through the static.

"Oh, sure."

"He doesn't think I moved without him?"

"He'll be all right."

"He didn't tell me good-bye."

"Don't worry," says Jack.

"She's been after me about those strawberries till I could wring her neck," says Mother as she and Nancy are getting ready for bed. "She's talking about some strawberries she put up in nineteen seventy-one. I've told her and told her that she eat them strawberries back then, but won't nothing do but for her to have them strawberries."

"Give her some others," Nancy says.

"She'd know the difference. She don't miss a thing when it comes to what's hers. But sometimes she's just as liable to forget her name."

Mother is trembling, and then she is crying. Nancy pats her mother's hair, which is gray and wiry and sticks out in sprigs. Wiping her eyes, Mother says, "All the kinfolks will talk. 'Look what they done to her, poor helpless thing.' It'll probably kill her, to move her to that place."

"When you move back home you can get all your antiques out of the barn," Nancy says. "You'll be in your own house again. Won't that be nice?"

Mother doesn't answer. She takes some sheets and quilts from a closet and hands them to Nancy. "That couch lays good," she says. 
When Nancy wakes up, the covers are on the floor, and for a moment she does not remember where she is. Her digital watch says $2: 43$. Then it tells the date. In the darkness she has no sense of distance, and it seems to her that the red numerals could be the size of a billboard, only seen from far away.

Jack has told her that this kind of insomnia is a sign of depression, while the other kind-inability to fall asleep at bedtime-is a sign of anxiety. Nancy always thought he had it backward, but now she thinks he may be right. A flicker of distant sheet lightning exposes the bleak walls with the suddenness of a flashbulb. The angles of the hall seem unfamiliar, and the narrow couch makes Nancy feel small and alone. When Jack and Robert come to Kentucky with her, they all sleep in the living room, and in the early morning Nancy's parents pass through to get to the bathroom. "We're just one big happy family," Daddy announces, to disguise his embarrassment when he awakens them. Now, for some reason, Nancy recalls Jack's strange still lifes, and she thinks of the black irises and the polished skulls of cattle suspended in the skies of O'Keeffe paintings. The irises are like thunderheads. The night they were married, Nancy and Jack collapsed into bed, falling asleep immediately, their heads swirling. The party was still going on, and friends from New York were staying over. Nancy woke up the next day saying her new name, and feeling that once again, in another way, she had betrayed her parents. "The one time they really thought they knew what I was doing, they didn't at all," she told Jack, who was barely awake. The visitors had gone out for the Sunday newspapers, and they brought back doughnuts. They had doughnuts and wine for breakfast. Someone made coffee later.

In the morning, a slow rain blackens the fallen oak branches in the yard. In Granny's room the curtains are gray with shadows. Nancy places an old photograph album in Granny's lap. Silently, Granny turns pages of blank-faced babies in long white dresses like wedding gowns. Nancy's father is a boy in a sailor suit. Men and women in pictures the color of cafe' au 
lait stand around picnic tables. The immense trees in these settings are shaggy and dark. Granny cannot find Nancy Culpepper in the album. Quickly, she flips past a picture of her husband. Then she almost giggles as she points to a girl. "That's me."

"I wouldn't have recognized you, Granny."

"Why, it looks just like me." Granny strokes the picture, as though she were trying to feel the dress. "That was my favorite dress," she says. "It was brown poplin, with grosgrain ribbon and self-covered buttons. Thirty-two of them. And all those tucks. It took me three weeks to work up that dress."

Nancy points to the pictures one by one, asking Granny to identify them. Granny does not notice Nancy writing the names in a notebook. Aunt Sass, Uncle Joe, Dove and Pear Culpepper, Hortense Culpepper. TB."

"Hort Culpepper went to Texas," says Granny. "She had

"Tell me about that," Nancy urges her.

"There wasn't anything to tell. She got homesick for her mammy's cooking." Granny closes the album and falls back against her pillows, saying, "All those people are gone."

While Granny sleeps, Nancy gets a flashlight and opens the closet. The inside is crammed with the accumulation of decades-yellowed newspapers, boxes of greeting cards, bags of string, and worn-out stockings. Granny's best dress, a blue bonded knit she has hardly worn, is in plastic wrapping. Nancy pushes the clothing aside and examines the wall. To her right, a metal pipe runs vertically through the closet. Backing up against the dresses, Nancy shines the light on the corner and discovers a large framed picture wedged behind the pipe. By tugging at the frame, she is able to work it gradually through the narrow space between the wall and the pipe. In the picture a man and woman, whose features are sharp and clear, are sitting expectantly on a brocaded love seat. Nancy imagines that this is a wedding portrait.

In the living room, a TV evangelist is urging viewers to call him, toll free. Mother turns the TV off when Nancy appears 
with the picture, and Daddy stands up and helps her hold it near a window.

"I think that's Uncle John!" he says excitedly. "He was my favorite uncle."

"They're none of my people," says Mother, studying the picture through her bifocals.

"He died when I was little, but I think that's him," says Daddy. "Him and Aunt Lucy Culpepper."

"Who was she?" Nancy asks.

"Uncle John's wife."

"I figured that," says Nancy impatiently. "But who was she?"

"I don't know." He is still looking at the picture, running his fingers over the man's face.

Back in Granny's room, Nancy pulls the string that turns on the ceiling light, so that Granny can examine the picture. Granny shakes her head slowly. "Inever saw them folks before in all my life."

Mother comes in with a dish of strawberries.

"Did I pick these?" Granny asks.

"No. You eat yours about ten years ago," Mother says.

Granny puts in her teeth and eats the strawberries in slurps, missing her mouth twice. "Let me see them people again," she says, waving her spoon. Her teeth make the sound of a baby rattle.

"Nancy Hollins," says Granny. "She was a Culpepper."

"That's Nancy Culpepper?" cries Nancy.

"That's not Nancy Culpepper," Mother says. "That woman's got a rat in her hair. They wasn't in style back when Nancy Culpepper was alive."

Granny's face is flushed and she is breathing heavily. "She was a real little-bitty old thing," she says in a high, squeaky voice. "She never would talk. Everybody thought she was curious. Plumb curious."

"Are you sure it's her?" Nancy says.

"If I'm not mistaken."

"She don't remember," Mother says to Nancy. "Her mind 


\section{Appalachian Emigration}

gets confused."

Granny removes her teeth and lies back, her bones grinding. Her chest heaves with exhaustion. Nancy sits down in the rocking chair, and as she rocks back and forth she searches the photograph, exploring the features of the young woman, who is wearing an embroidered white dress, and the young man, in a curly beard that starts below his chin, framing his face like a ruffle. The woman looks frightened-of the camera perhapsbut nevertheless her deep-set eyes sparkle like shards of glass. This young woman would be glad to dance to "Lucy in the Sky with Diamonds" on her wedding day, Nancy thinks. The man seems bewildered, as if he did not know what to expect, marrying a woman who has her eyes fixed on something so far away.

\section{Nancy Culpepper}

1. Both Nancy and her husband, a photographer, have an interest in pictures. Why, then, does Nancy have to explain her need to save Granny's pictures? Why does she have this need?

2. This story contrasts Nancy's present life with that of the past. How are they different?

3. How did Nancy react when she saw the stone marked "Nancy Culpepper, 1833-1905"?

4. This story does not have the usual conflict which is present in many short stories; instead it subordinates conflict to revelation of character. What do you learn about Nancy Culpepper? 
JIM WAYNE MILLER (1936- ）

A native of western North Carolina, Jim Wayne Miller earned his undergraduate degree at Berea College in Kentucky. He continued his studies at Vanderbilt and received his Ph.D in both German and American literature in 1965 . While at Vanderbilt, Miller studied under Fugitive poet Donald Davidson.

At present, Dr. Miller is a professor of German language and literature at Western Kentucky University. His stature and reputation as a poet have grown steadily since his first volume of poetry, Copperhead Cane, was published in 1964. His other collections are Dialogue With A Dead Man, The Mountains Have Come Closer, Vein of Words, and Nostalgia for 70 . He received the Thomas Wolfe Award in 1985 for The Mountains Have Come Closer.

"Turn Your Radio On" is about a kind of homesickness common to those who emigrated to northern cities. 


\section{Turn Your Radio On}

I

He couldn't hear his own thoughts in the city that never slept. Like a voice on a far-off radio station, his thoughts rose and fell in a storm of static. The city's rush and roar even poured through his dreams, boiling up like a waterfall.

Asleep or waking, he tried to keep a sense of direction south. Lying awake in the smoky carbon darkness of northern nights facing east, he kept a knowledge, like a book under his pillow,

that the mountains lay to his right, beyond the mills and warehouses.

But sometimes he'd come awake in darkness and find the room

had turned in the slow current of his sleep. He would not rest again until he'd righted the room, and sleep was drifting away from the waterfall's roar toward the quietness of mountains.

But he never drifted home before he woke. He felt so stilled inside, a breathing silence. It was as if his thoughts had been a friend, a buddy who went everywhere with him. Now he turned and found that old companion hadn't followed him here.

Sometimes he'd sit for hours looking through a shoebox of family photographs: his grandfather leading a pair of Walker foxhounds; the old man atop a boulder in the Bearwallow

holding his squirrel gun like a walking stick, or on the porch 
with his grandmother, both of them sitting in split-bottom chairs.

Weathered and home-made like the chairs they sat in, and like the house

and barn, so comfortably in place, they looked like one another.

Something about the way they sat spoke to him through his own thoughts

all the way from the mountains, like a powerful transmitter: this place

belongs to us, their faces said, and we belong to it.

When it's time, we come out on this porch and take our ease, and talk, as naturally as treefrogs in the poplars sing toward dark.

\section{Turn Your Radio On}

1. The poet compares the sound of the city to a waterfall. Is this a valid comparison? Explain.

2. Discuss the line in the fourth stanza "It was as if his thoughts had been a friend...."

3 In what way are the mountains like a powerful transmitter to someone who lives in the city?

4. Have you ever been separated from your home and family like the person in the poem? What did you miss most during this separation? 
BORDEN DEAL (1922-1984)

Born in northeastern Mississippi, Borden Deal spent his youth working in a circus, on a showboat, and in the Civilian Conservation Corps. Following Navy service, he earned a B.A. from the University of Alabama.

He was a correspondent for Associated Films and a radio copywriter before becoming a full-time writer in 1955. He won a Guggenhiem Fellowship in 1957. His short stories are anthologized in Best American Short Stories of 1949 and 1962 and in several textbooks. More than 100 of his short stories have appeared in popular and literary magazines. Translated into more than twenty languages, his stories have been adapted for film, stage, and radio. Healso published fourteen novels, some under the pseudonym Lee Borden.

"Antaeus" was a Greek god whose strength came from keeping his feet solidly on the earth. This is a story about T.J., a southern farm boy removed to a northern industrial city, who comes to realize that he must leave the city and find a place where he can dig his toes into the soil.

\section{Antaeus}

This was during the wartime, when lots of people were coming North for jobs in factories and war industries, when 
people moved around a lot more than they do now, and sometimes kids were thrown into new groups and new lives that were completely different from anything they had ever known before. I remember this one kid, T.J. his name was, from somewhere down South, whose family moved into our building during that time. They'd come North with everything they owned piled into the back seat of an old-model sedan that you wouldn't expect could make the trip, with T.J. and his three younger sisters riding shakingly on top of the load of junk.

Our building was just like all the others there with families crowded into a few rooms, and I guess there were twenty-five or thirty kids about my age in that one building. Of course, there were a few of us who formed a gang and ran together all the time after school, and I was the one who brought T.J. in and started the whole thing.

The building right next door to us was a factory where they made walking dolls. It was a low building with a flat, tarred roof that had a parapet all around it about head-high, and we'd found out a long time before that no one, not even the watchman, paid any attention to the roof because it was higher than any of the other buildings around. So my gang used the roof as a headquarters. We could get up there by crossing over to the fire escape from our own roof on a plank and then going on up. It was a secret place for us, where nobody else could go without our permission.

I remember the day I first took T.J. up there to meet the gang. He was a stocky, robust kid with a shock of white hair, nothing sissy about him except his voice; he talked in this slow, gentle voice like you never heard before. He talked different from any of us and you noticed it right away. But I liked him anyway, so I told him to come on up.

We climbed up over the parapet and dropped down on the roof. The rest of the gang were already there.

"Hi," I said. I jerked my thumb at T.J. "He just moved into the building yesterday."

He just stood there, not scared or anything, just looking, like the first time you see somebody you're not sure you're 
going to like.

"Hi," Blackie said. "Where are you from?"

"Marion County," T.J. said.

We laughed. "Marion County?" I said. "Where's that?"

He looked at me for a moment like I was a stranger, too. "It's in Alabama," he said, like I ought to know where it was.

"What's your name?" Charley said.

"T.J.," he said, looking back at him. He had pale blue eyes that looked washed-out, but he looked directly at Charley, waiting for his reaction. He'll be all right, I thought. No sissy in him, except that voice. Who ever talked like that?

"T.J.," Blackie said. "That's just initials. What's your real name? Nobody in the world has just initials."

"I do," he said. "And they're T.J. That's all the name I got."

His voice was resolute with the knowledge of his rightness, and for a moment no one had anything to say. T.J. looked around at the rooftop and down at the black tar under his feet. "Down yonder where I come from," he said, "we played out in the woods. Don't you-all have no woods around here?"

"Naw," Blackie said. "There's a park a few blocks over, but it's full of kids and cops and old women. You can't do a thing."

T.J. kept looking at the tar under his feet. "You mean you ain't got no fields to raise nothing in?-no watermelons or nothing?"

"Naw," I said scornfully. "What do you want to grow something for? The folks can buy everything they need at the store."

He looked at me again with that strange unknowing look. "In Marion County," he said, "I had my own acre of cotton and my own acre of corn. It was mine to plant and make ever' year."

He sounded like it was something to be proud of, and in some obscure way it made the rest of us angry. Blackie said, "Who'd want to have their own acre of cotton and corn? That's just work. What can you do with an acre of cotton and corn?"

T.J. looked at him. "Well, you get part of the bale offen your acre," he said seriously. "And I fed my acre of corn to my calf."

We didn't really know what he was talking about, so we were more puzzled than angry; otherwise, I guess, we'd have 
chased him off the roof and wouldn't let him be a part of our gang. But he was strange and different, and we were all attracted by his stolid sense of rightness and belonging, maybe by the strange softness of his voice contrasting our own tones of speech into harshness.

He moved his foot against the black tar. "We could make our own field right here," he said softly, thoughtfully. "Come spring we could raise us what we want to-watermelons and garden truck and no telling what all."

"You'd have to be a good farmer to make these tar roofs grow any watermelons," I said. We all laughed.

But T.J. looked serious. "We could haul us some dirt up here," he said. "And spread it out even and water it, and before you know it, we'd have us a crop in here." He looked at us intently. "Wouldn't that be fun?"

They wouldn't let us," Blackie said quickly.

"I thought you said this was you-all's roof," T.J. said to me. "That you-all could do anything you wanted to up here."

"They've never bothered us," I said. I felt the idea beginning to catch fire in me. It was a big idea, and it took a while for it to sink in; but the more I thought about it, the better I liked it. "Say," I said to the gang. "He might have something there. Just make us a regular roof garden, with flowers and grass and trees and everything. And all ours, too," I said. "We wouldn't let anybody up here except the ones we wanted to."

"It'd take a while to grow trees," T.J. said quickly, but we weren't paying any attention to him. They were all talking about it suddenly, all excited with the idea after I'd put it in a way they could catch hold of it. Only rich people had roof gardens, we knew, and the idea of our own private domain excited them.

"We could bring it up in sacks and boxes," Blackie said. "We'd have to do it while the folks weren't paying any attention to us, for we'd have to come up to the roof of our building and then cross over with it."

"Where could we get the dirt?" somebody said worriedly.

"Out of those vacant lots over close to school," Blackie said. 
"Nobody'd notice if we scraped it up."

I slapped T.J. on the shoulder. "Man, you had a wonderful idea," I said, and everybody grinned at him, remembering that he had started it. "Our own private roof garden."

He grinned back. "It'll be ourn," he said. "All ourn." Then he looked thoughtful again. "Maybe I can lay my hands on some cotton seed, too. You think we could raise us some cotton?"

We'd started big projects before at one time or another, like any gang of kids, but they'd always petered out for lack of organization and direction. But this one didn't; somehow or other T.J. kept it going all though the winter months. He kept talking about the watermelons and cotton we'd raise, come spring, and when even that wouldn't work, he' $d$ switch around to my idea of flowers and grass and trees, though he was always honest enough to add that it'd take a while to get any trees started. He always had it on his mind and he'd mention it in school, getting them lined up to carry dirt that afternoon, saying in a casual way that he reckoned a few more weeks ought to see the job through.

Our little area of private earth grew slowly. T.J. was smart enough to start in one corner of the building, heaping up the carried earth two or three feet thick so that we had an immediate result to look at, to contemplate with awe. Some of the evenings T.J. alone was carrying earth up to the building, the rest of the gang distracted by other enterprises or interests, but T.J. kept plugging along on his own, and eventually we'd all come back to him again and then our own little acre would grow more rapidly.

He was careful about the kind of dirt he'd let us carry up there, and more than once dumped a sandy load over the parapet into the areaway below because it wasn't good enough. He found out the kinds of earth in all the vacant lots for blocks around. He'd pick it up and feel it and smell it, frozen though it was sometimes, and then he'd say it was good growing soil or it wasn't worth anything, and we'd have to go 
on to somewhere else.

Thinking about it now, I don't see how he kept us at it. It was hard work, lugging paper sacks and boxes of dirt all the way up the stairs of our own building, keeping out of the way of the grownups so they wouldn't catch on to what we were doing. They probably wouldn't have cared, for they didn't pay much attention to us, but we wanted to keep it a secret anyway. Then we had to go through the trapdoor to our roof, teeter over a plank to the fire escape, then climb two or three stories to the parapet and drop them down onto the roof. All that for a small pile of earth that sometimes didn't seem worth the effort. But T.J. kept the vision bright within us, his words shrewd and calculated toward the fulfillment of his dream; and he worked harder than any of us. He seemed driven toward a goal that we couldn't see, a particular point in time that would be definitely marked by signs and wonders that only he could see.

The laborious earth just lay there during the cold months, inert and lifeless, the clods lumpy and cold under our feet when we walked over it. But one day it rained, and afterwards there was a softness in the air, and the earth was live and giving again with moisture and warmth.

That evening T.J. smelled the air, his nostrils dilating with the odor of the earth under his feet. "It's spring," he said, and there was a gladness rising in his voice that filled us all with the same feeling. "It's mighty late for it, but it's spring. I'd just about decided it wasn't never gonna get here at all."

We were all sniffing at the air, too, trying to smell it the way that T.J. did, and I can still remember the sweet odor of earth under our feet. It was the first time in my life that spring and spring earth had meant anything to me. I looked at T.J. then, knowing in a faint way the hunger within him through the toilsome winter months, knowing the dream that lay behind his plan. He was a new Antaeus preparing his own bed of strength.

"Planting time," he said. "We'll have to find some seed."

"What do we do?" Blackie said. "How do we do it?"

"First we'll have to break up the clods," T.J. said. "That 
won't be hard to do. Then we plant the seeds, and after a while they come up. Then you got a crop." He frowned. "But you ain't got it raised yet. You got to tend it and hoe it and take care of it, and all the time it's growing and growing, while you're awake and while you're asleep. Then you lay it by when it's growed and let ripen, and then you got you a crop."

"There's those wholesale seed houses over on Sixth," I said. "We could probably swipe some grass seed over there."

T.J. looked at the earth. "You-all seem mighty set on raising some grass," he said. "I ain't never put no effort into that. I spent all my life trying not to raise grass."

"But it's pretty," Blackie said. "We could play on it and take sunbaths on it. Like having our own lawn. Lots of people got lawns."

"Well," T.J. said. He looked at the rest of us, hesitant for the first time. He kept on looking at us for a moment. "I did have it in mind to raise some corn and vegetables. But we'll plant grass."

He was smart. He know where to give in. And I don't suppose it made any difference to him, really. He just wanted to grow something, even if it was grass.

"Of course," he said, "I do think we ought to plant a row of watermelons. They'd be mighty nice to eat while we was alaying on that grass."

We all laughed. "All right," I said. "We'll plant us a row of watermelons."

Things went very quickly then. Perhaps half the roof was covered with earth, the half that wasn't broken by ventilators, and we swiped pocketfuls of grass seed from the open bins in the wholesale seed house, mingling among the buyers on Saturdays and during the school lunch hour. T.J. showed us how to prepare the earth, breaking up the clods and smoothing it and sowing the grass seed. It looked rich and black now with moisture, receiving of the seed, and it seemed that the grass sprang up overnight, pale green in the early spring.

We couldn't keep from looking at it, unable to believe that we had created this delicate growth. We looked at T.J. with un- 
derstanding now, knowing the fulfillment of the plan he had carried along within his mind. We had worked without full understanding of the task, but he had known all the time.

We found that we couldn't walk or play on the delicate blades, as we had expected to, but we didn't mind. It was enough just to look at it, to realize that it was the work of our own hands, and each evening the whole gang was there, trying to measure the growth that had been achieved that day.

One time a foot was placed on the plot of ground, one time only, Blackie stepping onto it with sudden bravado. Then he looked at the crushed blades and there was shame in his face. He did not do it again. This was his grass, too, and not to be desecrated. No one said anything, for it was not necessary.

T.J. had reserved a small section for watermelons, and he was still trying to find some seed for it. The wholesale house didn't have any watermelon seeds, and we didn't know where we could lay our hands on them. T.J. shaped the earth into mounds, ready to receive them, three mounds lying in a straight line along the edge of the grass plot.

We had just about decided that we'd have to buy the seeds if we were to get them. It was a violation of our principles, but we were anxious to get the watermelons started. Somewhere or other, T.J. got his hands on a seed catalog and brought it one evening to our roof garden. "Look!"

"We can order them now," he said, showing us the catalog.

We all crowded around, looking at the fat, green watermelons pictured in full color on the pages. Some of them were split open, showing the red, tempting meat, making our mouths water.

"Now we got to scrape up some seed money," T.J. said, looking at us. "I got a quarter. How much you-all got?"

We made up a couple of dollars among us and T.J. nodded his head. "That'll be more than enough. Now we got to decide what kind to get. I think them Kleckley Sweets. What do youall think?"

He was going into esoteric matters beyond our reach. We 
hadn't even known there were different kinds of watermelons. So we just nodded our heads and agreed that yes, we thought the Kleckley Sweets too.

I'll order them tonight," T.J. said. "We ought to have them in a few days."

"What are you boys doing up here?" an adult voice said behind us.

It startled us, for no one had ever come up here before in all the time we had been using the roof of the factory. We jerked around and saw three men standing near the trap door at the other end of the roof. They weren't policemen or night watchmen, but three men in plump business suits, looking at us. They walked toward us.

"What are you boys doing up here?" the one in the middle said again.

We stood still, guilt heavy among us, levied by the tone of voice, and looked at the three strangers.

The men stared at the grass flourishing behind us. "What's this?" the man said. "How did this get up here?"

"Sure is growing good, ain't it?" T.J. said conversationally. "We planted it."

The men kept looking at the grass as if they didn't believe it. It was a thick carpet over the earth now, a patch of deep greenness startling in the sterile industrial surroundings.

"Yes, sir," T.J. said proudly. "We toted that earth up here and planted that grass." He fluttered the seed catalog. "And we're just fixing to plant us some watermelon."

The man looked at him then, his eyes strange and faraway. "What do you mean, putting this on the roof of my building?" he said. "Do you want to go to jail?"

T.J. looked shaken. The rest of us were silent, frightened by the authority of his voice. We had grown up aware of adult authority, of policemen and night watchmen and teachers, and this man sounded like all the others. But it was a new thing to T.J.

"Well, you wasn't using the roof," T.J. said. He paused a moment and added shrewdly, "So we just thought to pretty it 
up a little bit."

"And sag it so I'd have to rebuild it," the man said sharply. He started turning away, saying to another man beside him, "See that all that junk is shoveled off by tomorrow."

"Yes, sir," the man said.

T.J. started forward. "You can't do that," he said. "We toted it up here, and it's our earth. We planted it and raised it and toted it up here."

The man stared at him coldly. "But it's my building," he said. "It's to be shoveled off tomorrow."

"It's our earth," T.J. said desperately. "You ain't got no right!"

The men walked on without listening and descended clumsily through the trapdoor. T.J. stood looking after them, his body tense with anger, until they had disappeared. They wouldn't even argue with him, wouldn't let him defend his earth-rights.

He turned to us. "We won't let 'em do it," he said fiercely. "We'll stay up here all day tomorrow and the day after that, and we won't let 'em do it."

We just looked at him. We knew there was no stopping it.

He saw it in our faces, and his face wavered for a moment before he gripped it into determination. "They ain't got no right," he said. "It's our earth. It's our land. Can't nobody touch a man's own land."

We kept looking at him, listening to the words but knowing that it was no use. The adult world had descended on us even in our richest dream, and we knew there was no calculating the adult world, no fighting it, no winning against it.

We started moving slowly toward the parapet and the fire escape, avoiding a last look at the green beauty of the earth that T.J. had planted for us, had planted deeply in our minds as well as in our experience. We filed slowly over the edge and down the steps to the plank, T.J. coming last, and all of us could feel the weight of his grief behind us.

"Wait a minute," he said suddenly, his voice harsh with the effort of calling. 
We stopped and turned, held by the tone of his voice, and looked up at him standing above us on the fire escape.

"We can't stop them?" he said, looking down at us, his face strange in the dusky light. "There ain't no way to stop 'em?"

"No," Blackie said with finality. "They own the building."

We stood still for a moment, looking up at T.J., caught into inaction by the decision working in his face. He stared back at us, and his face was pale and mean in the poor light, with a bald nakedness in his skin like cripples have sometimes.

"They ain't gonna touch my earth," he said fiercely. "They ain't gonna lay a hand on it! Come on."

He turned around and started up the fire escape again, almost running against the effort of climbing. We followed more slowly, not knowing what he intended. By the time we reached him, he had seized a board and thrust it into the soil, scooping it up and flinging it over the parapet into the areaway below. He straightened and looked at us.

"They can't touch it," he said. "I won't let 'em lay a dirty hand on it!"

We saw it then. He stooped to his labor again and we followed, the gusts of his anger moving in frenzied labor among us as we scattered along the edge of earth, scooping it and throwing it over the parapet, destroying with anger the growth we had nurtured with such tender care. The soil carried so laboriously upward to the light and the sun cascaded swiftly into the dark areaway, the green blades of grass crumpled and twisted in the falling.

It took less time than you would think; the task of destruction is infinitely easier than that of creation. We stopped at the end, leaving only a scattering of loose soil, and when it was finally over, a stillness stood among the group and over the factory building. We looked down at the bare sterility of black tar, felt the harsh texture of it under the soles of our shoes, and the anger had gone out of us, leaving only a sore aching in our minds like overstretched muscles.

T.J. stood for a moment, his breathing slowing from anger and effort, caught into the same contemplation of destruction 
as all of us. He stooped slowly, finally, and picked up a lonely blade of grass left trampled under our feet and put it between his teeth, tasting it, sucking the greeness out of it into his mouth. Then he started walking toward the fire escape, moving before any of us were ready to move, and disappeared over the edge.

We followed him, but he was already halfway down to the ground, going on past the board where we crossed over, climbing down into the areaway. We saw the last section swing down with his weight, and then he stood on the concrete below us, looking at the small pile of anonymous earth scattered by our throwing. Then he walked across the place where we could see him and disappeared toward the street without glancing back, without looking up to see us watching him.

They did not find him for two weeks.

Then the Nashville police caught him just outside the Nashville freight yards. He was walking along the railroad track, still heading South, still heading home.

As for us, who had no remembered home to call us, none of us ever again climbed the escapeway to the roof.

\section{Antaeus}

1. What is the major conflict in this story?

2. What qualities did T.J. have that enabled him to have his way with the boys?

3. How did the boys get the grass seed they needed? The watermelon seed?

4. In Greek mythology Hercules wrestled the giant Antaeus, son of earth. If the giant touched the earth, he was invincible; therefore, Hercules had to strangle him in the air. In what ways is T.J. like Antaeus? 


\section{Appalachian Emigration}

Illustration No. 10

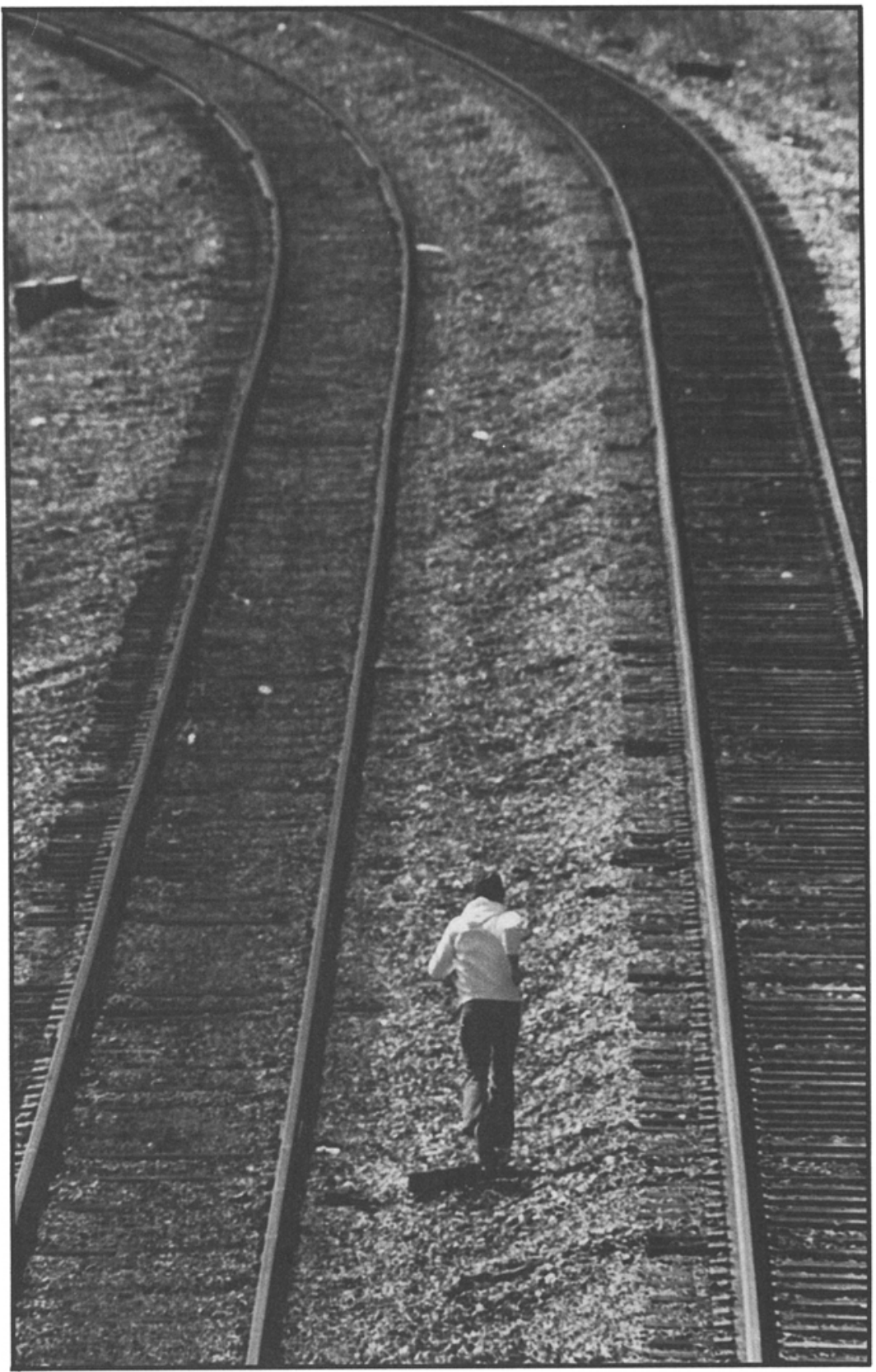


JO CARSON 465

\section{JO CARSON (1946- )}

Jo Carson, a lifelong resident of Johnson City, Tennessee, brings voices from her region to life in her poetry and plays. A graduate of East Tennessee State University, she is associated with the Road Company, a small theatre group based in Johnson City as both a writer and as an actress.

She is a visiting commentator on National Public Radio's program All Things Considered, and performs many of her "People Pieces" for audiences all across America. 
People Pieces: My Brother Estes

My brother Estes

and his cousin Ray

left here for California

the minute the two of them together

had enough money to buy a car.

They were leaving the god-forsaken mountains.

They were gonna' make some money,

gonna' find them California wives.

Well, they did,

both of them.

I gotta' admit

they done right well.

But I got a phone call from Estes

just two days ago.

He's pushing into his fifties now

and you know,

he wants to bring his California wife

and come back home.

All this time, he's called me

his hick sister,

but I knew my chance was coming

cause the mountains speak the loudest

to a person in his middle age

and no matter where he is

or what he's done,

he begins to think of them as home.

You know what I told Estes?

I told him to come on back and try it,

but not to get his hopes too high

cause he don't talk right anymore. 


\section{Brother Estes}

1. Brother Estes' sister observes that Estes does not talk right any more. What other changes might you expect to find in someone who has left Appalachia and moved to California?

2. Why does Estes want to return to the mountains?

3. Discuss the poet's statement that "the mountains speak loudest to a person in middle age." 


\section{GURNEY NORMAN (1937- )}

Gurney Norman's first novel, Divine Rights' Trip, was originally published in The Whole Earth Catalog, a Californiabased publication which he helped edit. The novel tells the story of a young man in the Sixties searching for himself and some inner peace, which he finds only on returning to his home in Kentucky.

The novel, no doubt, portrays some of Norman's own life. A native of eastern Kentucky, he graduated from the University of Kentucky before going off to Stanford University in California to study with the great short story writer Frank $\mathrm{O}^{\prime}$ Connor. His credits include an oral narrative recorded for June Appal records and a short story collection Kinfolks. Norman currently teaches creative writing at the University of Kentucky and conducts summer workshops around the region.

One of the major consciousness-raisers in his native region, Gurney Norman has consistently urged other Appalachian authors to write what they know best. He was instrumental in the formation of the Southern Appalachian Writer's Cooperative.

"A Correspondence" is told in letters exchanged between a mountain woman and her brother. 


\section{A Correspondence from Kinfolks}

Dear Brother Luther,

I know you will be surprised to hear from me it's been so long. How I found you was yet living and where, was Wilgus Collier is from there, who came to rent my upstairs apartment, a nice young traveling man. He says he grew up within a mile of where your daughter live in Knott County, that his aunt is her neighbor and for you to tell her hello. I call it the Lord's miracle that He sent Wilgus Collier to my house a messenger of the only good news I have had in many years. I pray to Him this will reach you and that you will answer and we will be in touch with one another again.

So it's been many years since we were all at home together hasn't it dear Brother? I often think of those old days and wish I was back at home with my loved ones instead of sitting in this lonesome place by myself. Did you know I lived in Phoenix? I have lived here eleven years. My husband Troy bought this house with two apartments and one other with three apartments and moved us here in 1954 when he retired and for my asthma. Then the next year he died of heart trouble and Bright's disease so I have a mighty load to carry by myself. Troy had a boy and girl by his first marriage but they have forgot their old stepmother, and I never had children of my own as you perhaps know. It is lonesome in Phoenix and I breathe with difficulty, and my tenants are the only ones I see and they are not always friendly except Wilgus Collier, a nice young traveling man who the Lord sent to me and put me in touch with you again and oh I hope how soon we can be together again dear Brother, like we were so many years ago when we lived on Cowan Creek. Join me in thanks to God and write soon.

Your loving sister,

Mrs. Drucilla Cornett Toliver

Sweet Sister,

Could not believe your letter at first. I thought it was 
another trick to torment me. I read it, read it again, then had daughter Cleo read it to me to be sure it was true. A big surprise, to think for years I have a sister living after all.

Yes, many years have gone under the bridge since we were all at home together and so happy. Now everything is down to a final proposition it appears like. I have the gout and cataracts. My wife Naomi died two years ago. My younguns are scattered here and yon, except daughter Blanche who died and son Romulus who lost his mind. I live first with one then the other, but mostly daughter Cleo, the others don't want me much. Bad business to be amongst ungrateful children.

Arizona. A mighty fine place I hear. Your man done good by you to leave you so well off. I seen Goldwater on television one night, speaking right from Phoenix. He strikes me as a scoundrel but it showed pictures of Arizona country, the desert and the sunset on some mountains so peaceful and quiet, it sure looked like where I want to be. And I hope how soon we can be together sweet sister, to keep each other company in these terrible times.

Your brother Luther Cornett, Age 79 how old are you by now?

Dear Brother,

I am 72. I have asthma and atherites, bursitis and awful high blood pressure. My fingers hurts now to write this letter and I hope you will be able to read it.

But you have a nice hand write, Brother. You always was a good scholar at Little Engle School. I remember walking to school with you boys, and the way it set back against the hillside, the front end of it on stilts high enough to play under, and the way the willows and the sycamores leaned out over Engle Creek, and wading the creek and the Big Rock we played on that had mint growing around it. I remember an Easter egg hunt at the school. And the fight you had with Enoch Singleton. I know I have forgot a lot of old times but I do remember that school very well and hope to see it when I get back to dear Kentucky. 
Which should not be too long now. My houses are not fancy but they are buying up property right and left here and I have buyers galore to pick from. But I want to get a good price so we can afford ourselves a nice place together somewhere there in Knott County. Do you hear of any places for sale in the Carr Fork section? Who owns the old homeplace now? Maybe we could buy it back and live there again and be like we used to be so many years ago.

I look forward to meeting your Cleo and all your grandchildren. You are so lucky to have grandchildren. I never did even have children but I guess I told you that. Until I learned you were yet living I cried myself to sleep every night with only Jesus for my comfort. But now he has sent me you, and soon we will be re-united in His love, sweet Brother.

\section{In His Holy Name,}

Drucilla Toliver

\section{Sweet Sister,}

So much racket going on here I can't hardly think what to write. It is this way all the time in this house, no peace and quiet. Cleo won't control her younguns. They all promised me my own room before I moved in, but then never give me one, it was all a lure and a trap. I turn the television up full blast to drown them out. After a while you don't hear a loud television but it is still a poor substitute for true quiet like you all must have out west.

The '27 flood got Engle School.

A flood can come and get the rest of this place for all I care. Kentucky is all tore up and gone, Sister. Soon they'll flood Carr Fork and that whole section, including the old homeplace, the government's doing it. You are fortunate to have your property. I used to have property on Hardburly Mountain, two hundred acres, with a good stand of white pine plus a well, dwelling house, barn and good-sized garden. But the strip miners got it all. I lawed the sons of bitches but couldn't do no good. So here I am stuck at Cleo's house, crowded up, no privacy, she can't cook, younguns gone wild, not enough heat, 
and they read my mail before I get it. (You be careful what you say!) Count your blessings in Arizona, sister, none in Kentucky to count. And keep your property, I'll be out there before long to help you run it and we'll get along good for ever more.

Your loving brother,

Luther

Dear Brother,

You would not like Arizona. It is not green and cool here like Kentucky, and Phoenix is difficult of living. I can't tell you too much about Phoenix except that Carson Avenue is a terrible place. I've only seen the downtown part once, in 1956 when the Presbyterians took me down and back one day for a good deed, but it wasn't much then and I doubt that it's any better now.

I want to pick blackberries again, and gather chestnuts and see the laurel when it blooms. I never see anything on Carson Avenue except the motorcycle gang go by. Taxes are awful and the heat and when you call the water company it takes a month to come, and you can't see television because of this sarcastic neighbor Mr. Ortiz who pranks with the electricity.

So I'll be home in a month or two, soon as I settle up my business. You look for us a place to buy. Get it in the country, pick us out a cove off one of those cool hollows and have laurel on it if you can. It would be good to live close to Carr Creek or Troublesome, or maybe even over on North Fork River. I'm not much of a fisherman you always were and I can cook fish. It would be handy if we could buy us a good house already built. But if you feel up to it, and some of your children would help, I'd like to buy a hillside with good timber on it and we could have us a house built out of our own wood, to suit us, and cheaper too. Wouldn't that be something? I'd like to be on the road to see people go by, nice Kentucky neighbors and kinfolks. Last Sunday I was sitting on my porch and a motorcycle man yelled an ugly thing at me and upset me terrible.

And I didn't exactly admire you using bad language in your last letter, Brother. That indicates you might not be saved, 
but I pray you are, but if you aren't tell me the truth about it. Sister Drucilla

Drucilla,

Don't come to Kentucky. I tell you this is a terrible place. The union has pulled out. No work anywhere. They're gouging the hillsides down, stripping and auguring. Ledford Pope's house got totally carried off by a mudslide. The streams are fouled, not a fish this side of Buckhorn Lake, not even any water to speak of except at flood time when there's more than anybody wants. The young folks have mostly moved to Ohio and Indiana to work, and them that's left have no respect for old people, they'd never help us build a house even if we had something to build it out of. Kentucky's timber has been gone since you have. Coal trucks make more racket than motorcycles, and there's no air fit to breathe for the slate dumps burning. Sure no place for asthma sufferers.

I've seen the pictures of Arizona, and read about it. It sounds like all the old folks in the country are retiring out there but me. Damn such business as that, I'm on my way soon as I can accumulate the trainfare. If you've got some extra to send me for expenses I'd be grateful to you, and make it up to you once I got there. I'll rent two apartments from you myself, I want me some room to stretch in. And don't worry about getting downtown. Me and you will take right off the first thing and see all the sights and visit all the retired people in Phoenix and go to shows and ride buses and sit around the swimming pools drinking ice tea.

Sorry for the bad words. Yes, I'm saved. I was a terrible rip-roarer most of my life, but 12 years ago I seen the light and give up all bad habits except cussing. I'm ready to give that up too but see no way to go about it till I get somewhere where there ain't so much to cuss about.

Your brother, Luther

Brother,

I'm not going to live in Arizona. That's all there is to it. 
You don't understand how it is here. Why do you not want me to come home? Are you making up all those bad tales on Kentucky, just to keep me from coming? I don't understand your attitude. A man that would cuss his sister would lie to her too, and the Bible admonishes against oaths and lies. I don't want to boss you but I'll not be bossed myself, and I absolutely will not stay in Arizona.

Drucilla Toliver

Sister,

You say you don't understand my attitude. Well I don't understand a sister that would have two fancy houses and yet turn out a suffering brother to suffer at the hands of mean children and a bad location. You talk like such a Christian. I say do unto others as you want them to do unto you and you're the one with two houses. I didn't cuss you. And I just wonder who is lying to who, for I have seen the pictures of Arizona and read of everybody moving there to retire and be happy. It sounds like you're all out there together plotting to keep me out. Well you won't get away with it and I have one question to ask: have you been getting secret letters from Cleo on the side? It wouldn't surprise me.

\section{Luther Cornett}

Brother,

I still refuse to stay in Arizona, in spite of your insults, and I suggest you read The Beatitudes.

Drucilla Cornett Toliver

Sister,

You and Cleo think you can lure and trap me into staying in Kentucky but you are wrong.

\section{Luther Cornett}

Luther,

You have turned out strange is all I can say, unmindful of 
the needs of others, and if you continue to curse me we might as well forget the whole business.

Drucilla Cornett Toliver

Drucilla,

I have not cussed you but I am about to get around to it. And Cleo and Emmit and Polly and Sarah and R.C. and Little Charles too if they all don't hush their racket. If you don't agree to my coming there then you are right, we might as well forget the whole thing for I absolutely refuse to stay in such a goddamn hell-hole as this.

Luther Cornett

Dear Luther,

Satan moves your tongue and I won't listen, or agree to stay here another week.

Drucilla Toliver

Dear Drucilla,

Then we just as well forget the whole thing.

Mr. Luther O. Cornett

Luther,

Suit yourself.

Mrs. Drucilla Toliver

\section{A Correspondence}

1. What does Drucilla remember and love about life in Knott County?

2. What is the reality of living in Knott County for Luther?

3. There is an old saying, "The grass is greener on the other side of the fence." Explain this saying as it relates to Luther and Drucilla. 


\section{ROBERT PENN WARREN (1905- )}

Born in Guthrie, Kentucky, Robert Penn Warren graduated in 1925 from Vanderbilt University, where he was a member of the Fugitive group of poets. He was strongly influenced by his professors, John Crowe Ransom and Donald Davidson. His studies continued at the University of California, at Yale, and at Oxford as a Rhodes Scholar.

Critic, novelist, short story writer, poet, editor, biographer, and dramatist, he is the only writer ever to receive the Pulitzer Prize for both fiction (All the King's Men, 1946) and poetry (Promises, 1957). He is one of the founders of Southern Review, co-author of several college literature textbooks, and a former professor of English and drama.

Probably best known for his eight novels, Robert Penn Warren, now in his eighties and living in Connecticut, continues to write and receive high honors. In 1985, he was named by Congress as the nation's first Poet Laureate. The title of Poet Laureate is a British tradition dating back hundreds of years. Although the American appointment is much shorter than the British, which is for a lifetime, the purpose is the same: to acknowledge the importance of the poet in a civilized society. Everyone agrees that Robert Penn Warren is the natural choice for this first-time prestigious honor. 


\section{Sitting on Farm Lawn on Sunday Afternoon}

The old, the young-they sit.

And the baby on its blanket

Blows a crystalline

Bubble to float, then burst

Into air's nothingness.

Under the maples they sit,

As the limpid year uncoils

With a motion like motionlessness,

While only a few maple leaves

Are crisping toward yellow

And not too much rust yet

Streaks the far blades of corn.

The big white bulldog dozes

In a patch of private shade.

The afternoon muses onward,

Past work, past week, past season,

Past all the years gone by,

And delicate feminine fingers,

Deft and ivory-white,

And fingers steely, or knobbed

In the gnarl of arthritis, conspire

To untangle the snarl of years

Which are their past, and the past

Of kin who in dark now hide, 
478 Appalachian Emigration

Yet sometimes seem to stare forth

With critical, loving gaze,

Or deeper in darkness weep

At wisdom they learned too late.

Is all wisdom learned too late?

The baby lalls to itself,

For it does not yet know all

The tales and contortions of Time.

Nor do I, who sit here alone,

In another place, and hour.

Sitting On Farm Lawn on Sunday Afternoon

1. What event might have inspired this poem?

2. Discuss the line "Is all wisdom learned too late?"

3. Why does the gathering of several generations of family make us think about change? about time? 


\section{LISA ALTHER (1944- ）}

Born to a surgeon and a former English teacher in Kingsport, Tennessee, an industrial city in the heart of Appalachia, Lisa Alther best knows Appalachia caught between the old ways and the new ways of Middle America, both of which she satirizes.

Educated at Wellesley College, she was an editorial assistant at Atheneum Publishers before Knopf published her first novel Kinflicks in 1976. Since then, she has published two other novels and continues to contribute articles and stories to national magazines.

This excerpt from Kinflicks concerns the protagonist's search for identity. She returns to the cabin of her grandfather, remembering his words and trying to understand her life and the forces that have shaped her.

\section{From Kinflicks}

She tooted the horn gently in the old tattoo her family had always used to indicate to the Cloyds that it was Babcocks going past to the cabin, not vandals and thieves. She drove on for another mile down the ever-narrowing dirt track through a woods of oak and sycamore and sassafras, redbud, poplar, and dogwood-a woods so different in composition from that 
behind Ira's house in Vermont, with its birch and ash and sugar maples, its dozen varieties of evergreen.

Stopping in front of the aluminum gate, she got out and unlocked the chain and drove the Jeep through. She descended the hill into the kudzu-lined bowl which housed the cabin and the pond. The cabin, built of chinked logs and covered by a dull green tin roof, had a patchwork history of occupation. It had been built around 1800 by the original settler of the farmone of the motley breed of horse thieves and adventurers and deserters who had crossed the Blue Ridge Mountains, fleeing the civilized coastal regions of Virginia and North Carolina for the mountainous backwoods of Kentucky and Tennessee and southwest Virginia. By the time her grandfather, Mr. Zed, eluded his destiny as a coal miner and bought the farm, the cabin had been deserted for decades. Mr. Zed rebuilt the cabin and lived there with his wife and his small daughter, Ginny's mother, while his pseudo-antebellum mansion was under construction. When Ginny's mother and father were first married, they lived in the cabin. Ginny herself had been born there. Shortly after Jim's birth, her grandparents had traded her parents the mansion for the cabin. After her grandmother's death, Mr. Zed had spent the rest of his life in virtual seclusion at the cabin, trying to figure out how to undo what he had spent his lifetime doing-founding Hullsport and establishing the factory.

Hence the kudzu. The kudzu vines served a double purpose: First, they held up the red clay sides of the bowl, which were always threatening to collapse into the pond; and secondly, they were an experiment with far-reaching implications in the deranged mind of the aging Mr. Zed. Kudzu was being highly touted at the time by the agricultural extension agents as the wonder vine of the century. Not only did its tenacious roots fix nitrogen in depleted soils; not only did the highprotein foliage make nutritious cattle fodder, but the plant spread so voraciously that only a few starter plants were required to take over an entire hillside.

It was to explore this promise that Ginny's grandfather, his 
scramble of long white hair whipping in the breeze, had carefully placed plants all around the bowl. In no time at all, every object in sight had been swallowed up-bushes, rocks, trees, fences, an old tobacco shed, rusted equipment parts. The vines were six feet deep in spots. Her grandfather had spent most of his twilight years, when his peers were engaged in shuffleboard tournaments at Sun City, Arizona, hacking away with a machete as the kudzu threatened to engulf his front lawn. But he hacked without malice, because he saw kudzu as his secret weapon. He would plant it, under cover of the night, at selected spots around the factory and the town. The vines would silently take hold and begin their stealthy spread. Before Hullsporters were even aware of their existence, the grasping tendrils would choke out all life in the Model City. The site would be returned to Nature.

Word got around town to humor the old man as he crept around furtively planting, and scowling at the smokestacks and holding tanks, and shaking his fist at the encroaching superhighways and shopping malls and housing developments. "Senile," they would say, shaking their heads sadly. "Mr. Zed's done gone mental."

To Ginny, when she would walk up to visit him, he would shake his wild crop of tangled hair and say plaintively, "I never should of left Sow Gap, honey. I was a miner's son. I had no bidness tryin to be nothin else. Lord God, I done made a mess. Virginia, honey, don't you never try to be what you ain't."

"But what am I?" she'd ask him, reviewing her history of being born in a farm cabin in Virginia with a rural southern mother and an industrialist father from Boston, and with refugees from the coal mines for grandparents; growing up in a fake antebellum mansion in a factory town in the New South with a dairy farm out her back door; being christened "Virginia" by her mother in a burst of geographic chauvinism, and "Babcock" by her father, which name emblazoned the walls of a hall at Harvard. Being a human melting pot, to what one god-social or economic or geographic-was she to direct her scattered allegiances? How she had envied her friends at 
public meetings who could stand up and belt out a belligerent version of "Dixie"; on such occasions Ginny herself had sometimes remained seated, sometimes stood but not sung, sometimes sung halfheartedly.

Ginny had decided to put the issue of scattered allegiances behind her and start out fresh when she left Hullsport for Boston. And what had she done since? She'd married a Yankee businessman whose parents were Vermont farmers; she'd taken a hippy army deserter as a lover, if that was the right term for Hawk's relationship to her; she'd been living a surburban life in a small town in Vermont. Given her chance at transcendence, she'd merely re-created the muddle of loyalties she'd left Hullsport to escape.

She got out of the Jeep, lugging her pack and some groceries, and stumbled over dark green kudzu vines all the way to the cabin. The vines had taken over the stone steps and were partway up the log sides of the cabin. Someone hadn't been performing Mr. Zed's former duties with the machete. Stepping firmly on the vines that covered the steps, Ginny wrenched open the front door, walked in, and began opening shutters.

There were veils of cobwebs in the corners and a layer of dust over all horizontal surfaces. Otherwise, the place was relatively neat and inhabitable. She threw the switch on the fuse box, and the various motors in the cabin-the pump, the refrigerator, the hot water heater-started humming on cue. After putting away the groceries in the small kitchen, cheery with its red gingham curtains and hooked rugs, she took a mop and knocked down the spiderwebs and dusted the dark wideplank floors.

The last time she'd been here, a few months before her grandfather's death, her cousin Raymond had arrived for a visit. Raymond was tall and painfully thin with black bags under his eyes and hollows under his cheekbones. His coloring was almost albino, like a crayfish from an underground stream. He talked very little, mostly sat hunched over wheezing. Black lung from the mines, her grandfather explained 
later.

"I'll tell you the truth, Raymond," Mr. Zed said, shaking his bushy white head angrily, "I declare, I rue the day I left Sow Gap!"

"You're plumb crazy iffen you do," Raymond gasped. "Sow Gap like to have killed me. Can't do nothin no more cept sit around tryin to breathe."

"Hullsport is worse than them mines ever was," Mr. Zed insisted. "The air's ever bit as foul, and you can't fish the Crockett no more."

"Hit beats the hell out of them slag heaps up at Sow Gap. I bet you done forgot what hit's like in the pits, Zed. When the pumps don't work and you're stoopin over in a four-foot crawl space with water to your knees hot-wirin a 440 cable with maskin tape?"

"You know what that damn fool Yankee son-in-law of mine is makin at that factory, Raymond? Bombs, that's what. Roof falls is nothin compared to that. It's these Yankee Episcopalians-hell, they're gonna kill us all."

Ginny had returned to Miss Head in Boston the next week more intent than ever on a career as a scholar, so that she need have nothing more to do with either slag heaps or holding tanks. But then she had met Eddie Holzer.

Ginny took her grandfather's machete from over the huge stone fireplace. She went outside and hacked away at the kudzu, tearing it one vine at a time off the cabin and severing it at ground level with a rhythmic sweep of her arm, like Ira's practice golf swings. Gradually she chopped a no-man's land of several feet around the cabin. She was imagining as she swung what it would feel like to live in a rain forest in the Amazon Basin: If your perseverance flagged even briefly, you would disappear in the encroaching undergrowth. Soon she was splattered with pale green kudzu blood. The summer sun was hot; it hung midway between its noon position and the rim of the red clay bowl on the far side of the pond. It would set that evening behind the very spot on the ridge where Mr. Zed was buried, his headstone now swallowed up by the kudzu. 
Ginny walked down to the pond, stepping carefully through the tangled vines, whose relatives she had just executed. A layer of chartreuse scum covered at least a third of the pond surface. She threw off her peasant dress, unlaced her boots, and walked into the water, sinking up to her ankles in the squish on the pond bottom. Farther out, scum clinging to her pubic hair, she lowered herself into the water and began a stately breast stroke, sweeping scum out of her path as she went.

\section{Kinflicks}

1. Discuss Mr. Zed's statement "don't you never try to be what you ain't."

2. Why is Ginny confused about herself?

3. What does Ginny's chopping of the kudzu vine symbolize? What does her swim in the pond symbolize? 


\section{COMPOSITION TOPICS}

1. Write a theme contrasting city and country life. Do you think the different lifestyles are reflected in the people?

2. Write an essay about your dreams and plans for the future. Do you plan to remain in the area where you now live, or do you intend to move away?

\section{ACTIVITIES}

People follow jobs. Consequently, in the 1940s and 1950s many people moved away from Appalachia. Then twenty or thirty years later, as job opportunities in the Appalachian region increased, many returned. Because many new people without Appalachian roots think this is a good place to live, they also have moved to the Appalachian region. (See next page.) 
On this map of the United States mark places your parents have lived because of their parents' jobs or their own jobs. Mark places your mother has lived with an $M$ and where your father has lived with an F. Write your name on places where you have lived.

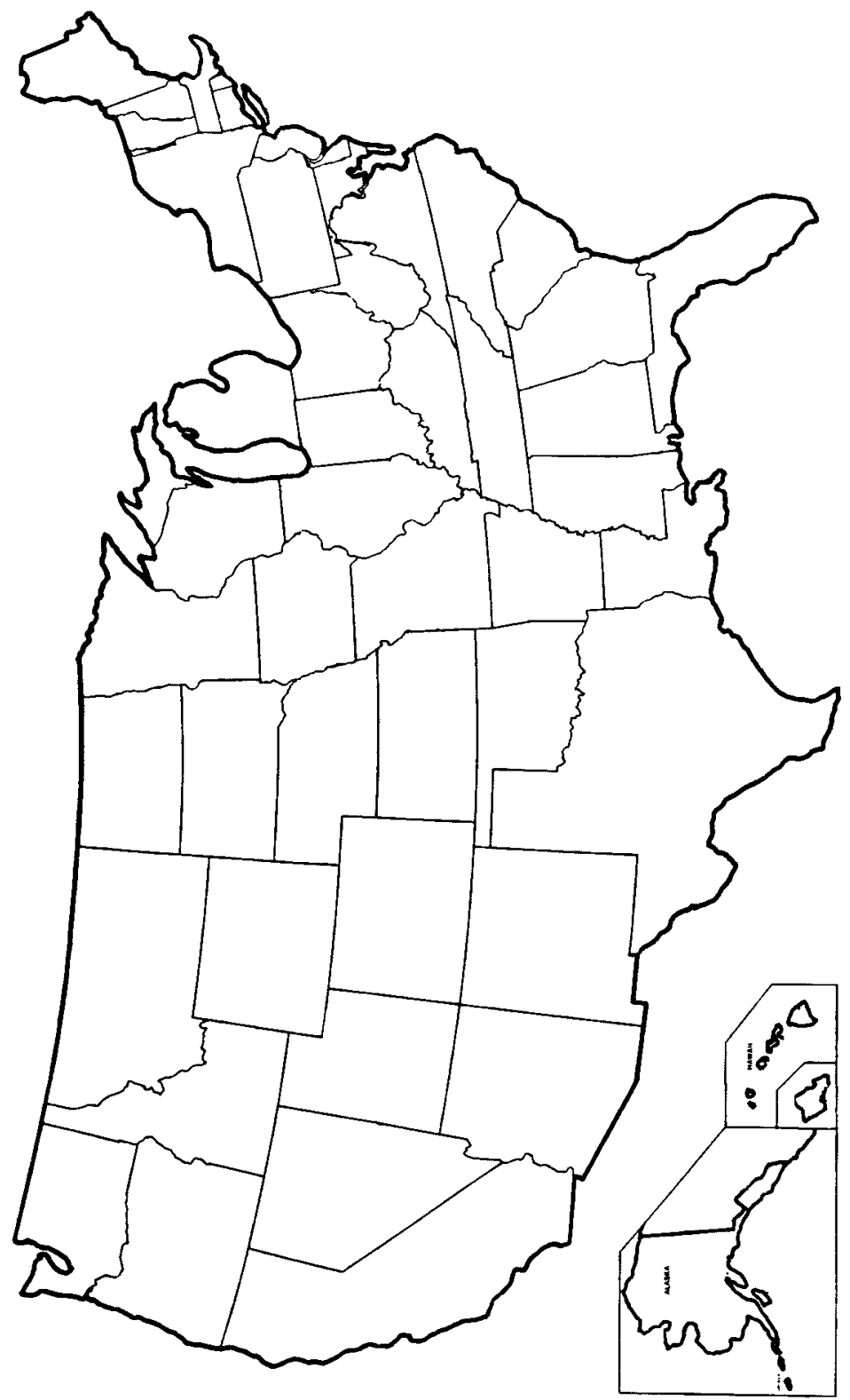




\section{CHAPTER 8}

\section{Roots and Wings: The Sense of Place in Appalachian Writing}

When Alex Haley published Roots, his family's history, the American public reacted enthusiastically. Millions of copies of the book were sold, and a television mini-series based on the book drew the largest viewing audience on record. Suddenly, as everyone tried to find out about his own roots, genealogy, the study of one's ancestry, became the rage. But the search for roots has long been a predominant theme in Appalachian literature.

All of us want to belong somewhere. We need to feel connected to each other, to the community, and to our surroundings. The fast pace of modern life disorients and isolates us from other people, even from our own families. Modern transportation with interstate highways, airplanes, cars, buses, and trains is a mixed blessing. It could be argued that our constant mobility is responsible for our sense of separation from each other and from our communities.

Throughout this book, we have seen Appalachian writers explore their personal histories. Their ties with a 
place and its people help them to define who they are.

At the heart of this sense of place lies love of the land. Responsibility and concern for the land are primary themes in the selections in this chapter. 


\section{WENDELL BERRY (1934 - ）}

Wendell Berry of Port Royal, Kentucky, is a teacher, writer, and farmer. He currently teaches English at his alma mater, the University of Kentucky. But farming and writing about farming are his primary occupations.

In his study of American culture and agriculture, The Unsettling of America (1977), Berry speaks eloquently of the state of the farm in America today and offers his vision of what might be done to foster responsible stewardship of the nation's land and resources. One of the nation's finest essayists, he gathered his published pieces in Recollected Essays (1981).

Wendell Berry's major contribution to the Appalachian literature is his verse. He has published many books of poetry including Farming: A Handbook, The Country of Marriage, The Broken Ground, and Openings. 


\section{The Strangers}

The voices of travelers on the hill road at dusk, calling down to me:

"Where are we? Where

does this road go?"

They have followed the ways

by which the country is forgot.

For them, places have changed

into their names, and vanished.

The names rustle in the foliage

by the roadside, furtive

as sparrows. My mind shifts

for whereabouts. Have I found them

in a country they have lost?

Are they lost in a country

I have found? How can they

learn where they are from me,

who have found myself here

after an expense of history

and labor six generations long?

How will they understand my speech

that holds this to be its place

and is conversant with its trees

and stones. We are lost

to each other. I think of changes

that have come without vision

or skill, a new world made

by the collision of particles.

Their blanched faces peer

from their height, waiting

an answer I know too well to speak.

I speak the words they do not know.

I stand like an Indian

before the alien ships. 
The Strangers

1. What are some of the changes mentioned in the poem?

2. Explain the comparison of the poet facing the strangers to an Indian standing before alien ships. 
492 The Sense of Place in Appalachian Writing

\section{HERMAN HASCAL GILES (1922 - )}

With a high school diploma earned in Big Stone Gap, Virginia, his birthplace, Herman Giles began his journalistic career as a sports writer for The Kingsport Times.

He wrote, edited, managed and published newspapers in Nashville and Louisville before retiring in 1980 as president and publisher of The Bristol Newspapers. He now devotes his time to writing fiction.

He has published over two hundred short stories and novels in popular magazines. One novel, Kansas Trail, has also been published in England and Norway.

\section{Man of the Land}

The wagon with its muddy wheels and unpainted frame creaked toward the scattered buildings of Boone Gap, the lazy high-hipped mule choosing the road without signal from the massive, black-haired man or the faded little woman who sat at his side on the wagon seat.

Mirtle Castle raised her pointed chin from the cup of her hand and looked at the man beside her. "Fight, fight, fight!" she scorned, angry because they were here. "That's all you're good for, Mort. And us with rich land goin' to waste."

Mort Castle chewed his corncob pipe to the corner of his 
wide mouth and answered around the stem, "Tonight we'll have twenty-thiry dollars, dependin' on who I can find that's got faith in Rob Scalf whuppin, me."

Mirtie let the conversation end in that way. She hoped Rob Scalf would whale the daylights out of him.

When they reached Jake Neel's General Store, Mort drew back on the reins, threw down the foot brake, and he and Mirtie climbed from the wagon.

"I can whup anything that walks, crawls, or flies," Mort Castle boasted to the loungers around the store. "And if you want to make yourself a few extra pennies, bet on me against Rob Scalf tonight."

While Mort looked around the faces to find one who denied his claim so he could place his bet, Mirtie slipped into the store.

"Howdy-do, Mirtie," Jake Neel greeted, peering intently from under his horn-rimmed spectacles. "Are you a-wantin' to buy somethin'?"

Mirtie pushed her shawl down around her shoulders and let her hair spill light into the dingy gloom of the store. "I reckon not, Jake."

Jake casually said, "You could buy lots of things with the money your land would bring."

"I could that, Jake." she replied. "I could get all the dishes you got, and some new furniture."

"You could even buy that house across the street there."

Mirtie's eyes drank in the neatness of white clapboards and green palings. There was grass in the yard and evergreens at each corner of the building. "It's a nice house," she said.

"And it's for sale," Jake beamed. "Now if you'd set a reasonable price on your farm, I know a feller who'd take it."

"That feller's name is Jake Neel, " Mirtie laughed. "We've argued about this before, time and again, Jake. But this time I'm sayin' maybe I'll sell."

"It's awful growed up," Jake said cautiously. "Feller can't walk over it for briars and locust sprouts."

From that approach Jake started making offers, and Mirtie shook her head at the first few ventures on Jake's sliding scale. 
"Give me a week to think it over, Jake," she concluded at last. "That ain't what I come for. Mort's fightin' Rob Scalf tonight and I want to bet you Rob will whip him." Mirtie said it all in one breath as if she wanted to rush through a task distasteful to her.

Jake hid his surprise. Without looking at her, he mused thoughtfully: "One day somebody's goin' to break Mort's neck."

"Sometimes," Mirtie replied, "I wish they would. I could maybe cure him from a broke neck, but I ain't ever saw a man with Mort's trouble cured."

"Mort has got a lot of wrong idees," Jake agreed solemnly. "I recollect when he was a young man and strong as an ox. All he ever talked about was fightin' John L. Sullivan and them fellers. 'Cause he never got to do that, Mort decided he wouldn't do nothin'. Mort is a man of the land and a man of the land has got to take his livin' from it. It's a shame with all that boundry your pa left you goin' to waste, too."

"Do you think Rob Scalf can whup him?" Mirtie asked as a reminder of her bet.

Jake went around the counter. "I'll bet you ten against five Mort whups Rob."

Mirtie dumped the contents of her carpet bag on the counter. There were only four dollars and seventy-three cents when she counted the small change, but Jake let the bet stand as it was.

Mort Castle's bouts had become as regular as a Saturday bath in Boone Gap, so everything was in order when Mirtie arrived at the big beech tree back of the town hall. Old men with beards, mothers with babies in their arms, and boys too young to be in the army formed a restless circle.

Squire Bellwood, official refree, limped toward Mirtie with a bundle of rags. His spindly legs were so cramped from rheumatism that he could do little but stand aside and wait for somebody to fall and then declare the man left standing the winner.

"Thought you'd never get here, Mirtie," Squire Bellwood 
wheezed. "Mort's mighty anxious to git started, but he won't let nobody wrap Rob's hands but you. I already got Mort's hands kivered."

Mirtie knew a few scraps of gingham left over from making dresses was little protection for a man's hands. Mort wouldn't fight without it, though. He said all fighters did it that way.

"You're a fine lookin' boy in that uniform, Rob," Mirtie said. "The army put some meat on your bones."

"Thanks, Mrs. Castle," Rob Scalf grinned. "I allow your old man's hankerin' to take a little meat off my bones."

Mirtie finished with one of Rob's hands and started on the other. "How long you home for, Rob?" she asked.

"Ten days. Then I reckon I'll be crossin' over."

Mirtie said, "If you see my boys Fred and Jack, tell 'em howdy."

"I'll tell 'em I whupped their old man," Rob called after her as she moved away.

Squire Bellwood hobbled forward, and motioned to Mort and Rob. They met in the center of the improved ring and shook hands.

"Rob," Squire Bellwood asked loudly, "have you any dislike for this man you're goin' to fight?"

Rob Scalf said, "No."

"Mort Castle, have you any dislike for Rob?"

Mort shook his head that he had none.

"As the law of this here town, I say it's a fair and legal fight all for fun," Squire Bellwood declared. "If either of you git kilt, it ain't nobody's fault. Now, light into it!"

Ten minutes later, Mort Castle was still trying to hit Rob Scalf. The tall, lithe soldier was no longer the clumsy farmer's boy who'd always walked like a plow and a team of horses were in front of him. He smashed Mort's nose, blackened his eyes, and cut his lips.

Mort made that last desperate charge which had carried down many mountain fighters. But Rob lifted a fist from his knee and flattened it on Mort's chin, and Mort went down and lay quiet. 
It was sundown by the time Mort and Mirtie drove out of Boone Gap. Mort had his pipe clenched tightly between his teeth, staring morosely at the mule's hoofs.

"You bet against me," Mort said presently.

"Yes," Mirtie replied softly. "I knowed if you lost we wouldn't have much to eat on until one of the boys sent us some money. I'd rather save their money for them."

"A woman ought to stand by her man."

At their door, Mort halted the wagon and let Mirtie out. He drove on and stabled the mule. When he came back he didn't say anything.

Next day, still silent, he took his rifle and went into the woods, brooding.

Mirtie was glad to see Enoch Redsoe, the mailman, pushing his way through the dry sedge below the house. Mirtie did not fear bad news from her boys; she'd know when something happened to Fred and Jack. Something faster than mails would tell her - something she could feel inside herself. Enoch handed Mirtie a thin, small envelope. The letter was the kind that came from overseas.

The news in Fred's letter was so good she wanted to keep it to herself for awhile. "Ma, I've rode a plane over enemy country forty-five times. When I make fifty trips I can come home. I ought to be there in a few months or so..."

Mirtie was still sitting by the window when Mort came home. He started to walk by her like she wasn't there.

"Fred's comin' home," Mirtie said quietly.

Mort stopped in his tracks, one big hobnailed shoe reaching for another step. For a moment he stood there, then he walked to the corner and put his rifle down. tie?"

Without turning around he said: "Is - is Fred all right, Mir-

"He ain't shot up none," Mirtie answered. She handed Mort the letter and he came close to the lamp on the window sill and read it standing up.

Afterwards, Mort sat in his hickory-bottom rocking chair near the fireplace and lit his pipe. Mirtie knew he missed his boys, though he usually tried to act like he didn't know they 
were gone. "Fred's goin' to be hurt when he gets home," Mirtie broke the stillness. "He's goin' to be hurt deep."

Mort replied proudly, "Fred can take care of hisself. He's a fightin' man. His pa's a fightin' man."

"His pa's a coward," Mirtie exclaimed, a touch of color rising in her cheeks. "When we was married you was aimin' to clear this land and make it a good farm. Once you started it, but one of them carnivals came to town and you spent the week fightin' in a show with a carnival man."

"I made thirty dollars," Mort defended stubbornly.

"It's easy to win fights if that's your callin'," Mirtie affirmed. "It takes an honest-to-goodness man to whup the land. The land whupped you, Mort. That's why I'm selling it."

Mort took his pipe from his mouth and stared at her. "Sellin' it!" he roared. "So Jake Neel has finally talked you into it!"

Mirtie's eyes flashed as she swung her gaze to Mort's ruddy face. "I' $m$ doin' it for Fred and Jack. They say they' re buildin' a new world. They are changin' for the better. I'm going to take the money I git from this place and buy'em a nice house in Boone Gap!"

Little knots of muscle bunched along the rim of Mort's jaw and he ground his pipe stem between his teeth. It seemed an eternity before he spoke again.

"Mirtie," he said at last, a gentleness in his voice which reminded her of his youth, "Don't sell this land!"

"It's no good to us, Mort."

Mirtie moved hurriedly away from the window and into the bedroom. Before she went to sleep, she saw Mort walk over to the window to stare out at the dark hills.

Later, a rosy glow against the window startled Mirtie awake. Still in her nightgown and barefooted, she rushed to the window and looked out on a raging field of fire.

Spiny locust sprouts down past the hollow road were being gulped away by the hungry blaze. The sedge brush below the house was already gone. In its place was a field of black stubble which left a smell pleasant to Mirtie's nose. 
At the far edge of the field she saw Mort's husky figure. He had the mule hitched to the bull-tongue plow which her father had stored in the smoke-house before he died. Mort had the check lines looped behind his neck so he could use both hands on the plow handles. Furrows of fresh, gray earth were being made by his plow and Mirtie could hear his deep booming voice above the crackle of the flames around him.

Mirtie slipped into her clothes and ran into the field. She crept around to the left where Mort couldn't see her. She could hear what he was saying now.

"Fire to a farmer is like steel knucks to a fighter," Mort roared at the straining mule. "This here land ain't for sale." Mort yelled. "Time spring gits here, corn will be a-sproutin' in the field. We are a fightin' family, mule. I can whup anything that walks, flies or crawls. And by Godfrey, I can whup the land!"

\section{Man of the Land}

1. After the fight, Mort tells Mirtie that a woman ought to stand by her man. Has she failed to do this? Explain.

2. Mirtie appears to be blessed with woman's intuition. Find evidence of this.

3. Mort is a man who loves to fight. How does Mirtie turn this love to a better advantage?

4. What prompts Mort to go out and "whup the land?" 


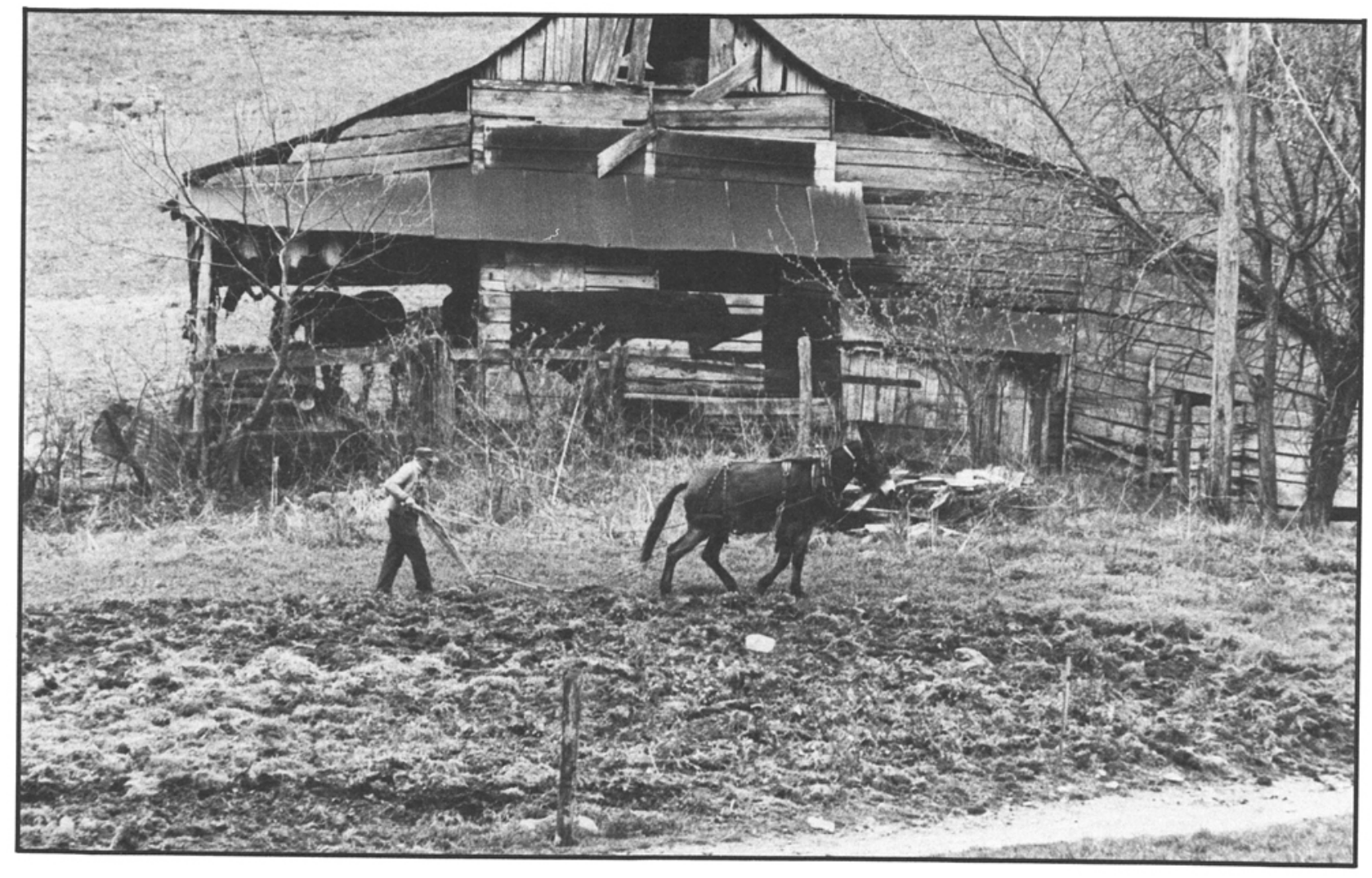




\section{JUDY ODOM (1942 - )}

Judy Odom grew up in Birmingham, Alabama, and lives in Johnson City, Tennessee, where she teaches English at Science Hill High School. She earned her B.A. degree from Birmingham Southern College; she was elected to Phi Beta Kappa there. She received her M.A. degree from Emory University.

During the summer of 1983 she participated in the Bennington College Writing Program in Vermont. In 1985 she received a Stokely Fellowship at the University of Tennessee. Her publications include short stories in Crescent Review, Homewords, Now and Then, and Mountain Laurel. Her short stories won the 1986 and 1987 Sherwood Anderson Awards.

\section{The Killing Jar}

When you first become a father, you feel so strong. I've got a son myself. I know. Matt's fourteen now; it won't be long till he's a man. He gets embarrassed if I talk about it, but I can still remember how he looked the minute he was born. I was Nancy's labor coach; I went through the delivery with her. I did my best to ease her through the pain.

I cried, you know. I couldn't help it. If you'd been there, you'd understand. Matthew looked so little and so fragile. I could've crushed his bones to powder between my index 
finger and my thumb. But helpless as he was, the first real breath he drew, he used it for a roaring challenge to the world. You should've seen him kick his legs and wave his arms around-like he could take life on and whip it there and then. I knew he had defeats ahead of him, and troubles; no father can protect his son from those. But I swore I'd try to see that Matthew held on to his fighting spirit. I promised myself I'd train him up a champion, win or lose.

The best I could, I've kept that promise, although God knows it's been hard sometimes. It can get so complicated, raising children. Other parents, they don't warn you. They just sit back and grin and wait for you to find out on your own.

I don't mean baby problems like the times they cry all night because they're teething or they've got the colic. Times like that can leave you worthless as a burnt-out light bulb for a litthe while, but they don't overload the power circuits in your soul. To get through teething or the colic, all you need's endurance. You walk the baby and you hold him warm against your stomach, and you use the simple medicines the doctor gives you for that simple kind of pain. Later on, the remedies don't come so easy. Later on, you have to watch him hurting and admit you don't know what the hell to do.

Just like last fall, when Matt first started high school. The kind of thing that happened then-that's what I mean. Ever since he was a little kid, he's lived for basketball. He played in the City Park and Recreation League from fourth grade on. So when he got to high school, naturally, he went out for the Bteam. That's what they call the freshman-sophomore squad. Well, it's a big school, and there's lots of competition. Matt didn't make the team.

The only thing he'd say to me was, "I don't want to talk about it." I tried to put my arm around his shoulders, but he dodged me and went charging upstairs to his room and shut the door. All I could do was stand there thinking how I'd like to wring that B-team coach's neck and then slam dunk his head.

'Course, you know I didn't do it. Nancy calmed me down. "It's Matt's problem. It's not yours," she said. "He'll handle it 
okay."

And she was right. He handled it. He handled it just fine. They needed a student manager for the varsity, and Matt decided he'd take on the job. He helped out all season during practice, and sometimes he worked the scoreboard at the games. He got to travel with the team. "lt's not as good as playing, Dad," he told me. "But I'm picking up some pointers from Coach Proctor and the guys. I'll try out again when I'm a sophomore. Coach says he bets I make it in another year."

Matt sure learned grace and style from somewhere. I wish I could take credit for it, but I can't. He figured out a way to lose and still come out a winner, and he did it on his own. I think he knows I would've tried to help him if he'd asked me. I hope he understands how proud I am he found the right direction all alone. He's still too young to notice that his independence makes me feel a little sad and lonesome. I don't mind the sadness, though; it's natural. It's a natural thing.

Every bullet needs a rifle to propel it toward its target; every rocket has to have its launching pad. If a father serves his proper function, he's bound to end up getting left behind.

I had to read this poem once in high school. I don't remember who it was that wrote it, and I don't remember what it's called. But this poet, he compared two lovers to a compassthe kind of compass that you draw with in geometry. He said the woman was the fixed foot; she stays steady in the center and helps the man to keep his circle true.

English never was my favorite subject, but that damn poem hit me hard. I'd just started dating Nancy, and I realized we could be like that if we stayed together. Even then, I knew I could depend on Nancy to anchor me and hold my circle firm.

I see now it's the same with sons and fathers. A father has to do that same thing for his son. He has to stay in one place, hardly moving, while his son goes out to form a brand new circle and create his own design.

A compass doesn't work unless its halves are joined together, but they have to stretch out separate from each other, too. Unless the son's allowed to reach his proper distance from 
the father, he can't accomplish anything.

That's why I should've let the boy alone about that business with the bug collection. Usually, I don't interfere in school work; that's a rule. Matt's a smart kid. Maybe too smart. I guess he takes that after Nancy. He gets his blonde hair and his stubbornness from me.

He likes history and English best, though learning anything comes easy for him. He wants to be a TV newsman like Dan Rather is-at least, that's what he's saying now. I don't discourage him. I know it's good to have your dreams. Soon as he meets a girl and wants to start a famiiy, he'll turn practical. I did. 'Most everybody does.

Sometimes I wonder if he reads too much. He's reading every minute he's awake, if he's not playing basketball. All that reading - that's what makes him ask so many questions. He worries about stuff that shouldn't matter to a boy his agethe kind of stuff nobody can do anything about. These days, it's children over there in Ethiopia. Last month, it was the Nazis and the way they slaughtered Jews. Matthew sees a wrong, he wants to right it. There's a lot about this life he doesn't understand.

Relax and have yourself a good time, boy, I want to tell him. Don't fret away your heat and brightness because you can't bring summer to a frozen world.

To tell the truth, I wouldn't change him, though. That ferocious energy he's got-it's like the lightning. You tremble at the power of it, and you fear the danger, but you can't help thinking that it's beautiful. You wish it could last longer than it does.

The minute he walked in that afternoon, I knew he was all fired up over something. He didn't even say hello or ask what I was doing home. He threw his books down on the kitchen counter, then he grabbed an apple and a glass of milk and headed for his room.

It was Friday, and I guess I had spring fever. On my way to work that morning, I'd noticed the forsythia in Mrs. Martin's yard next door. The sight of all those little yellow flowers made 
me restless for some reason. The branches curved so graceful, they made me think of how the line arcs out from my new casting rod. I closed up the body shop at noon and came on home.

We own this piece of land on Bear Claw Mountain. 1t's nothing fancy, just a rundown cabin and five acres by the lake. My daddy bought it in the forties for the taxes; he left it to me when he died five years ago. I thought we'd drive up there and stay the weekend. Nancy said she'd skip her gourmet cooking class on Saturday and come along. We had the car all packed. Then Matt came in, about as cheerful as a winter rain.

I told Nancy he could pick some other day to hide out in his room and stare at shadows. I wanted us to sit together in the sunshine and smell the wind and maybe hook a trout. He'd feel better once he saw the new grass sprouting and the new leaves shining red on all the maple trees.

So, I went upstairs to get him. I knocked, but when he didn't answer, I opened his door and walked on in. He was slouched down in his big chair, listening to his Walkman. That's why he didn't hear me knocking - he had those headphones on. His eyes were closed and he was tapping out the rhythm of the music on the chair arm. It must've been a real fast song.

For a minute, I stood looking at him. I was so close, he must've felt that I was there. "Hey, buddy." I touched him on the shoulder. "Let's go fishing."

He slipped off the headphones. I could hear the music. It sounded far away and strange, but still it was familiar. A few more seconds, and I might have recognized the tune.

"What?" he asked me. He punched a button and the music stopped. "What did you say?"

"Let's go fishing," I repeated. "I thought we'd go up to Bear Claw. Spend the night, you know. Maybe stay through Sunday if the fishing's good."

"Okay. Sure." He shrugged his shoulders like he didn't care one way or the other, but I saw the beginning of a smile. "Maybe I can catch some bugs up there. We have to do this bug collection for biology," he said. "Idon't like it, but I guess I have 
to do it if I want to keep an A. Maybe I'll punch holes in the jar lids. If I do that, the bugs won't die." The smile was getting bigger; it was spreading to his eyes.

"Good. That's fine," I told him, thinking everything was settled. "Well, get the lead out, boy," I grinned. "Your mother's waiting. Put some clothes in your backpack and get your butt out to the car."

He stood up like a spring uncoiling. Six more months, and he'll be taller than I am.

Nobody talked much on the drive to Bear Claw. Nancyshe's a quiet woman; she likes looking out the window at the trees and fields and houses rushing by. Matt just sprawled across the back seat and plugged into his Walkman. Glancing at him in the rearview mirror, I could almost see the music wrap itself around him like a blanket-or a cocoon. Before long, though, the highway got so twisted and so narrow, I couldn't look at anything except the road.

At least he didn't take his Walkman fishing. He put it on the kitchen table in the cabin while he rummaged through the cabinets for some empty jars. He found a couple and he brought those with us, but he left the Walkman there. Maybe he remembered from the last trip. Spring or winter-any season-the mountain wraps you in a music of its own.

We didn't catch a single fish that evening. We didn't try. Matt hadn't even brought his rod and reel down to the lake. We just sat there quiet and watched the daylight fade. Once, I pointed out a dragonfly. Matt nodded, but he didn't make a move to chase it. I didn't press him to.

There wasn't any wind to speak of, not enough to ruffle up the water. You could see the sky and clouds and trees reflected in the lake. Tossing in a hook and sinker would've been like throwing rocks straight at a mirror. I half believed the lake would shatter into pieces if I did. All afternoon, my casting rod stayed propped against a tree stump, next to Matt's two empty jars.

Before the sun was hardly down, we saw the first star shining. By then, the pines across the lake had blurred into a wall 
of dark blue shadows, so we collected all our gear and climbed back up the hill.

Nights turn chilly on the mountain, even in the springtime. I was glad to have my family warm inside the cabin, with the smell of coffee brewing and supper cooking on the stove.

The next morning, Matt and I were at the lake again by seven. Mist was rising off the water, and the dew soaked through my tennis shoes. Within an hour, I had hooked three trout and one fine catfish, and Matt had captured half a dozen bugs. He brought them to me for inspection; I could barely see them for the grass and twigs he'd stuffed inside the jar.

"What's that for?" I asked him, but I knew already.

"Food," he said. "They have to eat. They need some food." He set the jar down slow and careful on the ground between us and locked his hands around his knees.

Somewhere behind us in the woods, a bird was singing. I wish I could've told Matt what it was. My daddy knew the call of every wild thing on the mountain; he'd have named that bird by listening to its song. He tried to teach me, but I never bothered learning. It didn't seem important at the time. I picked the jar up off the grass and held it balanced in my palm.

"That's a pretty one right there." I pointed at a little pale green insect that was darting back and forth inside the jar and slamming up against the glass. It had a narrow, rod-shaped body and long, transparent wings. Flying free, it would've been real graceful; it would've danced across the air.

"You giving these guys one last meal before the execution?" I asked, knowing that it was a cruel thing to say. "You have to kill them, don't you? Pin them on a board and write their scientific names and everything?" I set the jar back on the ground.

Matt wouldn't look at me. I didn't blame him. He pulled up a wad of grass and flung it scattering against the wind. "Yeah," he nodded finally. "That's right. I have to kill them. Mrs. Burke said use a killing jar."

"A killing jar?" I repeated it like some fool kid who's got a lesson he can't quite understand.. "What the hell's a killing jar?" "You put your insects in an air-tight jar," Matt said. "No 
holes in the lid. You soak a cotton ball in polish remover-like Mom puts on her fingernails, you know?" He didn't wait for me to answer; he went right on explaining. He wasn't even talking to me, really. He just had to get it said. "And then you drop the cotton in the jar and screw the lid on. That's it," he said. "That's what you do. She says it only takes a second. The poison's quick. There's poison in the fumes. It's painless-so Mrs. Burke says." Matthew's voice rasped like a file on metal. "I'm not sure I can do it, Daddy. I don't think I can."

"Why not?" I was losing patience with him. Nobody normal-boy or man-would give one holy damn about a bug. "They don't last but a season anyway," I argued. "If they don't get snapped up by a bird or some old bullfrog, they freeze to death the first cold spell." I flicked my wrist and watched the motion ripple through my fishing rod. The line hummed out across the water and splashed into the patch of sunlight I was aiming for.

Matt had his lower lip poked out that stubborn way he does sometimes. "I know that," he growled. "I know they don't live long. They' re not supposed to. I mean-you know-it's the food chain. A bird kills insects 'cause he needs the food. Then something bigger comes along - a cat or something - and he eats the bird. That's all right. It's sort of neat, you know?"

"Matt, if they're dead, they' re dead," I tried to reason with him. "Whoever kills them-you or some damn bird-it doesn't-"

"I don't like killing for no reason," he insisted. "It's a bad thing, Daddy. Animals don't do it. I won't either. I don't care if I fail biology." He grabbed the jar and held it tight in both his hands. Before I had the time to say another word, he opened it and turned it upside down. Quick as lightning, every bug he had was gone.

The little green one leaped straight up, it seemed like. I watched it dancing till the sun got in my eyes.

"I don't understand you, boy," I said and reeled my line in. I didn't feel like fishing any more. "Your school work-that's the most important thing there is. A good grade's worth 50,000 
bugs."

Matt wouldn't answer. He jumped to his feet and stalked off by himself. I figured he'd come back when he got hungry, so I didn't try to stop him. I stared out at the water and let him walk away.

About noon, I started for the cabin. Sure enough, I met him halfway up the hill. He said he'd walked the shore full circle. That must be close to seven miles.

He told me about a water snake he'd seen, and a mother rabbit with two babies. We didn't mention bugs again.

Matt helped me clean the fish like always. I was surprised he did. Nancy fried the trout in cornmeal, and we put the catfish in the freezer for another day. We use every fish I catch. My daddy taught me that much, anyhow.

After we finished eating, Matt and Nancy decided they'd hike to the top of Bear Claw. At the summit, there's a meadow, and it's beautiful in spring - wild flowers growing everywhere and long grass rippling in the wind. Any place you look, there's other mountains. You're standing at the center of a magic circle, protected by a solid ring of dark blue flames.

If I had the cash, I'd buy that land tomorrow and build myself a house up there.

I told Matt and Nancy to go on without me, that I'd rather take a nap than make the climb. Nancy raised her eyebrowsshe knows how I am about that meadow-but she didn't question me. She just hustled Matt on out the door.

I stood on the back porch till the pine trees closed around them. Matt was whistling; I could hear him for a long time after they were out of sight.

With my family gone, the cabin felt too empty. I tried to sleep, but couldn't, so I strolled down to the lake again. Matt's empty jars were lying in the grass right where he'd left them. I stretched out on the ground and propped my chin up in my hands. Then I saw the ladybug in front of my left elbow. She was balanced on a grass blade like a diver on a diving board.

"'Ladybug, ladybug,/ Fly away home." Whispering to her like a kid, I sat up slowly and felt around until my right hand 
touched a jar. Her wings didn't even flutter; she didn't pay me any mind. "Your house is on fire/ Your children all gone.'" I finished up the rhyme and waited, but she didn't move.

"Well," I said a little louder, "you've had your warning, ladybug." I flicked the grass blade with my finger and sent her diving into glass.

That whole long afternoon, I roamed the lake shore like a big game hunter, using one jar for a trap and the other for a cage. I collected two big shiny dark green beetles and a dragonfly, several ants of different sizes and one fat black and yellow bumblebee. The catch that made me proudest took a lot of skill and quickness. In the stream that feeds into the lake, I came across a bunch of Jesus bugs. Daddy used to call them that because they walk on water. I know it's sacrilegious, but l've never heard them called by any other name. Well, they skim along so fast, it's hard to trap one. You think you've got it in your jar, but then you blink one time and zip! It's gone. Finally, I had to wade out in the stream up to my knees.

Mountain water's liquid ice in springtime. I squished back to the cabin and changed into dry socks and pants and shoes. I put on a heavy sweater, too. Then I dragged a rocking chair out on the front porch, so I could sit in comfort and watch the sun go down.

I was feeling warm again, and happy 'cause l'd solved Matt's problem. Thanks to me, my boy could satisfy his conscience and his teacher both. Soon as he and Nancy came back from the meadow, I'd explain. Matt and I could work together. We'd do this project as a team. Smiling to myself, I rocked a little faster in my rocking chair.

I'd tell him that I'd trap the bugs he needed. I would operate the killing jar. Once the bugs were dead, it shouldn't bother Matt to classify them. He could pin each carcass to the board and label each one with its fancy scientific name.

When Matt was eight years old, we won the Cub Scout Racer Derby. We built a model racing car out of a block of wood they gave us and a regulation set of wheels. I still remember how we cheered and how Matt hugged me when 
our car rolled in first across the finish line.

These days, there's not much left that we can build together. Matt's at the age when young men start to do their building on their own. Every boy has got to make himself a place that he can live in. My daddy had to watch me do it, and it's my turn now to watch my son. I have to stand aside and see the walls get higher, and hope to find a door somewhere that's open to me every now and then.

I looked at my watch, but it was hard to read the numbers. Where the hell had Matt and Nancy got to, anyway? They both knew better than to try and feel their way down Bear Claw in the dark.

The sky had turned soft purple like it does clear evenings after sundown, just before the light's completely gone. All the birds had settled for the night and stopped their singing. Every leaf and branch and blade of grass was resting, absolutely still. The land stretched out around me, hushed and waiting. I realized I had stopped rocking; I was waiting, too.

Then I heard Matt's whistle, and footsteps padding down the slope.

"Ben? Hey, Ben-where are you?" It was Nancy calling. I went inside to build a fire.

Matt didn't act real pleased about my plan when I explained it to him after supper. He just frowned and shrugged and said he guessed it was okay. Until bedtime, he sat by the fire and read some book he'd brought along and listened to his Walkman. He didn't say another word except good night.

Next day, I didn't fish-I hunted. Matt had said he needed thirty different bugs. By two o'clock, I'd captured thirty-five and filled three empty jars. Nancy found a praying mantis on the back door screen. We gave him a fourth jar to himself. I didn't know but what he fed on other insects, and I didn't want to see my day's work disappear.

We didn't have the right equipment with us at the cabin; we'd have to make the killing jar when we got back to town. I decided that l'd do it fast-that very night-and get it over with. By three o'clock, we'd packed the car and started home. 
Matt had the four jars lined up on the seat beside him. I told him to be sure and grab them if I had to stop or swerve real sudden. You never know what's going to happen on that narrow mountain road.

Stores are open here in town from one till six on Sunday, so I went by K-Mart. Matt stayed in the car with Nancy; he said anything I bought would do. I picked out two small cork bulletin boards for him to mount the insects on. Then I found a pack of little self-stick labels and a plastic box of pins. Matt would have to get some books on classifying insects from the library at school.

At home, we set the jars on the kitchen counter until we could unload the car. I put the K-Mart sack down on the table and told Matt he could carry in his backpack and the suitcase while I brought in the cooler and the box of food we hadn't used. Sharing out the work that way, it didn't take us long.

Nancy found the cotton balls and the polish remover for me, and an empty jar with no holes in the lid. I thought she looked a little bit uneasy when she brought them in. And sure enough, she didn't like it either. "Ben, you can't do that in here," she said. "Not in my kitchen." Her face was turning red.

I said okay and hugged her. Then I took everything into the den.

The praying mantis can go first, I thought, 'cause he's so big and ugly. Being careful not to give him space enough to make a jump for freedom, I transferred him into the killing jar. I soaked some cotton with the polish remover. The alcohol evaporating made my fingers cold. I loosened the top of the jar and raised it just a little to push the cotton in.

Mrs. Burke sure spoke the truth when she told Matt it wouldn't take a minute. I forced myself to be a man and watch, and it was over in a breath or two. But that was long enough to show me Mrs. Burke had lied about one thing. She'd said the killing jar was painless. Well, it wasn't. In those few seconds, I saw agony.

Dear Lord, I thought. Matt was right. I should've listened to him. This is killing for no reason. A good grade's nothing 
but a letter on a piece of paper. It's not worth one creature's suffering. boy."

"Matt!" I yelled real loud. "Come on in here and help me,

He's a good kid, used to doing what his daddy tells him, even if he disagrees. Sooner than I had expected, he was standing in the door. "Come on, son," I grinned. "Let's take these jars out in the yard." He raised his eyebrows at me just like Nancy, but he did what I said.

Outside, we knelt down in the grass together. "I killed your praying mantis, son," I said. "I'm sorry."

Matt looked at me like I was crazy. He still didn't understand. I laughed and shook his arm the way I do some mornings when he won't wake up for school. "Well, get the lead out, boy," I told him. "We can't turn these guys loose until you open up the jars."

"Thanks, Daddy. Thanks a lot," he said. Smiling as bright as sunrise, he offered me a jar. And, quicker than it takes to tell it, we released our prisoners in the grass.

We walked back to the house together and we climbed the porch steps side by side. Then Matt stopped and held the screen door open for me. I looked at him and smiled; he gave a little bow.

"Thank you, Matthew." I said it formal, like it was some kind of password. He nodded once and let me walk on in.

\section{The Killing Jar}

1. This story is told from the father's point of view. What attitudes and emotions might have been revealed if the son had told the story?

2. The father feels pride in his son. Find evidence of this in the story.

3. What does the father do to establish a bond of 
understanding with his son? What prompts the father to do what he does?

4. Explain the following statement: "If a father serves his proper function, he is bound to end up getting left behind."

5. What other title might be appropriate for this story? 
514 The Sense of Place in Appalachian Writing

\section{RITA QUILLEN (1954 - )}

Rita Quillen, a fifth-generation Appalachian, has lived her entire life in Hiltons, Virginia.

Sheattended Mountain Empire Community Collegebefore earning a B.S. and an M.A. in English from East Tennessee State University. Her master's thesis examined four other Appalachian poets included in this anthology-Jeff Daniel Marion, Fred Chappell, Robert Morgan, and Jim Wayne Miller. She also completed a bibliography of Appalachian poets which was published in The Appalachian Journal. A chapbook of her poetry, October Dusk, has been published by Seven Buffaloes Press.

"The Good Life" is a bittersweet look at life on the farm. Although it is a trying life, lacking in some modern comforts, the speaker decides that leaving would be impossible. The last line "I cannot leave; I cannot go away" is a line from James Still's poem "Heritage," echoing his sentiment of an attachment to a place that is too powerful to overcome. 
The Good Life (for Fred Chappell)

Tobacco teepees stand desolate after the massacre.

Weary sunflowers look like women in yellow bonnets nodding in the last hot dose of August sun.

Across the field my husband works with bare back and arms splitting and stacking oak and hickory, building a fort against the winter he already hears in the trees.

This sad but noble scene is not the whole story.

The horse cut his leg on a John Deere mowing machine.

The bull died with a fever caught on the road.

Tomatoes rot in piles; weeds choke the roses. This trip is not all that divine.

My shadow is not my partner in the row. It has a more modern mind, longing for dishwashers garbage disposal sidewalks for Bandolino shoes. 
516 The Sense of Place in Appalachian Writing

But the daydreams will pass like the summer.

Five generations of headstones, protecting their interests, huddle silently

in the field by the big oak.

They do not have to speak.

I already know:

I cannot leave; I cannot go away.

\section{The Good Life}

1. What does "the good life" mean to you?

2. Explain the line "My shadow is not my partner in the row."

3. Locate the metaphors and the similes in the poem, and comment on their aptness for the context.

4. What reason does the poet give for her inability to leave the land? Do you understand this reason? 


\section{JAMES STILL (1906 - )}

James Still, who was born in Double Creek, Alabama, has been called "the psalmist of the mountains." A 1929 graduate of Lincoln Memorial University, Still earned an M.A. at Vanderbilt University in 1930. He has lived since 1939 in an old log house on Dead Mare Branch near the Hindman Settlement School in Kentucky. Before devoting himself to writing full time, Mr. Still was the librarian at the settlement school, and he also taught for ten years at Morehead State University.

He has published poetry, short stories, books for children, and novels. His short stories have been anthologized in such collections as the Best American Short Stories and the 0. Henry Memorial Prize Stories. Mr. Still is also a frequent comentator on National Public Radio.

When James Still turned 80 on July 16, 1980, the Hindman Settlement School threw a party to honor the man and his work. Several hundred people gathered from all over the country to pay tribute to one of the Appalachian region's finest authors.

"Heritage" expresses a great love for the mountains and an unbreakable bond with them. 


\section{Heritage}

I shall not leave these prisoning hills Though they topple their barren heads to level earth And the forests slide uprooted out of the sky. Though the waters of Troublesome, of Trace Fork, Of Sand Lick rise in a single body to glean the valleys,

To drown lush pennyroyal, to unravel rail fences; Though the sun-ball breaks the ridges into dust And burns its strength into the blistered rock I cannot leave. I cannot go away.

Being of these hills, being one with the fox Stealing into the shadows, one with the new-born foal,

The lumbering ox drawing green beech logs to mill, One with the destined feet of man climbing and descending, And one with death rising to bloom again, I cannot go.

Being of these hills, I cannot pass beyond.

\section{Heritage}

1. Most people desire to leave something which imprisons them. The speaker in this poem says he cannot leave. Do you understand his reason? Explain.

2. Describe the poet's feelings of oneness with nature. 


\section{COMPOSITION TOPICS}

1. Think of a time in your life when you have witnessed or experienced an incident that showed commitment to an idea, a person, or a place as the selections in this chapter do. Write a narrative about the incident. You may use your imagination to improve or embellish the story.

2. As the poets in this chapter have done, describe in poetry or prose a place you love. Use sensory imagery to make the description vivid.

\section{ACTIVITIES}

In a few years you will leave your parents and begin you own home.

When you have your own home, what are some family traditions that you want to continue?

What are some family values that you also want to make a part of your home?

When you begin your home, what will you leave behind?

Your book now contains your family in the past and as it has changed through the years. Because you represent your family's continuity, you are the major character in your book. End your book with your autobiography. Be sure to include:

1. Birth date and place

2. Name and reason your parents selected your name

3. Parents' names

4. Names of brothers and sisters 
5. Schools attended

6. Places lived and reason you lived there

7. Person or persons who have influenced you

8. Memorable experiences including your earliest memory

9. Important friendships

10. Jobs you've had

11. Plans for the future 
This page intentionally left blank 
This page intentionally left blank 


\section{Acknowledgments}

Grateful acknowledgement is made to the following for permission to reprint previously published material:

James Agee. From A Death in the Family, pp. 214-227, by James Agee. Copyright (ㄷ 1957 by the James Agee Trust. Copyright renewed $\odot 1985$ by Mia Agee. Reprinted by permission of Grosset \& Dunlap, Inc.

Lisa Alther. From Kinflicks. Copyright @ 1975 by Lisa Alther. Reprinted by permission of Alfred A. Knopf, Inc.

Clarence Ashley. "Ballad of Claude Allen," written and sung by Clarence Ashley on Folkways Records FA/2355 NYC.

Wendell Berry. "The Strangers" from The Country Of Marriage. Copyright (C) 1972 by Wendell Berry. Reprinted by permission of Harcourt, Brace, Jovanovich, Inc.

Kathryn Stripling Byer. "Wide Open, These Gates" from The Girl in the Midst of Harvest. Copyright (C) 1986. Reprinted by permission of Texas Tech University Press.

Edward Cabbell. "Appalachia: An Old Man's Dream Deferred" from Now and Then, Vol. 3, No. 1, Winter, 1986. East Tennessee State University. Reprinted by permission of the author and Now and Then.

Jo Carson. "People Pieces: My Brother Estes" from The Appalachian Journal, 1983. Copyright (C) 1983 Appalachian Journal. Reprinted by permission of the publisher.

A. P. Carter. "Single Girl, Married Girl." Copyright @ 1927 by Peer International Corporation. Copyright renewed. All rights reserved. Used by permission. 
Harry Caudill. "The Mountain, the Miner, and the Lord." Copyright $\odot 1980$ by the University Press of Kentucky. Reprinted by permission of the publisher.

Fred Chappell. "Firewater" from Midquest. Reprinted by permission of Louisiana State University Press. "My Grandmother Washes Her Vessels" from River, Copyright (C) 1975. Reprinted by permission of Louisiana State University Press.

Richard Chase. "Cat 'n Mouse" from The Jack Tales, by Richard Chase, Copyright (C) 1943 and Copyright renewed (C) 1971 by Richard Chase. Reprinted by permission of Houghton Mifflin Company.

Alan Cheuse. "Tripping the Lights Fantastic" from the Boston Globe Magazine May 29, 1983. Reprinted by kind permission of the author.

Lou V. Crabtree. "Homer Snake" from Sweet Hollow, Copyright 두 1984. Reprinted by permission of Lousiana State University Press.

Borden Deal. "Antaeus" Copyright (C) 1961 by Southern Methodist University Press. Used by permission of the Borden Deal Family.

Victor Depta. "TVA" from Laurel Review, Vol. 15, Winter, 1981, p. 52. Used by permission of West Virginia Wesleyan College.

Wilma Dykeman. "Chapter 5, pp. 151-162" from Return The Innocent Earth. Copyright (C) 1973 by Wilma Dykeman. Reprinted by permission of Holt, Rinehart, and Winston, Publishers.

John Ehle. "Chapter 13, pp. 173-186" from The Road. Copyright $\odot 1967$ by John Ehle. Reprinted by permission of Harper \& Row, Publishers, Inc.

Herman Hascal Giles. "Man of the Land" from The Watauga Review, Vol. 2, No. 1, 1968. Reprinted by kind permission of the author.

Richard Hague. "In the Woods Beyond the Coalfields" from Ripening. Reprinted by permission of the Ohio State University Press, copyright (C) 1984.

Mildred Haun. From The Hawk's Done Gone. Copyright (C 1968 by Mildred Haun. Reprinted by permission of Vanderbilt University Press.

Edwin Hoffman. "Strippers, No!" from The Fighting Mountaineers. Copyright (C) 1979 by Edwin D. Hoffman. Reprinted by permission of Houghton Mifflin Company.

Myles Horton. Interview with Sojourners. Reprinted by permission of Sojourners, Box 29272, Washington, D.C. 20017

Lee Howard. "The Last Unmined Vein" from The Unmined Vein. Copyright (C) 1980 by Lee Howard and Anemone Press. Reprinted by permission of author and publisher.

Horace Kephart. Condensed with permission of Macmillan Publishing Company from Our Southern Highlanders by Horace Kephart. Copyright (C) 1922 
by Macmillan Publishing Company, renewed 1950 by Laura M. Kephart.

George Ella Lyon. "Stripped" from Appalachian Journal. Copyright $(1981$. Reprinted by permission of the author and the Appalachian Journal.

Jeff Daniel Marion. "Ebbing and Flowing Spring." Reprinted by kind permission of the author.

Alice Marriott. "Tsali of the Cherokees" by Norah Roper as told to Alice Marriott from American Indian Mythology by Alice Marriott and Carol K. Rachlin. Copyright $(\odot 1968$ by Alice Marriott and Carol K. Rachlin. Reprinted by permission of Harper \& Row Publishers, Inc.

Bobbie Ann Mason. "Nancy Culpepper" (pp. 179-195) from Shiloh and Other Stories. Appeared originally in New Yorker. Copyright $\odot 1982$ by Bobbie Ann Mason. Reprinted by permission of Harper \& Row Publishers, Inc.

Jim Wayne Miller. "The Brier Losing Touch With His Traditions" and "Turn Your Radio On" from The Mountains Have Come Closer. Copyright $\odot 1980$ by Appalachian Consortium Press. "Beginning, Ending" from The Small Farm, Vol. 11 and 12. All reprinted by kind permission of the author.

Robert Morgan. "Bean Money" from Groundwork. Reprinted by permission of Gnomon Press, copyright (2) 1979.

Gurney Norman. "A Correspondence" from Kinfolks, The Wilgus Stories. Copyright $\odot 1977$ by Gurney Norman. Reprinted by permission of Gnomon Press.

Judy Odom. "The Killing Jar." Reprinted by kind permission of the author. Rita Quillen. "The Good Life." Copyright (O) 1984 Appalachian Joumal. All rights reserved. Reprinted by kind permission of the author and Appalachian Journal.

Jean Ritchie. From Singing Family of the Cumberlands by Jean Ritchie. Geordie Music Publishing Company. 7A Locust Ave., Port Washington, NY 11050.

Ron Short. From South of the Mountain, Act II. Copyright $\odot 1985$ Roadside Theater/Appalshop. Reprinted by kind permission of the author and Roadside Theater.

Lee Smith. "Saint Paul" from Cakewalk. Copyright @ 1981 by Lee Smith. Reprinted by permission of The Putnam Publishing Group.

Bernard Stallard. "The Writing Spider" from Appalachian Summer. Copyright $(0) 1967$. Reprinted by kind permission of the author.

James Still. "Heritage," Copyright $\odot$ by James Still, and excerpt from River of Earth.Copyright $\odot$ University Press of Kentucky. Reprinted by kind permission of the author.

James Stokely. "Molly Mooneyham" from The Small Farm, Vol. 7-8, 1978. 
East Tennessee Printing Company. Reprinted by kind permission of Wilma Dykeman Stokely and the publisher.

Jesse Stuart. From Daughter of the Legend and "Split Cherry Tree." Reprinted by permission of the Jesse Stuart Foundation.

Marilou Bonham Thompson. "Genesis" and "Where Mountain and Atom Meet" from Abiding Appalachia, Where Mountain and Atom Meet. Copyright (C) 1980 by Marilou Bonham Thompson. Reprinted by permission of St. Luke's Press.

Merle Travis. "Nine Pound Hammer." Copyright $\odot 1947$ by American Music, Inc. Copyright renewed and assigned to Unichappell Music, Inc., and Elvis Presley Music. All rights administered by Unichappell Music, Inc. International copyright secured. All rights reserved. Used by permission.

Robert Penn Warren. "Sitting on a Farm Lawn on a Sunday Afternoon" from Rumors Verified: Poems 1979-1980. Reprinted by permission of Random House, Inc., and Alfred A. Knopf, Inc.

Don West. "Harlan Portraits" from In a Land of Plenty. Reprinted by kind permission of the author.

Eliot Wigginton, ed. From Foxfire 3. Copyright $(C 1973,1974$ by The Foxfire Fund, Inc. Reprinted by permission of Doubleday \& Company, Inc.

Cratis Williams. "Dialect and Speech." Used by permission of the Center for Appalachian Studies at Appalachian State University, Boone, NC.

Thomas Wolfe. "Part IV: The Brother" (pp. 29-38) from The Hills Beyond. Copyright (C 1935, 1936, 1937, 1939, and 1941 by Maxwell Perkins as executor. Reprinted by permission of Harper \& Row Publishers, Inc. 


\section{Suggested Bibliography}

\section{AUDIOVISUAL MATERIALS}

Agee. Academy Award nominee documentary on life of James Agee. $16 \mathrm{~mm}$ aud videotape. James Agee Film Project Library, Box 315, Franklin Lakes, NJ 07417.

Appalachian Writers. $30 \mathrm{~min}$. films on Fred Chappell, Jeff Daniel Marion, Jim Wayne Miller, James Still. Children's Museum of Oak Ridge, Regional Appalachian Center, Education Division, 461 West Outer Drive, Oak Ridge, TN 37830 .

Cassette tape: James Goode. " Coalmining Families." Coalmining in the Cumberland, Feb. 1984. Children's Museum of Oak Ridge, Regional Appalachian Center, Education Division, 461 West Outer Drive, Oak Ridge, TN 37830.

The Electric Valley (portrait of TVA) on videotape or 16mm. James Agee Film Project Library, Box 315, Franklin Lakes, NJ 07417.

I Have A Place. Poetry of Jim Wayne Miller. $28 \mathrm{~min}$. videocassette. Western Kentucky University, Media Resources Center, Bowling Green, KY 42101.

\section{SELECTED BIBLIOGRAPHY}

Arnow, Harriette. The Dollmaker. Macmillan Publishing Company, 1954.

Arnow, Harriette. Seedtime on the Cumberland, 1960. Lexington: Reprinted by the University Press of Kentucky, 1983.

Blair, Walter. Natize American Humor. Scranton, PA: Chandler Publishing Co., 1960. 
Burton, Thomas. Some Ballad Folks. Boone, NC: Appalachian Consortium Press, 1978.

Carawan, Guy and Candy. Voices from the Mountains: Life and Struggle in the Appalachian South. Champaign: University of Illinois Press, 1982.

Caudill, Harry. Night Comes to the Cumberlands. Boston: Little, Brown, and Co., Inc., 1962.

Egerton, John. Generations: An American Family. Lexington: University Press of Kentucky, 1983.

Eller, Ronald. Miners, Millhands, and Mountaineers: Industrialization of the Appalachian South, 1880-1930. Knoxville: University of Tennessee Press, 1982.

Fox, John, Jr. The Little Shepherd of Kingdom Come. New York: Grosset \& Dunlap, 1931.

Fox, John, Jr. The Trail of the Lonesome Pine. 1908. Lexington: Reprinted by the University Press of Kentucky, 1984.

Gaventa, John. Power and Powerlessness: Quiescence and Rebellion in an Appalachian Valley. Urbana, IL: University of Illinois Press, 1980.

Goode, James B. Poets of Darkness. Jackson, Miss.: University Press of Mississippi, 1981.

Green, Archie. Only a Miner: Studies in Recorded Coal-Mining Songs. Champaign, IL: University of Illinois Press, 1972.

Higgs Robert J., and Manning, Ambrose, eds. Voices from the Hills: Selected Readings of Southern Appalachia. New York: Fredrick Ungar Publishing Co. in cooperation with Appalachian Consortium Press, 1975.

High, Ellesa Clay. Past Titan Rock: Journey Into an Appalachian Valley. Lexington: University Press of Kentucky, 1984.

Hornbuckle, Jim, and French, Lawrence, eds. The Cherokee Perspective: Written by Eastern Cherokees. Boone, NC: Appalachian Consortium Press, 1981.

Irwin, John Rice. Musical Instruments of the Southern Appalachian Mountains. Norris, TN: Museum of Appalachia Press, 1979.

Jolley, Harley E. Blue Ridge Parkway: The First Fifty Years. Boone, NC: Appalachian Consortium Press, 1985.

Joyce, Jane Wilson. The Quilt Poems. New Market, TN: Mill Springs Press, 1984.

Lyon, George Ella. Mountain. Hartford, CT: Andrew Mountain Press, 1983.

Marion, Jeff Daniel. Out in the Country, Back Home. Winston-Salem, NC: The Jackpine Press, 1976.

McCarthy, Cormac. The Orchard Keeper. New York: Random House, 1965. 
Miles, Emma Bell. The Spirit of the Mountains. 1905. Knoxville, TN: Reprinted by the University of Tennessee Press, 1975.

Miller, Jim Wayne, ed. I Have a Place. Pippa Passes, KY: Alice Lloyd College, 1981.

Miller, Jim Wayne. Reading, Writing, and Region: A Checklist, Purchase Guide and Directory for School and Communities Libraries. Boone, NC: Appalachian Consortium Press, 1980.

Montell, William Lynwood. The Saga of Coe Ridge: A Study in Oral History. Knoxville: University of Tennessee Press, 1970.

Murray, Ken. A Portrait of Appalachia. Boone, NC: Appalachian Consortium Press, 1985.

Norman, Gurney. Divine Rights Trip: A Folktale. New York: Dial Press, 1972.

Page, Linda, and Wigginton, Eliot, eds. Aunt Arie: A Foxfire Portrait. New York: E.P. Dutton, Inc., 1983.

Roberts, Elizabeth Madox. The Time of Man. 1926. Lexington: Reprinted by the University of Kentucky Press, 1982.

Shapiro, Henry. Appalachia on Our Mind. Chapel Hill: University of North Carolina Press, 1978.

Slone, Verna Mae. What My Heart Wants To Tell. Washington, D.C.: New Republic Books, 1979.

Smith, Lee. Oral History. New York: G.P. Putnam's Sons, 1983.

Walls, David, and Stephenson, John. Appalachia in the Sixties. Lexington: University Press of Kentucky, 1972.

Weller, Jack. Yesterday's People: Life in Contemporary Appalachia. Lexington: University of Kentucky Press, 1965.

West, John Foster. This Proud Land: The Blue Ridge Mountains. Photographs by Bruce Roberts. Charlotte, NC: McNally and Loften, 1974.

West, John Foster. Time Was. Random House, 1965. Re-issued Boone, NC: Folkways Press (Drawer 1834), 1977.

Whisnant, David. All That is Native is Fine: The Politics of Culture in an American Region.. Chapel Hill, NC: University of North Carolina Press, 1983.

Whisnant, David. Modernizing the Mountaineer. Boone, NC: Appalachian Consortium Press, 1980.

Wolfe, Thomas. You Can't Go Home Again. New York: Harper \& Row Publishers, Inc., Perennial Library Edition, 1973. 